\title{
Large-scale plantations, bioenergy developments and land use change in Indonesia
}

Anne Casson

Yohanes I Ketut Deddy Muliastra

Krystof Obidzinski

TECHNISCHE 



\title{
Large-scale plantations, bioenergy developments and land use change in Indonesia
}

\author{
Anne Casson \\ Center for International Forestry Research (CIFOR) \\ Yohanes I Ketut Deddy Muliastra \\ Center for International Forestry Research (CIFOR) \\ Krystof Obidzinski \\ Center for International Forestry Research (CIFOR)
}


Working Paper 170

๑ 2014 Center for International Forestry Research

(1) Content in this publication is licensed under a Creative Commons Attribution 4.0 International (CC BY 4.0), http://creativecommons.org/licenses/by/4.0/

ISBN 978-602-1504-66-6

Casson A, Muliastra YIKD and Obidzinski K. 2014. Large-scale plantations, bioenergy developments and land use change in Indonesia. Working Paper 170. Bogor, Indonesia: CIFOR.

Photo by Agus Andrianto/CIFOR

Oil palm plantation at forest edge in Papua, Indonesia.

CIFOR

Jl. CIFOR, Situ Gede

Bogor Barat 16115

Indonesia

$\mathrm{T}+62(251) 8622-622$

$\mathrm{F}+62(251) 8622-100$

E cifor@cgiar.org

\section{cifor.org}

We would like to thank all donors who supported this research through their contributions to the CGIAR Fund. For a list of Fund donors please see: https://www.cgiarfund.org/FundDonors

Any views expressed in this publication are those of the authors. They do not necessarily represent the views of CIFOR, the editors, the authors' institutions, the financial sponsors or the reviewers. 


\section{Table of contents}

Abbreviations vii

Conversion factors $\quad$ vii

Acknowledgments viii

Abstract

Introduction

1 Bioenergy plantations in Indonesia 4

Oil palm 4

Timber 9

Sugarcane 13

$\begin{array}{ll}\text { Cassava } & 17\end{array}$

Jatropha 20

Summary

2 Bioenergy developments in Indonesia 23

Biofuel 24

Biodiesel 26

Bioethanol 27

Biogas methane capture $\quad 29$

Wood pellet demand 30

Summary 32

3 Policies that have influenced bioenergy plantation development in Indonesia 34

Policies to initiate bioenergy development 34

Land use allocation policies 35

Incentives for investment in biofuels 36

Trade and commercial policies 37

Summary

4 Challenges affecting the growth of bioenergy crops 39

Price fluctuations and competition with fossil fuels 39

Competition with food crops 41

Negative press coverage and foreign policy restrictions 41

Complicated land application and permit processes 42

Land tenure issues and lack of clarity over land ownership 43

Poor infrastructure 44

Limited access to technology and capital 45

Weak law enforcement 45

Summary 46

5 Deforestation and the socioeconomic causes of land use change in Indonesia 47

Demographic drivers of deforestation $\quad 50$

Policy drivers of deforestation 53

Economic drivers of deforestation 56

Summary 
6 The impact of plantation expansion on land use change and greenhouse gas emissions $\quad 60$

Oil palm and land use change

Industrial timber plantations and land use change $\quad 62$

Deforestation and bioenergy feedstocks $\quad 63$

Land use change and above-ground greenhouse gas emissions 63

Land use change and below-ground greenhouse gas emissions 64

$\begin{array}{ll}\text { Summary } & 67\end{array}$

7 Measures being taken to reduce adverse impacts $\quad 70$

$\begin{array}{ll}\text { Land use permit review } & 70\end{array}$

Efforts to optimize degraded land $\quad 71$

Moratorium on clearing of forests and peatlands $\quad 73$

The One Map initiative $\quad 75$

REDD projects and policies $\quad 77$

$\begin{array}{ll}\text { National and regional mitigation action plans } & 79\end{array}$

$\begin{array}{ll}\text { Environmental impact assessments } & 81\end{array}$

Efforts to encourage sustainable biofuel production $\quad 81$

Sustainability criteria in other countries $\quad 84$

Summary $\quad 84$

8 Conclusion $\quad 86$

$\begin{array}{lr}\text { References } & 89\end{array}$

Appendices

$1 \quad$ Planned and existing oil palm plantations on mineral and peat soils 100

2 Planned and existing timber plantations on mineral and peat soils $\quad 102$

3 Location of estate crop plantation licenses in Kalimantan $\quad 104$

4 Location of estate crop plantation licenses in Sumatra 105

5 Location of estate crop plantation licenses in Papua 106

6 Location of timber plantation licenses in Kalimantan $\quad 107$

7 Location of timber plantation licenses in Sumatra 108

8 Location of timber plantation licenses in Papua 109

9 Estimates of $\mathrm{CO}_{2}$ emissions related to drainage depth for different land use types $\quad 110$

10 Companies certified by the Roundtable on Sustainable Palm Oil in Indonesia, 2012

11 Roundtable on Sustainable Palm Oil principles and criteria 118

12 Roundtable on Sustainable Biomaterials principles and criteria $\quad 120$ 


\section{List of boxes, figures and tables}

Box

1 Dominant sugar companies in Indonesia

\section{Figures}

1 Oil palm area increase by province in 2011.

2 Oil palm area increase by type of plantation, 1990-2011. 5

3 World producers of crude palm oil, 2011 (thousand metric tonnes). 6

4 Global consumption of crude palm oil in 2010 (thousand metric tonnes). 6

5 Value of Indonesia's crude palm oil exports, 2010 (USD thousand).

6 Existing and planned pulp and paper mills in Indonesia. 11

7 Area of sugarcane smallholdings and government and private plantations, 1990-2011. 13

8 Sugarcane plantation area change by province, 2011.

9 World producers of sugarcane, 2011 (thousand tonnes). 15

10 Global consumption of sugarcane, 2011/2012 (thousand tonnes). 16

11 Sources of Indonesia's sugarcane imports, 2011 (tonnes). 16

12 Indonesian exports of sugarcane, 2011 (tonnes). 17

13 Cassava plantation area, 1990-2011. 18

14 Cassava plantation area change by province, $2011 . \quad 19$

15 Global producers of cassava in 2011 (thousands of tonnes). 19

16 Global producers of biofuel, 2011 (millions of tonnes). 24

17 Global consumption of biofuel, 2011 (million of tonnes). 25

18 Global biodiesel production, 2011 (thousand barrels per day). 26

19 Global consumption of biodiesel, 2011 (million tonnes). 27

20 Global producers of bioethanol, 2011 (thousand barrels per day). 28

21 Indonesia's energy mix: 2005 and target for 2025.

22 Price of palm oil (USD per metric tonne) in northwest Europe, 1988-2013. 39

23 Price of sugar (US cents per pound) on the international market, 2003-2013. 40

24 Degraded land area by province (ha).

25 Differences between the 2009 Ministry of Forestry and Ministry of Environment land cover
maps of Papua.

26 Indonesia's nationwide emissions, 2004.

\section{Tables}

1 Forest cover in Indonesia according to the Ministry of Forestry, 2011.

2 Forest functions within the Indonesian state-owned forest, 2011.

3 Forest cover, 2010.

4 Comparative yields of vegetable oil plants. 6

5 Landholdings of the top 10 actors in Indonesia's oil palm sector. 8

6 Area planted with oil palm, current and projected. 8

7 Area (ha) planted with oil palm by region, 1991-2011. 9

8 Planted area and area allocated for industrial timber plantations, 1990-2011. 10

9 Jatropha cultivation area and production, 1990-2011. 21

10 Planted area, 1990-2011. 22

11 Energy consumption, 2000-2011 (thousand BOE, barrel of oil equivalent). 23

12 Supply of primary energy (\%) excluding biomass, 2000-2011. 24

13 Fuel consumption in the transportation sector (kiloliters). 25

14 Biodiesel production and capacity (million liters), 2006-2013. 26 
15 Yield and greenhouse gas savings of bioethanol feedstocks.

16 Fuel ethanol production and capacity growth (million liters), 2006-2013. 29

17 Forest cover loss according to MoF data in 1982 and 2009.

18 Deforestation estimates.

19 Population growth in Indonesia, 1971-2010. 51

20 Key actors in Indonesian forest policy.

21 Key economic drivers of deforestation. 56

22 Indonesia's five-year development plans, 1969-2004. 58

23 Forest area released for plantations from 2006 to 2011.

24 Land allocated to oil palm plantations in Indonesia on peat and forested land until 2011 (ha). $\quad 61$

25 Land allocated to timber plantations on peat and forested land to 2011 (ha). 62

26 Estimates of carbon stock by land use. 65

27 Peatland area by province. 66

28 Annual values for peat carbon losses from plantations over various time scales. 67

29 Annual net peat emissions from oil palm and acacia plantations $\left(\mathrm{Mg} \mathrm{CO}_{2}\right.$-equivalent/ha/year). $\quad 67$

30 Tier $1 \mathrm{CO}_{2}$ emission/removal factors for drained organic soils in selected land use categories. $\quad 67$

31 Land allocated for oil palm and industrial timber plantations (ha). 68

32 Moratorium map revisions. $\quad 74$

33 Government institutions generating land cover maps in Indonesia. 76

34 Differences between the 2009 Ministry of Forestry and Ministry of Environment
land cover maps. 


\section{Abbreviations}

$\begin{array}{ll}\mathrm{CO}_{2} & \text { carbon dioxide } \\ \text { CPO } & \text { crude palm oil } \\ \text { EIA } & \text { environmental impact assessment } \\ \text { EU } & \text { European Union } \\ \text { GDP } & \text { gross domestic product } \\ \text { GHG } & \text { greenhouse gas } \\ \text { ha } & \text { hectare } \\ \text { HGU } & \text { hak guna usaha, land use right } \\ \text { IDR } & \text { Indonesian rupiah } \\ \text { IPCC } & \text { Intergovernmental Panel on Climate Change } \\ \text { ISPO } & \text { Indonesian Sustainable Palm Oil } \\ \text { m } & \text { meter } \\ \text { mm } & \text { millimeter } \\ \text { POME } & \text { palm oil mill effluent } \\ \text { REDD } & \text { Reduced Emissions from Avoided Deforestation and Degradation } \\ \text { REDD+ } & \text { Reducing Emissions from Deforestation and Forest Degradation, and Enhancing Forest } \\ & \text { Carbon Stocks in Developing Countries } \\ \text { RSB } & \text { Roundtable on Sustainable Biomaterials } \\ \text { RSPO } & \text { Roundtable on Sustainable Palm Oil } \\ \text { UKP4 } & \text { Unit Kerja Presiden bidang Pengawasan dan Pengendalian Pembangunan, President's Delivery } \\ & \text { Unit for Development Monitoring and Oversight } \\ \text { UNFCCC } & \text { United Nations Framework Convention on Climate Change } \\ \text { US } & \text { United States } \\ \text { USD } & \text { United States dollar }\end{array}$

\section{Conversion factors}

$\begin{array}{ll}1 \text { tonne of palm oil } & =1100 \text { liters } \\ 1 \text { tonne of petrol } & =1362 \text { liters } \\ 1 \text { tonne of diesel } & =1195 \text { liters } \\ 1 \text { tonne of ethanol } & =1324 \text { liters } \\ 1 \text { tonne of biodiesel } & =1132 \text { liters } \\ 1 \text { barrel of biodiesel } & =170 \text { liters } \\ 1 \text { kiloliter } & =1000 \text { liters } \\ 1 \text { pound } & =0.45359 \text { kilograms }\end{array}$




\section{Acknowledgments}

The authors gratefully acknowledge the support received from the Federal Ministry of Food and Agriculture, Germany and the Technical University of Darmstadt. The authors would like to express appreciation to Prof. Uwe Lahl of the Technical University of Darmstadt; Pablo Pacheco, Andrew
Wardell, Agus Djoko Ismanto and Steven Lawry of the Center for International Forestry Research (CIFOR) for comments on earlier drafts of this paper. Special thanks also go to Heru Komarudin, Gideon Suharyanto and Vidya Fitrian of CIFOR for their contribution to the final version of this Working Paper. 


\section{Abstract}

Indonesia's forests make up one of the world's most biologically diverse ecosystems. They are rich in biodiversity and provide a range of valued products for local and global consumption. They store carbon and release large amounts of carbon dioxide into the atmosphere when they are destroyed, and consequently play a key role in climate change mitigation.

Indonesia's forests have long been harvested by local people to meet their daily needs. Large-scale extraction was initiated during the colonial era and accelerated in the 1970s, when Indonesia embarked upon a process of large-scale timber extraction from the outer islands (Kalimantan, Sumatra, Sulawesi and Papua). A complex range of demographic, economic and policy factors have driven forest extraction since the 1970s and resulted in widespread deforestation, particularly in Sumatra and Kalimantan.

Recent interest in developing energy from biofuels and other renewable energy sources (such as wood pellets) is potentially creating a new threat. Increasing oil prices, rising energy demands and concerns over global warming and nuclear power have encouraged many countries, including Indonesia, to develop energy from biomass that can be sourced from agricultural crops such as oil palm, sugar, cassava, jatropha and timber plantations. So far, significant area expansion in Indonesia has only occurred for oil palm and industrial timber plantations (butan tanaman industri).

Key factors behind deforestation and land use change in present-day Indonesia are thought to be the expansion of the oil palm, plywood and pulp and paper industries. All are promoted in economic development plans such as Masterplan Percepatan dan Perluasan Ekonomi Indonesia or master plan for acceleration and expansion of Indonesia's economic development (Coordinating Ministry for Economic Affairs 2011) (hereinafter "development master plan").

Oil palm has been one of the fastest-growing sectors of the Indonesian economy, increasing eightfold since 1991 to 8.9 million hectares (ha) in 2011. Most oil palm growth has occurred in the six provinces of
Riau, East Kalimantan, Central Kalimantan, West Kalimantan, North Sumatra and Jambi. Another 7 million ha of oil palm is expected to be planted by 2025. Carbon-rich forest and peatland are often cleared to make way for oil palm estate expansion, and the statistics at the Ministry of Forestry suggest that licenses have been issued to establish oil palm estates on another 891,902 ha of peatland and 3.9 million ha of forest in the near future.

The plywood, pulp and paper industries have also expanded significantly since log exports were banned in 1985. Industrial timber plantations have been established to supply the timber processing industry; however, supply has not kept up with demand. Natural timber has consequently been cleared via illegal logging and clearing of natural forests to make way for timber and oil palm plantations. Industrial timber plantations are also being established on carbon-rich peatland and have replaced natural forest. Available statistics indicate that more than 1 million ha of peatland and 2.8 million ha of forest land have been allocated for the establishment of industrial timber plantations.

Several measures are being undertaken to ensure that large-scale timber, oil palm and other crops do not cause further unnecessary deforestation or other adverse impacts in Indonesia. These measures have arisen because of growing global concern about the impact of deforestation on biodiversity and global warming and the Indonesian government's commitment to reduce greenhouse gas emissions from peat degradation, deforestation and land degradation. Some of these measures are being taken internally, while others are being implemented by consuming countries or by organizations established to promote sustainable production and reduce greenhouse gas emissions. This report explains and analyzes these measures. The outcome of current and planned government regulations and privatesector initiatives is difficult to predict with precision; it depends on the political orientation of the government in Indonesia and on market conditions affecting the private sector. 


\section{Introduction}

Indonesia's forests are among the most biologically diverse ecosystems on earth. With 15 natural forest types, Indonesia provides habitat for $17 \%$ of the world's bird species, $16 \%$ of reptiles and amphibians, $12 \%$ of mammals and $10 \%$ of flowering plants (MacKinnon et al. 1996). The natural forests of Kalimantan and Papua are rich in biodiversity, each containing over 900 plant species (MacKinnon et al. 1996; Marshall and Beehler 2007). Natural forest types with high biological diversity include coastal mangrove forests, lowland peat swamp and dipterocarp forests, and montane forests (MacKinnon et al. 1996). The forests have long been valued not just for timber but for many other products, such as rattan, bush meat, resins, rare woods such as gaharu and aloe wood, wild rubber, edible birds' nests and beeswax (Potter 1991). In recent years, they have also become valued because of their carbon stores, which can be released as carbon dioxide $\left(\mathrm{CO}_{2}\right)$ when they are destroyed.

Indonesia is bisected by Wallace's Line, an imaginary line that runs between Sulawesi and Kalimantan and divides Indonesia into two distinct floral and faunal provinces. The western islands, especially Sumatra and Kalimantan, are dominated by species of the tall, canopy-dominant family Dipterocarpacae. Further east, forests have a mixture of hardwood species that includes some dipterocarps. The tropical moist forest of the higher-rainfall outer islands - notably Sumatra, Kalimantan, Sulawesi, Maluku and Papua - are the most extensive and valuable in ecological, hydrological and economic terms (Potter 1991).

Forests are vital for the livelihoods of the people who live in and around them, many of whom still rely on natural forests to supply a significant portion of their food, fuel, medicine and other subsistence needs (Sunderlin et al. 2005). Large numbers of people in forested regions also obtain cash incomes from informal timber harvesting and from employment with logging, plantation and wood processing companies (World Bank 2006).

Ministry of Forestry statistics indicate that there were 99.5 million ha of forest remaining in Indonesia in 2011 (MoF 2012; Table 1).
Table 1. Forest cover in Indonesia according to the Ministry of Forestry, 2011.

\begin{tabular}{lcc}
\hline Forest type & Hectares & $\begin{array}{c}\text { Percentage of } \\
\text { total forest area }\end{array}$ \\
\hline Primary & 46.6 million & $46 \%$ \\
Secondary & 48.7 million & $49 \%$ \\
Plantation & 4.4 million & $5 \%$ \\
\hline
\end{tabular}

Source: MOF 2012.

The majority (91\%) of these forests lay within Indonesia's state-owned forest (kawasan hutan) (MoF 2012). The state-owned forest was originally determined in 1983 when the Ministry of Forestry classified forests into four classes: protection forest, conservation forest, limited-production forest (where logging was to be accompanied by measures to reduce soil erosion) and production forest for commercial logging and conversion forest, which is allocated for uses other than forestry. This classification dates back to the early 1980s and is based on what is called the Forest Land Uses by Consensus. This process produced a very rough estimate of the size of state-owned forest at about 144 million ha (Brockhaus et al. 2012). Despite data and technological limitations, the Forest Land Uses by Consensus has provided the country with the basis for sustainable forests management.

That is one of the reasons why since then, forest cover in Indonesia has decreased considerably; however, there has been little corresponding decrease in the extent of land within the stateowned forest. In 2012, the size of the state-owned forest is about 133.5 million ha (MoF 2012). The Ministry of Forestry operates under the premise that the boundaries of the state-owned forest should remain more or less the same and that deforested and degraded areas should be rehabilitated using reforestation programs. Consequently, the Ministry of Forestry maintains some of the territory under its jurisdiction as forest land without forests (Brockhaus et al. 2012); 42.5 million ha of the land within the state-owned forest is not forested (MoF 2012). 
Indonesia's total land area is estimated at 190,359,560 ha. Ministry of Forestry statistics indicate that the state-owned forest covered around $70 \%$ of Indonesias total land area in 2011. Around $38 \%$ of this forest area was designated for conservation and protection; the remaining $62 \%$ was allocated for economic development (Table 2).

Indonesia's forests have long been harvested by local people to meet their daily needs. Large-scale forest extraction began after the Dutch colonized the Indonesian archipelago (Peluso 1992). Natural forests were cleared to make way for teak and tea plantations on Java, and oil palm, rubber, tobacco and tea estates were established on Sumatra in an area known as the plantation belt (cultuurgebied) - an area between Medan and Lake Toba on Sumatra's east coast (Stoler 1985).

Despite this activity, plantations only covered a relatively small area in 1950 . The forest cover at that time is estimated to have been 145 million ha of primary forest and another 14 million ha of secondary and tidal forest, which is composed of trees and vegetation tolerant of salty water (Barber et al. 2002). Extensive forest loss had only occurred in a few regions by 1950 , primarily on the islands of Java and Bali. Some forest was also lost within Sumatra's plantation belt. This is primarily attributed to colonial timber extraction, population growth and agricultural expansion (Peluso 1992).

In the early 1970 s, Indonesia embarked upon a process of large-scale forest extraction from the outer islands (primarily Sumatra and Kalimantan) for economic benefit and development. Timber extraction began with large-scale logging to generate export revenue and later fed Indonesias growing timber processing industry. From the early 1990s to 2000, production capacity increased nearly $700 \%$ in the pulp and paper industries, making Indonesia the world's 9th largest pulp producer and 11th largest paper producer. The expansion of these industries since then has created a level of demand that could not be met by any sustainable forest management system and resulted in forest loss (ABC 2002). Natural forest has been lost due to extraction of raw materials through logging and clear felling. Clear felling is often followed by the establishment of oil palm and industrial timber plantations, which have been promoted to meet the demand of Indonesias timber processing industry, reduce demand for fossil fuels and stimulate investment in bioenergy. Forest extraction has been dominant in Sumatra and Kalimantan and is now moving to the island of Papua.
Table 2. Forest functions within the Indonesian stateowned forest, 2011.

\begin{tabular}{lc}
\hline Category & Million ha \\
\hline Conservation forest (hutan konservasi) & 20.09 \\
Protected forest (hutan lindung) & 31.59 \\
Production forest (hutan produksi) & 36.74 \\
Limited production forest (hutan & 22.34 \\
produksi terbatas) & \\
Conversion forest (hutan produksi yang & 22.74 \\
dapat dikonversi) & \\
\hline Total & 133.50 \\
\hline
\end{tabular}

Source: MoF 2012.

Parts of Java and Bali and the Sumatra plantation belt were deforested over 100 years ago. Forest cover in these areas is now stabilizing and is being replaced by plantations. Sumatra, Kalimantan and Sulawesi have undergone significant deforestation over the last 40 years. Papua's forests remain relatively intact but are expected to be the new frontier of deforestation over the next few decades. The majority of Indonesia's primary forests in 2010 lay in Papua, followed by Kalimantan and Sumatra (Table 3). ${ }^{1}$

This paper explores the development of plantation crops that have recently been promoted for bioenergy production and its implications for land use change in Indonesia. It also reviews the current status and likely future trajectories of investment and land acquisition in bioenergy plantations in Indonesia and assesses their implications for indirect and direct land use change. The final section reviews a number of governance measures being taken to promote more sustainable agriculture and bioenergy production. Some of these measures also seek to reduce deforestation and greenhouse gas (GHG) emissions in Indonesia.

1 The process of deforestation and plantation establishment in Indonesia is in line with the forest transition curve put forward by Mather (1992), who suggested that in a country with a high and relatively stable portion of land under forest cover, deforestation begins, then accelerates, and forest cover diminishes, until at some point deforestation slows and forest cover stabilizes and begins to recover. This theory can be applied both to countries and regions within countries (Angelsen 2009). 
Table 3. Forest cover, 2010.

\begin{tabular}{lrrrr}
\hline Province & Primary forest & Secondary forest & Plantation forest & \multicolumn{1}{c}{ Total forest } \\
\hline Sumatra & $4,756,700$ & $9,102,800$ & 983,900 & $14,843,400$ \\
Java & 306,700 & $1,116,700$ & $2,595,000$ & $4,018,500$ \\
Bali & 44,200 & 57,400 & 1,800 & 103,400 \\
Nusa Tenggara & 666,200 & $1,922,000$ & 3,100 & $2,591,300$ \\
Kalimantan & $9,894,500$ & $18,445,500$ & 818,200 & $29,158,200$ \\
Sulawesi & $3,915,100$ & $6,185,400$ & 16,700 & $10,117,200$ \\
Maluku & $1,059,200$ & $4,227,000$ & 32,000 & $5,318,200$ \\
Papua & $25,801,700$ & $7,633,600$ & 1,800 & $33,437,100$ \\
Total for Indonesia & $46,444,400$ & $48,690,300$ & $4,452,600$ & $99,587,300$ \\
\hline
\end{tabular}

Source: MoF 2012. 


\section{Bioenergy plantations in Indonesia}

Four main feedstocks have been targeted for biofuel development in Indonesia - cassava (mostly in Java), jatropha (mostly in eastern Indonesia), oil palm (in Sumatra, Kalimantan and Papua) and sugarcane (in Sumatra and Sulawesi). This section examines the expansion rates of these crops and their contribution to Indonesia's emerging biofuel sector. The development of industrial timber plantations is also examined, as these plantations are beginning to produce a new form of biomass - wood pellets.

\section{Oil palm}

The oil palm tree (Elaeis guineensis Jacq.) is native to West Africa, where it was traditionally used to make food, medicine, textiles and wine. It is now planted in large-scale plantations throughout the tropics, because palm oil is used in a number of commercial products including cooking oil, soap, cosmetics and margarine. Palm oil is also used as a lubricant in industrial processes and to produce plastics, textiles, emulsifiers, esters, explosives and pharmaceutical products (FFP and SawitWatch 2006). Crude palm oil (CPO) is the primary product derived from the red fruit of the oil palm, while palm kernel oil, derived from the fruit's nut, is considered a secondary product. Palm kernel meal is primarily used for animal feed (Cheng Hai 2002).

Rising mineral oil prices and challenges arising from climate change have motivated interest in palm oil as a renewable energy source. Like other vegetable oils, palm oil can be used to fuel internal combustion engines in vehicles and in stationary plants - power stations, district heating stations and (block-type) cogeneration plants, which simultaneously generate electricity and heat (WWF 2007). It can also be used as a biofuel, but either it has to be processed to make it similar to mineral diesel fuel, or vehicles and machines have to be modified to accept pure vegetable oil.

\section{Area expansion}

Palm oil plantations have expanded significantly over the last 20 years. Dutch traders established the first large-scale Indonesian oil palm plantations in 1911, primarily in Sumatra and Java (Stoler 1985). These plantations were nationalized in 1957 and were neglected until President Suharto began to create conditions for renewed investment in the forestry and plantation sector in 1968. Between 1986 and 1996, private oil palm estate growth was stimulated by government schemes that encouraged greater private-sector investment by granting access to credit at concessionary rates for estate development, new crop planting and crushing facilities (Larson 1996). Smallholder growth was also stimulated by government schemes that aimed to encourage private estate sector involvement in smallholder development: the PIR-Trans program (Perkebunan Inti Rakyat Transmigrasi or Nucleus Estate and Smallholder Scheme for Transmigrants, 1985-1994) and the Prime Cooperative Credit for Members Scheme (1995-1998). In both of these schemes, smallholders were given 5-7.5 ha of land and were then reallocated $2-3$ ha to plant oil palm, along with an additional $0.5-1$ ha for housing and subsistence agriculture (FPP and Sawit Watch 2006).

Since the 1997 economic crisis, the Indonesian government has encouraged the expansion of private and smallholder oil palm plantations by endeavoring to keep the export tax on CPO below $5 \%,{ }^{2}$ increasing the maximum size allowed for oil palm plantation developments from 25,000 ha to 100,000 ha per company (Menteri Pertanian PP 26/2007 tentang Pedoman Perizinan Usaha Perkebunan), ${ }^{3}$ and extending the license to use and exploit land for plantation development from 25 to 35 years. It has also offered subsidized loans with interest rates of $10 \%$ to smallholders developing, replanting or rehabilitating oil palm plantations on 4 ha of land over a five-year period (Menteri Pertanian PP 33/2006 tentang Pengembangan Perkebunan Melalui Revitalisasi Perkebunan).

Since 1991, oil palm has been one of the fastestgrowing sectors of the Indonesian economy, increasing eightfold and totaling 8.9 million ha in 2011

\footnotetext{
2 Despite this policy, the tax on CPO exports has fluctuated between 60\% (in 1999) and 2.5\%. A ban on CPO exports was also put in place between January and April 1998 to ensure a constant supply of cooking oil to the domestic market when CPO prices rose.

3 This regulation also states that there is no plantation limit for cooperatives, state-owned companies and publicly listed companies, the majority share of those is owned by public.
} 
(Bisinfocus 2012). Most oil palm growth between 1991 and 2011 occurred in the six provinces of Riau (by 1.9 million ha), Central Kalimantan (by 973,650 ha), West Kalimantan (by 715,503 ha), North Sumatra (by 565,662 ha), Jambi (by 449,995) and East Kalimantan (by 447,172) (Figure 1).

Private and smallholder oil palm estates have been responsible for the majority of this growth. By 2011, privately owned oil palm estates had planted oil palm on approximately 4.6 million ha, while smallholders and government estates had planted oil palm on 3.6 million ha and 0.64 million ha, respectively. Between 1990 and 2001, private estate area planted to oil palm increased from 403,093 ha to 4.6 million ha, while smallholder plantations increased from 291,328 ha to 3.62 million ha. Government estates showed less of an increase: from 372,246 ha in 1991 to a peak of 687,428 ha in 2006; their area declined to 640,000 ha in 2011 (Figure 2). Private and smallholder oil palm estates are expected to continue to expand over the next decade.

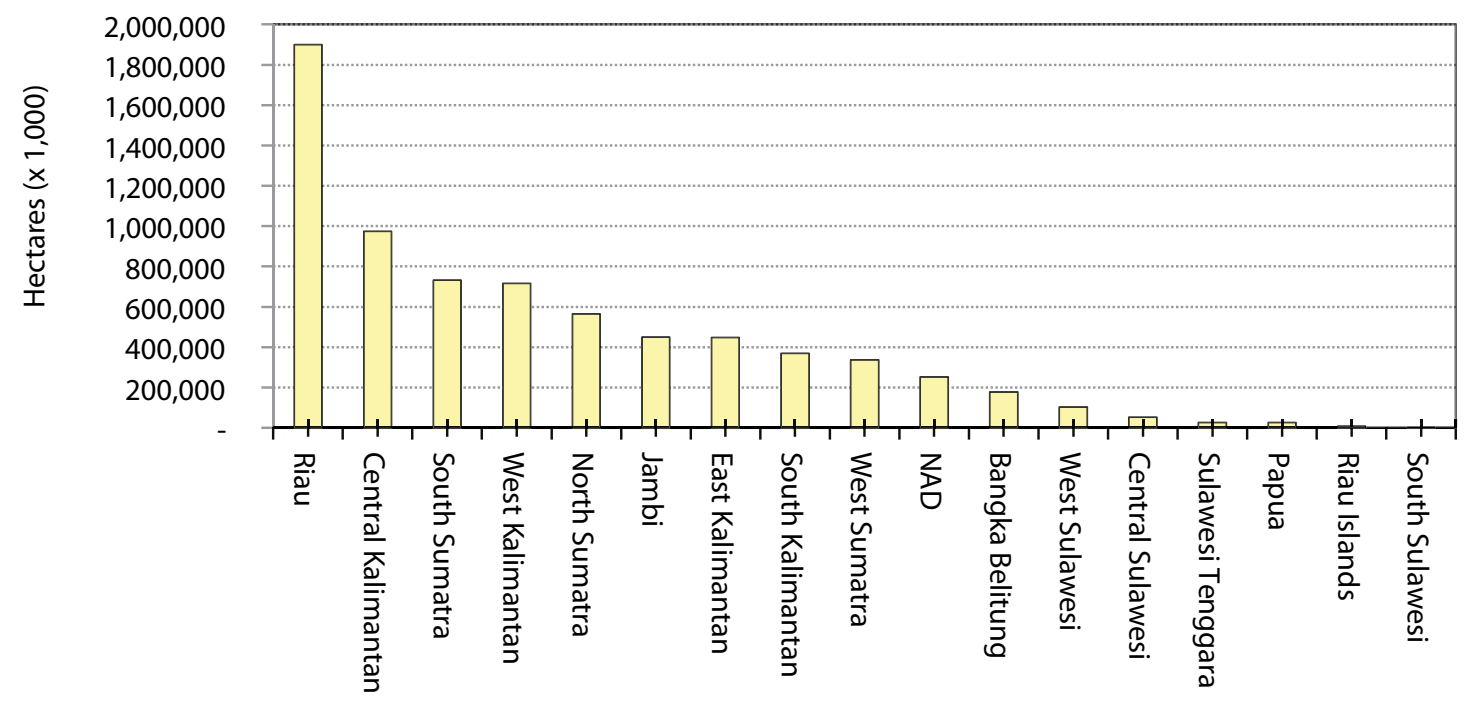

Figure 1. Oil palm area increase by province in 2011.

Sources: Bisinfocus $(2006,2012)$.

Smallholders

Government Plantations

Private Plantations

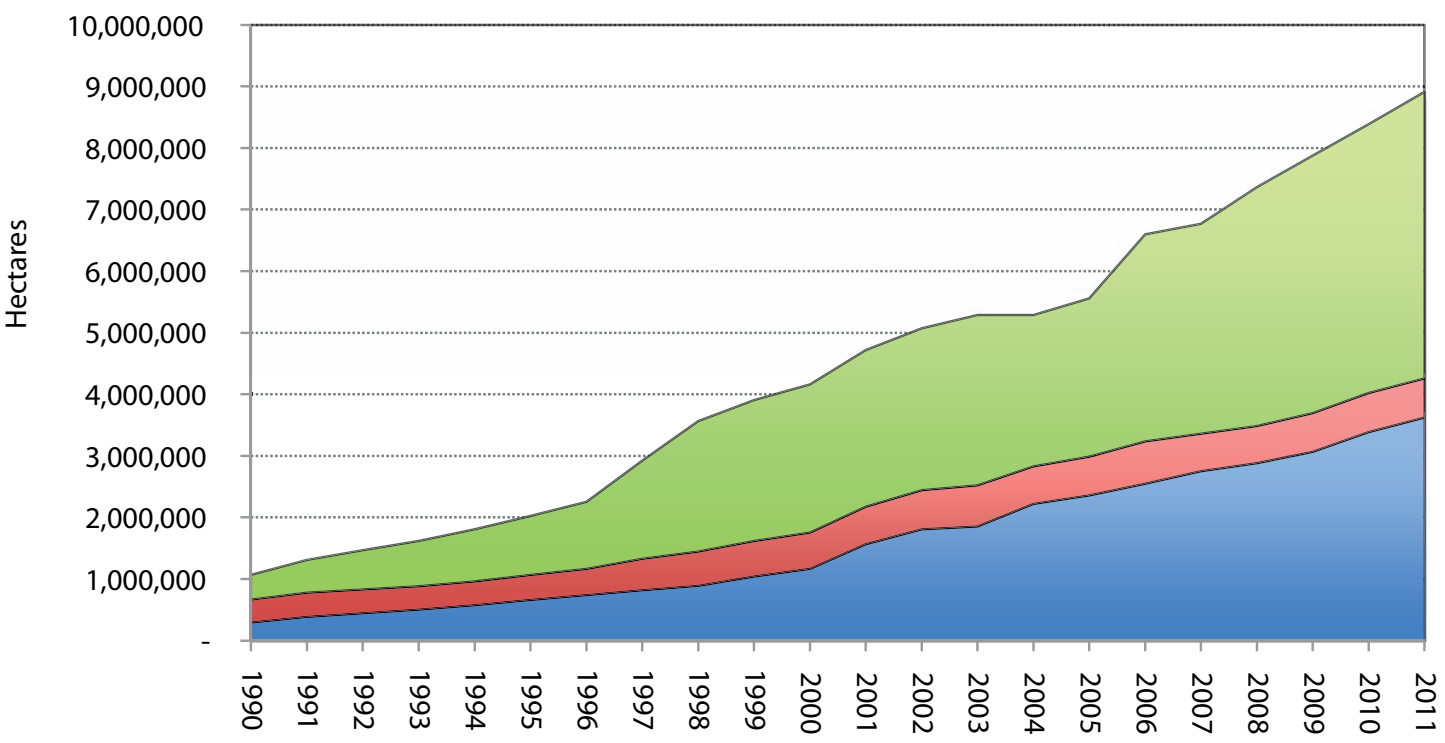

Figure 2. Oil palm area increase by type of plantation, 1990-2011.

Sources: Bisinfocus $(2006,2012)$. 


\section{Production}

Palm oil currently dominates the world vegetable oil market. In 2012, 52.27 million metric tonnes of palm oil was produced globally. The next largest global vegetable oil sources were soybean at 43.33 million metric tonnes and rapeseed at 23.89 million metric tonnes (Bisinfocus 2012). Minor feedstocks for the global vegetable oil market include coconut, cottonseed, olive, peanut, palm kernel and sunflower seed.

Oil palm is one of the highest-yielding oil plants in the world (Table 4), which effectively means that it uses land more efficiently than other vegetable-oil crops (Härdter and Fairhurst 2003).

Indonesia overtook Malaysia in 2006 to become the number one producer of CPO in the world (Bisinfocus 2012). In 2011, Indonesia produced 23.9 million tonnes of CPO to Malaysia's 18.8 million tonnes. Together, Malaysia and Indonesia produced around $84 \%$ of the world's palm oil. Minor producers of CPO include Columbia, Nigeria, Thailand and Ecuador (Figure 3).

\section{Consumption}

Global demand for palm oil has increased exponentially, making it the most consumed edible oil in the world (Bisinfocus 2012). Most of the world's palm oil is consumed in the European Union and in Asia, primarily in India, China, Indonesia, Malaysia and Pakistan, where it is used as cooking oil; it is a staple food for the inhabitants of most of these countries (Figure 4). Indonesia is the main consumer of its own CPO; it consumed $24 \%$ of its total production for 2011 (Bisinfocus

Table 4. Comparative yields of vegetable oil plants.

\begin{tabular}{lcc}
\hline \multirow{2}{*}{ Plant } & \multicolumn{2}{c}{ Oil per hectare } \\
\cline { 2 - 3 } & Kilograms & Liters \\
\hline Oil palm & 5000 & 5950 \\
Coconut & 2260 & 2689 \\
Jatropha & 1590 & 1892 \\
Rapeseed & 1000 & 1190 \\
Peanut & 890 & 1059 \\
Sunflower & 800 & 952 \\
Soybean & 375 & 446 \\
Corn (maize) & 145 & 172 \\
\hline
\end{tabular}

Sources: Bromokusumo (2007) and Atabani et al. (2012).

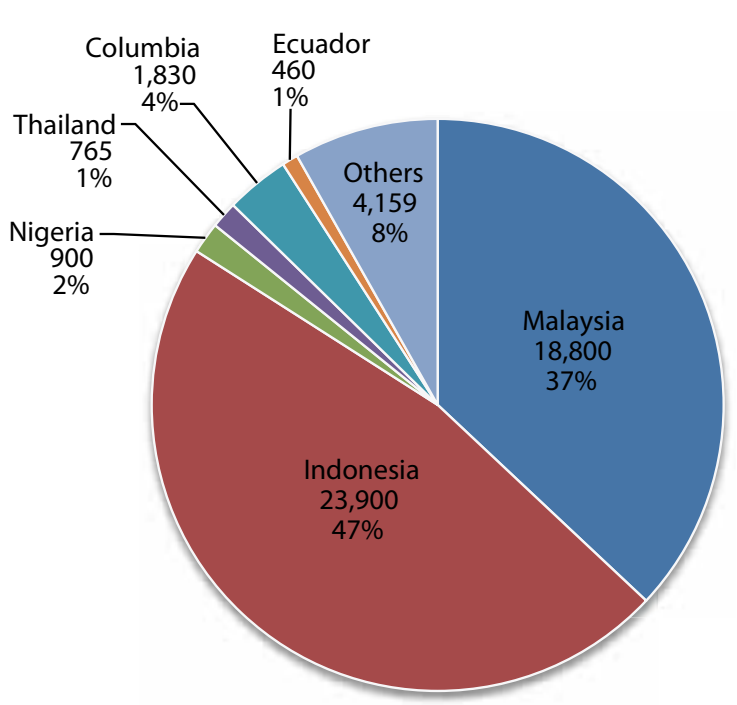

Figure 3. World producers of crude palm oil, 2011 (thousand metric tonnes).

Source: Bisinfocus (2012).

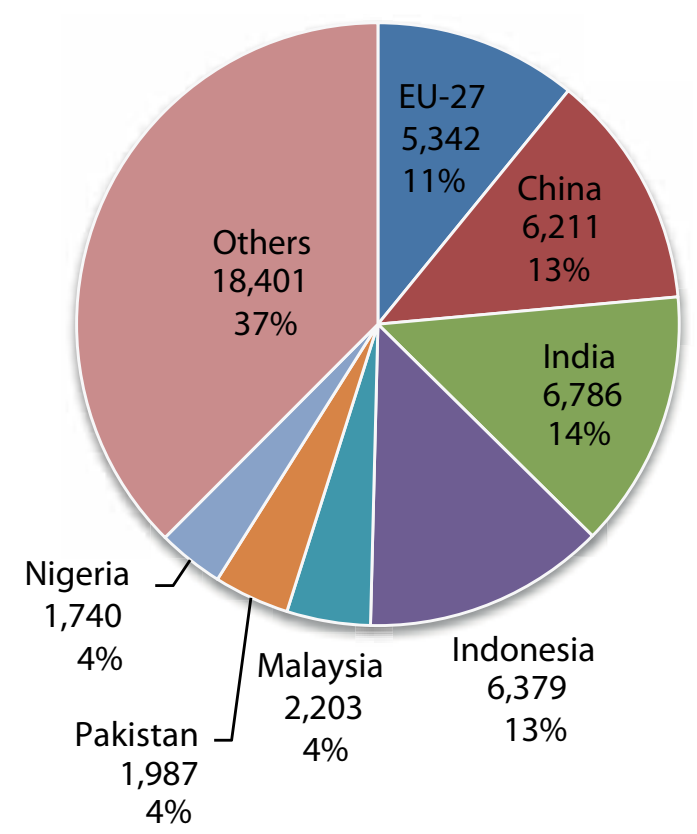

Figure 4. Global consumption of crude palm oil in 2010 (thousand metric tonnes).

Source: Bisinfocus (2012).

2012). Since 1996, consumption of CPO-based biodiesel has also increased, from 5 million liters (4,545 tonnes) in 2006 to 500 million liters (454,545 tonnes) in 2012 (Slette and Wiyono 2012).

\section{Economic significance}

The prolific growth of the oil palm sector has conferred important economic benefits on Indonesia: 
palm oil has become a valuable source of foreign exchange and employment and has resulted in attractive returns for investors.

In 2010, 16.2 million tonnes of palm oil (73\% of that year's total production) were exported, bringing in about 13.46 billion US dollars (USD). This contributed around $2.5 \%$ of Indonesia's total GDP gross domestic product (GDP) of USD 539.352 billion. The majority $(71 \%)$ of Indonesia's export earnings in 2010 were generated from exporting $\mathrm{CPO}$ to India, the European Union (EU), China and Malaysia (Figure 5).

The oil palm sector has also generated considerable employment for the rural poor. Workers are primarily employed to maintain nurseries, plant and maintain seedlings, apply fertilizer and harvest the fruit. An average Indonesian oil palm plantation employs one person for about every 3 ha of oil palm (Barlow et al. 2003). ${ }^{4}$ This means that a 20,000 ha plantation employs around 6000 people, with many times that number supported directly or indirectly by the plantation. Indonesia's oil palm plantations employed an estimated 2.9 million people in 2011. In comparison, soybean plantations employ one person for about every $160-200$ ha, so a 20,000 ha soybean plantation would only directly employ around 100 125 people (Proforest 2003).

Many of Indonesia's large conglomerates are heavily engaged in the oil palm sector because it has proven to be profitable. Sinar Mas, Wilmar and the Salim group each has oil palm landholdings of over 450,000 ha, and other prominent Indonesian conglomerates, such as Astra Agro and Asian Agro, have landholdings of over 250,000 ha each (Table 5).

Smallholders also often opt to plant oil palm rather than other crops, such as rubber or rice, for the same reason: oil palm is more profitable. Analysis carried out by the World Agroforestry Center indicates that independent smallholdings can yield large returns on land and labor because they do not have the high infrastructure and management costs of large-scale plantations (Papenfus 2001). Smallholders do need clear tenure security in order to maximize yields and profits. They are also constrained by high capital costs for land-

4 Large-scale oil palm plantations have very high labor requirements during the establishment phase and the operational phase for tree-crop maintenance and harvesting (Budidarsono et al. 2012).

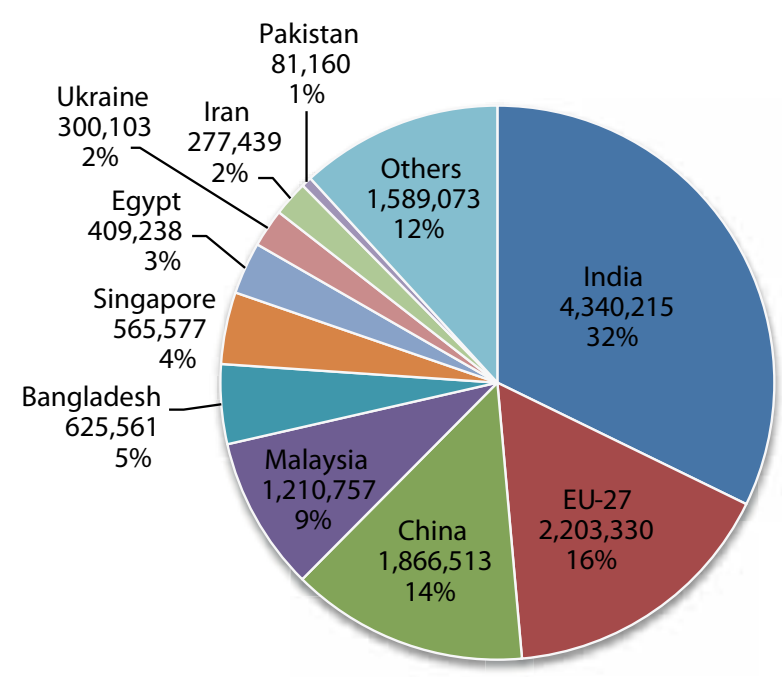

Figure 5. Value of Indonesia's crude palm oil exports, 2010 (USD thousand).

Source: Bisinfocus $(2012,102)$.

clearing machinery and fertilizer. ${ }^{5}$ In some cases, smallholders do not wish to cultivate a single crop. Research carried out in Kalimantan (Potter and Badcock 2007) found that Dayak communities want to plant oil palm, rubber and rice to meet their daily needs.

\section{Expected growth rates}

Indonesia’s oil palm sector is poised for further growth. Bisinfocus (2012) predicted that oil palm area will increase from 8.2 million ha in 2011 to 15.2 million ha in 2025 - an increase of 7 million ha (Table 6). The government's development master plan places a strong emphasis on increasing oil palm yields in Sumatra and Kalimantan. Investors are likely to be drawn to Indonesia's palm oil sector because Indonesia is perceived to have an abundant supply of suitable land, a favorable climate, low land rents and relatively cheap labor (Casson 1999).

Most of the new oil palm is likely to be planted in Sumatra and Kalimantan, although investors are increasingly looking at Papua and South Sulawesi as well. Oil palm grows best at a mean annual temperature of $24^{\circ} \mathrm{C}-28^{\circ} \mathrm{C}$, a mean annual rainfall of 1500-3000 millimeters ( $\mathrm{mm}$ ) and a mean relative humidity of $50 \%-70 \%$. It is therefore restricted to the zone of evergreen tropical rainforest on either side of the equator $\left(10^{\circ} \mathrm{S}-10^{\circ} \mathrm{N}\right)$ and to altitudes of

5 Fertilizer accounts for around $15 \%$ of production costs once a plantation has been established (Bahana 2007). 
Table 5. Landholdings of the top 10 actors in Indonesia's oil palm sector.

\begin{tabular}{|c|c|c|c|c|}
\hline Group or company & $\begin{array}{l}\text { Country of } \\
\text { ownership }\end{array}$ & $\begin{array}{l}\text { Concession } \\
\text { area (ha) }\end{array}$ & $\begin{array}{l}\text { Planted } \\
\text { area (ha) }\end{array}$ & $\begin{array}{l}\text { Annual CPO } \\
\text { production } \\
\text { (tonnes) }\end{array}$ \\
\hline Perkebunan Nusantara & Indonesia & 850,000 & 791,021 & $2,856,510$ \\
\hline Sinar Mas & Indonesia & 657,273 & 361,060 & $2,152,809$ \\
\hline Wilmar & Singapore & 599,055 & 183,469 & $1,778,882$ \\
\hline Indoagri/Salim & Indonesia & 492,370 & 254,989 & 836,000 \\
\hline Makin & Indonesia & 310,000 & 129,300 & 168,000 \\
\hline Triputra Agro & Indonesia & 309,000 & 109,796 & 204,044 \\
\hline $\begin{array}{l}\text { Asian Agri/Raja Garuda } \\
\text { Mas }\end{array}$ & Indonesia & 303,255 & 160,000 & 900,000 \\
\hline Astra Agro & Indonesia & 295,363 & 266,706 & $1,268,196$ \\
\hline $\begin{array}{l}\text { Bumitama/Bumitama } \\
\text { Gunajaya Agro Group }\end{array}$ & Indonesia & 191,561 & 87,581 & 345,111 \\
\hline Sampoerna Agro & Indonesia & 178,770 & 65,034 & 334,675 \\
\hline Total & & $4,186,647$ & $2,408,956$ & $10,844,227$ \\
\hline
\end{tabular}

a This is a state-owned company.

Source: Bisinfocus (2012).

Table 6. Area planted with oil palm, current and projected.

\begin{tabular}{lcc}
\hline Year & Planted area (ha) & Growth \\
\hline 2000 & $4,158,000$ & na \\
2005 & $5,553,000$ & $35 \%$ \\
2010 & $7,824,000$ & $41 \%$ \\
2011 & $8,200,000$ & $5 \%$ \\
\hline Projection & & \\
\hline 2015 & $10,199,000$ & $30 \%$ \\
2020 & $12,824,000$ & $26 \%$ \\
2025 & $15,249,000$ & $19 \%$ \\
\hline
\end{tabular}

na $=$ not applicable

Source: Bisinfocus (2012).

up to 500 meters (m) above sea level. In Indonesia these conditions can be found in western Sumatra, southern and northern Sulawesi, central and eastern Kalimantan, Java, Bali and the southern and northern parts of Papua.

Oil palm companies used to prefer Sumatra because it has the best climate and soil conditions in the country for cultivating oil palm. It also has the necessary infrastructure for palm oil processing, which needs to occur within 48 hours of harvesting (Casson 1999). In Riau, for instance, oil palm area growth increased by 1.89 million ha between 1991 and 2011. Significant expansion also occurred in South Sumatra, North Sumatra, Jambi, West Sumatra and Aceh during the same time period. Oil palm cultivation has increased dramatically in Kalimantan since 2003. Between 2003 and 2011, for instance, oil palm area increased by 733,198 ha in Central Kalimantan and by 366,925 ha in West Kalimantan (Table 7). These trends indicate that oil palm companies are likely to prefer to establish plantations in Sumatra and Kalimantan as long as there is available land. However, as land becomes scarce on these islands they are likely to expand into Papua. 
Table 7. Area (ha) planted with oil palm by region, 1991-2011.

\begin{tabular}{lrrrr}
\hline Province & \multicolumn{1}{c}{1991} & \multicolumn{1}{c}{$\mathbf{2 0 0 3}$} & \multicolumn{1}{c}{$\mathbf{2 0 1 1}$} & Growth, 1991-2011 \\
\hline Riau & 277,271 & $1,319,659$ & $2,176,864$ & $1,899,593$ \\
Central Kalimantan & 1,163 & 241,615 & 974,813 & 973,650 \\
South Sumatra & 94,166 & 502,481 & 826,743 & 732,577 \\
West Kalimantan & 68,229 & 416,807 & 783,732 & 715,503 \\
North Sumatra & 535,158 & 919,680 & $1,100,820$ & 565,662 \\
Jambi & 71,764 & 456,327 & 521,759 & 449,995 \\
East Kalimantan & 24,798 & 201,871 & 471,970 & 447,172 \\
South Kalimantan & 7,140 & 141,638 & 375,860 & 368,720 \\
West Sumatra & 42,709 & 306,496 & 379,185 & 336,476 \\
Nanggroe Aceh & 96,771 & 262,151 & 348,438 & 251,667 \\
Darussalam & & & & \\
Bangka Belitung & - & 94,886 & 177,683 & 177,683 \\
West Sulawesi & - & - & 103,182 & 103,182 \\
Central Sulawesi & 5,981 & 43,743 & 58,830 & 52,849 \\
Sulawesi Tenggara & - & 4,078 & 27,340 & 27,340 \\
Papua & 11,367 & 49,812 & 37,318 & 25,951 \\
Riau Islands & - & - & 9,170 & 9,170 \\
South Sulawesi & 19,569 & 78,932 & 20,667 & 1,098 \\
\hline Total & $1,294,633$ & $5,277,315$ & $8,895,786$ & $7,601,153$ \\
\hline
\end{tabular}

Sources: Bisinfocus (2006, 79; 2012, 70).

\section{Timber}

Teak plantations were first developed in Java during the Dutch colonial period. The plantation forests were eventually taken over by state-owned enterprises and continue to produce teak for the furniture and housing industries. Timber plantations began to expand into the outer islands in the 1990s, when Indonesia began to build up its pulp and paper and plywood industries. These plantations are dominated by acacia and eucalyptus, which grow quickly in Indonesia's tropical climate and can grow on marginal soils (Barr et al. 2010; Obidzinski and Dermawan 2012).

Investors were drawn to Indonesia's timber industry because soil and climatic conditions have resulted in plantation growth rates higher than those in most other parts of the world. Access to financing, human resources and indirect subsidies in the form of cheap timber from land clearing have also given the Indonesian pulp and paper industry an enviable advantage (Barr 2000, 2010; ITS 2011).

Industrial timber plantations primarily produce raw material for pulp and paper, plywood and sawn timber. Some plantations have also started to produce wood pellets - compressed biomass manufactured from wood waste including sawdust, shavings and wood chips.

Capacity growth has been led by the construction of a few large pulp mills that dominate the sector. The two largest mills, Indah Kiat and Riau Andalan Pulp and Paper, each have a capacity of 2 million tonnes per year and together account for around $62 \%$ of the total national capacity. The other large mills are Lontar Papyrus, Kiani Nusantara (previously known as Kiani Kertas), PT (limited company) Tanjung Enim Lestari and PT Toba Pulp Lestari (previously named PT Indorayon) (Jurgens 2007). Another large mill, PT Kertas Kraft Aceh, ceased production in 2007.

\section{Area expansion}

Ministry of Forestry statistics are inconsistent but indicate that 5.1 million ha of industrial timber plantations had been planted in Indonesia by 2011 and that over 10 million ha of land has been allocated for industrial timber plantations (Table 8). Industrial timber plantations have expanded on average by around 250,000 ha per year (MoF 2012). 
Table 8. Planted area and area allocated for industrial timber plantations, 1990-2011.

\begin{tabular}{|c|c|c|}
\hline Year & Planted area & $\begin{array}{l}\text { Area allocated for industrial } \\
\text { timber plantations }\end{array}$ \\
\hline 1990 & 131,655 & 30,000 \\
\hline 1991 & 301,529 & 30,000 \\
\hline 1992 & 515,520 & 83,083 \\
\hline 1993 & 750,373 & 83,083 \\
\hline 1994 & $1,123,980$ & 83,083 \\
\hline 1995 & $1,420,766$ & 114,013 \\
\hline 1996 & $1,747,214$ & $2,010,268$ \\
\hline 1997 & $2,137,755$ & $3,035,809$ \\
\hline 1998 & $2,453,589$ & $4,245,881$ \\
\hline 1999 & $2,636,624$ & $4,396,741$ \\
\hline 2000 & $2,755,286$ & $4,501,375$ \\
\hline 2001 & $2,857,603$ & $4,578,697$ \\
\hline 2002 & $2,925,075$ & $3,523,256$ \\
\hline 2003 & $3,043,583$ & $3,804,912$ \\
\hline 2004 & $3,168,274$ & $5,910,295$ \\
\hline 2005 & $3,300,188$ & $5,967,410$ \\
\hline 2006 & $3,463,313$ & $6,467,515$ \\
\hline 2007 & $3,695,267$ & $7,087,812$ \\
\hline 2008 & $4,108,158$ & $7,154,832$ \\
\hline 2009 & $4,413,623$ & $8,673,016$ \\
\hline 2010 & $4,693,582$ & $8,975,375$ \\
\hline 2011 & $5,150,821$ & $10,046,839$ \\
\hline
\end{tabular}

Sources: ITS (2011), MoF (2012).

Ministry of Forestry statistics do not specify where these plantations are, but it can be assumed that large areas have been allocated near pulp and paper mills in Riau, Jambi, East Kalimantan and North Sumatra. Spatial data indicate that 8.9 million ha (instead of the 10 million ha documented in statistical data) has been allocated for industrial timber plantations, and reveal that most of the land allocated to industrial timber plantations is in the provinces of Riau (1.59 million ha), South Sumatra (1.52 million ha), Central Kalimantan 1.4 million ha), West Kalimantan (1.2 million ha) and East Kalimantan (1 million ha) (Appendix 2).

The mills of Indah Kiat and Riau Andalan Pulp and Paper are both located in Riau, Sumatra, less than $60 \mathrm{~km}$ apart (Figure 6). Lontar Papyrus is located in Jambi province, PT Tanjung Enim Lestari in South Sumatra Province and PT Toba Pulp Lestari in North Sumatra Province. The newest pulp mill investment in Indonesia - the PT OKI Pulp and Paper Mill in South Sumatra near Palembang — is set to start production in 2016 and is expected to produce 2 million tonnes of pulp per year. Like Riau Andalan Pulp and Paper, it belongs to the Asia Pulp and Paper group (Antara News 2013). The Kiani Nusantara mill, the only large mill not in Sumatra, is located in East Kalimantan (Barr et al. 2010).

Industrial tree plantation development is supported through the Ministry of Forestry's Hutan Tanaman Industri program, which was initiated in the late 1980s, largely to provide a secure supply of raw materials to the pulp and paper industry (Barr 2000). This program has been subsidized by the government's reforestation fund, which provided $14 \%$ of projects' total cost in the form of equity capital and $32.5 \%$ in the form of a no-interest loan with a repayment period of 10 years. It also allowed companies to draw loans from the reforestation fund at commercial rates to finance $32.5 \%$ of a project's expenses, effectively allowing a company establishing a plantation to commit only $21 \%$ of the overall investment from its own funds (Barr 2000; Barr et al. 2010). An ambitious smallholder timber plantation program (Hutan Tanaman Rakyat) was also launched in 2006. This program sought to develop 5.4 million ha of timber smallholdings by 2016 (Obidzinski and Dermawan 2010). It was to be supported by a range of incentives including low-interest loans, streamlined application procedures, assistance with land acquisition and simplified reporting. These smallholdings were expected to reduce demand on natural forests and to provide raw materials for Indonesia's timber processing industry (Obidzinski and Dermawan 2010).

More recently, industrial timber plantation development has also been promoted via a memorandum of agreement between the Ministry of Forestry and the South Korean Forest Service to establish timber plantations for wood pellet production (see Section 2 for further information).

\section{Production}

According to the Food and Agriculture Organization, Indonesia produced 6.4 million tonnes of wood pulp, 3.3 million tonnes of plywood and around 4.2 million tonnes of sawn timber in 2011. However, it is highly unlikely that all of these timber products solely originated from Indonesias industrial timber plantations, as the industry is heavily reliant on natural forest (Barr 2000). Statistics on the production of industrial timber plantations do not exist, or are at least difficult to locate. A study carried out in 2005 estimated that around $80 \%$ of 


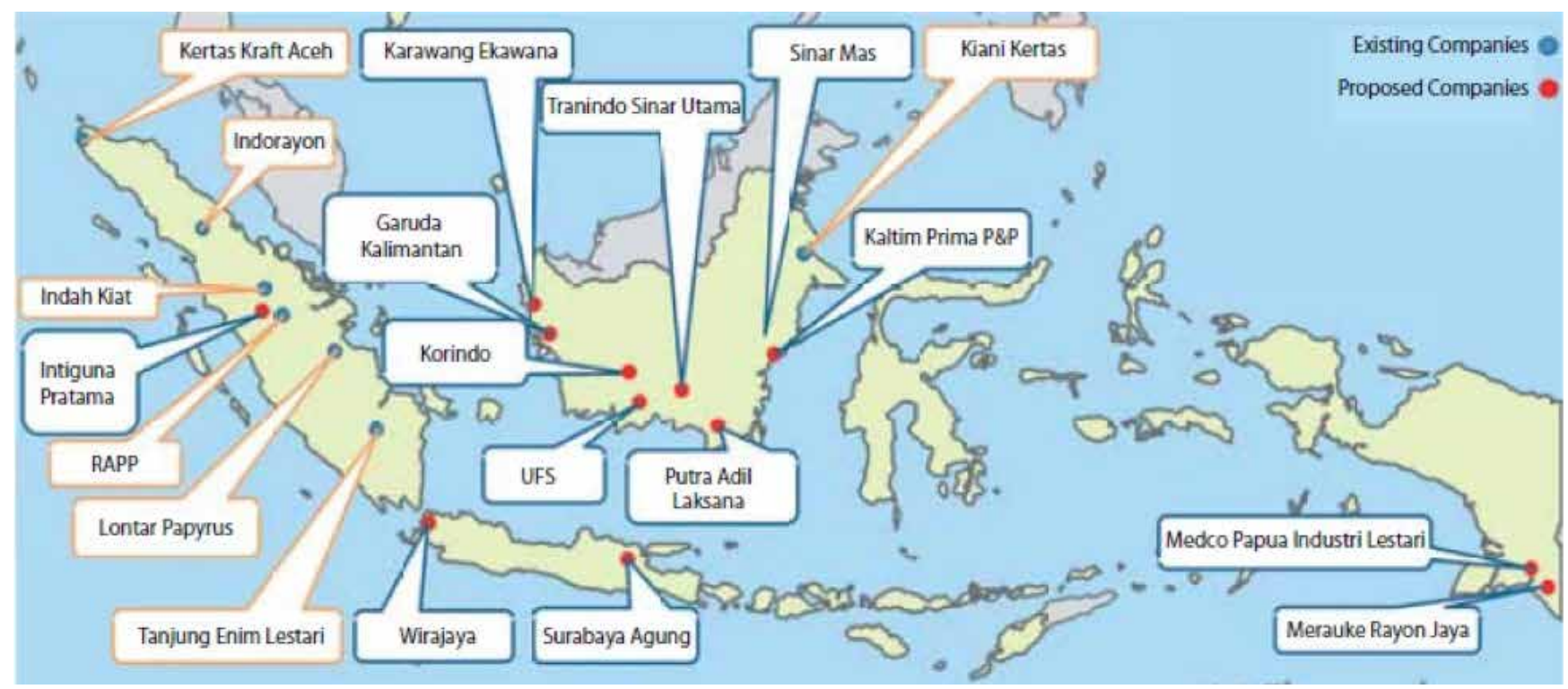

Figure 6. Existing and planned pulp and paper mills in Indonesia.

Source: Verchot (2010).

the timber utilized by the pulp and paper sector came from natural timber sources and only $20 \%$ from industrial timber plantations (Jurgens 2007). Another recent study estimated that pulp and paper producers in Riau, Sumatra, source more than half of their raw material from the conversion of natural forest (IWGFF 2011). Studies on industrial timber plantations have determined that they are poorly stocked and have limited productivity (Barr et al. 2010). Productivity has been affected by forest fires, limited finance and social conflict (Pirard and Cossalter 2006). Barr (2007) reviewed the sustainability action plan of Asia Pulp and Paper and determined that its pulp mill consumed around 1.85 million air-dried tonnes per year and was only able to supply $50 \%$ of its fiber needs from its timber plantation base. The mean annual increment from these plantations was $23.2 \mathrm{~m}^{3} /$ ha/year on mineral soils and $19.6 \mathrm{~m}^{3} /$ ha/year on peat soils. This meant that an additional 252,828 ha would be needed to sustain Asia Pulp and Paper's mill at its current consumption level. Much of this additional land was to be secured in Riau's peat swamp forest

(Barr 2007).

\section{Consumption}

Statistical data on the consumption of products originating from industrial timber plantations are difficult to locate. Available data on exports of pulp and paper, plywood and sawn timber indicate that Indonesia consumes almost all of the sawn timber it produces; however, it only consumes around 33\% of its pulp and paper production and around $46 \%$ of its plywood production (BPS 2012). The remaining pulp, paper and plywood production was exported.

\section{Economic significance}

The industrial timber sector has generated significant economic benefits in terms of employment, foreign exchange and contributions to GDP. For instance, the World Agroforestry Center and the Indonesian Climate Change Council have estimated that the labor requirements of pulpwood plantations during growing and harvesting phases were around 0.336 people per hectare (Ekadinata et al. 2010). The establishment phase requires around 3.1 people per hectare (ITS 2011). These numbers indicate that around 15 million people have been employed to establish 5.1 million ha of industrial timber plantations and that around 1.7 million people would have been employed in 2011 to care for and harvest these plantations. These estimates do not include indirect or flow-on employment. Researchers estimate an employment multiplier for the forestry sector of 41 jobs created for every 1 billion rupiah (IDR) invested in the industry (ITS 2011).

In 2011, Indonesia exported around 67\% of its pulp and paper production (primarily to Japan, Malaysia, Vietnam and the United States) and around 54\% of its plywood production (primarily to Japan, China, Saudi Arabia and Taiwan). Only around $1 \%$ of its sawn timber production was exported, primarily 
to Japan, China and Malaysia (BPS 2012). These exports contributed significantly to foreign exchange earnings; it is estimated that the export value of the pulp and paper sector was around USD 5.7 billion in 2011, while the export earnings of the plywood sector were estimated to be worth USD 1.95 billion in the same year.

The pulp and paper industry contributes around 1.2\% to Indonesia's GDP (ITS 2011). The development of large-scale pulp and paper operations (including industrial timber plantations) also provides significant benefits at the provincial level. A recent study (ITS 2011) found that Asia Pulp and Paper and Sinar Mas Forestry contribute around $0.9 \%$ of Indonesias GDP. The two companies also directly employ approximately 399,000 people on a full-time basis, and their forestry operations provide approximately 252,000 full-time-equivalent jobs annually for plantation establishment. Their pulp and paper exports make up around $2 \%$ of Indonesias nonmineral exports.

In Riau in particular, the contributions of Asia Pulp and Paper and Sinar Mas Forestry are more pronounced. It is estimated that the two companies generate $11 \%$ of all provincial economic output, employ $5.6 \%$ of the total workforce, contribute $3 \%$ of Riau's tax revenue, and generate $4.6 \%$ of all household income. Asia Pulp and Paper's operations in Riau alone make up around $1.3 \%$ of all of Indonesia's nonmineral exports (ITS 2011).

\section{Expected growth rates}

Global demand for pulp and paper, plywood and other wood products, such as wood pellets, is expected to expand over the next few years. For instance, paper demand is expected to increase by $2.1 \%$ per year in the long term, from 350 million tonnes in 2004 to 490 million tonnes by 2020 . Much of the increase in demand will come from China, India and Russia (ITS 2011).

Indonesia's pulp and paper industry is well positioned to capitalize on this increasing demand. Its advantages include the abundance of land, surplus labor, raw material supply, closeness to the Asian market, lower transportation costs and the appropriate climate for fast-growing trees. These factors make Indonesia one of the most costcompetitive producers in the world. Nevertheless, Indonesia is well behind on its plantation targets, and timber plantations are considered to be poorly stocked (Barr et al. 2010).
In June 2006, the Ministry of Forestry established a Forest Industry Revitalization Working Group. The resulting road map for the revitalization of the industry included a detailed action plan for the restructuring, re-engineering and revitalization of the nation's wood-based industries and called for the expansion of Indonesia's industrial plantation base to fill the supply gap for timber and pulpwood (Barr et al. 2010) The Ministry of Forestry consequently announced that it would promote the development of 9 million ha of new timber and pulpwood plantations by 2016; 3.6 million ha were to be developed by industrial timber plantation companies and 5.4 million ha by smallholders in communitybased plantations (butan tanaman rakyat) (Barr et al. 2010; Obidzinski and Dermawan 2012). The vast majority of these plantations are supposed to be established on degraded forest lands.

The Indonesian government's 2030 National Forestry Masterplan, formulated in 2011, also set out ambitious planting targets. The plan aims to increase the forestry sector's contribution to national GDP by $300 \%$ and increase the industrial timber plantation area to 14.7 million ha by 2030 (Obidzinski and Dermawan 2012). Plans for the establishment of seven new pulp mills with a capacity of nearly 5 million tonnes have also been released (Obidzinski and Dermawan 2012). These new mills are to be established in South Sumatra, East Kalimantan, Papua, West Kalimantan and East Kalimantan by dominant group companies such as Barito, Sinar Mas, Korindo, Djarum and Medco (Bisnis Indonesia 2011).

Area expansion may also be encouraged by a ministerial decision to reopen the export market for logs originating from industrial plantations. This decision is still pending, but the Ministry of Forestry is seriously considering it to stimulate growth in the industrial plantation sector. Only eucalyptus and acacia timber will be allowed to be exported if the decision goes through (Lubis 2013).

Between 2006 and 2011, around 1.68 million ha of industrial timber plantations were planted, which means that another 7.32 million ha of industrial timber plantations need to be planted in the next five years to reach the 2016 target. Around 1.4 million ha of industrial timber plantations needed to be planted per year to meet the 2016 target; however, only around 300,000 ha of industrial timber plantations were planted per year between 2006 and 2011. Clearly, Indonesia has fallen far 
behind on its target of establishing 9 million ha of industrial timber plantations by 2016. Based on current plantation expansion rates (approximately 300,000 ha per year), it is likely that an additional 1.5 million ha will be planted with industrial timber plantations by 2016 .

\section{Sugarcane}

Indonesia's sugar industry dates back to the 17 th century and peaked in the early 1930s, when 179 factories produced nearly 3 million tonnes of sugar annually (FAO 1998). The industry then experienced a decline as low sugar prices prevailed and there were only 35 factories producing about 500,000 tonnes of sugar. During World War II there were around 93 factories producing about 1.5 million tonnes; however, production declined again at the end of the war: only 30 factories remained, and production was less than 300,000 tonnes. During the 1950s some recovery occurred and Indonesia again became a net sugar exporter. However, since 1967 Indonesia has reverted to a net importer position. In 1957, the industry was nationalized and it has been highly regulated since then (FAO 1998).

Indonesia primarily produces white sugar from sugarcane for direct human consumption. Indonesia also produces refined sugar from imported raw sugar, which is generally used for processing by the food and beverage industries. More recently, molasses, a by-product of sugarcane, has been used in bioethanol production (Slette and Meylinah 2012).

\section{Area expansion}

From 1990 to 2011, the sugarcane plantation area expanded only marginally (around $1.14 \%$ per year), from 363,968 ha in 1990 to 451,788 ha in 2011 . It expanded by around 22\% from 1990 until 1996, when it peaked at $446,533 \mathrm{ha}$; it then began to decline as sugar prices dropped. During this period, governmentowned sugarcane plantations have declined in area or been converted to other crops. An estimated 71,252 ha was planted in government-owned sugar plantations in 1990 , but only 67,020 ha remained in 2011. Private sugarcane plantations expanded from 32,839 ha in 1990 to 106,035 ha in 2011. Smallholdings only expanded marginally, from 259,977 ha in 1990 to 278,733 ha in 2011 (Directorate General of Estates 2012) (Figure 7).

Sugar smallholdings currently dominate the sugar sector in Indonesia. In 2011, they made up 61.69\% or 278,733 ha of the country's total sugar cultivation area of 451,788 ha, with private plantations making up $23.47 \%$ or 106,035 ha and state plantations 67,020 ha or $14 \%$. Smallholdings used to be developed under the Nucleus Estate and Smallholders (NES) scheme, with large private or government plantations as the nucleus. Later, farms expanded outside the scheme (Directorate General of Estates 2012).

Before 2000, dominant large sugarcane plantations were primarily state owned, such as PT Perkebunan Nusantara X and XI in East Java. However, privately owned sugar companies such as PT Sugar Group (which holds 94,000 ha), PT Rajawali Nusantara Indonesia, PT Kebon Agung and PT Gunung Madu have expanded over the past decade (Slette and Meylinah 2012).

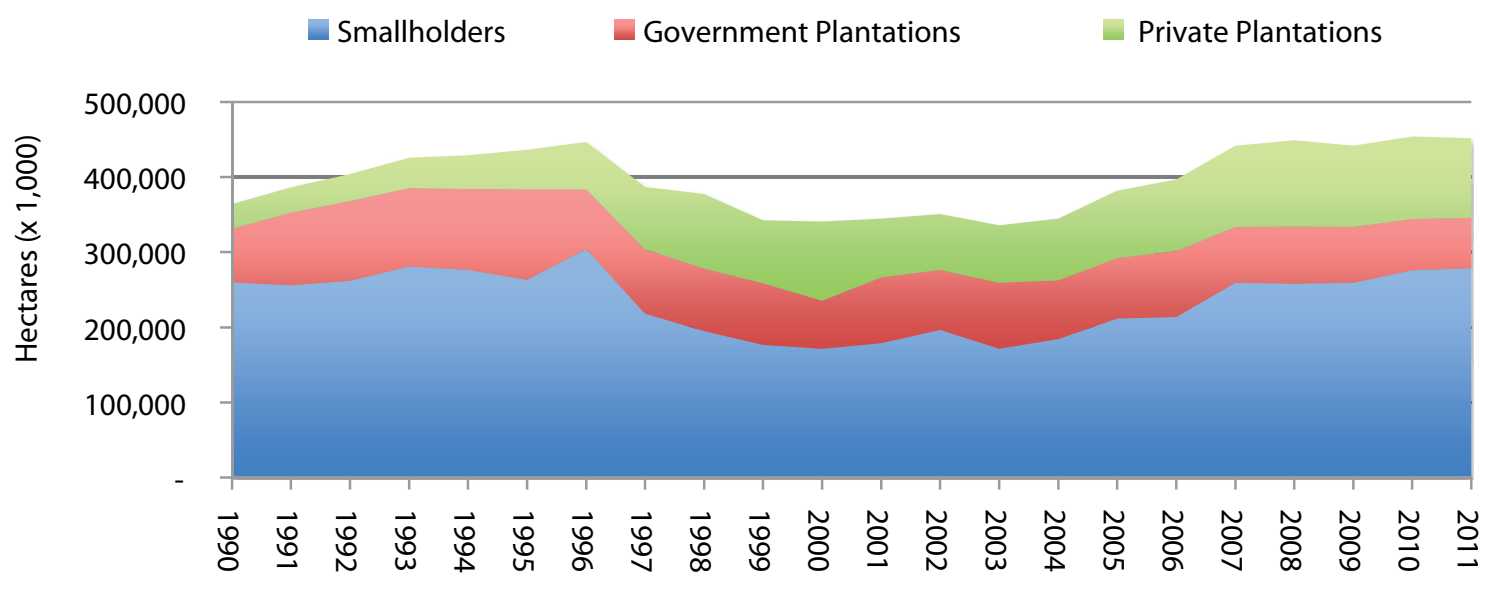

Figure 7. Area of sugarcane smallholdings and government and private plantations, 1990-2011. Source: Directorate General of Estates $(2012,3)$. 
Box 1. Dominant sugar companies in Indonesia

- PT Sugar Group Companies has three sugar production-based companies: PT Gula Putih Mataram, PT Sweet Indo Lampung, and PT Indo Lampung Perkasa. It produced the first branded sugar in Indonesia, Gulaku. Its sugar factories are integrated with sugar plantations totaling 94,000 ha in Lampung.

- PT Perkebunan Nusantara XI was established in 1996 through a merger of PT Perkebunan XX (Persero) and PT Perkebunan XXIV-XXV (Persero). It operates sugar plantations and a factory in East Java. Its landholdings total 69,516 ha. End products include granulated/refined sugar, molasses, alcohol and spirits.

- PT Rajawali Nusantara Indonesia was established in 1964 and was formerly Oei Tiong Ham Concern, one of the first conglomerates in Indonesia. It operates in agro-industry, pharmaceuticals and medical instruments and trade. A holding company with 15 subsidiaries, it has 35 branch offices, 10 sugar factories, two alcohol plants, one pharmaceutical factory, two health equipment factories, an oil palm plantation and a tea plantation. Its sugar plantations are located on 52,461 ha of land in West Java, Yogyakarta and East Java.
In the past, sugar plantations were concentrated in Java, but now plantations have been opened in Sulawesi and Sumatra. There used to be some sugarcane plantations in South Kalimantan; however, these farmers have switched to oil palm or other crops. Available data suggest that 12 companies have been allocated concessions totaling 420,000 ha in the Merauke Integrated Food and Energy Estate in Papua. If these plantations are successful, Indonesia's total sugarcane area will double.

In $2011,72 \%$ of Indonesia's sugarcane plantations were located in the provinces of East Java ( $47 \%$ or $192,587 \mathrm{ha}$ ) and Lampung ( $25 \%$ or $117,405 \mathrm{ha})$. The remaining plantations were primarily found in Central Java ( $14 \%$ or 65,519 ha), North Sumatra $(4.7 \%$ or 21,444 ha) and South Sumatra (4.3\% or 19,749 ha). Only $2.9 \%$ (13,171 ha) of Indonesia's sugarcane plantations were in South Sulawesi (Directorate General of Estates 2012, 6).

Throughout Indonesia, sugarcane plantation area expanded between 1995 and 2011 primarily in the provinces of Lampung, Gorontalo, South Sumatra and East Java. There was a decline in plantation area in South Kalimantan, North Sumatra, West Java, South Sulawesi, North Sulawesi, Daerah Istimewa Yogyakarta, Central Java and Nusa Tenggara Barat (Figure 8). It is most likely that sugarcane plantations have been converted to other crops, such as oil palm, in these provinces.

\section{Production}

In 2011, Indonesia only produced 2.26 million tonnes of sugarcane (Directorate General of Estates 2012) or $1 \%$ of total world production (estimated to be 172 million tonnes of sugarcane). Around 7000 metric tonnes of sugar molasses was used for bioethanol production in 2009; however, there has not been any ethanol production since then (Slette and Wiyono 2012). Sugarcane has had to compete with other crops, especially rice and palm oil. Less attractive returns as compared to other crops have continued to discourage some farmers from growing cane, leaving some factories without sufficient raw materials to operate at capacity.

Major world producers of sugarcane are Brazil, India, the EU and China. Along with Indonesia, other minor producers of sugarcane are Thailand, the United States (US), Mexico, Russia, Pakistan and Australia (Figure 9). Indonesia is not a major world producer of sugarcane, and it relies on sugar imports to meet domestic demand.

Several government schemes have been implemented to encourage sugarcane production, including the 1975 Smallholder Sugarcane Intensification Programme and the 1981 Induced Increasing Sugar Production Programme (Nelson and Panggabean 1991). At present, the government provides financial assistance to growers in various forms - for example, to support production, harvesting and hauling costs through the koperasi unit desa (rural cooperative unit). Some funds also flow through the factories to assist with fertilizer and chemicals.

A program promoting self-sufficiency, known as Swasembada Gula, was also launched in 1999. The Ministry of Agriculture set a target of self-sufficiency by 2014 at 5.7 million tonnes. This was to be made up of 2.96 million tonnes of white sugar and 2.74 million tonnes of refined sugar crystals. However, this target was reduced to 3.1 million tonnes in 2012 because it had been difficult to find suitable land for new sugar plantations (Rosalina 2012). Only 2.26 million tonnes of sugarcane was produced in 2011 (Directorate General of Estates 2012), which is far from the target of 3.1 million tonnes. 


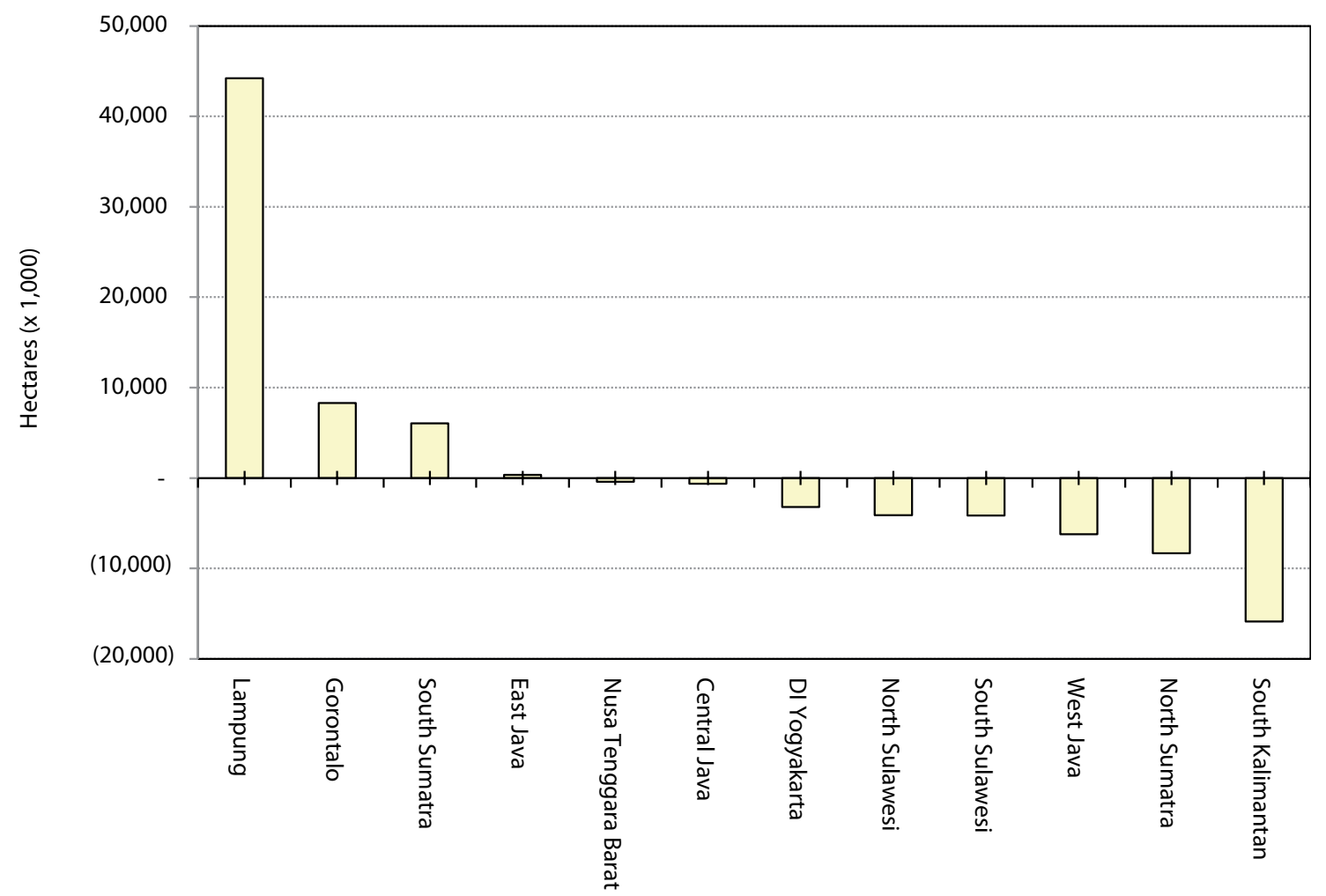

Figure 8. Sugarcane plantation area change by province, 2011.

Source: Directorate General of Estates $(2012,6)$.

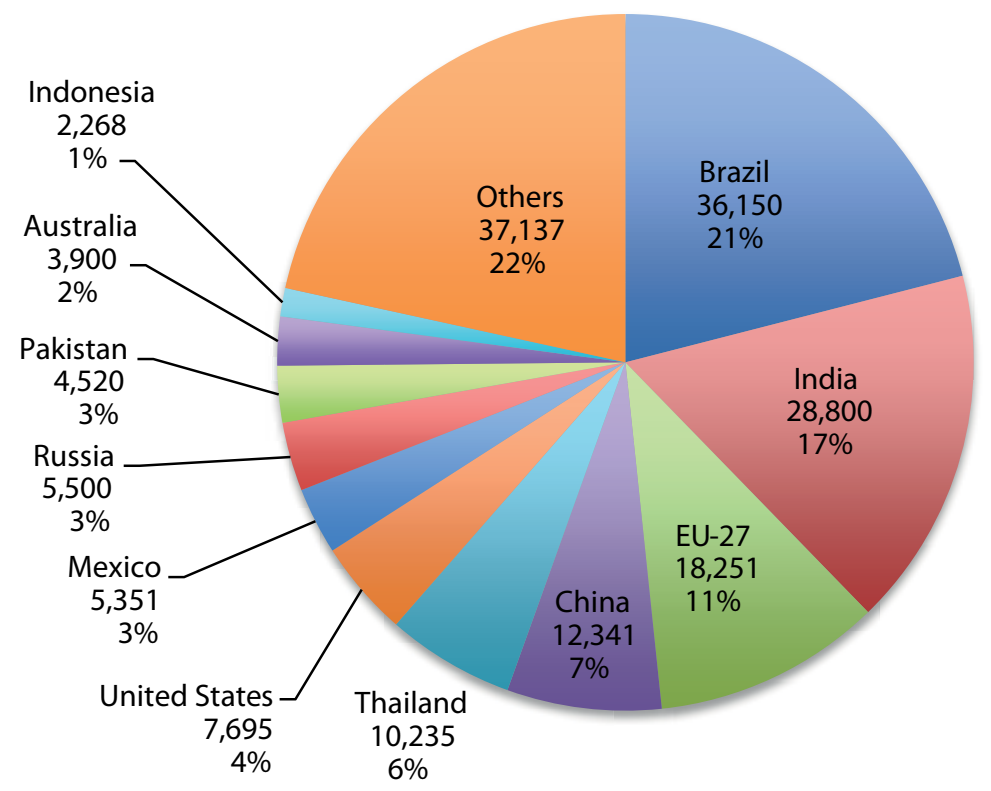

Figure 9. World producers of sugarcane, 2011 (thousand tonnes). Sources: Directorate General of Estates (2012); USDA (2012b). 
In 2008, the Indonesian government also launched the sugar machine revitalization scheme to support efforts to reach the target of sugar self-sufficiency by 2014. This program provided a $10 \%$ discount for any purchase of a new machine with a maximum price of IDR 10 billion (USD 1.1 million). The government provided a total of IDR 2.6 trillion (USD 288 million) to fund this program. The sugar factories have absorbed approximately $53.09 \%$ of the budget; however, Indonesia is still far from reaching the target of sugar self-sufficiency by 2014 (Slette and Meylinah 2013).

A number of policies, launched by the Indonesian government to promote biofuel development, have also stimulated investment in sugarcane plantations. For instance, Presidential Instruction No. 1/2006 mandated governors and districts to allocate land for biofuel stocks such as sugarcane; and Ministry of Agriculture Decree No. 26/Permentan/ Ot.140/2/2007 allows companies to acquire up to 150,000 ha of land for sugarcane plantations or 300,000 ha if the land is in Papua. Minister of Finance Decree No. 79/PMK.05/2007 also enables small- and medium-scale sugarcane companies to obtain subsidized financing.

\section{Consumption}

Between 1996 and 2012, sugar consumption in Indonesia increased from 2.75 million tonnes to 5.13 million tonnes (Slette and Meylinah 2012). Domestic consumption of sugar is growing in Indonesia along with population growth and GDP growth. Over the last few decades, there has been growing demand for sugar and for food items containing sugar such as confectionery and beverages. About $90 \%$ of sugar is used directly by households and $10 \%$ by industry. Refined sugar is imported largely for industrial use. Ethanol produced from sugar molasses has not been consumed in Indonesia since 2010, when ethanol production ceased after the price of molasses increased and ethanol became economically unviable (Abdi and Slette 2012).

Close to half of the world's sugarcane was consumed in India, the EU, China, Brazil and the US in 2011/2012. Minor consumers of sugarcane include Russia, Indonesia, Mexico, Pakistan and Egypt (Figure 10).

To meet growing demand, Indonesia imported around 2.3 million tonnes of sugarcane in 2011 (Figure 11). Most of it came from Thailand, Brazil and Australia. The value of these imports was estimated at USD 1.63 million. BULOG or Badan

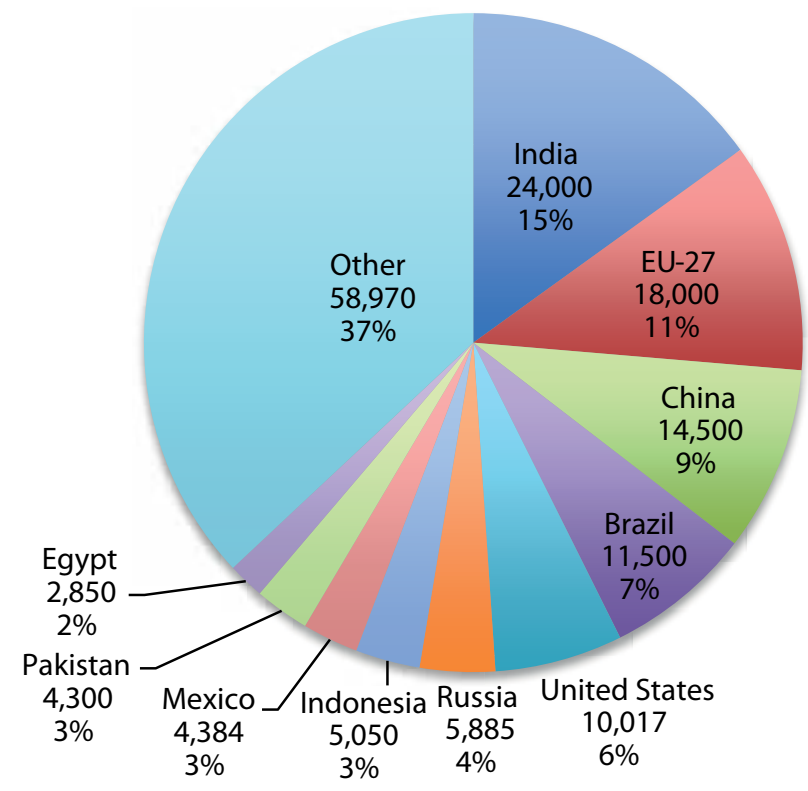

Figure 10. Global consumption of sugarcane, 2011/2012 (thousand tonnes).

Source: USDA (2012b).

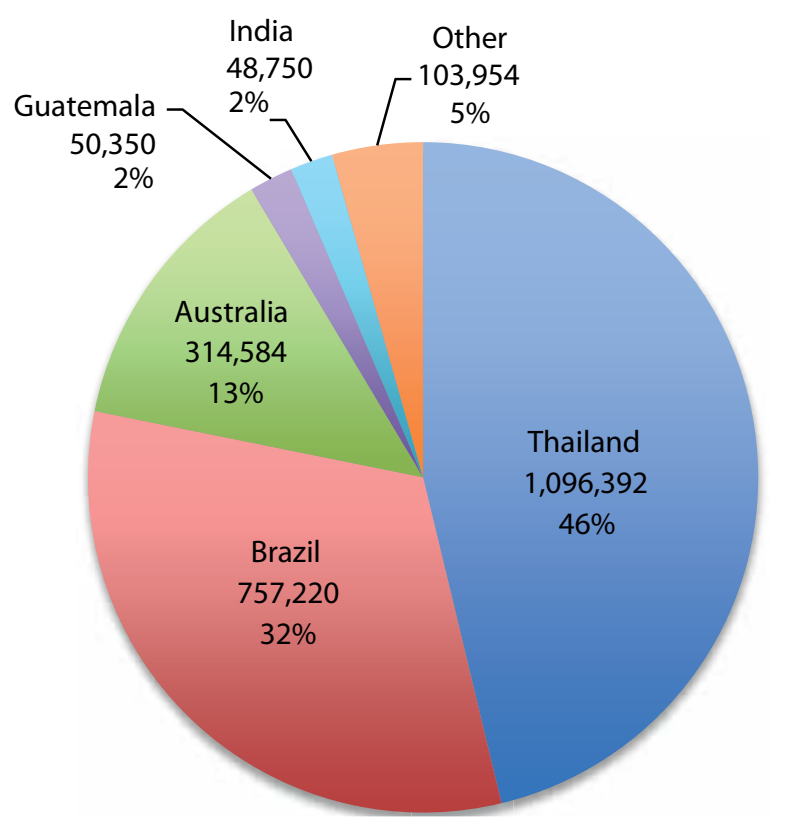

Figure 11. Sources of Indonesia's sugarcane imports, 2011 (tonnes).

Source: BPS (2012).

Urusan Logistik or the Bureau of Logistics is legally the sole importer of sugar and does not pay an import tariff. About five Indonesian firms, and a few international sugar traders, liaise with this state-owned enterprise to handle importation, for which a license is needed (FAO 1998; Slette and Meylinah 2012). 


\section{Economic significance}

The economic significance of sugarcane is relatively small compared with oil palm and industrial timber plantations, although sugar is considered a strategic commodity, employing around 900,000 farmers and about 1.3 million laborers per year (Dillon et al. 2008).

Indonesia only exports a small amount of sugarcane and relies on sugar imports to meet domestic demand. In 2011, Indonesia only exported approximately 686 tonnes of sugarcane - primarily to Malaysia, the US and Japan (Figure 12). The value of these exports was estimated at USD 788,000.

\section{Expected growth rates}

Demand for sugar is expected to continue to increase in line with population growth and rising incomes. However, the sugar industry is currently struggling to meet demand, and imports of sugar are likely to increase.

It has been reported that the Indonesian Ministry of Agriculture's Directorate General of Estate Crops has provided licenses for opening new sugarcane plantations, totaling about 215,000 ha, in Riau, Lampung, South Sulawesi, Central Java, East Java, South Sulawesi, West Kalimantan and Papua. Expansion is expected to occur first in Java and Lampung, where most sugarcane is already planted (Slette and Meylinah 2012).

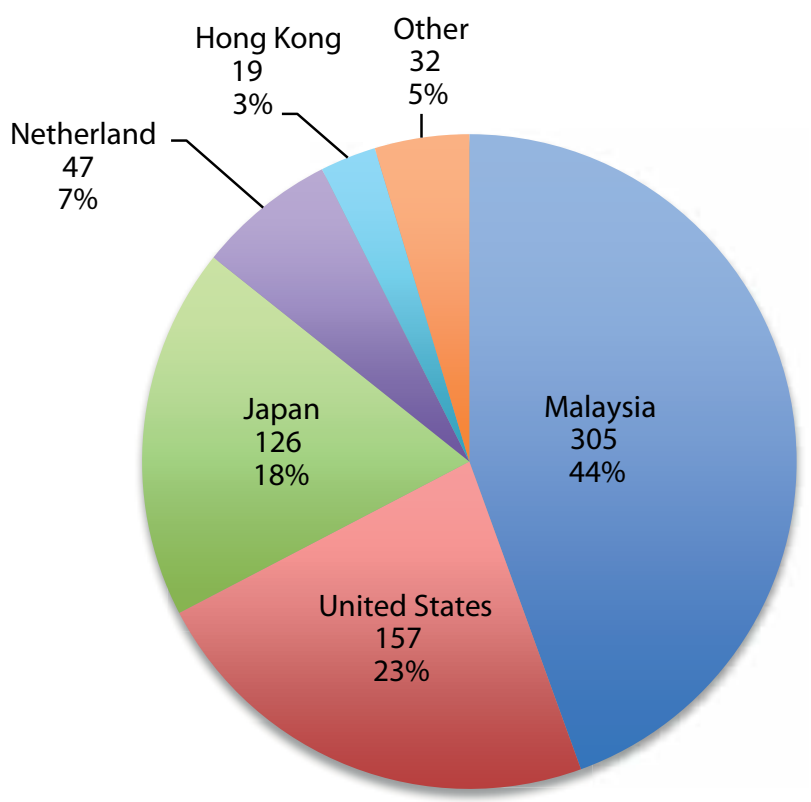

Figure 12. Indonesian exports of sugarcane, 2011 (tonnes).

Source: BPS (2012).
A number of large holding companies and groups such as Bakrie Group, Medco Group and Wilmar Group have also acquired around 420,000 ha of land to develop sugar plantations and factories in the Merauke Integrated Food and Energy Estate, which is to be developed in Papua. However, efforts to develop new sugarcane plantations outside of Java may be hindered by the lack of supporting infrastructure and by land ownership problems.

\section{Cassava}

Cassava (Manihot esculenta) is a woody shrub native to South America. It is now cultivated as an annual crop in tropical and subtropical regions for its edible, starchy, tuberous root, a major source of carbohydrates. Cassava is the third most important source of carbohydrates in the tropics after rice and maize. It is one of the most drought-tolerant crops and is capable of growing on marginal soils. Cassava plays a particularly important role in agriculture in developing countries, especially in sub-Saharan Africa, because it does well on poor soils and with low rainfall, and because its wide harvesting window allows it to act as a famine reserve. It also offers flexibility to resource-poor farmers because it can serve as either a subsistence or a cash crop (Prakesh 2005).

Cassava was introduced to most parts of Asia in the late 18th and early 19th centuries. After its introduction, it was initially used primarily as a food for local consumption. It was cultivated mainly on marginal lands, by poor farmers who often used it as an emergency crop. By the second half of the 19th century, domestic use of cassava was firmly established in Indonesia (Onwueme 2002).

In Indonesia, fresh cassava roots are utilized for direct human consumption. Most of the production is processed into chips and pellets, which are exported as animal feed (Onwueme 2002). More recently, cassava has also been considered as a feedstock for bioethanol due to its high yield of starch, adaptability to low-fertility soil and drought resistance (Sugiono and Mayrowani 2009).

\section{Area expansion}

Cassava plantation area has fluctuated considerably in Indonesia since 1993, when approximately 1.38 million ha had been planted. Cassava area increased by around $2 \%$ per year until 1996 when it peaked at 1.4 million ha; however, it has since declined, to around 1.18 million ha in 2011 (Figure 13). 


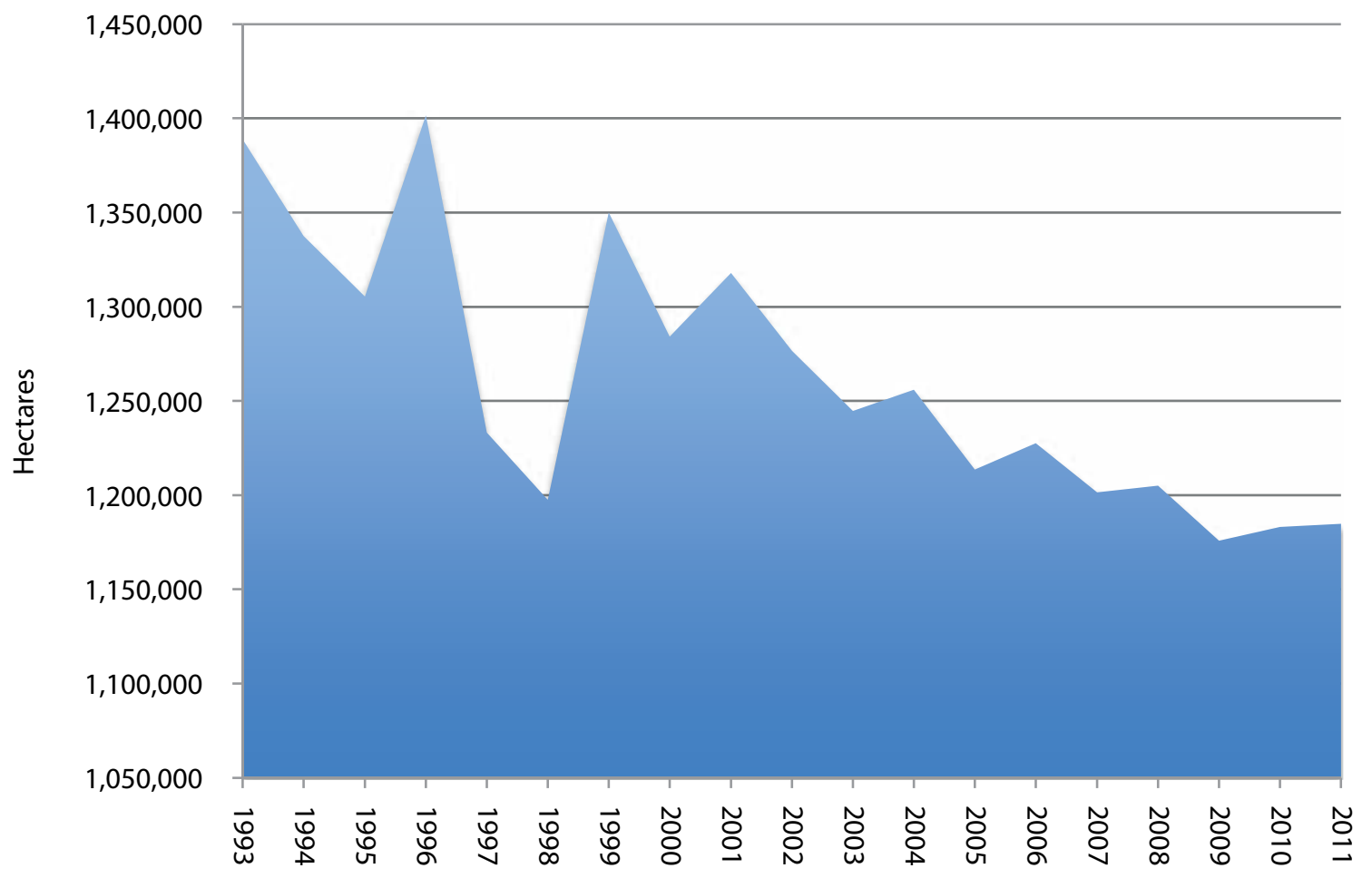

Figure 13. Cassava plantation area, 1990-2011.

Source: BPS (2012).

Most of Indonesia's cassava plantations are in the provinces of Lampung (31\% or 368,096 ha), East Java (16.83\% or 199,407 ha), Central Java (14\% or $173,195 \mathrm{ha})$, Nusa Tenggara Timur $(8.16 \%$ or $96,705 \mathrm{ha})$, Daerah Istimewa Yogyakarta $(5.25 \%$ or $62,414 \mathrm{ha})$ and West Java (8.71\% or $103,244 \mathrm{ha})$. In other words, around $45 \%$ of Indonesia's cassava plantations are on the island of Java and around $38 \%$ on the island of Sumatra. The remainder are primarily located in Kalimantan (1.7\% or 20,178 ha) and Sulawesi. Small plantations have been opened up in Papua, Nusa Tenggara Barat and Bali (BPS 2012).

Between 1993 and 2011, the area planted to cassava has grown in only 11 provinces, primarily in Lampung, Nusa Tenggara Timur, North Maluku and North Sumatra. It has declined in most provinces, particularly in East Java, Central Java, West Java, South Sulawesi and South Sumatra (Figure 14). Generally speaking, the most fertile lands, which are usually the lowlands, are reserved for rice, and cassava cultivation occurs on the less fertile hillsides (Onwueme 2002).

\section{Production}

Even with the reductions in planted area, Indonesia in 2011 was the third largest producer of cassava in the world. The other producers in the top seven were Nigeria, Brazil, Thailand, the Democratic Republic of Congo, Angola and Ghana. Close to half of the global crop comes from Africa (Figure 15).

While cassava is primarily produced for food in Indonesia, there has been some interest in using it to produce E10, a blend of cassava-based ethanol and gasoline (Restianti and Gheewala 2012). Cassava was targeted as one of the key biofuel crops that could be developed in Indonesia by the government's biofuel road map as envisioned in the Presidential Regulation No. 5/2006 on Indonesia's National Energy Policy. According to this road map, cassava plantations were to be developed for ethanol production in Java, Merauke and South Sumatra (Dermawan et al. 2012).

Nevertheless, the environmental merits of cassavabased ethanol have been questioned, because coal is generally used to generate power in ethanol conversion plants. A life-cycle analysis of cassavabased ethanol production in Indonesia concluded that it only has modest emissions savings (Restianti and Gheewala 2012). Ethanol also ceased to be produced in Indonesia in 2009 (Slette and Wiyono 2012). 


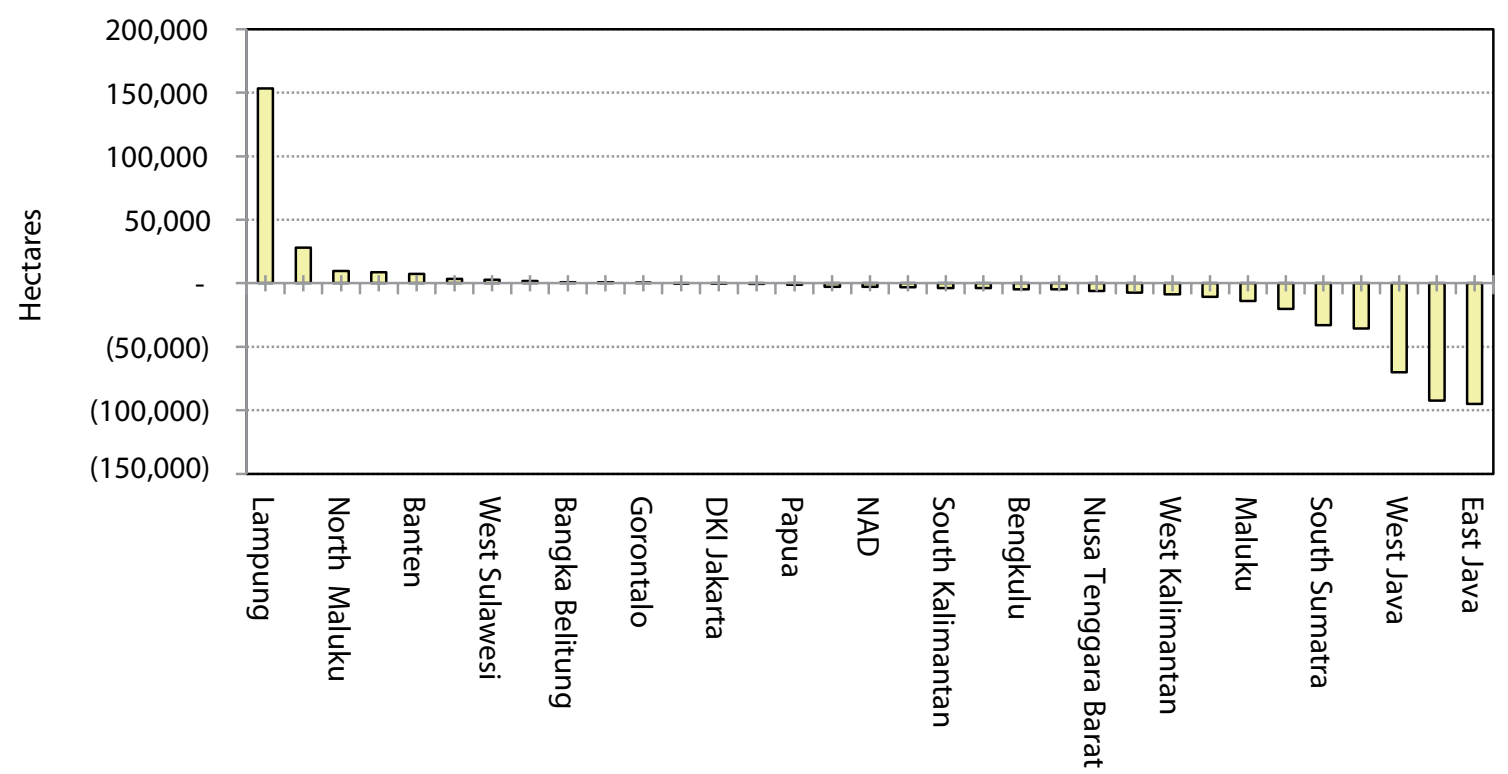

Figure 14. Cassava plantation area change by province, 2011.

Source: BPS (2012).

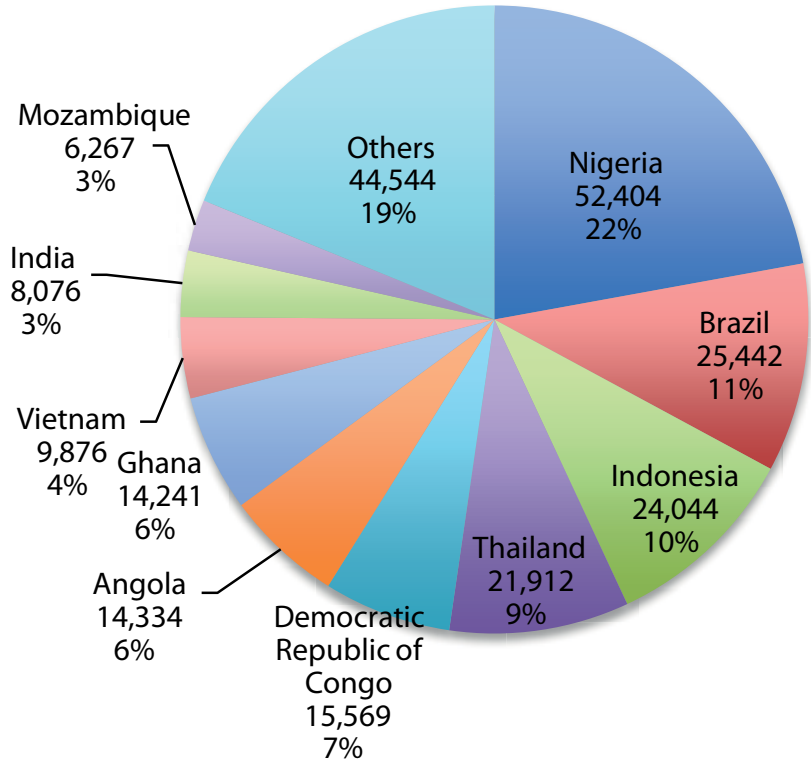

Figure 15. Global producers of cassava in 2011 (thousands of tonnes).

Source: BPS (2012).

\section{Consumption}

Cassava is the fourth most important food crop in Indonesia after rice, maize and soybeans (Onwueme 2002). About $70 \%$ of Indonesian cassava production is used for human food, in both the fresh form and a dried chip form called Gaplet (Onwueme 2002; Dillon et al. 2008). Both cassava roots and leaves are suitable for human consumption; the first are an important source of carbohydrates and the second of proteins and minerals (Prakesh 2005). Cassava roots are fried or boiled or fermented to make tapai and getuk cake, while the starch is made into krupuk crackers. In times of famine or food shortage, cassava is eaten in place of rice (Van der Eng 1998).

The second most important use of cassava is as feed for pigs, poultry, cattle and farmed fish (Prakesh 2005). While feed cassava products face competition from grains on international markets, cassava feed use is expanding quickly, particularly in Asia, where income growth is boosting the demand for and production of livestock products (Onwueme 2002).

Cassava starch is used as a raw material in a wide range of food products and industrial goods, including paper, cardboard, textiles, plywood, glue and alcohol. Four to five tonnes of roots are normally required to produce one tonne of cassava starch, but the ratio may be as high as ten to one, depending on the quality of the root. Cassava starch use is not dominant in Indonesia (Prakesh 2005).

Recently, cassava was also identified as a potential feedstock for ethanol production (Dillon et al. 2008). The government had ambitious plans for ethanol production from cassava. The Ministry of Agriculture's 2006 Action Plan aimed to establish an additional 1.36 million ha of cassava to produce 32 million tonnes of fuel ethanol by 2025 (Dillon et al. 2008). These plans are not on track as fuel ethanol ceased to be produced in Indonesia in 2009 (Slette and Wiyono 2012). 
Cassava has several advantages over crops such as irrigated rice. It can be grown on poor soils and steep slopes, making it ideal for cultivation in upland fields where the water supply is insufficient for rice cultivation; it is a hardy plant and largely drought resistant. Cassava also does not require much attention during growth and can be left in the ground for 6 to 24 months and harvested at will to suit the labor supply, market conditions or household requirements (Van der Eng 1998).

Cassava also has some disadvantages. It tends to exhaust the soil quickly, especially when cultivated on poor soils, so that long fallow periods and fertilizers are required. The fresh tuber can also only be kept for up to three days as it deteriorates quickly after being harvested. The protein-calorie ratio is also low, and several cassava varieties contain a high quantity of prussic acid, which is poisonous to humans. The poisonous substance disappears if the cassava is processed into tapioca (Van der Eng 1998).

\section{Economic significance}

The bulk of world trade in cassava is in the form of pellets and chips for animal feed (70\%), and the balance is mostly in starch and flour for food processing and industrial use. Very little is traded in the form of fresh root, given the product's bulkiness and perishable nature. Thailand is the biggest exporter, accounting for some $80 \%$ of global trade; Vietnam and Indonesia each export about $8 \%$; and a few countries in Asia, Africa and Latin America provide the remainder (Onwueme 2002; Prakesh 2005). Most of Indonesia's cassava exports go to the EU; however, China is emerging as a leading cassava importer (Prakesh 2005). Cassava can be used to produce ethanol, but this has been rare in Indonesia and, as mentioned earlier, ethanol production ceased in 2009 (Slette and Wiyono 2012).

\section{Expected growth rates}

There is growing recognition of the importance of cassava as a staple crop, a resource in the fight against hunger and poverty, and an export commodity for developing countries. Lack of institutional support and competition from cereals in food consumption, animal feed and industrial uses are the main obstacles to the further development of cassava. Under prevailing low international cereal prices, there is considerable pressure for cassava production and processing costs to be reduced if the crop is to gain a greater market share (Prakesh 2005). Biofuels could be a future growth market for cassava, but there has been little interest in this feedstock for biofuel production in Indonesia to date (Prakesh 2005).

\section{Jatropha}

Jatropha (Jatropha curcas) is a succulent shrub or tree originating in Central America. It is widely cultivated in many tropical and subtropical areas, including Africa, where it is used as a hedge plant. The nonedible oil from the seeds can be used to make candles and soap, while the remaining seed cake can produce biogas or be used as fertilizer or animal feed if detoxified. The oil can also be refined into biodiesel to fuel vehicles (Pohl 2010).

In the mid 2000s, jatropha was hailed as a particularly suitable crop for biofuels because it can grow on arid, barren lands and, being inedible, does not compete with food production. In Indonesia, the government promoted the establishment of jatropha in Java, Kalimantan, Nusa Tenggara, Papua, Sulawesi and Sumatra as part of its program to promote energy self-sufficiency in villages (Caroko et al. 2011). However, the crop has recently attracted much criticism and is no longer considered the miracle crop it was thought to be (Pohl 2010). Studies have shown that high yields are dependent on good soil and chemical additives. Growing the crop on marginal land leads to marginal yields, and more land is consequently required to produce a profit. Jatropha has also been found to compete for land with food crops and create unwanted sideeffects around the globe. A life-cycle study conducted by researchers at the Yale School of Forestry also determined that jatropha biofuel, like other biofuel crops, cannot be 'carbon positive' if cultivation results in leveling forests or plowing up native vegetation (Bailis and Baka 2010).

\section{Area expansion}

Statistics on jatropha are hard to come by, primarily because jatropha is not a food crop and is poorly documented. Jatropha began to be planted in Indonesia in 1975 in East Java and Nusa Tenggara. Planted area has fluctuated significantly since then, with a peak in 2001. (Planted area and production levels are summarized in Table 9.) In the mid-2000s, Indonesian scientists, the Indonesian government and investors were enthusiastic about jatropha's potential as a biofuel (MoA 2013). However, in 2009, when global oil prices dropped, the government stopped pushing jatropha development, and the global financial crisis deterred investment. Planted area began to increase again after the financial crisis subsided.

Jatropha development has also been hindered by poor and inconsistent yields (Pohl 2010). A study conducted in North Sumatra concluded that 
Table 9. Jatropha cultivation area and production, 1990-2011.

\begin{tabular}{lrc}
\hline Year & Area (ha) & Production (tonnes) \\
\hline 1990 & 6,690 & 2,020 \\
1991 & 6,086 & 1,804 \\
1992 & 5,235 & 1,836 \\
1993 & 5,234 & 1,686 \\
1994 & 2,336 & 991 \\
1995 & 2,909 & 1,001 \\
1996 & 10,782 & 1,335 \\
1997 & 11,157 & 1,186 \\
1998 & 18,817 & 4,259 \\
1999 & 15,482 & 1,800 \\
2000 & 12,807 & 1,504 \\
2001 & 21,347 & 2,908 \\
2002 & 9,617 & 2,229 \\
2003 & 12,978 & 2,225 \\
2004 & 8,154 & 1,713 \\
2005 & 6,169 & 995 \\
2006 & 6.043 & 917 \\
2007 & 6,000 & 1,000 \\
2008 & 5,300 & 2,300 \\
2009 & 3,100 & 1,500 \\
2010 & 3,800 & 1,700 \\
2011 & 4,100 & 1,700 \\
\hline
\end{tabular}

Source: MoA (2013).

jatropha is a much less economically promising crop for smallholders than oil palm due to its long payback period and low rates of return (Verner et al. 2012). This has been confirmed by other analysts who have determined that palm-oil-based biodiesel is significantly cheaper to produce than jatropha-based biodiesel (Slette and Wiyono 2012). Due to its low profits, a practically nonexistent export market and inadequate infrastructure for production, Indonesia's confidence in jatropha is not high.

\section{Production}

Although enthusiasm for jatropha has declined since 2007, with most major projects on hold, some analysts continue to maintain that Indonesia is ideal for small-scale jatropha production because it fits the Indonesian model of many small-scale producers (Perry 2010). Some investors also continue to believe that jatropha is a viable biofuel crop and to pursue jatropha production. For instance, PT Alegria Indonesia completed construction of a plant that can produce biofuel from jatropha in 2010. The plant was equipped with a processing unit to produce 10,000 liters of biofuel daily. It requires 48,000 tonnes of dried jatropha seeds per month, and local farmers in the Pasuran administration have been encouraged to cultivate jatropha on degraded land in order to meet demand (Boediwardhana 2010). Eco Emerald is also planning to establish 10,000 ha of jatropha in the districts of Jayapura and Biak-Numfor in the province of Papua. Around 600 ha of jatropha had been planted by the end of 2011 (EcoEmerald 2012).

Nevertheless, jatropha is considered a marginal crop in Indonesia and farmers have largely been unsuccessful in planting it (Dermawan et al. 2012).

\section{Consumption}

Data on jatropha consumption are not available, primarily because jatropha is not edible and thus is not included in statistics on food crops. Data on how much jatropha is being used in biodiesel are also not available, but since less area has been planted to jatropha than to oil palm, it can be assumed that the contribution of jatropha to biodiesel production and consumption is minimal.

\section{Economic significance}

Economic data on jatropha are not available, primarily because jatropha is not a food crop. Several researchers have promoted jatropha as a wonder crop that has great potential to create income for the rural poor (Silitonga et al. 2011). It is relatively cheap to plant and cultivate and requires fewer labor inputs than other crops. However, its long payback period and low rates of return make jatropha less economically promising for smallholders than oil palm (Verner et al. 2012). Biodiesel producers have also opted for less expensive palm oil as a feedstock, so smallholders growing jatropha have been left with limited markets for their product.

\section{Expected growth rates}

As described above, enthusiasm for jatropha has diminished and most major projects are on hold (Perry 2010). If jatropha is to be grown on an industrial scale, its oil yields will need to be vastly enhanced through conventional plant breeding or genetic manipulation so that it can compete with other biofuel feedstocks. 


\section{Summary}

Significant area expansion has occurred only for oil palm and industrial timber plantations (Table 10). Sugarcane has also seen a small expansion, but Indonesia is heavily reliant upon sugar imports to meet domestic demand for sugar in food and beverages. Area planted to jatropha and cassava has declined over the past 20 years, and recent interest in biofuels has not stimulated these sectors to grow. Industrial timber plantations have expanded the most, but the largest area of land has been dedicated to oil palm.

Oil palm expansion has primarily occurred in the provinces of Riau, Central Kalimantan, South Sumatra, West Kalimantan, North Sumatra, Jambi and East Kalimantan. It is also thought that industrial timber plantation expansion has primarily occurred in Riau, South Sumatra, North Sumatra and East Kalimantan, where Indonesia's largest pulp and paper mills have been established. This could mean that the pulp and paper mills have secured timber supplies from the clearing of land in these regions to make way for oil palm.

Both the oil palm and industrial timber sectors have created important economic benefits for Indonesia. The oil palm sector generated export earnings valued at USD 13.46 billion (around 2.5\% of GDP) in
2010; and the pulp and paper industry contributed around $1.2 \%$ of GDP in the same year. The oil palm sector was estimated to employ 2.9 million people, while the pulp and paper sector is employing around 1.7 million people to grow and harvest timber.

Oil palm and industrial timber cultivation are both expected to expand, with the oil palm area expected to reach 15.2 million ha in 2025 and the industrial timber plantation area expected to reach around 9.1 million ha by 2016 . Both sectors have been expanding significantly over the last few years - oil palm plantations by around 400,000 ha and industrial timber plantations by around 300,000 ha per year. Most expansion is expected to occur in Sumatra and Kalimantan, with some expansion in Papua, particularly in forests allocated for conversion or on land falling outside the stateowned forests.

Other biofuel feedstocks such as jatropha, cassava and sugarcane are not expected with expand significantly over the next decade unless large-scale food and biofuel estates such as the Merauke Food and Energy Estate are successful. These crops perform poorly when compared to oil palm and have not proven to be economically profitable.

The following section will discuss the use of these feedstocks in Indonesia's emerging biofuel sector.

Table 10. Planted area, 1990-2011.

\begin{tabular}{lcccc}
\hline & $\mathbf{1 9 9 0}(\mathbf{0 0 0} \mathrm{ha})$ & $\mathbf{2 0 1 1}(\mathbf{1 0 0} \mathrm{ha})$ & Change, $\mathbf{1 9 9 0 - 2 0 1 1 ( 1 0 0 ~ h a )}$ & Change per year \\
\hline Oil palm & 1,300 & 8,900 & 7,600 & $28 \%$ \\
Timber & 131.7 & 5,100 & 4,960 & $179 \%$ \\
plantations & 6.7 & 4.1 & -2.6 & $-1.84 \%$ \\
Jatropha & 1.380 & 1,180 & -0.200 & $-0.69 \%$ \\
Cassava $^{\mathrm{a}}$ & 364 & 451.8 & 87.8 & $1.14 \%$ \\
Sugar & & & & \\
\hline
\end{tabular}

a The figure in the 1990 column is for 1993.

Note: Oil palm, timber plantations, jatropha and cassava areas are used for food, cosmetics and other products as well as for biofuel. Jatropha is mainly produced for biofuel. 


\section{Bioenergy developments in Indonesia}

Despite the recent global recession, Indonesia has experienced relatively strong economic performance, with an average GDP growth rate of just below $7 \%$ per year over the past 10 years (MEMR 2012). Population has increased by about $1.5 \%$ per year, from $205,843,000$ to $241,134,000$ between 2000 and 2011. Today, Indonesia is the fourth most populous country in the world (behind China, India and the US) and the most populous country in Southeast Asia (PRB 2012). Strong economic growth and expanding population mean there is increasing demand for energy and a need to secure long-term energy supplies.

Indonesia's total primary energy consumption grew by around 43\% between 2000 and 2011 (Table 11 and Table 12). In 2011, fuel (predominantly petroleum) and other petroleum products met $38 \%$ of Indonesia's energy needs. Coal is increasingly being used as an energy source, and consumption has more than quadrupled over the past 11 years. Coal consumption has surpassed that of natural gas, which was the third most consumed energy source in Indonesia until 2010 (MEMR 2012).
At current production rates, Indonesia's proven reserves for crude oil and natural gas are estimated to last for 23 years and 52 years, respectively (Bromokusumo 2007; Hasan et al. 2012). The production level of Indonesian oil has already started to decline, and imports of oil are required to meet demand (Caroko et al. 2011).

To meet its energy needs, offset its dependence on fossil fuels and take advantage of the emerging global market for bioenergy, Indonesia has been keen to expand bioenergy production, consumption and exports. The country is well positioned to develop bioenergy as it already has extensive oil palm plantations and is now the world's leading producer of CPO.

In 2006, the Indonesian government pledged that biofuels would make up $2 \%$ of the energy mix by 2010 and $5 \%$ by 2025 . It also instructed 13 central and regional government institutions to promote the establishment of a domestic biofuel industry by allocating land for biofuel development and offering incentives to potential investors. Several

Table 11. Energy consumption, 2000-2011 (thousand BOE, barrel of oil equivalent).

\begin{tabular}{rrrrrrrrrrr}
\hline Year & Biomass & Coal & \multicolumn{1}{c}{$\begin{array}{l}\text { Natural } \\
\text { gas }\end{array}$} & $\begin{array}{l}\text { Petroleum- } \\
\text { based } \\
\text { fuel }\end{array}$ & $\begin{array}{l}\text { Other } \\
\text { petroleum } \\
\text { products }\end{array}$ & Briquette & LPGa & Electricity & Total \\
\hline 2000 & 269,042 & 36,060 & 87,214 & 315,272 & 13,435 & 85 & 8,261 & 48,555 & 777,925 \\
2001 & 268,953 & 37,021 & 82,235 & 328,203 & 25,712 & 78 & 8,280 & 51,841 & 802,325 \\
2002 & 270,207 & 38,698 & 80,885 & 325,202 & 22,688 & 83 & 8,744 & 53,418 & 799,926 \\
2003 & 271,974 & 68,264 & 90,277 & 321,384 & 23,533 & 77 & 8,766 & 55,473 & 839,748 \\
2004 & 271,765 & 55,344 & 85,459 & 354,317 & 37,716 & 80 & 9,187 & 61,393 & 875,261 \\
2005 & 270,043 & 65,744 & 86,634 & 338,375 & 29,614 & 94 & 8,453 & 65,644 & 864,261 \\
2006 & 276,271 & 89,043 & 83,221 & 311,913 & 41,126 & 94 & 9,414 & 69,071 & 880,153 \\
2007 & 275,126 & 121,904 & 80,178 & 314,248 & 39,873 & 89 & 10,925 & 74,376 & 916,720 \\
2008 & 277,874 & 94,035 & 102,281 & 320,987 & 16,658 & 155 & 15,718 & 79,138 & 906,846 \\
2009 & 279,169 & 82,587 & 118,587 & 335,271 & 55,663 & 220 & 24,384 & 82,499 & 978,380 \\
2010 & 273,587 & 136,820 & 115,404 & 363,130 & 55,765 & 49 & 32,067 & 90,707 & $1,067,529$ \\
2011 & 280,050 & 144,567 & 121,234 & 363,827 & 69,978 & 66 & 37,046 & 97,998 & $1,114,767$ \\
\hline
\end{tabular}

a $L P G=$ liquefied petroleum gas.

Source: MEMR (2012). 
Table 12. Supply of primary energy (\%) excluding biomass, 2000-2011.

\begin{tabular}{lrrrrrrrrrrrr}
\hline Type of energy & $\mathbf{2 0 0 0}$ & $\mathbf{2 0 0 1}$ & $\mathbf{2 0 0 2}$ & $\mathbf{2 0 0 3}$ & $\mathbf{2 0 0 4}$ & $\mathbf{2 0 0 5}$ & $\mathbf{2 0 0 6}$ & $\mathbf{2 0 0 7}$ & $\mathbf{2 0 0 8}$ & $\mathbf{2 0 0 9}$ & $\mathbf{2 0 1 0}$ & $\mathbf{2 0 1 1}$ \\
\hline Oil & 59.64 & 57.20 & 56.62 & 53.16 & 57.08 & 55.07 & 51.30 & 49.58 & 48.84 & 47.61 & 47.10 & 47.74 \\
Coal & 12.91 & 15.43 & 15.36 & 19.20 & 17.37 & 19.37 & 22.89 & 27.01 & 22.82 & 23.29 & 24.35 & 27.03 \\
Gas & 22.66 & 22.28 & 23.61 & 23.76 & 21.49 & 21.33 & 21.86 & 19.21 & 23.99 & 24.72 & 23.36 & 21.17 \\
Hyrdropower & 3.47 & 3.80 & 3.13 & 2.67 & 2.79 & 3.02 & 2.70 & 2.98 & 2.95 & 2.82 & 3.80 & 2.53 \\
Geothermal & 1.32 & 1.29 & 1.28 & 1.21 & 1.27 & 1.22 & 1.24 & 1.20 & 1.36 & 1.47 & 1.27 & 1.33 \\
Biofuel & 0.00 & 0.00 & 0.00 & 0.00 & 0.00 & 0.00 & 0.01 & 0.02 & 0.03 & 0.08 & 0.12 & 0.19 \\
\hline
\end{tabular}

Source: MEMR (2012).

other government regulations were also established to stimulate investment and make it easier for investors to access land for the development of biofuel feedstocks. Biofuel development was expected to increase energy security and job creation, especially in rural areas (Dillon et al. 2008).

\section{Biofuel}

Biofuel is a generic term used to describe bioethanol, biodiesel and other biologically based liquid transport fuels such as biobutanol and biogas (WWF 2007), as well as other renewable fuel sources such as wood pellets. Two types of liquid fuel dominate the biofuel sector: biodiesel and bioethanol.

Biodiesel is produced primarily from triacylglycerol, a lipid obtained from soy, canola, coconut, jatropha, palm oil and other oilseeds and palm fruits.

Rendered animal fats, such as tallow and lard, and used cooking oil can also be converted to biodiesel (Dillon et al. 2008; Bailey 2013). Biodiesel can be blended with conventional diesel from fossil sources (WWF 2007). In Indonesia, palm oil is the primary feedstock used to produce biodiesel; the use of oil derived from jatropha has also been encouraged. Biodiesel is an oxygenated, sulfur-free and biodegradable fuel; its oxygen content helps improve its combustion efficiency. Life-cycle assessments have estimated that fewer GHGs such as $\mathrm{CO}_{2}$ are released into the atmosphere from biofuels provided these biofuels were not grown on previously forested or otherwise carbon-rich lands (Nagi et al. 2008).

Ethanol is an alcohol produced from plants such as sugarcane, sugar beet, corn, wheat and cassava. Processed bioethanol fuel can be used as an additive to gasoline (Dillon et al. 2008; Bailey 2013). In Indonesia, bioethanol has only been produced from molasses, a by-product of sugarcane.
Surging crude oil prices and growing concerns about global warming have encouraged many countries to promote the use of biofuels. For instance, the EU and the US administrations have established policies that reduce gasoline consumption and encourage the consumption of renewable fuels (Alvarez et al. 2010; Charles et al. 2013).

In 2011, the world's top producers of biofuel were the US, Brazil, Germany, France, Argentina and China. Indonesia, Spain and Thailand each produced around $1 \%$ of the world's biofuel (Figure 16). Biofuel production has steadily increased in all of these countries except for Brazil, where it fell between 2010 and 2011 (US Energy Information Administration 2011).

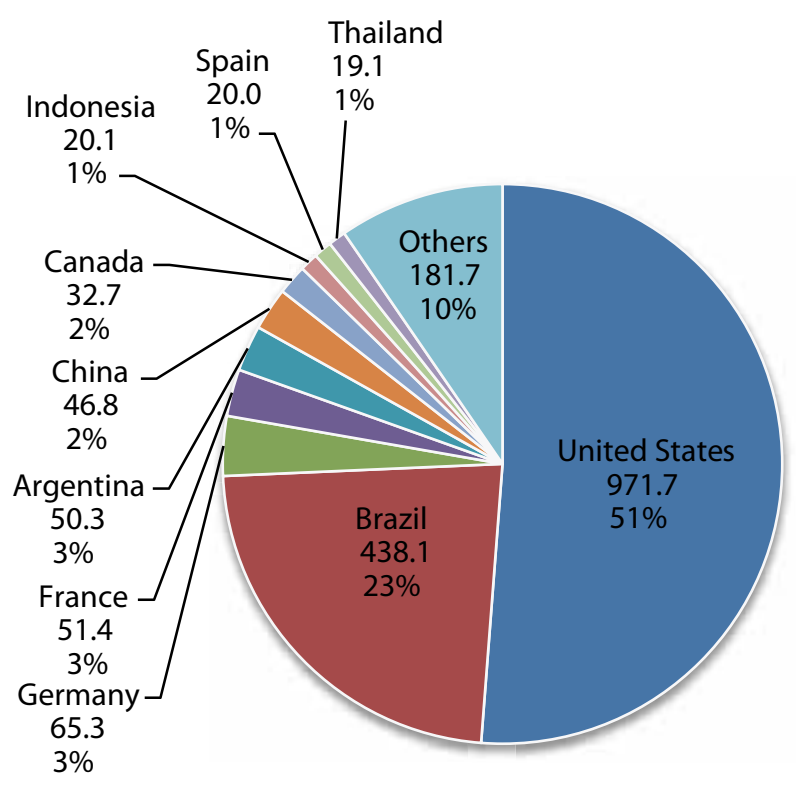

Figure 16. Global producers of biofuel, 2011 (millions of tonnes).

Source: US Energy Information Administration (2011). 
Indonesia is only a minor consumer of biofuel (Figure 17). The major consumers are the US, which consumes close to half of the world's biofuel production, Brazil, Germany, France, Canada, China, Spain, Italy, the United Kingdom and Poland (US Energy Information

Administration 2011).

In Indonesia, biofuel started to be sold in 2006 as BioSolar, BioPertamax and BioPremium through the state-owned oil company PT Pertamina. BioSolar is a mix of $2.5 \%$ biodiesel in the form of fatty acid methyl ester and $97.5 \%$ diesel fuel. BioPremium and BioPertamax are a mixture of 3\% ethanol and 97\% gasoline (Jupesta et al. 2011b). BioPremium, BioPertamax and Pertamax Plus used gasoline with an octane number of 88,92 and 95, respectively. BioPremium and BioPertamax production ceased in 2010, while BioSolar production has increased substantially (Table 13).

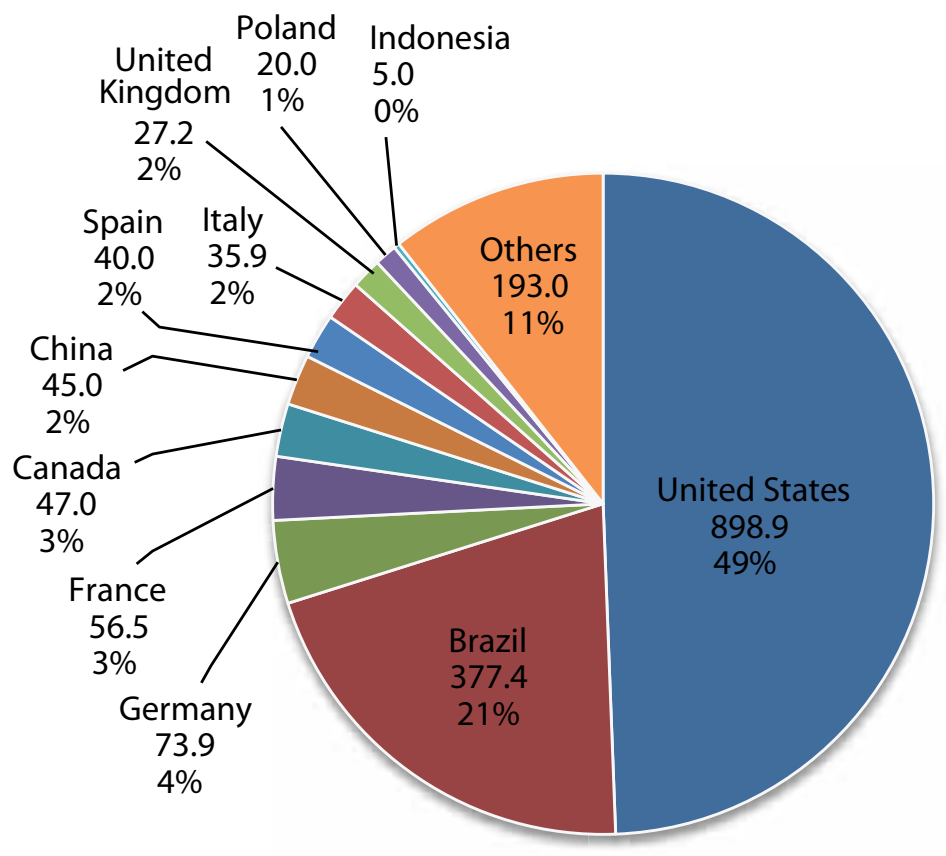

Figure 17. Global consumption of biofuel, 2011 (million of tonnes).

Source: US Energy Information Administration (2011).

Table 13. Fuel consumption in the transportation sector (kiloliters).

\begin{tabular}{lrrrrrr}
\hline & \multicolumn{1}{c}{$\mathbf{2 0 0 6}$} & \multicolumn{1}{c}{$\mathbf{2 0 0 7}$} & \multicolumn{1}{c}{$\mathbf{2 0 0 8}$} & \multicolumn{1}{c}{$\mathbf{2 0 0 9}$} & $\mathbf{2 0 1 0}$ & $\mathbf{2 0 1 1}$ \\
\hline BioSolar & 217,048 & 877,457 & 931,179 & $2,398,234$ & $4,393,861$ & $7,180,806$ \\
BioPremium & 1,624 & 55,970 & 44,016 & 105,816 & 0 & 0 \\
BioPertamax & 16 & 9,956 & 16,234 & 20,232 & 0 & 0 \\
Premium & $15,941,837$ & $16,962,198$ & $19,112,241$ & $20,802,405$ & $22,391,362$ & $24,766,975$ \\
Others* & $12,175,552$ & $12,661,198$ & $13,452,053$ & $16,261,624$ & $19,645,100$ & $20,897,370$ \\
\hline Total fuel & $28,117,389$ & $29,623,396$ & $32,564,294$ & $37,064,029$ & $42,036,462$ & $45,664,345$ \\
\hline
\end{tabular}

* include Avgas, Avtur, Pertamax, Pertamax Plus, Kerosene and fuel oil

Source: MEMR (2012). 


\section{Biodiesel}

\section{Production}

Indonesia was the sixth largest producer of biodiesel in the world in 2011, after the US, Germany, Argentina, Brazil and France (Figure 18). Indonesia's place as a major biodiesel producer only emerged in the last few years as its biodiesel production increased from just 8000 barrels (about 1.36 million tonnes) a day in 2010 to 20,000 barrels (about 3.4 million tonnes) a day in 2011. Prior to 2011, Spain, Italy and Thailand produced more biodiesel than Indonesia.

In Indonesia, palm oil is the primary feedstock used to produce biodiesel, because it is already well established and has the highest oil productivity per unit of land on earth (Table 4). Another potential feedstock is jatropha, but jatropha does not currently seem feasible for large-scale production in Indonesia because of its low yields and low extraction rates, and it has not proven able to compete with palm oil (Slette and Wiyono 2012). The area planted to jatropha has not increased and was just 4100 ha in 2011.

CPO biodiesel production in Indonesia has steadily increased. In 2006, there were two biodiesel plants in Indonesia with a production capacity of 215 million liters (about 189,929 tonnes); by 2012, there were 26 biodiesel plants with a production capacity of 4280 million liters (about 3.78 million tonnes) running at a capacity of $42 \%$ (Slette and Wiyono 2012). Production of biodiesel increased from 65 million liters (about 57,420 tonnes) in 2006 to 1800 million liters (about 1.6 million tonnes) in 2012. Consumption of CPO to produce biodiesel also increased from 64,000 tonnes in 2006 to 1.76

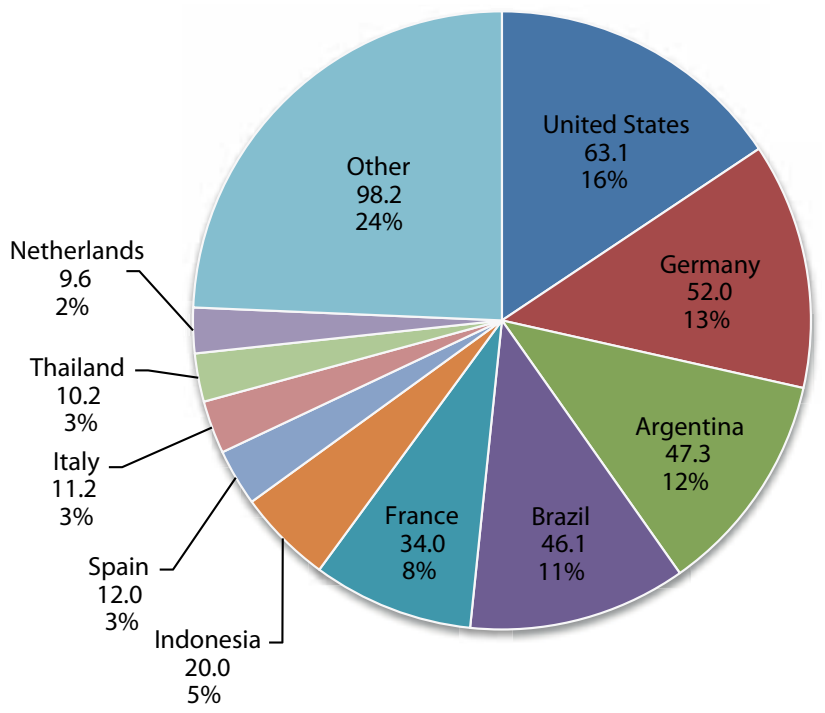

Figure 18. Global biodiesel production, 2011 (thousand barrels per day).

Source: US Energy Information Administration (2011).

million tonnes in 2012 (Slette and Wiyono 2012). This was around $7 \%$ of Indonesia's total estimated CPO production for 2011 (23.9 million tonnes). According to Bisinfocus (2012), the average yield for oil palm plantations in 2012 was 3.55 tonnes of CPO per hectare. This means that around 494,744 ha of Indonesia's oil palm plantations produced CPO for biodiesel production in 2011 - roughly $5.5 \%$ of Indonesias total oil palm area (estimated to be 8.9 million ha in 2011). Table 14 summarizes recent growth in biodiesel production and capacity.

While biofuel production is increasing, biorefinery capacity remains low. In 2012, biorefineries were only

Table 14. Biodiesel production and capacity (million liters), 2006-2013.

\begin{tabular}{lrrrrrrrr}
\hline & 2006 & $\mathbf{2 0 0 7}$ & $\mathbf{2 0 0 8}$ & $\mathbf{2 0 0 9}$ & $\mathbf{2 0 1 0}$ & $\mathbf{2 0 1 1}$ & $\mathbf{2 0 1 2}$ & $\begin{array}{l}\mathbf{2 0 1 3} \\
\text { (projected) }\end{array}$ \\
\hline Total production & 65 & 270 & 630 & 330 & 740 & 1520 & 1800 & 2200 \\
Exports & 33 & 257 & 610 & 204 & 563 & 1225 & 1300 & 1500 \\
Consumption & 5 & 22 & 23 & 60 & 220 & 304 & 500 & 700 \\
Production capacity & & & & & & & & \\
Number of biorefineries & 2 & 7 & 14 & 20 & 22 & 22 & 26 & 26 \\
Capacity (million liters) & 215 & 1709 & 3138 & 3538 & 3926 & 3936 & 4280 & 4280 \\
Capacity use & $30 \%$ & $16 \%$ & $20 \%$ & $9 \%$ & $19 \%$ & $39 \%$ & $42 \%$ & $51 \%$ \\
Feedstock use & & & & & & & & 1769 \\
CPO (1000 metric ton) & 64 & 265 & 619 & 324 & 727 & 1494 & 2162 \\
\hline
\end{tabular}

Sources: Slette and Wiyono (2012). 
operating at $42 \%$ of their capacity. The low use of refining capacity is partly the result of a decision by some companies to produce palm oil for food rather than for fuel.

\section{Consumption}

Globally, Indonesia is only a minor consumer of biodiesel, accounting for around $1 \%$ of global consumption in 2011 (Figure 19). Major global consumers of biodiesel are the US, Germany, France, Spain and Italy. Most of these countries source biodiesel from soybeans, rapeseed and sunflower oil rather than palm oil (Atabani et al. 2012).

Indonesia's domestic consumption of biodiesel expanded from 5 million liters (about 4416 tonnes) in 2006 to 700 million liters (about 618,374 tonnes) in 2011 (Slette and Wiyono 2012). Consumption is largely affected by government policy and the price of CPO. Pertamina is the only seller of biofuel for transportation at the retail level, and it sets the amounts of biodiesel and ethanol to be used in its blends. In 2006, Pertamina announced that it would decrease the amount of biodiesel and ethanol used in its blends from $5 \%$ to $2.5 \%$ when the price of CPO increased (Caroko et al. 2011). It was forced to decrease this further to 1\% in April 2008 (Dillon et al. 2008). However, it increased the biodiesel blending rate back to 5\% in February 2012. It also expanded the distribution of biodiesel to Kalimantan and Sulawesi in 2012 (Slette and Wiyono 2012). These improvements were expected to raise

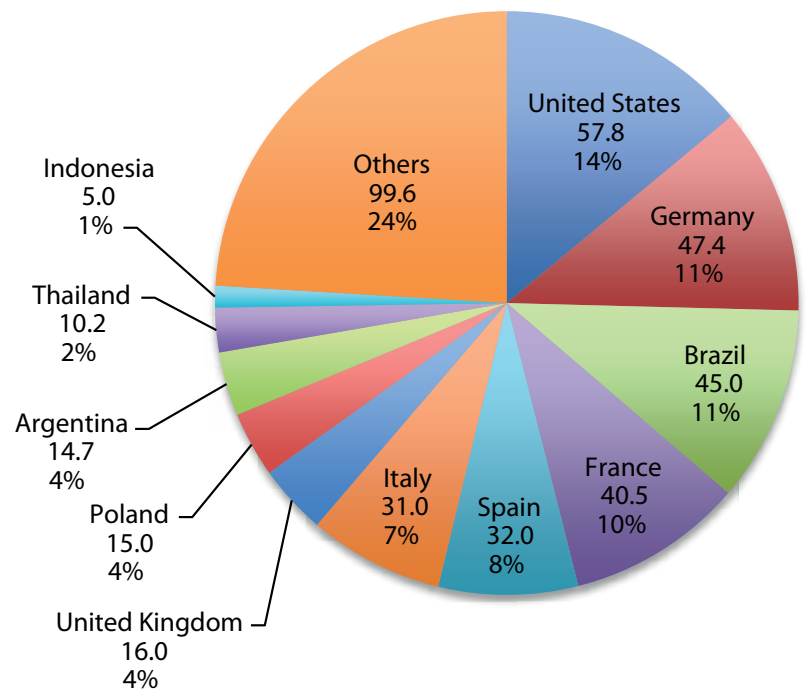

Figure 19. Global consumption of biodiesel, 2011 (million tonnes).

Source: Atabani et al. (2012). biodiesel consumption in the transportation sector. Consumption is also likely to increase since coal and mining companies are now obliged to achieve $2 \%$ of biofuel in their fuel mix (Slette and Wiyono 2012). Moreover, in 2013 the Indonesian Ministry of Energy and Mineral Resources and Parliament reached an agreement to provide biofuel subsidies at IDR 3000 per liter for biodiesel and IDR 3500 per liter for ethanol. These policies are beginning to show the potential to raise Indonesian biodiesel consumption (Slette and Wiyono 2012).

\section{Exports}

Low domestic consumption of biofuel has led the Indonesian government to allow biodiesel producers to export (Slette and Wiyono 2012). Indonesia exports biodiesel in the form of fatty acid methyl ester, to be blended with diesel in the destination country. In 2012, most of Indonesia's biodiesel production (72\%) was exported, primarily to China, the EU and the US (Slette and Wiyono 2012).

Exports of biodiesel are largely driven by the price of $\mathrm{CPO}$ on the world market. In fact, the biofuel option is often seen as a safety net for the palm oil sector, especially when the price of $\mathrm{CPO}$ is about to hit rock bottom and the palm oil stockpile sits above the critical 2 million tonne mark (Yulisman 2013).

\section{Bioethanol}

Bioethanol comes from anhydrous alcohol produced from the fermentation of sugarcane, cassava or corn. Up to $15 \%$ of the processed bioethanol fuel can be used as an additive to transportation fuel without the need for any special equipment (Dillon et al. 2008; Bailey 2013). In Indonesia, molasses, a by-product of sugarcane, is primarily used for bioethanol production. Sugarcane is thought to have one of the highest yields per hectare and to have one of the highest GHG savings compared with petrol (Table 15). Indonesian government and industry are also looking at cassava as a feedstock for ethanol; however, cassava is currently primarily produced for food, and the area planted to it has declined, from 1.38 million ha in 1993 to 1.18 million ha in 2011 (BPS 2012).

\section{Production}

The US and Brazil dominate the bioethanol fuel market, producing $87 \%$ of the world's supply. Until 2006, Brazil was the global leader in ethanol production, in large part due to the greater efficiency of sugarcane-based ethanol conversion. However, 
Table 15. Yield and greenhouse gas savings of bioethanol feedstocks.

\begin{tabular}{|c|c|c|c|}
\hline Crop & Annual yield & $\begin{array}{l}\text { Greenhouse gas } \\
\text { savings vs. petrol }^{\text {a }}\end{array}$ & Comments \\
\hline \multirow[t]{2}{*}{ Miscanthus } & 7300 liters/ha & \multirow[t]{2}{*}{$37 \%-73 \%$} & \multirow{2}{*}{$\begin{array}{l}\text { Low-input perennial grass. Ethanol production } \\
\text { depends on development of cellulosic technology. }\end{array}$} \\
\hline & 780 US gallons/acre & & \\
\hline \multirow[t]{2}{*}{ Switchgrass } & 3100-7600 liters/ha & \multirow[t]{2}{*}{$37 \%-73 \%$} & \multirow{2}{*}{$\begin{array}{l}\text { Low-input perennial grass. Ethanol production } \\
\text { depends on development of cellulosic technology. } \\
\text { Breeding efforts are underway to increase yields. } \\
\text { Higher biomass production is possible with mixed } \\
\text { species of perennial grasses. }\end{array}$} \\
\hline & $\begin{array}{l}330-810 \text { US gallons/ } \\
\text { acre }\end{array}$ & & \\
\hline \multirow[t]{2}{*}{ Poplar } & 3700-6000 liters/ha & \multirow[t]{2}{*}{$51 \%-100 \%$} & \multirow{2}{*}{$\begin{array}{l}\text { Fast-growing tree. Ethanol production depends on } \\
\text { development of cellulosic technology. Completion of } \\
\text { genomic sequencing project will aid breeding efforts } \\
\text { to increase yields. }\end{array}$} \\
\hline & $\begin{array}{l}400-640 \text { US gallons/ } \\
\text { acre }\end{array}$ & & \\
\hline \multirow[t]{2}{*}{ Sugarcane } & 6800-8000 liters/ha & \multirow[t]{2}{*}{$87 \%-96 \%$} & \multirow{2}{*}{$\begin{array}{l}\text { Long-season annual grass. Used as feedstock for most } \\
\text { bioethanol produced in Brazil. Newer processing } \\
\text { plants burn residues not used for ethanol to generate } \\
\text { electricity. Grows only in tropical and subtropical } \\
\text { climates. }\end{array}$} \\
\hline & $\begin{array}{l}727-870 \text { US gallons/ } \\
\text { acre }\end{array}$ & & \\
\hline \multirow{2}{*}{$\begin{array}{l}\text { Sweet } \\
\text { sorghum }\end{array}$} & 2500-7000 liters/ha & \multirow[t]{2}{*}{ No data } & \multirow{2}{*}{$\begin{array}{l}\text { Low-input annual grass. Ethanol production is } \\
\text { possible using existing technology. Grows in tropical } \\
\text { and temperate climates, but highest ethanol yield } \\
\text { estimates assume multiple crops per year (possible } \\
\text { only in tropical climates). Does not store well. }\end{array}$} \\
\hline & $\begin{array}{l}270-750 \text { US gallons/ } \\
\text { acre }\end{array}$ & & \\
\hline \multirow[t]{2}{*}{ Corn } & 3100-4000 liters/ha & \multirow[t]{2}{*}{$10 \%-20 \%$} & \multirow[b]{2}{*}{$\begin{array}{l}\text { High-input annual grass. Used as feedstock for most } \\
\text { bioethanol produced in the US. Only kernels can be } \\
\text { processed using available technology; development of } \\
\text { commercial cellulosic technology would allow stover } \\
\text { to be used and increase ethanol yield by } 1100-2000 \\
\text { liters/ha. }\end{array}$} \\
\hline & $\begin{array}{l}330-424 \text { US gallons/ } \\
\text { acre }\end{array}$ & & \\
\hline
\end{tabular}

a Savings assume no land use change (use of existing crop lands).

Sources: Sanderson (2006).

as a result of government policies and higher oil prices, ethanol production in the US has recently surged, and it now exceeds that in Brazil (Hertel et al. 2010) (Figure 20). Strong incentives, coupled with other industry development initiatives, are giving rise to fledgling ethanol industries in countries such as Australia, Canada, China, Columbia, France, Germany, India, Spain, Sweden, Thailand and some Central American countries (US Energy Information Administration 2011).

In spite of this surge of interest worldwide, bioethanol production is virtually nonexistent in Indonesia, although there was some investment between 2006 and 2009. In 2006, there was one refinery producing bioethanol from sugarcane molasses with production estimated at 300,000 liters (about 227 tonnes). Bioethanol production peaked in 2009, when 1.72 million liters (about 129,090 tonnes) of bioethanol was produced at five refineries. However, since 2010, there has been no production

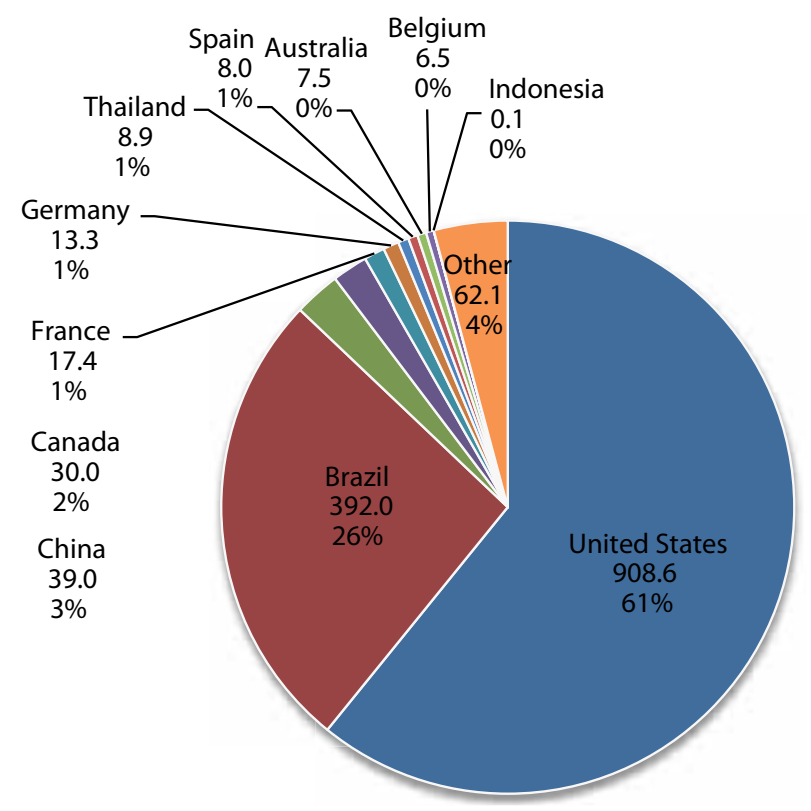

Figure 20. Global producers of bioethanol, 2011 (thousand barrels per day).

Source: US Energy Information Administration (2011). 
Table 16. Fuel ethanol production and capacity growth (million liters), 2006-2013.

\begin{tabular}{|c|c|c|c|c|c|c|c|c|}
\hline Calendar year & 2006 & 2007 & 2008 & 2009 & 2010 & 2011 & 2012 & 2013 \\
\hline Total production & 0.30 & 1.00 & 1.20 & 1.72 & 0 & 0 & 0 & 0 \\
\hline Consumption & 0.05 & 0.66 & 1.81 & 1.26 & 0 & 0 & 0 & 0 \\
\hline \multicolumn{9}{|l|}{ Production capacity } \\
\hline Number of refineries & 1 & 1 & 4 & 5 & 5 & 5 & 5 & 5 \\
\hline $\begin{array}{l}\text { Capacity } \\
\text { (million liters) }\end{array}$ & 10 & 13 & 243 & 273 & 273 & 273 & 273 & 273 \\
\hline Capacity use & $3 \%$ & $8 \%$ & $0 \%$ & $1 \%$ & $0 \%$ & $0 \%$ & $0 \%$ & $0 \%$ \\
\hline \multicolumn{9}{|l|}{ Feedstock use } \\
\hline Molasses (1000 MT) & 1 & 4 & 5 & 7 & 0 & 0 & 0 & 0 \\
\hline
\end{tabular}

Source: Slette and Wiyono (2012).

of bioethanol from these five refineries, which have a production capacity of 273 million liters (about 206,193 tonnes) (Slette and Wiyono 2012). Table 16 summarizes recent trends in fuel ethanol production and capacity.

Bioethanol production in Indonesia ceased in 2010, primarily because of the increasing price of molasses, the primary Indonesian ethanol feedstock. Domestic fuel ethanol prices and the government's ethanol subsidy of IDR 2000 per liter were not enough to keep producers' margins positive. The government is trying to rectify this situation by introducing a new biofuel price formula, which takes into account the fluctuation of feedstock prices including the price of molasses (Slette and Wiyono 2012). The new formula should enable Indonesian fuel ethanol producers to charge a price that covers production costs and still yields a profit (Slette and Wiyono 2012).

Ethanol production faces other challenges as well. Most sugar mills in Indonesia are less efficient stateowned enterprises, and many still use Dutch colonialera technology (Slette and Wiyono 2012). Alcohol is strictly prohibited in Indonesia for religious reasons, so sales of ethanol are heavily regulated with high tariffs and taxes. Moreover, the sugar cultivation area is not expanding significantly or able to meet domestic demand for sugar in food and beverages.

\section{Consumption}

Bioethanol has not been consumed in Indonesia since 2009. It was consumed as BioPremium and BioPertamax (a mix of 3\% ethanol and 97\% gasoline) between 2006 and 2009, when consumption reached 1.26 million liters (about 96,166 tonnes) (Slette and Wiyono 2012).
Most of the world's bioethanol is consumed by the US and Brazil. Minor consumers include Canada, China, Germany, France and the United Kingdom (US Energy Information Administration 2011). Most cars on the road today in the US can run on blends of up to $10 \%$ ethanol, and ethanol represented $10 \%$ of the US gasoline fuel supply in 2011. Since 1976 the Brazilian government has made it mandatory to blend ethanol with gasoline, and since 2007 the legal blend is around 25\% ethanol and $75 \%$ gasoline (Slette and Wiyono 2012). Bioethanol consumed in the US and Brazil is primarily produced from sugarcane.

\section{Biogas methane capture}

In addition to biodiesel and bioethanol production, there is limited yet growing use of biogas generated from methane capture in Indonesia. Biogas is primarily generated from palm oil mill effluent (POME), a thick brownish liquid that contains organic matter, solids, oil and grease. It is harmful to the environment if discharged untreated. The conventional industry method of processing POME is to keep it in open-air treatment ponds, subjected to anaerobic digestion. This process generates biogas containing approximately $65 \%$ methane (Igwe and Onyegbado 2007). Methane is now believed to be 34 times more potent as a green house gas than $\mathrm{CO}_{2}$ over a 100 -year timeframe and 84 times more potent over a 20 -year timeframe (IPCC 2013a); thus, the free emission of biogas into the atmosphere can adversely affect the sustainability and marketability of palm oil, especially in the biofuels sector. 
It has been estimated that $28 \mathrm{~m}^{3}$ of biogas is generated for every $1 \mathrm{~m}^{3}$ of palm oil waste in the waste treatment plants of palm oil mills (Mel et al. 2010). By tightly sealing an open digester system with a high-density polyethylene membrane or foil, methane gas could be captured and used to generate electricity at a rate of 1.7 kilowatt-hours per $1 \mathrm{~m}^{3}$ of gas (Mel et al. 2010). Electricity generated in this way could be used as an alternative to diesel fuel in the mills and estates.

Although biogas technology has existed since the 1970s, use of the technology with POME was quite slow until 2000 (Mel et al. 2010). According to the Indonesia Palm Oil Mill Board, only about $10 \%$ of mills are equipped with biogas power plants (Cahyat 2013). Some of the larger oil palm groups operating in Indonesia, especially those aspiring to Roundtable on Sustainable Palm Oil (RSPO) certification, are developing methane capture facilities. For instance, the Musim Mas Group fitted one of its palm oil mills in Pangkalan Lesung (Pekanbaru, Riau Province) with such a facility in 2010. According to Musim Mas, the fixed cost of this project is projected to be USD 3-4 million, with operating costs of 3-4 US cents per kilowatt-hour of electricity produced. An internal analysis conducted by the company concluded that it will take approximately 10 years to recover the investment costs for the methane digester, assuming that there is no income generated from carbon credits; the facility provides electricity for internal use, not the national energy grid (ZSL 2012). This was confirmed by Cahyat (2013), who argued that the cost savings from installing POMEbiogas facilities is not enough to attract investment, as installation requires high up-front investment and is considered to be a business risk. This effectively makes methane capture technology unviable for smallholders.

Currently in Indonesia, it is not possible for oil palm companies to provide electricity to the national energy grid, so the use of biogas generated from mill effluent cannot be traded; it can only be used to generate electricity within the mill and plant itself (ZSL 2012). This is because most palm oil processing mills are located in remote areas that are not connected to the power grid. Power is usually generated through steam turbine or diesel generators (Cahyat 2013). The Wilmar group had also established six methane capture facilities in its palm oil mills by the end of 2011. The recovered biogas was used in a boiler for steam for power generation (Wilmar 2011).
Methane capture meets Criterion 5.6 of the RSPO Principles and Criteria standards, and it is a key component of the mandatory Indonesian Sustainable Palm Oil (ISPO) Criteria and Indicators. The ISPO expects at least $60 \%$ of Indonesia's palm oil mills to install methane capture facilities by 2020 (Suharto 2012). At the international level, the EU's Fuel Quality Directive also requires fuel suppliers to reduce life-cycle GHG emissions by using methane and methane capture technology (EU 2011).

Nevertheless, most companies find it difficult to meet this criterion, as mills are required to carry out costly monitoring of the flow of the wastewater entering the biodigester, the chemical oxygen demand of POME before and after entering the anaerobic digester as well as before entering the aerobic treatment ponds, the quantity of sludge resulting from desludging of the anaerobic digester, the quantity of biogas used by the biogas engine and flare, the methane content of the biogas, and the quantity of diesel fuel combusted for the biogas plant (ZSL 2012). The funding and expertise required for this monitoring make it economically unviable for most companies.

\section{Wood pellet demand}

Biomass is quickly emerging as a major source of renewable energy. Two major economic centers are driving this transition: the EU and East Asia.

The rising demand for biomass in Europe stems from the 2009 Renewable Energy Directive, which mandated that by $202010 \%$ of Europe's energy in transport and heat and power should come from renewable sources (FEM 2012). The response to this regulation was enthusiastic and resulted in a flourishing market for crop-based biofuels. Relatively quickly, however, the excitement gave way to concerns over competition with food production and the potential increases in food prices. Even though the Renewable Energy Directive contains provisions to ensure that biofuel crops are not grown on primary forest or peatland, concerns also emerged about the environmental impact of biofuels in the form of indirect land use change - environmental damage caused by food or other crops being displaced by biofuel plantations.

As a result, in June 2013, the European Commission proposed to reduce the target for renewable energy from first-generation feedstocks from $10 \%$ to $5 \%$ by 2020 (FEM 2013). There is continued disagreement 
in Brussels on this topic. Further discussions on the energy targets for first-generation biofuels are to resume in 2015. Due to methodological uncertainties, the inclusion of indirect land use change into the calculation of emissions from landbased investment has been postponed until 2021. At the same time, the European Commission has strongly endorsed biomass as a carbon-neutral form of bioenergy that has the potential to produce net reductions in GHG emissions in power utilities and other industry sectors.

Preliminary estimates indicate that if biomass is to become a significant contributor to the EU renewable-energy mix, European countries will need to source major supplies (including wood pellets, and energy chips) from overseas (Hewitt 2011; Poyry 2011). By 2020, EU countries may need 100-200 million tonnes of biomass per year to meet the EU renewable energy target. About half of this volume can be generated domestically. The rest is expected to be supplied mainly by Canada, the US and Russia, the three leading wood pellet producers in the world. However, supplies from the US are predicted to shrink considerably in the coming years in the anticipation of meeting the domestic $25 \%$ renewable energy target for 2025. As a result, it is projected that biomass sourcing from Brazil and Central Africa will come to play a major role (Ros et al. 2012).

The other major market for energy biomass is East Asia (Wood Resource Quarterly 2012), which is emerging quickly as a demand locus and is expected to overtake Europe within the next few years (Evans 2013). This transition is currently driven by South Korea and Japan, but China figures to be the difference maker. Both South Korea and Japan are among the top 10 global energy consumers; both are largely reliant on fossil fuels (coal and oil), and both import nearly all of their energy. Although fossil-fuelrelated pollution has been nowhere near as severe in these countries as in China, reducing pollution and GHG emissions has become an important policy objective in South Korea and Japan.

South Korea's foundation for accelerated transition to renewable energy is the 2009 policy to achieve $30 \%$ reduction in GHG emissions by 2020 (MeeYoung 2009). Because more than $90 \%$ of emissions originate in the coal-based industry and power sector, in 2012 the government instituted a compulsory emission reduction quota called the Renewable Portfolio Standard, which will increase 2\% every year until it reaches $10 \%$ in 2020 . This will affect 377 companies in South Korea, of which 13 major power utilities are responsible for most of the emissions.

Missing the emission reduction target would mean a significant financial burden under the cap-andtrade policy which will come into effect in 2015 (Han 2012). As a result, corporations are seeking ways to reduce emissions, and biomass for cofiring coal-based power stations has emerged as the option of choice. South Korea alone is projected to need between 5 and 12 million tonnes of wood pellets per year to meet its 2020 renewable energy target (Lim 2012). Between $75 \%$ and $80 \%$ of this will be imported, mainly from Southeast Asia. The development of these resources is proceeding apace, with major South Korean suppliers securing land and signing pellet delivery deals in the region.

In 2006, Japan formulated ambitious plans to reach a $10 \%$ renewable energy contribution to the national energy mix by 2020. After the 2011 Fukushima nuclear incident, the need to increase use of alternative sources of energy became more urgent. Coal has become a key source of energy for heat and electricity. However, this has raised concerns about import dependency and pollution. As a result, in 2012 the government announced a plan for $20 \%$ of national power generation to come from renewable energy. To achieve this, a feed-in tariff (a form of subsidy) for all power plants using biomass for co-firing technology was put in place for 20 years (Iguchi 2012).

If the 2020 clean-energy target is to be met, Japan will need to import about 13.1 million tonnes of wood pellets (or biomass equivalent) annually, of which it is estimated that the country can generate about 4.6 million tonnes and 8.5 million tonnes will have to be imported (Iguchi 2012). Japan is well positioned to secure the biomass resources it needs. It possesses one of the largest bulk cargo transport fleets in the world, which has been used for wood chip imports for Japan's pulp and paper industry. Increasingly, Japan's pulp and paper producers are embracing pellet-based energy production as an add-on.

China has the potential to be the difference maker in the Asia-Pacific region in terms of demand and supply dynamics for biomass. In 2006, the country put in place an ambitious renewable energy plan calling for $16 \%$ of the national energy mix to come from renewable sources by 2020 . The use of biomass features prominently in this plan in the form of biomass for electric power (30 gigawatts), biomass 
diesel ( 2 million tonnes), and biomass solid fuel (50 million tonnes) (Evans 2013). In theory, China possesses massive biomass resources that could be harnessed to meet its needs (in excess of 300 million tonnes per year). However, because these resources are dispersed and seasonal, and it is illegal to use cultivable land for nonfood biomass, the actual volumes that may be available are a small fraction of the theoretical potential.

Electricity and heat are among the largest drivers of demand for energy resources in China (Evans 2013). Until now, coal has fulfilled most of the need for both. However, concerns over rising air pollution have prompted the national government to put in place a feed-in tariff scheme to encourage co-firing of biomass in coal-based power stations. In order to meet biomass demand for co-firing, China will need 70 million tonnes of biomass annually by 2020 and 110 million tonnes by 2030 .

Wood pellet production is a relatively new enterprise in Indonesia. It has been stimulated by a memorandum of agreement between the Indonesia Ministry of Forestry and the South Korea Forest Service, which stipulates that Indonesia will allocate 200,000 ha of forest land for the establishment of industrial timber plantations and the production of wood pellets in Kalimantan (Naturealert 2009). The memorandum also gives the South Korean government a free 99-year lease for this land. The Korean Forest Service will primarily provide administrative support for this development, and private companies will build and operate the pelletmaking plant (Deparine 2009).

Overall, it is estimated that Indonesia has released about 500,000 ha for timber plantations to support wood pellet production. About half of this is in Papua, 200,000 ha in Sulawesi, and the rest in Java and Kalimantan (Dermawan et al. 2012). Eco-Frontier, a large South Korean supplier of wood pellets and developer of wood pellet mills, seeks to deliver 2 million tons of wood pellets for the Korean market by 2015. About $60 \%$ of this target, or 1.2 million tonnes, is expected to come from five projects in Indonesia. In addition, South Korean companies are teaming up with Indonesian state-owned forestry enterprises that hold several million hectares of underutilized land (Hemawati 2013; Sindonews 2013).

At least three Korean companies have invested in industrial timber plantations for wood pellet production in Indonesia - PT Bio Energy Indoco,
PT Bara Indoco and PT Solar Park Indonesia. Together they have acquired around 200,000 ha in Sulawesi, Sumatra and Java (AgroAsia 2011). The Medco Group has also invested in wood pellets via PT Medcopapua Industri Lestari and PT Selaras Inti Semesta. These two companies have landholdings totaling 300,000 ha in Papua and East and West Nusa Tenggara (Besalicto 2009). South Korea’s LG Group now holds a majority stake in these companies.

\section{Summary}

Indonesia has only been able to successfully develop biodiesel from palm oil since the government initiated investment in biofuels in 2006. It is now the sixth largest producer of biodiesel in the world. Consumption of CPO to produce biodiesel increased from 64,000 metric tonnes in 2006 to 1.76 million metric tonnes in 2012 . This is around $7 \%$ of Indonesia's total estimated CPO production. Around 494,744 ha of Indonesia's oil palm plantations produced CPO in 2011 - roughly $5.5 \%$ of Indonesia's total oil palm area (estimated to be 8.9 million ha in 2011).

Biodiesel is only produced from oil palm because the palm is well established in Indonesia and has the highest oil productivity per unit. Other crops, such as jatropha, have not taken off in Indonesia and have only produced low yields per hectare compared with oil palm.

Despite some growth in biodiesel production, biorefinery utilization remains low. In 2012, biorefineries were operating at only $42 \%$ of their capacity. This is because most companies were continuing to benefit economically from using palm oil to produce cooking oil rather than biofuel. Palm oil is primarily consumed as cooking oil in Indonesia or exported overseas as CPO.

Indonesia did attempt to produce bioethanol from 2006 until 2009; however, bioethanol production ceased in 2010. In Indonesia, bioethanol was primarily produced from molasses, a by-product of sugarcane. Bioethanol production ceased because of increasing production costs due to the increasing price of molasses. It is expected to remain stagnant for some time even if the price of molasses improves, because the area of land planted to sugarcane remains low and Indonesia is already struggling to meet growing domestic demand for sugar in food and beverages. 
Some mills have begun to experiment with biogas methane capture to produce electricity; however, this electricity is not supplied to the electric grid and is only used internally by the mills that produce it. Biogas methane capture is primarily being used to capture gas produced from POME, which is usually left in open-air treatment ponds, where it produces methane, estimated to be 34 times more potent than $\mathrm{CO}_{2}$ over a 100 -year timeframe (IPCC 2013b).

High startup costs as well as demanding criteria for monitoring methane capture have deterred significant investment in biogas methane capture. Companies wishing to export palm-oil-based biofuel will need to invest in this technology, as the EU Fuel Quality Directive requires fuel suppliers to reduce life-cycle GHG emissions by using methane capture technology.

Wood pellet production from wood waste (including sawdust, shavings and wood chips) is a relatively new enterprise in Indonesia. Production is being stimulated by the ambitious plans of the EU, South Korea, Japan and China to reduce dependency on fossil fuels (such as coal and oil) and generate energy from more renewable energy sources. 


\section{Policies that have influenced bioenergy plantation development in Indonesia}

Government policy has primarily focused on encouraging the development of oil palm and other agricultural crops for food and oil production and has relied heavily on fossil fuels for energy. Since 2006 a number of policies have been established to stimulate investment in and development of bioenergy and its feedstocks. Most of these policies have already been noted in comprehensive policy studies on bioenergy undertaken by Caroko et al. (2011) and Dermawan et al. (2012). This section draws upon these studies to identify key policies that have encouraged investment in bioenergy feedstocks and production.

\section{Policies to initiate bioenergy development}

In 2006, the Indonesian government kick-started the biofuel sector and made a firm commitment to encourage the production of biofuel to meet Indonesia’s growing energy needs (Figure 21).

Key biofuel policies established in 2006 included the following:

- Presidential Regulation No. 5/2006, on Indonesia's national energy policy, calls for biofuels to make up $2 \%$ of the energy mix by 2010 and $5 \%$ by 2025, totaling 22.26 billion liters of biodiesel, bioethanol and bio-oil. The overall aim of this policy was to safeguard the national economic interest by improving domestic energy security (Dillon et al. 2008).
- Presidential Instruction No. 1/2006 to 13 central and regional government institutions, on supply and use of biofuels as an alternative energy source, requires relevant government departments to support and promote the establishment of a domestic biofuel industry.

- Presidential Decree No. 10/2006 established a national biofuels task force (Timnas BBN) to coordinate biofuel industry expansion. The task force consists of a steering committee, organizing committee and working groups on various themes, such as policy and regulations, land procurement, cultivation and production, markets, and infrastructure. It is required to (1) design a blueprint for biofuel production to accelerate poverty alleviation and job creation, (2) design a road map for biofuel development, (3) prepare the technical implementation of biofuel and set up an institutional task force, (4) evaluate biofuel development and its potential to alleviate poverty and create jobs and (5) periodically report on biofuel development to the president (Jupesta et al. 2011a).

The initial road map for biofuel development sought to create 3.5 million jobs and to increase income for on-farm and off-farm workers in biofuel sectors up to regional minimum wage levels by 2010. It also sought to develop biofuel plantations on 5.25 million ha of land, create
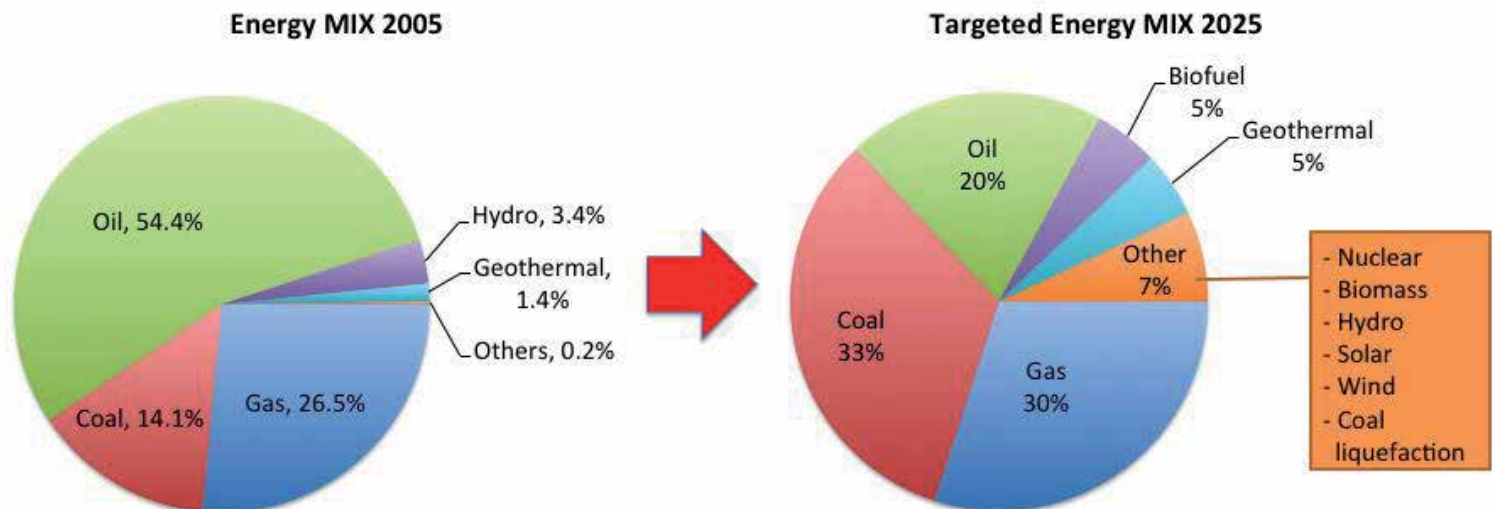

Figure 21. Indonesia's energy mix: 2005 and target for 2025. 
1000 energy-self-sufficient villages, ${ }^{6}$ reduce fossil fuel use by at least $10 \%$ and save USD 10 billion in foreign exchange earnings (Bromokusomo 2007).

\section{Land use allocation policies}

To stimulate and simplify the bureaucratic requirements for investment in biofuel feedstock plantations, the biofuel task force allocated 12 special biofuel zones and targeted four main feedstocks: cassava (mostly in Java, Merauke and South Sumatra), jatropha (mostly in eastern Indonesia and Sulawesi), oil palm (in Sumatra, Kalimantan and Papua) and sugarcane (in Sumatra, Papua and Sulawesi) (Dermawan et al. 2012).

The task force projected that meeting biofuel targets would require about 5.25 million ha of land by 2010 and 10.25 million ha by 2015 . This was to come from degraded or abandoned land, land for which plantation business permits were no longer active, convertible production forest land and forest land that had been legally released for nonforestry purposes (Caroko et al. 2011).

Presidential Instruction No. 1/2006 also mandated governors and district heads to implement biofuel policies at the local level by promoting their use and facilitating the acquisition of land for biofuel feedstocks. This was followed by Ministry of Agriculture Regulation No. 26/Permentan/ Ot.140/2/2007 on guidelines for the establishment of estate crop plantations, which gave governors and district heads the authority to issue plantation business permits for investors within their jurisdictions to meet biofuel needs (Caroko et al. 2011).

Investment in biofuel feedstock plantations was also encouraged in the following regulations:

- Ministry of Agriculture Decree (No. 33/ Permentan/OT.140/7/2006) aims to promote the development of estate crop plantations through expansion, regeneration and rehabilitation. This initiative gave farmers access to credit at preferential rates to develop plantations.

- Law concerning investment (No. 25/2007) allows companies to lease land for plantation development for up to 60 years and to have

6 The Self Sufficient Energy Village Program was not limited to promoting biofuel as a renewable energy source. It also promoted the use of wind, solar, micro-hydro power and biomass (Jupesta et al. 2011b). this extended for another 35 years. Prior to this regulation, companies were only able to obtain rights to cultivate land (hak guna usaha) for 35 years and to have this extended for another 25 years. The regulation also allowed investors to obtain a right to construct and use buildings such as agricultural processing plants ( $h a k$ guna bangunan) for 50 years, with a possible extension of another 30 years. Formerly, this right could be granted for only 30 years with a possible extension of 20 years.

- Ministry of Agriculture Decree No. 26/Permentan/ Ot.140/2/2007 provides guidelines on obtaining estate crop licenses for biofuel feedstocks. It states that a company can obtain a plantation license covering up to 100,000 ha for oil palm, 150,000 ha for sugarcane and 50,000 ha for jatropha, and double those amounts in Papua. This regulation was followed by a Ministry of Forestry decree (No. P22/Menhut-II/2009) that stipulated that up to 100,000 ha of forest land could be converted to plantations, but the clearance permits would only be given in allotments of 20,000 ha. This allocation could be doubled for West Papua and Papua.

- Government Regulation No. 10/2010, concerning the procedure for changing forest status and functions, states that convertible production forests can be converted to accommodate development needs, while ensuring that the remaining forest cover is sufficient. This regulation essentially allows companies to argue a case for converting forest to biofuel plantations. It also allows forest areas designated for conservation, protection or production to be changed if they no longer meet the biophysical conditions of these forest functions. For example, conservation and protection forest can be changed to production forest if it no longer meets the criteria for conservation. Permanent and limited production forests can also be changed to convertible production forests so that oil palm plantations can apply for a forest release permit. In other words, the regulation potentially allows oil palm investors to gain access to land falling within the state-owned forest that was previously off limits.

- Government Regulation No. 60/2012, on procedures for conversion of allocation and functions of forest areas (an amendment to Government Regulation No. 10/2012), and Government Regulation No. 61/2012, on forest utilization (an amendment to Government Regulation No. 24/2010 on forest area 
utilization), stipulate that mining and palm oil businesses that started operations before the enactment of the Law on Spatial Planning and Forest Utilization Permits in 2007 can acquire and own their concessions within forest lands. Articles 51A and 51B of Government Regulation No. 61/2012 offered oil palm plantation and mining companies a six-month window of opportunity (through 6 January 2013) to apply to the Ministry of Forestry for forest land release approvals in convertible production forest and for land lending approvals for concessions within production forest and limited production forest (Jakarta Post 2012).

\section{Incentives for investment in biofuels}

While the above policies help investors to access land for biofuel feedstock plantations, a number of other policies have also been established to provide economic incentives for investment in biofuel feedstocks. These include the following:

- Minister of Finance Decree No. 117/PMK.06/2006 provides subsidized loans to farmers to help them develop biofuel plantations, primarily for oil palm.

- Government Regulation No. 1/2007 stipulates that the biofuels industry is eligible for incentives including income tax reductions, accelerated depreciation and amortization, and a government guarantee against operational losses.

- Minister of Finance Decree (No. 79/PMK.05/2007) enables small and medium-size enterprises to obtain subsidized financing for food and energy crops such as sugarcane, corn, sorghum and cassava. The decree was issued in order to get national banks to support government projects for food security and biofuel feedstocks.

- Presidential Regulation No. 36/2010 encourages foreign investment in biofuel feedstocks by allowing foreign investors to hold $95 \%$ of the shares in oil palm and jatropha plantations. (Investors can only hold up to $49 \%$ of the shares in several other business investments in Indonesia.) This regulation offers foreign investors more security and greater returns on their investments. Foreign investors are still not able to hold $100 \%$ of the shares in a plantation because Law No. 18/2004, on estate crops, stipulates that they must establish joint ventures with Indonesian legal entities, and the Basic Agrarian Law stipulates that they cannot obtain full ownership (hak milik) of Indonesian land. Foreign investors can gain access to land in Indonesia via a right to use or hak pakai provided they have formed a joint venture with an Indonesian company.

Investments in biofuel feedstocks such as oil palm, industrial timber plantations and sugarcane were also strongly encouraged in the government's policy accelerating and expanding the economy, ${ }^{7}$ that aims to make Indonesia one of the 10 biggest economies by 2025 by increasing GDP to USD 4.5 trillion and by increasing GDP per capita from the current USD 3000 to USD 15,000 (Coordinating Ministry for Economic Affairs 2011).

The development master plan encouraged largescale investment in 22 primary activities, including timber, palm oil and agriculture. It lays out a plan to advance Indonesia's economy and is supposedly formulated in consideration of the National Action Plan for Greenhouse Gas (Rencana Aksi Nasional Gas Rumah Kaca) as a national commitment which recognizes global climate change (Coordinating Ministry for Economic Affairs 2011, 23). However, it makes no mention of Reduced Emissions from Avoided Deforestation and Degradation (REDD), renewable energy, biofuels or the government's commitment to reduce GHG emissions by $26 \%$ by 2020. It instead focuses on building up the oil and gas industry and promotes large-scale investment in oil palm, industrial timber and sugar. Oil palm development is to be concentrated in Kalimantan, Sulawesi and Sumatra with investments of around IDR 92 trillion, while sugar will be encouraged in the Merauke Integrated Food and Energy Estate development program, which will be located on 1.2 million ha in Papua (Coordinating Ministry for Economic Affairs 2011, 159). Commercial-scale industrial timber plantation development is primarily encouraged in the Kalimantan economic corridor. The large industrial timber plantation investment is spread across several locations in West Kalimantan (1 million ha with investment of approximately IDR 9.6 trillion), East Kalimantan (417,000 ha, investment of IDR 7.2 trillion), Central Kalimantan (270,000 ha, investment of IDR 5.4 trillion) and South Kalimantan $(89,000$ ha, investment of IDR 1.3 trillion) (Coordinating Ministry for Economic Affairs 2011).

7 Under Presidential Regulation No. 32/2011, President Yudhoyono launched this policy in May 2011; it was supported by sectoral ministries, local governments and state-owned enterprises. 


\section{Trade and commercial policies}

Several policies have also been introduced to regulate the trade and commercial use of biofuels. The most significant include the following:

- Ministry of Energy and Mineral Resources Regulation (No. 051/2006) provides potential investors with guidance on obtaining permission to produce, purchase, sell, export and import biofuels. It requires biodiesel companies to guarantee a continuous supply of biofuel for domestic needs. It also stipulates that permits are valid for up to 20 years and may be extended.

- Minister of Energy and Mineral Resources Regulation No. 32/2008, governing the production, trade and use of biofuels, specifies blending targets for the phased introduction of biofuels up to 2025 for transportation, industry and power generation. Heavy industries and other commercial sectors are required to use at least $5 \%$ biodiesel (in their total fuel consumption) by $2010,10 \%$ by 2015 and $15 \%$ by 2020 . Ethanol targets were set at $7 \%$ by 2010 , $10 \%$ by 2015 and $12 \%$ by 2020 . The regulation also provides fiscal and nonfiscal incentives for those who implement the phased mandatory use of biofuels.

- Presidential Regulation No. 45/2009, concerning the procurement and distribution of biofuels, mandates the Ministry of Energy and Mineral Resources to determine the market price of petroleum and biofuels.

Domestic consumption of biofuels has also been encouraged with government subsidies at similar levels as for fossil fuels. Subsidies to encourage the use of biofuels have been increased from year to year to offset biofuel production costs and rising CPO prices. In 2009, the subsidy was set at IDR 1000 per liter of biofuels. It subsequently increased to IDR 2000 per liter in 2010, IDR 2500 per liter in 2011 and IDR 3000 per liter in 2012. The Ministry of Energy and Mineral Resources and the Parliament agreed to maintain the subsidy for biodiesel in 2013 and increase the subsidy for bioethanol to IDR 3500 in 2013 (Slette and Wiyono 2012; Yulisman 2013).

Domestic supplies of CPO are also controlled in Indonesia by export taxes, which are generally increased as the price of $\mathrm{CPO}$ increases in the global market. This discourages producers from exporting $\mathrm{CPO}$ so that a domestic supply of $\mathrm{CPO}$ can be secured for cooking oil and domestic biofuel production (Casson 1999). From January to
April 1998, the government banned CPO exports altogether as a dramatic increase in the price of CPO to USD 626 per metric tonne in the world market led to a dramatic reduction of domestic stocks (Casson 1999). While the export tax reached a peak of 60\% from July 1998 to February 1999, the government has kept it much lower in recent years and did not tax exports at all in 2008 when the price of CPO fell to USD 433 per metric tonne. However, the recent $\mathrm{CPO}$ price increase has forced the government to gradually increase the export tax, and it was 9\% as of May 2013 (Taylor 2013).

More recently, the government has attempted to reduce dependence on oil and gas imports by making it mandatory for the public to use CPO-based biofuel. To fulfill this policy the Ministry of Energy and Mineral Resources intends to make it mandatory for Pertamina to increase the content of fatty acid methyl ester in diesel fuel for the transportation sector from $2.5 \%$ to $10 \%$ (Priyambodo 2013).

\section{Summary}

The Indonesian government has established a number of policies to stimulate investment in bioenergy feedstocks and production. Government policy regarding biofuels was initiated in 2006 with several key regulations that set targets for biofuel mixes and encouraged district governments to promote the establishment of the domestic biofuel industry. A national biofuels task force was also established to formulate policy and regulations that would stimulate investment in the sector. This task force allocated 12 special biofuel zones and targeted four main feedstocks: cassava (mostly in Java), jatropha (mostly in eastern Indonesia), oil palm (in Sumatra, Kalimantan and Papua) and sugarcane (in Sumatra, Papua and Sulawesi).

Investment in biofuel feedstocks and key agricultural products has been encouraged by allowing investors to acquire land rights with longer tenure periods (up to 60 years, with an extension of 35 years) and to acquire plantation licenses covering up to 100,000 ha for oil palm, 150,000 ha for sugarcane and 50,000 for jatropha; twice as much land can be allocated in Papua. Foreign investors have also been granted the right to acquire $95 \%$ of the shares in a plantation joint venture, and more land has been made available for investors by Government Regulation No. 1/2010, which allows forest areas designated for conservation, protection or production to be changed to limited 
production forests or convertible production forest if the biophysical criteria for these forest functions are no longer fulfilled.

A number of economic and fiscal policies have also been established to stimulate investment in this sector. The government has provided subsidies for farmers wishing to invest in biofuel and other important agricultural crops and has provided access to cheaper credit. The development master plan also encourages investment in oil palm, industrial timber and sugarcane plantations.

Several policies have also been established to secure domestic supplies of CPO, and the government has provided significant subsidies for biofuels sold on the domestic market. An export tax is also used to ensure domestic supply. 


\section{Challenges affecting the growth of bioenergy crops}

Despite policies encouraging investment in bioenergy crops, limited growth is occurring in the sector and Indonesia has failed to meet its targets. This can be attributed to a number of factors including price fluctuations and competition with fossil fuels; competition with food crops; negative press coverage and resulting foreign policy restrictions; complicated land and permit application processes; land tenure issues and a lack of clarity over land ownership; poor infrastructure; limited access to technology and capital; and weak law enforcement.

\section{Price fluctuations and competition with fossil fuels}

In Indonesia, there is a strong belief that the biofuel sector, which depends primarily on palm oil, has been hindered by dramatically rising $\mathrm{CPO}$ prices and falling oil prices (Dillon et al. 2008; Dermawan et al. 2012), which have made palm-oil-based biofuels uncompetitive. The price of $\mathrm{CPO}$ began to increase in late 2006 and reached a high of USD 1096 per metric tonne in June 2008. The price fell in 2008-2009 and then increased again to reach a high of USD 1248 per metric tonne in February 2011 (Figure 22). Price increases caused the government to temporarily reduce the blending target from $5 \%$ to $2.5 \%$ in mid 2007 , and biorefineries were reported to be operating at a fraction of their production capacity.

The high price of CPO has encouraged producers to export rather than produce palm-oil-based biodiesel or even meet domestic demand for cooking oil. The government has attempted to rectify this situation by increasing export taxes, and it increased the export tax for CPO to $25 \%$ in March 2011. This high tax did manage to deter producers from exporting $\mathrm{CPO}$, as the ratio of exports to production declined from $73.7 \%$ in 2010 to $68.8 \%$ in 2011 . The high price of CPO on the international market has discouraged investment in the domestic biofuels industry.

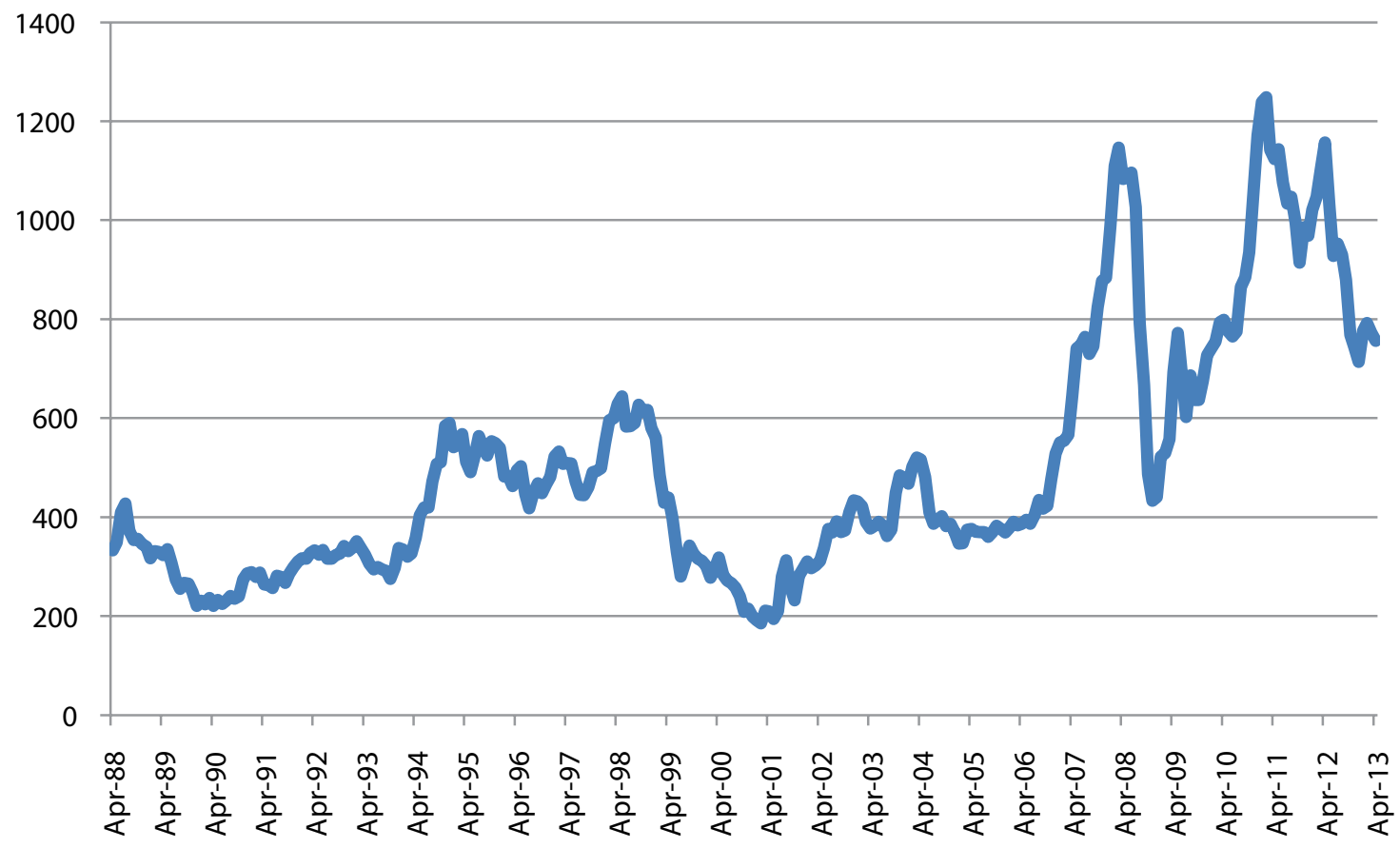

Figure 22. Price of palm oil (USD per metric tonne) in northwest Europe, 1988-2013.

Source: http://www.indexmundi.com/commodities/?commodity=palm-oil\&months=300. 
High palm oil prices have also made palm-oil-based biodiesel production increasingly unprofitable. Pertamina, the state-owned enterprise assigned to purchase biofuel products, has suffered mounting losses from its biofuel blends, as the government required it to sell biofuels at the same price as subsidized petroleum fuels but did not provide additional subsidies to cover the higher cost of biofuels. Dillon et al. (2008) estimated Pertamina's losses due to biofuel blending at IDR 360 billion (USD 40 million) in the period from 2006 to June 2008.

Approximately 60\% of petroleum fuels (gasoline, diesel and kerosene) are subsidized in Indonesia. In 2008, the fuel subsidy cost exceeded IDR 130 trillion (USD 145 billion) (Dillon et al. 2008). The government has consistently failed to increase fuel prices and reduce fuel subsidies. The prices of subsidized gasoline and diesel fuel have held steady at IDR 4500 per liter for the past four years. The Finance Ministry has stated that the appropriate price for fuel is around IDR 6000 (62 US cents) per liter and estimated that a price increase would save the government about IDR 30 trillion (USD 3.08 billion) (Sentana 2013). The Finance Ministry has also estimated that spending on fuel subsidies could reach USD 23 billion in 2013, compared with about USD 20 billion in 2012. Total subsidies for electricity and fuel could end up costing about USD 32 billion, or $20 \%$ of the 2013 budget. The Indonesian government's statistics show that it spends more on fuel subsidies annually than it does on social programs and capital expenditures combined. Fuel is so heavily subsidized that at the end of 2012, the World Bank estimated that Indonesia had the lowest fuel prices of any net oil-consuming nation in the world (Cochrane 2013). The Indonesian government finally increased the price of fuel by $44 \%$ in June 2013 and approved a fuel subsidy of USD 20.2 billion, nearly $4 \%$ of total GDP. The new price for premium fuel is IDR 6500 per liter, up from IDR 4500 per liter. Without the price increase, a subsidy of USD 29.7 billion would have been required. The increased price of fuel may make biodiesel more competitive and able to expand its market share in Indonesia.

The bioethanol market has also been badly affected by prices. It has been argued that the Indonesian Bioethanol Program was effectively ended in 2010 because of a disagreement between the Ministry of Energy and Mineral Resources and fuel ethanol producers over the market price index formulation, which is based on monthly ethanol prices in Thailand (Slette and Wiyono 2012). Fuel ethanol producers in Indonesia have proposed that a domestic fuel ethanol price index would be more realistic since it would include transport costs from producers to blending plants and would better reflect domestic costs of production (Dermawan et al. 2012). The global price of sugar has also fluctuated significantly but has risen overall since 2006. It reached a high of 29.47 US cents per pound in July 2011 (Figure 23). Indonesia heavily relies on sugar imports to meet

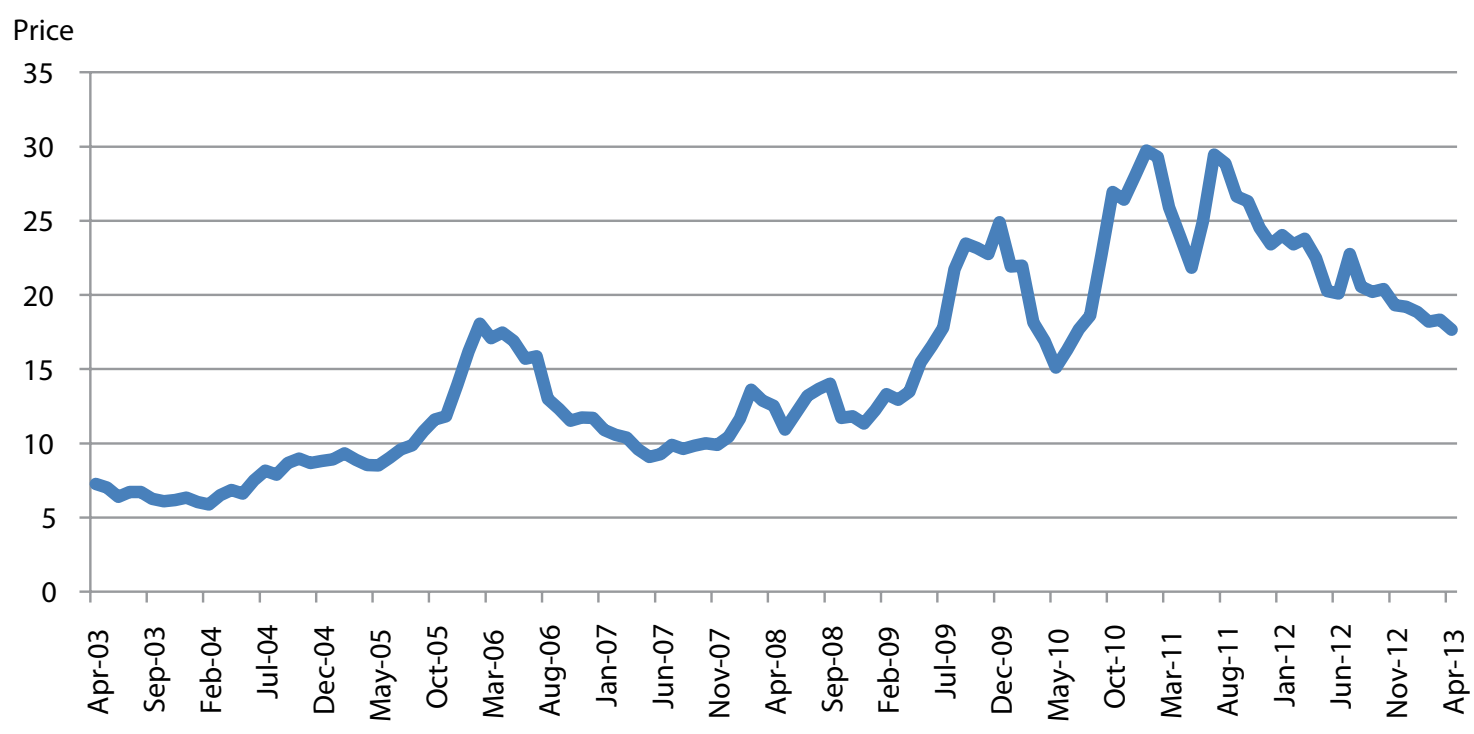

Figure 23. Price of sugar (US cents per pound) on the international market, 2003-2013.

Source: http://www.indexmundi.com/commodities/?commodity=sugar\&months=60. 
domestic demand. Domestic production of sugar therefore had to be directed to food production rather than biofuel.

High feedstock prices and limited government assistance left the biofuel industry floundering. Investors halted plans for new developments, and many existing biodiesel plants suspended their operations. Others reduced their production levels to as low as $10 \%$ of capacity. Even with record-high oil prices in 2008, biofuels were more expensive to produce than petroleum fuels and only added to the government's fuel subsidy burden (Dillon et al. 2008).

\section{Competition with food crops}

The bioenergy sector has also encountered problems because concerns have been raised in the media and by nongovernmental organizations (NGOs) and researchers about the security of food supplies in developing countries where bioenergy feedstocks are being cultivated (Monbiot 2007; Naylor et al. 2007; Runge and Senauer 2008; Matondi et al. 2011). These concerns have been based on the assumption that productive land and/or existing agricultural production may be diverted from food to bioenergy feedstocks and that the price of food would increase so that poor people could no longer afford to purchase it. Of particular concern was the potential pressure on the supplies of palm oil, sugarcane and cassava. Shortages of palm oil have occurred in Indonesia before, and this caused great hardship for poor people (Casson 1999). Sugar deficits are already commonplace, as Indonesia already needs to import sugar to meet domestic consumption needs (Slette and Meylinah 2012). Cassava is the fourth most important food crop in Indonesia and is the primary food source for many of Indonesia's poorest people (Prakesh 2005).

Nevertheless, the relatively slow development of the bioenergy sector in Indonesia is unlikely to have had an impact on domestic food supplies of sugar or CPO, especially since oil palm plantations are continuing to expand at an average annual rate of around 8\% (Bisinfocus 2012). It has been estimated that less than $5 \%$ of total CPO production is being used for biodiesel (Winrock International 2009). Cassava and sugarcane plantation land has not expanded in Indonesia despite interest in the biofuel sector, and these crops are not yet used in Indonesian biofuel production.
Indonesia's food security is primarily constrained by the dwindling area of prime agricultural land in Java and Bali. Each year about 100,000 ha of arable land is lost in Java to nonagricultural uses (commercial, industrial and urban) (USDA 2012a). The main cause of this is population growth and growing demand for a higher standard of living (Doos 2002). This puts immense pressure on rice production, as close to $60 \%$ of Indonesia's rice is produced in Java (USDA 2012a). As a result, Indonesia increasingly relies on imports to meet domestic demands for rice, sugar, soybeans and other foods (Warr 2011). There is also some evidence that rapidly expanding estate crops, particularly oil palm, are replacing food crops and occupying fertile land in outer islands such as Kalimantan (Potter 2011).

Indonesian policy promotes self-sufficiency in food production, and the development master plan encourages the development of new food production centers outside of Java. Integrated, large-scale food estates are the preferred means for stimulating mass food production. One of the largest estates currently under development is the Merauke Integrated Food and Energy Estate, for which 1.2 million ha of land was to be allocated in Papua by 2030 (Obidzinski et al 2013). ${ }^{8}$ The Estate will support the development of rice, corn, soybeans, sorghum, wheat, vegetables, fruits and livestock including chickens, cows, goats and rabbits. Other food estates are planned for East Kalimantan, Sulawesi, Maluku and Sumatra (Coordinating Ministry for Economic Affairs 2011). The Indonesian government has also embarked on a campaign to encourage the use of partial substitutes for rice, which forms a large component of the Indonesian diet, by promoting indigenous staple foods such as corn, cassava and yams (Potter 2011).

\section{Negative press coverage and foreign policy restrictions}

The expansion of bioenergy feedstocks in forest-rich countries such as Indonesia has attracted criticism from NGOs and received attention from foreign and local news organizations (Naylor et al. 2007; WWF 2007; Koh and Wilcove 2008; Knudson 2009). Most criticism focuses on the claim that this trend is contributing to GHG emissions rather than

8 Only around 220,000 ha of land may eventually be released for the Estate, as the original allocation has been reduced to accommodate indigenous land rights and areas that need to be protected for other reasons. 
reducing them. The calculation of exactly how much $\mathrm{CO}_{2}$ is produced in the manufacture of bioenergy is a complex process that needs to consider the following factors:

- land use change in the area where the feedstock is grown

- transportation of the feedstock

- processing of the feedstock into bioenergy

- the efficiency of the feedstock compared with standard fuel.

Studies have also shown that bioenergy feedstock production can result in higher rates of nitrate and phosphate leaching into surface and ground water, pesticide contamination, soil degradation, loss of biodiversity and the deterioration of landscape amenities. Many of these effects are related to the use of fertilizers, pesticides and herbicides (Charles et al. 2013).

The key factor that most analysts are concerned about is land use change in the area where the feedstock is grown. If forest was replaced with oil palm or other feedstocks, it can be assumed that considerable GHG emissions were released into the atmosphere. This is especially the case if a feedstock was planted on peat soils, which are rich in biomass. Issues such as this are widely debated, but there does seem to be consensus that feedstocks for bioenergy are best produced on land that is degraded or had a low biomass content.

Criticism of bioenergy development in forest-rich countries such as Indonesia has caused several countries to develop policies that may restrict imports of bioenergy originating from Indonesia. For instance, the European Commission's revised Renewable Energy Directive (RED 2009/28/EC) sets out sustainability criteria for biofuels and mandates that only biofuels that reduce GHG emissions by $35 \%$ (increasing to 50\% in January 2017 and $60 \%$ in January 2018) compared with petroleum use are acceptable. Biofuels not meeting these criteria cannot be counted toward the share of biofuel (Charles et al. 2013). The European Commission is also considering a proposal to limit the amount of transport fuels from food crops (otherwise known as first-generational biofuels) to no more than $5 \%$ of the total energy used in the transport sector by 2020 . This action was proposed after the use of biofuels became increasingly controversial in the EU and questions emerged about their real contribution to fighting climate change (Torello 2012). There are continued internal arguments and divergent political agendas on this topic, and further discussions on energy targets for first-generation biofuels are set to resume in 2015.

Another standard likely to affect bioenergy produced in Indonesia is the US Environmental Protection Agency's Renewable Fuel Standard, which lays the foundation for achieving significant reductions of GHG emissions from the use of renewable fuels, and the US Clean Air Act, which requires bioenergy producers to meet a minimum $20 \%$ reduction threshold in life-cycle GHG emissions for renewable fuels. For instance, an assessment undertaken by the US Environmental Protection Agency, issued in late 2011 for public comment, determined that biodiesel and renewable diesel produced from palm oil did not meet the minimum 20\% life-cycle GHG reduction threshold needed to qualify as renewable fuel under the Renewable Fuel Standard (EPA 2011). The EPA analysis highlighted a number of key factors that contribute to the life-cycle emissions estimate for palm-oil-based biofuels. For example, palm oil production produces wastewater effluent that eventually decomposes, creating methane, a GHG with a high global warming potential. Another key factor is the expected expansion of oil palm plantations on land with carbon-rich peat soils, which leads to significant releases of GHGs to the atmosphere (EPA 2011).

These policies are gradually closing the door to Indonesian exports of biofuel, as Indonesia has not yet been able to convince buyers that biofuel crops are not replacing carbon-rich landscapes. Indonesian biofuels are at the mercy of other governments' subsidy and market-access policies, as biofuels for domestic use are not currently viable without some form of government support.

\section{Complicated land application and permit processes}

While the government has released several regulations that aim to speed up plantation development in Indonesia, the process of acquiring land for plantations involves a number of bureaucratic hurdles and can take considerable time. Several permits need to be acquired before an investor can begin to plant bioenergy feedstock crops. In the case of oil palm, investors must first secure a location permit (izin lokasi) and a plantation business license (izin usaha 
perkebunan) from the district head, or from the provincial head if the area lies across two districts (Plantation Law 18/2004; Ministry of Agriculture Regulation 26/2007). The area slated for a location permit should be reflected in local spatial plans as suitable for plantation development (WCS 2010). A principal piece of supporting evidence that must be submitted with the plantation business license application is an environmental impact assessment (EIA) (analisis mengenai dampak lingkungan) (Environment Protection Law 32/2009). Companies can then proceed to acquire a timber utilization permit (ijin pemanfaatan kayu) from the district head or governor if the concession area is outside the state-owned forest, or a permit allowing the release of forest land from the state-owned forest (pelepasan kawasan) from the Ministry of Forestry, if the area slated for development lies within the state-owned forest. If the Ministry of Forestry does issue a permit for forest clearing, a decree will also be issued to release that land from the state-owned forest. The final major step in establishing a plantation is to secure land title by obtaining a hak guna usaha (HGU) or land use right. This license can be given to an Indonesian citizen or legal entity for 60 years and extended for another 35 years. The plantation law (18/2004) stipulates that the HGU can be revoked if the holder abandons the site for three years or fails to clear or develop a minimum area within a given period. The HGU application must be submitted to the Provincial Land Office (Badan Pertanahan Nasional-Propinsi) along with a range of supporting documents such as the entity's tax identification number, maps approved by the head of the local Land Office, company deeds, a copy of the location permit (izin lokasi) and any relevant timber use permit.

Bioenergy feedstock developments also need to comply with development plans (governed by Law No. 25/2004) and spatial plans outlining land use (governed by Law No. 26/2007). Spatial planning is an extremely political process in Indonesia, and it can take years for consensus over spatial plans to be reached. Land insecurity is prevalent when spatial plans are delayed and actors with competing interests cannot reach agreement on land allocations (Caroko et al. 2011).

Securing land for plantation developments has also been complicated by Indonesia's decentralization process, which has sought to grant provincial and district governments greater authority to manage responsibilities previously under the control of the central government. ${ }^{9}$ While decentralization was intended to increase efficiency, improve public service and empower local stakeholders, it has often discouraged investors because there has been an abundance of conflicting and overlapping licenses issued by local and central authorities. The licensing process has also become more costly, time consuming and inefficient because investors now have to acquire permits from more actors at the district and provincial levels (Casson et al. 2007a). Governors and district governments can now issue location permits and licenses for agriculture and bioenergy developments if they do not lie within the state owned forest; but if they do, the central government still has the authority to decide whether forest lands may be converted. Investors must first secure approvals from provincial or district governments and then submit applications for forest conversion to the Ministry of Forestry (Caroko et al. 2011). It can be argued that these complicated permit systems have been established to protect Indonesia's forests; however, permit issuing has long been associated with corruption, cronyism and bribes, and extended permit application processes tend to provide more opportunities for rent seeking.

\section{Land tenure issues and lack of clarity over land ownership}

Even if investors can navigate the complicated land application process and legally secure land for bioenergy feedstock development, they may still encounter problems on the ground because laws put in place to ensure that communities are consulted in large-scale plantation developments are not enforced or adhered to. ${ }^{10}$ This often results in considerable conflict when a company begins to clear land and establish a plantation.

9 Law 22/1999 was replaced by Law 32/2004 on Regional Autonomy, and Law 25/1999 was replaced by Law 33/2004 on the Fiscal Balance between the Central Government and the Regions. A special autonomy law for Papua was issued in 2001 (Law 21/2001).

10 Ministry of Agriculture/National Land Agency Decree $21 / 1994$ concerns procedures for the acquisition of land by companies in connection with investment, and Ministry of Agriculture/National Land Agency Regulation 2/1999, concerning location permits, sets out four steps for consulting local communities. But these regulations are weakly enforced. 
The rights of customary people are recognized in Article 18 of Indonesia's Constitution and the Basic Agrarian Law (No. 5/1960); however, these rights have been subsidiary to national development objectives and interests until recently. The state was effectively granted the right to control land, water and other natural resources and to determine how these resources would be used and allocated. Consequently, large-scale development projects that had the ability to generate employment, revenue and other economic benefits have been prioritized and considered to be of more importance to the national economy than customary peoples' rights to land resources. A top-down approach to designing and determining large-scale land use projects still characterizes decision-making processes.

The Basic Forest Law (No. 41/1999) also recognizes customary forests; however, these forests were considered to be state forests until May 2013. Customary communities only had the right to manage and use these forests if they could provide strong evidence of a historical link to the land and their existence is recognized by the state. Customary communities could not own forest land located within the state-owned forest because that land falls under the jurisdiction of the Ministry of Forestry. Customary lands within the stateowned forest could often be allocated to logging or industrial timber plantation companies by the Ministry of Forestry.

This situation may improve for customary communities, as Indonesia's Constitutional Court ruled in May 2013 that indigenous peoples' customary forests should not be classed as state forest areas. This decision was taken after Indonesia's national indigenous peoples' organization, Aliansi Masyarakat Adat Nusantara (Indigenous Peoples Alliance of the Archipelago), filed a petition about this issue in March 2012 (Lang 2013b). This landmark ruling still needs to be clarified further, but it potentially poses a threat to plantation companies that have been allocated customary forests. This situation is complicated by the fact that limited information exists on the location of customary forests and other community-based forest areas. Plantations and other concessions allocated for economic development initiatives, such as mining and logging, often overlap with customary lands and displace local people. This situation has often resulted in widespread conflict and hinders plantation targets and other developments.
The lack of secure tenure for local populations is recognized as a principal driver of deforestation in many developing countries (Angelsen 2008). Consequently, the land rights of local people are key issues addressed by the RSPO Principles and Criteria and the Roundtable on Sustainable Biomaterials (RSB). Principle 2 of the RSPO standard requires companies to ensure that the right to use the land is demonstrated and is not legitimately contested by local people who can demonstrate that they have legal, customary or use rights, and to ensure that their use of the land does not diminish the legal, customary or use rights of other users without their free, prior and informed consent. The RSB's Principle 12 also requires biofuel operations to respect both informal and formal land rights and to ensure that the free, prior and informed consent of communities has been acquired and used to negotiate compensation, acquisition or voluntary relinquishment of rights by land users or owners. Regrettably, these principles are rarely adhered to in reality. Only 6\% (99) of the 1613 known oil palm companies were members of the RSPO in 2012 , and only 37 companies had been certified (Bisinfocus 2012; Appendix 10).

\section{Poor infrastructure}

The Indonesian bioenergy sector is also challenged by poor infrastructure such as roads, bridges, ports, and communication and electricity connections. This is particularly important for the oil palm industry, as fresh oil palm fruit has to be processed within 48 hours (Casson 1999).

Poor infrastructure is a key focus of the development master plan (Coordinating Ministry for Economic Affairs 2011, 30), in which the government pledges to support the acceleration and expansion of Indonesian economic development by

- creating an integrated system of national logistics, national transportation, and regional development, communication and information systems

- identifying transportation hubs and distribution centers to facilitate the logistical needs for primary and supporting commodities

- strengthening connectivity of intra- and intercorridors as well as global connectivity

- improving information and communication technology networks to facilitate all economic, government and education-sector activities. 
Implementing these polices will be difficult, costly and time consuming, and investment in the sector is likely to be deterred until significant improvements are made.

\section{Limited access to technology and capital}

Before 1996, when the Indonesian government launched its biofuel policy, minimal research was conducted on biofuel. E10 (a mixture of 90\% gasoline and $10 \%$ ethanol) was tested on 100 cars and 32 motorcycles in Indonesia during the 1980 s, but no further work was undertaken over the following decade, as oil remained abundant and cheap (Dillon et al. 2008).

However, when it was realized that petroleum supplies were dwindling, new research began on alternatives to fossil fuels. Government, university and industry research institutions, including the Oil and Gas Institute, Lemigas and Pertamina, began to undertake research on and development of biodiesel (Dillon et al. 2008). Following several trials, a mixture of biodiesel and petroleum diesel was determined to be safe for use in ordinary diesel engines. By 2001, the Ministry for Research and Technology had built a laboratory-scale factory capable of producing 1.5 tonnes of biodiesel a day (620,000 liters per year). This facility is used mainly for research and development rather than actual production of biodiesel (Dillon et al. 2008).

Biofuel production is a relatively new enterprise in Indonesia, and only large, well-financed companies have been able to provide the necessary capital, expertise and technology. Technological developments are currently driven by the needs to ensure cost competitiveness, to have access to a wider array of feedstocks and to increase the GHG reduction potential of biofuels. Research on secondgeneration biofuels (ligno-cellulosic ethanol, biomass to liquid) is also growing. These developments require large investments.

Several Indonesian research institutions have done pioneering work on biodiesel development, including Lemigas (Oil and Gas Technology), PPKS Medan (Oil Palm Research Institute based in Medan), the Bandung Institute of Technology and the Agency for the Assessment and Application of Technology. The Bandung Institute of Technology focuses on conversion technology, and the Ministry of Agriculture, through the Center for Studies in Mechanization in Agriculture, focuses on mixing biodiesel and automotive diesel fuel for stationary machinery (Wirawan and Tambunan 2006). Indonesian biodiesel development focuses mainly on production process technology, engineering, biodiesel property and performance tests, standardization and promotion (Jupesta et al. 2011a).

To accelerate information exchange among biodiesel stakeholders and to promote biodiesel development, Forum Biodiesel Indonesia was founded in 2002. Members of this national forum include scientists from universities and research institutes, automotive industry associations, a palm oil association, engineering industries, biodiesel producers, relevant government offices (such as the Ministry of Transportation, Ministry of Energy and Mineral Resources and Ministry of Agriculture) and several NGOs. The Forum has conducted research on optimal blending of biodiesel with gasoline, developing technology for jatropha oil extraction and its conversion to methyl ester, and technology and engineering of biodiesel production. Nevertheless, considerable investment in technology, expertise and machinery is still required to make the Indonesian biofuel sector economically viable (Jupesta et al. 2011a).

\section{Weak law enforcement}

Weak legal protections for local communities and lax enforcement of environmental regulations threaten to undermine the green credentials of Indonesia's bioenergy feedstock plantations and other agricultural crops.

Enforcement and monitoring of large-scale agricultural crops, including bioenergy feedstocks, is challenging for the Indonesian government. Development frequently occurs in the outer reaches of the archipelago, where the official presence is limited and mapping is poor. Serious breaches of Indonesian law - including operating without a concession title, illegal clearing of forests, planting in national parks and intentional burning - have been reported by NGOs on a regular basis (EIA and Telapak 1999; Antara 2005; Wakker 2005; Greenpeace 2007; Nellemann et al. 2007; EIA and Telapak 2012; Obidzinski et al. 2012). Weak enforcement of regulations designed to protect local communities and the environment (such as the Environmental Impact Assessment Law No. 23/1997) is also reported as commonplace (Caroko et al. 2011; EIA and Telapak 2012). These reports 
have tarnished the reputation of bioenergy feedstock developments (particularly oil palm) in Indonesia and made it more difficult for palm-oil-based biodiesel producers to export biodiesel to restricted markets such as the US and the EU.

\section{Summary}

The Indonesian bioenergy sector is currently underperforming, with production well below projected targets. The primary factor that has derailed the sector is the rising price of bioenergy feedstocks (CPO and molasses). The price of CPO began to rise in 2006, shortly after the Indonesian government released its key policies on biofuel, and it has been relatively high ever since. Price increases caused the government to reduce its blending targets and encouraged producers to export $\mathrm{CPO}$ rather than produce biodiesel. High CPO prices have also caused problems for Pertamina, the state-owned company assigned to purchase and distribute biofuel on the domestic market. Significant losses have resulted from government subsidies and blending targets.

The price of sugar has fluctuated significantly but has risen overall since 2006. It reached a high of 29.47 US cents per pound in July 2011. This has caused problems because Indonesia relies heavily on sugar imports to meet domestic demand. Domestic production of sugar therefore has had to be directed to food production rather than biofuel.

The bioenergy sector has also been plagued by concerns about food security and the impact of expanding oil palm plantations on forests and peatlands. These concerns have deterred some investors from investing in biofuel production and caused several countries to restrict imports of biofuel from Indonesia. For instance, the EU and the US have both restricted biofuel imports from Indonesia unless producers can demonstrate that their biofuel has resulted in a $35 \%$ (for the EU) or 20\% (for the US) reduction of GHG emissions.

Bioenergy producers and investors have also been burdened by a number of domestic factors that make it difficult to purchase or rent land for agricultural developments - complicated application and permit processes and land tenure issues. While the government has attempted to provide legislation that supports bioenergy feedstock development in recent years, complicated and bureaucratic application processes prolong plantation development processes and make them costly and complicated. Insufficient provisions for seeking the consent of local and customary communities for the release of land and the absence of spatial data on customary or local land has resulted in considerable conflict on the ground when plantations begin to plant bioenergy feedstocks. These conflicts slow development and add further unexpected costs. Nevertheless, corrupt practices still allow plantation companies to fasttrack bureaucratic hurdles and sidetrack community consent procedures.

Poor infrastructure and insufficient access to technology is also slowing biofuel development. Finally, lax enforcement of social and environmental regulations is tarnishing the image of the industry and making it more difficult for it to meet guidelines being implemented in importing countries such as the US and EU. 


\section{Deforestation and the socioeconomic causes of land use change in Indonesia}

Indonesia has had one of the highest rates of deforestation in the world for the past 30 years (Hansen et al. 2008, 2009). Deforestation and land use change became a concern in the early 1970s, when large-scale commercial logging concessions were established for the first time. Although logging concessions were intended to establish a system of long-term timber production, they often led to serious forest degradation followed by clearance and conversion to other forms of land use.

Estimates of deforestation vary as analysis has been carried out in different ways, over different time periods and with different sensors. A mapping exercise undertaken for the government's transmigration program (RePPProT 1990) estimated that Indonesia lost $27 \%$ of its forested area between 1950 and 1985. Sunderlin and Resosudarmo (1996) estimated that the annual deforestation rate was 0.6-1.2 million ha per year between the 1970s and 1990s. A forest cover mapping effort carried out in 1999 by the Indonesian government with support from the World Bank concluded that the average annual deforestation rate for 1985-1997 was around 1.7 million ha. Hardest hit during this period were Sulawesi, Sumatra and Kalimantan, all of which lost more than $20 \%$ of their forest cover (Holmes 2000). Forest Watch Indonesia and Global Forest Watch (FWI/GFW 2002) speculated that Indonesia lost more than 20 million ha of forest cover between 1985 and 1997 - about $17 \%$ of the forest area existing in 1985.

Over the past decade, technology for estimating deforestation rates has improved; however, estimates have been carried out in different ways and have produced different results. Harris et al. (2012) estimated that 701,000 ha of forest were lost per year in Indonesia between 2000 and 2005, resulting in carbon emissions of $105 \mathrm{Tg}$ a year. Researchers at the Center for Remote Imaging, Sensing and Processing at the National University of Singapore estimated that Indonesia lost more than 8.8 million ha of forest between 2000 and 2010. During this time, Sumatra lost $23.7 \%$ of its forest cover or 3.5 million ha and Borneo (including Brunei and Sarawak) lost 5 million ha, accounting for $12 \%$ of its 2000 cover. Java was the only island to see forest recovery, with a net increase of 37,000 ha or $4 \%$ of its 2000 cover. Forest loss was most stark in lowland forests and peatlands. Sumatra lost more than $41 \%$ of its peatlands during the period, while Borneo lost a quarter (Miettinen et al. 2011).

Margono et al. (2012) estimated that Sumatra had lost $70 \%$ of its forest cover by 2010 . Between 1990 and $2010,47 \%$ (7.54 million ha) of Sumatra's primary forest cover was lost and an additional 2.31 million ha was degraded. The rate of primary forest cover change (loss and degradation) slowed from 7.34 million ha in 1990-2000 to 2.51 million ha in 2000-2010. An average of 0.73 million ha was lost per year in 1990-2000 and 0.25 million per year in 2000-2010. Most primary forest loss occurred in the provinces of Riau and Jambi, where oil palm and timber plantations are now dominant (Margono et al. 2012).

Broich et al. (2011), based on mapping at moderate spatial resolution, estimated that forest cover loss for Sumatra and Kalimantan for 2000-2008 was 5.39 million ha, $5.3 \%$ of the land area, and $9.2 \%$ of the year 2000 forest cover. Their analysis revealed that $46 \%$ of the deforestation had occurred within the provinces of Central Kalimantan and Riau, where most oil palm and industrial timber plantations have been established. This reveals a direct link between oil palm and industrial timber plantation development and forest loss in these two provinces.

Analysis conducted by the World Agroforestry Research Center estimated that 22.64 million ha of forest was lost between 1990 and 2000 and another 6.42 million ha between 2000 and 2005 (Ekadinata et al. 2011). Forest cover in Indonesia decreased from 128.72 million ha in 1990 to 99.6 million ha in 2005. Annual forest loss decreased from 2.26 million ha per year during 1990-2000 to 1.28 million ha per year during 2000-2005. The study revealed that most deforested areas became shrub land in the earlier period and estate or crop land in the later period. Unsustainable logging and forest fires were the main causes of deforestation for the earlier period, while meeting demands for agricultural produce and export commodities were primary causes of the later deforestation (Ekadinata et al. 2011). 
Statistics from the Food and Agriculture Organization (FAO 2010) indicate that Indonesia lost 1.9 million ha of forest a year between 1990 and 2000. These rates slowed to 498,000 ha per year between 2000 and 2010. Between 1990 and 2000, Indonesia recorded the second largest annual net loss of forest (behind Brazil, which lost 2.89 million ha of forest per year). During 2000-2010, Indonesia recorded the third largest annual net loss of forest per year, after Brazil (2.64 million ha) and Australia (562,000 ha). Over the period 2000-2010, Indonesia reported a significant reduction in the average annual area of primary forest lost. The period 2005-2010 showed a significant decline in deforestation compared with 2000-2005 (FAO 2010).

Statistical data from the Ministry of Forestry indicate that around 23 million ha of forest (approximately 850,000 ha per year) was lost between 1982 and 2009, most of it in conversion forest and limited production forest (Table 17).

Recent high-resolution analysis of forest cover change (Hansen et al. 2013) revealed a different picture, indicating that Indonesia has lost around 1 million ha of forest per year. This analysis indicated that deforestation rates have fluctuated significantly over 2000-2012, as less than 100,000 ha per year was lost between 2000 and 2003, while an estimated 2 million ha was lost between 2011 and 2012. A similar rate of deforestation was detected for 2008-2009.

Most analysis has found that deforestation rates have been slowing in Indonesia, likely because accessible and economically valuable timber has become scarce. Consequently, the Ministry of Forestry has been quoted as stating that Indonesia's deforestation rate fell from 830,000 ha per year during 2006-2009 to
450,000 ha per year during 2009-2011 (Mongabay 2012b). These estimates are considered too low by other analysts (Table 18).

All of these estimates can only be regarded as approximations. The forest cover data suffer from a number of uncertainties. Most analysis is based entirely on satellite imagery that was not verified by field checks. Natural forest is often misinterpreted as timber or estate crop plantations, and heavy cloud cover makes accurate estimates difficult (Hansen et al. 2009; Margono et al. 2012). Unlike Brazil, Indonesia does not have a seasonally cloud-free window, and overcoming persistent cloud cover requires more data-intensive methods (Broich et al. 2011). In Sumatra, Kalimantan, and Sulawesi, 'no data' cloud areas covered a total of 5.3 million ha, or $18 \%$ of the measured forest area in the World Bank's analysis of deforestation (Holmes 2002).

Cloud cover is difficult for high-spatial-resolution sensors to penetrate. Since these satellites typically only revisit the same area once every 1-2 weeks, cloud-free images are less frequently recorded in Indonesia (Margono et al. 2012). Landsat is the only sensor that can provide a high-resolution historical record of land use change. An alternative method is to draw on moderate-spatial-resolution sensors, such as MODIS, that pass over the same spot every one or two days. This considerably increases the likelihood of obtaining cloud-free observations, but at a coarser spatial resolution of 250 meters instead of the 30 -meter spatial resolution available via Landsat. This essentially means that some forest cover loss will not be recorded. This method is also problematic because most forest cover loss is quickly followed by forest cover gain in the form of timber plantations and palm estates (Hansen et al. 2008).

Table 17. Forest cover loss according to MoF data in 1982 and 2009.

\begin{tabular}{llll}
\hline $\begin{array}{l}\text { Forest classification by } \\
\text { function }\end{array}$ & \multicolumn{2}{l}{ Forest cover (millions of ha) } & $\begin{array}{l}\text { Forest cover loss } \\
\text { (millions of ha) } \\
1982-2009\end{array}$ \\
\cline { 2 - 4 } & 1982 & 2009 & 0.4 gain \\
\hline Conservation forest & 14.8 & 15.2 & 3 \\
Protection forest & 26.0 & 23.0 & 5.8 \\
Limited production forest & 24.6 & 18.8 & 2.8 \\
Production forest & 24.9 & 22.1 & 11.8 \\
Conversion forest & 22.8 & 11.0 & 23 \\
\hline Total & 113.1 & 90.1 & \\
\hline
\end{tabular}

Sources: MoF and FAO (1990) and MOF (2009) in Brockhaus et al. (2012). 
Table 18. Deforestation estimates.

\begin{tabular}{|c|c|c|c|}
\hline $\begin{array}{l}\text { Organization producing } \\
\text { estimate }\end{array}$ & Sensor used & Time frame & Deforestation estimate \\
\hline $\begin{array}{l}\text { RePPProT (transmigration } \\
\text { program) }\end{array}$ & Landsat & 1950-1985 & $27 \%$ of Indonesia's forested area \\
\hline $\begin{array}{l}\text { Sunderlin and Resosudarmo } \\
1996\end{array}$ & Landsat & 1970-1990 & 0.6-1.2 million ha per year \\
\hline World Bank (Holmes 2000) & Landsat & 1985-1997 & $\begin{array}{l}1.7 \text { million ha per year, or } 20 \% \text { of existing } \\
\text { forest cover, with most deforestation } \\
\text { occurring in Sumatra, Kalimantan and } \\
\text { Sulawesi }\end{array}$ \\
\hline World Resources Institute & Landsat & 1985-1997 & $\begin{array}{l}20 \text { million ha ( } 1.6 \text { million ha per year) }-17 \% \\
\text { of the forest area existing in } 1985\end{array}$ \\
\hline FAO 2010 & Landsat & $1990-2000$ & 1.9 million ha per year \\
\hline Harris et al. 2012 & & $2000-2005$ & 701,000 ha per year \\
\hline $\begin{array}{l}\text { Center for Remote Imaging, } \\
\text { Sensing and Processing, } \\
\text { National University of Singapore } \\
\text { (Miettinen et al. 2011) }\end{array}$ & Landsat & $2000-2010$ & $\begin{array}{l}8.8 \text { million ha ( } 0.88 \text { million ha per year), with } \\
\text { most deforestation occurring in Sumatra ( } 3.5 \\
\text { million ha) and Borneo ( } 5 \text { million ha) }\end{array}$ \\
\hline Margono et al. $2012^{\mathrm{a}}$ & $\begin{array}{l}\text { Landsat and } \\
\text { MODIS }\end{array}$ & 1990-2010 & $\begin{array}{l}7.34 \text { million ha ( } 0.73 \text { million ha per year) in } \\
1990-2000 ; 2.51 \text { million ha ( } 0.25 \text { million ha per } \\
\text { year) in 2000-2010, with most deforestation } \\
\text { occurring in Riau and Jambi (Sumatra) }\end{array}$ \\
\hline Broich et al. $2011^{\mathrm{b}}$ & $\begin{array}{l}\text { Landsat and } \\
\text { MODIS }\end{array}$ & $2000-2008$ & $\begin{array}{l}5.39 \text { million ha ( } 0.67 \text { million ha per year), with } \\
\text { most deforestation occurring in Riau and } \\
\text { Central Kalimantan }\end{array}$ \\
\hline $\begin{array}{l}\text { World Agroforestry Center } \\
\text { (Ekadinata et al. 2011) }\end{array}$ & Landsat & 1990-2005 & $\begin{array}{l}22.64 \text { million ha (average of } 2.26 \text { million ha per } \\
\text { year) in 1990-2000; } 6.42 \text { million ha (average of } \\
1.28 \text { million ha per year) in } 2000-2005\end{array}$ \\
\hline Ministry of Forestry & Landsat & 1982-2009 & $\begin{array}{l}23 \text { million ha ( } 0.85 \text { million ha per year), with } \\
\text { most deforestation occurring in conversion } \\
\text { forest and limited-production forest }\end{array}$ \\
\hline FAO 2010 & Landsat & $2000-2010$ & 0.56 million ha per year \\
\hline $\begin{array}{l}\text { Ministry of Forestry (Mongabay } \\
\text { 2012b) }\end{array}$ & Landsat & 2006-2011 & $\begin{array}{l}0.83 \text { million ha per year in 2006-2009; } 0.45 \\
\text { million ha per year in } 2009-2011\end{array}$ \\
\hline Hansen et al. 2013 & Landsat & $2000-2012$ & $\begin{array}{l}\text { An average of } 1 \text { million ha per year; } \\
\text { fluctuating rates - less than } 0.1 \text { million ha for } \\
2000-2003 \text {, over } 2 \text { million ha in } 2011-2012 \\
\text { and just under } 2 \text { million ha in } 2009 / 10 \text {, with } \\
\text { most deforestation occurring in Riau and } \\
\text { Central Kalimantan }\end{array}$ \\
\hline
\end{tabular}

Note: Estimates focused on Indonesia as a whole, with these exceptions: a Sumatra; b Sumatra and Kalimantan.

Because of these challenges, continuous land cover change analysis undertaken on an annual basis for a period of 10-20 years is not yet available for all of Indonesia. Analysis of this kind is being carried out under the auspices of the Indonesian National Carbon Accounting System; however, it may only cover 2000-2010. The combination of rapid recovery of forest canopies and paucity of viable cloud-free observations poses a unique monitoring challenge for Indonesia (Margono et al. 2012). Considerable funding and effort are required to improve this situation.

The following sections go into more detail about the demographic, political and economic factors that have driven deforestation in Indonesia. 


\section{Demographic drivers of deforestation}

Population grew steadily in Java at around 2\% per year throughout the 19th century, thus doubling itself roughly every 35 years (White 1983). This trend continued in the 20th century (Table 19). Population growth has resulted from declining mortality rates and improved standards of living (Geertz 1963).

Over the past 40 years, population growth has been significant. Java's population almost doubled, from 76 million people in 1971 to around 136.6 million in 2010. Population has more than doubled in Sumatra, from 20.8 million people in 1971 to 59.6 million in 2010. A similar situation can be found in Kalimantan, where the population increased from 5.1 million in 1971 to 13.7 million in 2010 , and in Sulawesi, where the population increased from 8.5 million in 1971 to 17.3 million in 2010. Population has almost quadrupled in Papua, from 1.1 million in 1971 to around 3.6 million in 2010 (BPS 2012).

In Java, it has been argued that population growth and colonial expansion gave rise to "agricultural involution" - the adaptation of peasant society to a colonial system designed to extract land, labor, produce and money (taxes) from village economies (Geertz 1963). The adaptation allowed more rice to be produced in rice terraces while plantation crops such as sugar were expanded and exploited. These crops absorbed Java's growing population at the expense of its forests. Eventually, this agricultural revolution outgrew itself and the Indonesian government embarked upon a policy of transmigration whereby people from the highly populated islands of Java and Bali were relocated to less populated islands such as Sumatra, Kalimantan and Papua (McAndrews 1978).

The Dutch colonial government initiated a smallscale transmigration program in 1905 to move excess population from Java to the outer islands, primarily Sumatra (McAndrews 1978). This program continued and eventually gave rise to a large-scale national transmigration program in 1950 , which sought to move thousands of families from Java and Bali to the less populated outer islands (Sumatra, Kalimantan, Sulawesi and Papua) (Hardjono 1977; McAndrews 1978). Between 1932 and 1974, around 1 million people were moved to the outer islands, and the 1971 census showed that 1.96 million Javanese-born people were permanently resident in the outer islands, with a total outmigration from Java, including returned migrants to Java, of 2.37 million. The national transmigration program ran at its peak in the 1970 s, with as many as 72,018 people moving in 1973 (McAndrews 1978). The national plan for 1979-1984 aimed to move 500,000 people a year (Adhiati and Bobsien 2001).

The rise of Indonesia's large-scale transmigration program coincided with an increasing emphasis on the development and exploitation of the outer islands (McAndrews 1978). In the early colonial days, transmigration was principally seen as a means to decrease population pressure on the overcrowded island of Java. However, in the mid-1960s, it was no longer seen solely as an answer to Java's overpopulation but as a means for redistributing human resources for the development of the outer islands (McAndrews 1978). Indeed, the policy has had little impact on the population of Java, but it was able to redistribute people to less populated areas.

This process has contributed to accelerated deforestation in the outer islands. Many transmigration programs were poorly managed and funded, and this led to a range of social and ecological problems. Transmigrants were often moved to poor sites in terms of location, accessibility and soil conditions. ${ }^{11}$ This led to slow project development, abandonment, costly rehabilitation and serious ecological damage (McAndrews 1978). One of Indonesia's worst environmental disasters occurred in the "mega-peat area" in Central Kalimantan. A 1 million ha project was launched in 1995 to guarantee rice self-sufficiency; however, the scheme quickly turned into an environmental catastrophe as peat forests were stripped, burned, drained and rendered unusable. Between January 1996 and July 1998, more than $4000 \mathrm{~km}$ of irrigation channels were laid out in pristine swamp forest. Because the topography and hydrology of the area was not considered, the peatland was severely drained by the poorly designed, constructed and maintained channels. This made it even more difficult to grow agricultural crops on acidic peat soils, which are not ideally suited

11 This often occurred because the government lacked good data on soil, forest cover, topography and other ecological features. To improve this situation, a team from the Land Resources Department of the UK Overseas Development Administration produced a series of maps at a scale of $1: 250,000$, accompanied by descriptive reports for each of the provinces, beginning with Central Kalimantan in 1985 and followed by South and East Kalimantan in 1987 and West Kalimantan in 1987. The maps were not ground checked but were based on available maps, aerial photographs, radar and satellite imagery, together with supporting data on soils, geology and other features (Potter 1991). 


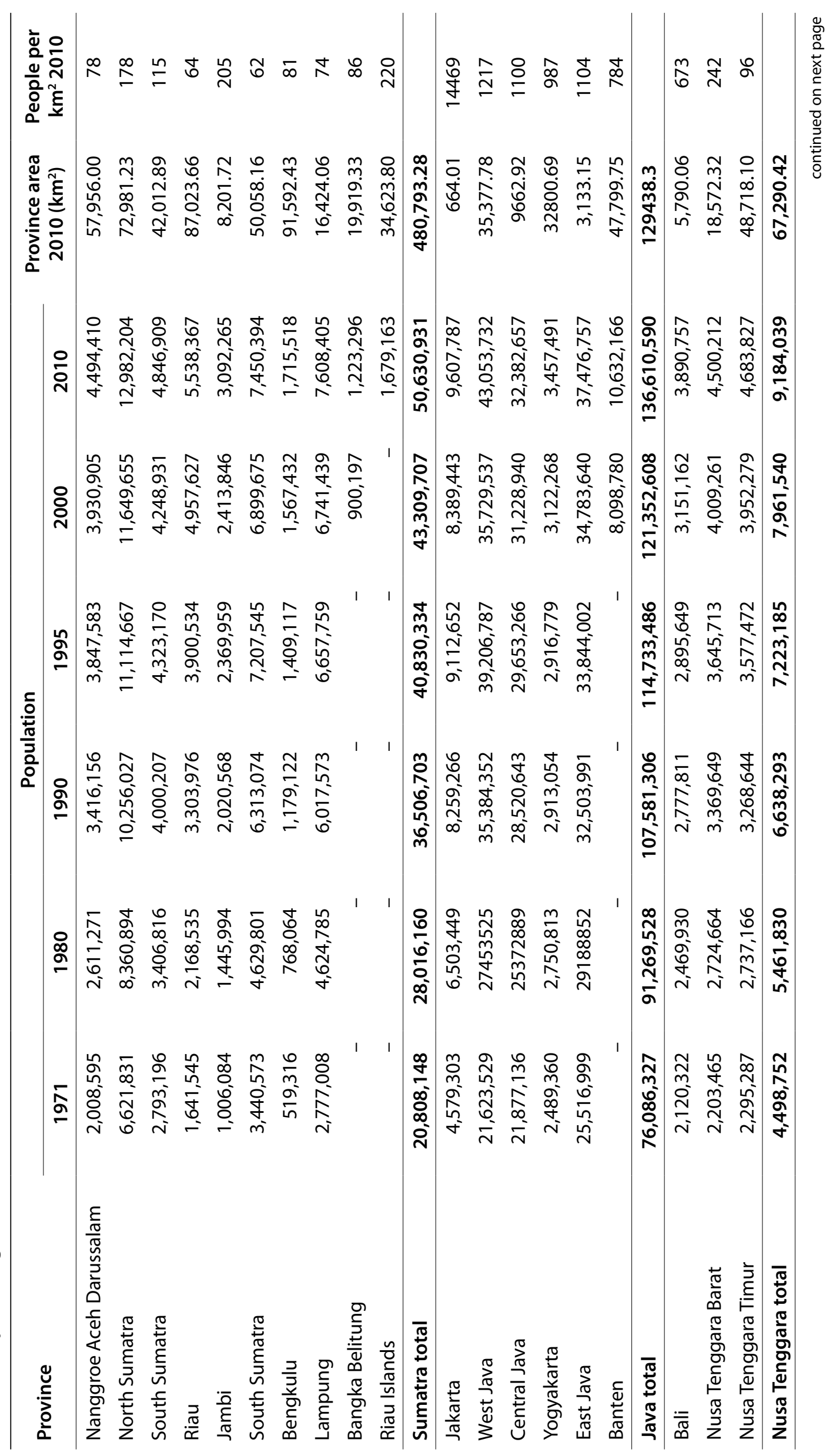




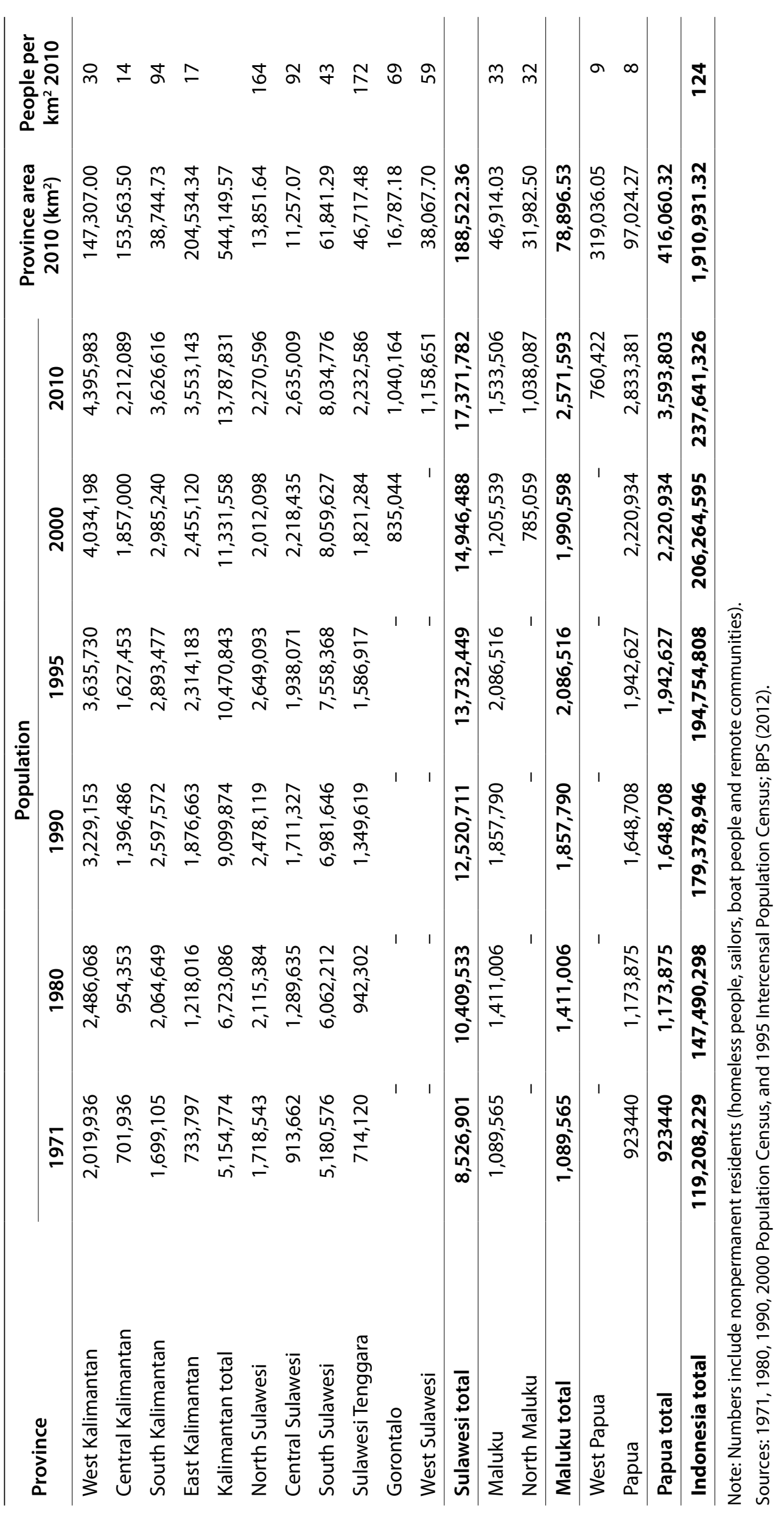


to agriculture. The dried-out peat and debris left behind by the project created ideal conditions for fire. Fires have plagued the area ever since (Barber and Schweithelm 2000; Boehm et al. 2001; Hoscilo et al. 2011). It was estimated that 15,600 families had been settled in 45 settlements in the area (Adhiati and Bobsien 2001).

Transmigration has also been linked to several nucleus estate projects (perkebunan inti rakyat). Under this scheme, transmigrants were sent to remote regions in Kalimantan, Sumatra and Papua to establish tree crop plantations (primarily acacia, rubber and oil palm). Transmigrants were supposed to be provided with land, houses and community facilities, but poor infrastructure, especially roads, inhibited the development of viable cash crop activities in some transmigrant centers (Pangestu 1991).

Transmigration projects tended to be situated in forested areas; around 1.8 million ha of forest was released for transmigration projects up until 1998. Javanese transmigrants often became shifting cultivators and collectors of forest products, particularly ironwood, because the poor soil on their small holdings gave them inadequate returns to support their families (Potter 1991).

Logged-over forest became the principal target area for settlements, and it soon became evident that clear-felling, to prepare land for transmigrant centers, was becoming a typical activity of the logging concessions or their contractors. There was growing criticism of the scope and cost of the transmigration schemes, as land for food-crop projects was becoming scarce and many schemes were of doubtful benefit to their participants. It was evident that much of the forest did not have suitable soil for farming and should not have been cleared, especially not with tractors, which were likely to strip off the shallow topsoil (Potter 1991).

Aside from the government-sponsored transmigration program, there has also been voluntary migration from the more populated islands to the outer islands. For instance, East Kalimantan has recorded one of the highest rates of population growth since 1970 due to migration (Pangestu 1991). The percentage of indigenous people in Sumatra, Kalimantan and Papua has declined in relation to migrants. In Papua, for instance, the proportion of indigenous people has fallen from around $96 \%$ to $76 \%$ (BPS 2012).
Population growth and the redistribution of people from Java to the outer islands has undoubtedly put pressure on Indonesia's forests, as many people rely on forests for their livelihood and the Indonesian government and other stakeholders rely on forests and other natural resources to drive economic development and generate revenue. Domestic consumption of forest products and crops that have replaced forests has also increased as Indonesia's population grows. For instance, domestic consumption of palm oil has increased from 2.8 million tonnes in 2001 to more than 7 million tonnes in 2012 (Bisinfocus 2012).

\section{Policy drivers of deforestation}

Deforestation began during the colonial era in Indonesia after the Dutch began to extract teak from Java's forests to build ships and sell to Chinese traders in the 17th century (Peluso 1992). Extraction was based on treaties with regional Javanese rulers, which enabled the Dutch to gain access to timber and local labor. Dutch traders and officials initially thought that Java's teak forests were inexhaustible, but most of those forests were exhausted by the end of the 18th century (Peluso 1992).

The 19th century was an important turning point in forest management as the colonial forest service determined the boundaries between forest and agricultural land — on maps and in the field — and established police forces to restrict people's access to trees and other forest products. Through a process of trial and error, regulations for profitable tree plantation management were encoded in colonial law, and local institutions governing forest access and property were gradually phased out of the legal discourse (Peluso 1992).

The 1865 forestry laws are said to be the first forestry laws for Java. These laws declared that all unclaimed and forest lands were the domain of the state. They also established procedures by which teak was to be logged, thinned and otherwise managed, and criminalized most traditional forest uses by forest villagers (Peluso 1992). This law was followed by the first Agrarian Law (Domeinverklaring) in 1870, which declared that all land that could not be proven to be owned (individually or communally) by villagers (i.e. land that was not currently under tillage or that had lain fallow for more than three years) was the property of the state. It allowed the state to issue 75-year leases to entrepreneurs for estate developments, primarily coffee, tea, rubber and oil palm (White 1983;

Potter 1991). 
The ideas of this period, and the impacts of these policies on the lives of forest-dwelling people, remain significant today as they laid the foundation for Indonesia's Constitution, ${ }^{12}$ the Basic Agrarian Law (UU5/1960) and the 1967 Basic Forestry Law (UU6/1967) (Poffenberger 1997). All of these laws reasserted the state's authority over the state-owned forest (kawasan hutan) - at that time, over 143 million ha, or $75 \%$ of the nation's land area - and subordinated the rights of customary communities to forest law and policy (Hermosilla and Fay 2005).

The 1967 Basic Forestry Law laid the basis for commercial exploitation of outer island timber by giving the state forestry bureaucracy the authority to grant a forest use right (bak pengusahaan hutan) to state-owned corporations and private investors in areas classified as production forest. This led to the emergence of large-scale conglomerates that were granted lucrative timber concessions (Dauvergne 1997), often at the expense of local community resource rights (Casson et al. 2007a).

Following the introduction of the Basic Forestry Law, log exports increased dramatically. The decade from 1970 to 1979 saw huge amounts of raw logs being exported, mainly to Japan, with $40 \%$ of the total originating in the single province of East Kalimantan. By 1979, Indonesia was the world's leading exporter of tropical logs, with $41 \%$ of the market (Barr et al. 2001).

The number of logging concessions issued rose from 71 in 1970 to 298 in 1976, stabilizing at approximately 580 throughout the 1980 s (Poffenberger 1997). In East Kalimantan alone, during the 1970s, over 100 forest logging leases ( hak pengusahaan hutan), totaling 9.8 million ha of coastal and riverine forests and representing over $50 \%$ of the province area, were granted (Poffenberger 1997). Logging resulted in heavy damage to the forest ecosystem in many concession areas during the $\log$ removal process, often severely affecting $40 \%$ to $70 \%$ of the remaining trees as well as seedlings and saplings (Poffenberger 1997).

Log exports came to an end in 1985 when the government imposed a national ban to discourage

12 Indonesia's Constitution establishes the basis of state authority over land and natural resources in Article 33, which states, "Land and water and the natural resources therein shall be controlled by the State and made use of for the greatest welfare of the people." exports and catalyze downstream investment in the production of plywood, pulp and paper. The ban was lifted after the 1997 economic crisis but reinstated in 2011.

The ban produced results, as the consumption of timber by wood-processing industries increased from 23.5 million $\mathrm{m}^{3}$ in 1985 to 50.5 million $\mathrm{m}^{3}$ in 2004 (World Bank 2006). The plywood industry grew rapidly from 29 plywood mills in 1980 to 111 mills in 1988 . By the early 1990 s there were over 130 plywood mills and Indonesia controlled about $80 \%$ of the world trade in tropical plywood (Dauvergne 1997). This level of consumption was unsustainable, and legal limits and industrial timber plantations began to be promoted to fill the supply-demand gap in the forestry sector (Brockhaus et al. 2012).

The industrial timber plantation scheme was designed to support the establishment of plantations of fastgrowing pulpwood species such as Acacia species ( $A$. mangium), Eucalyptus (E. pellita) and Gmelina ( $G$. arborea) and local species, with some experimentation with tropical hardwoods, to meet the needs of the plywood and pulp and paper industries. The scheme was financed by capital from the Reforestation Fund (Dana Reboisasi) generated through a tax on timber felled in natural forests (Poffenberger 1997).

Indonesia's decentralization policies (UU22/1999 on regional autonomy and UU25/1999 on fiscal balance) have also facilitated deforestation. These policies were released after the fall of Suharto to reform governance and allow district governments more say in decision making. They also allowed district governments to reap more economic benefits from natural resource extraction $-80 \%$ in the case of forest revenues. These policies gave rise to an increase in logging in areas that had previously been off limits. They also allowed district governments to reap financial benefits from issuing timber permits and allowing more logging to occur within their jurisdictions (McCarthy 2000; Barr et al. 2001; Casson 2001; Potter and Badcock 2001; Obidzinski and Barr 2002; Burgess et al. 2012). This situation was partly reined in when the Indonesian government revised the decentralization laws in 2004 (UU32/2004 and UU33/2004) to reassert the Ministry of Forestry's control over the state-owned forest and require district governments to coordinate their land use planning with provincial and national authorities.

The widespread allocation of Indonesia's forests for logging, timber plantations and oil palm estates has 
largely occurred due to the government's goal to use commodity investment to speed up econoomic development and modernization, often at the expense of local community resource and land rights. The rights of these people have slowly been addressed since the 2001 Decision of the People's Consultative Assembly on Agrarian Reform and Natural Resource Management called on the legislature and the president to implement policies on agrarian reform to make land allocation and control more equitable. Since then, community-based cooperatives have been able to obtain harvesting licenses to fell timber from production forests through a community forest utilization license (izin usaha pemanfaatan hutan kemasyarakatan), and the Ministry of Forestry has designated certain areas for the development of community timber plantations in degraded production forests. (This was stipulated in Indonesia's main implementing legislation on forest planning, management and use: PP34/2002, revised in 2007 with PP6/2007.) Communities have also been able to gain the right to manage areas of forest based on community practices and customary law (adat) (Kepmen 677/Kpts11/1998 on Community Forestry). Many are hopeful that the situation will improve further after the May 2013 ruling by Indonesia’s Constitutional Court that indigenous people's customary forests should not be classed as state forest.

Indonesia's forest policy environment is extremely complex, and various actors with particular agendas (as shown in Table 20) may create synergies as well as disagreements on forest areas to be used for production, conservation, or conversion.

Table 20. Key actors in Indonesian forest policy.

\begin{tabular}{ll}
\hline Actor & Responsibilities \\
\hline Ministry of Forestry & Issues laws, regulations and decrees to regulate the state-owned forest (kawasan \\
& hutan), $70 \%$ of Indonesia's total land area. Issues licenses for large-scale logging and \\
& industrial timber plantations; responsible for conservation areas and other protected \\
& areas. Monitors forest cover; determines forest functions. Regulates community- \\
& managed forests. Releases conversion forest land for agriculture, estate crops or \\
& other large-scale developments.
\end{tabular}

Ministry of Agriculture

Ministry of Environment

Ministry of Industry and Trade

District governments

President's Delivery Unit for Development Monitoring and Oversight (UKP4)

Ministry of Home Affairs

National Land Authority

Geospatial Information Agency

Ministry of Energy and Trade

National Development Planning Agency (Bappenas)

Coordinating Ministry for Economic Affairs
Responsible for food security and large-scale food estate developments such as the Merauke Food and Energy Estate planned for Papua. Promotes agricultural crops including oil palm, rubber and sugar.

Maps forest cover; conducts physical, social and environmental assessments of forest operations and processing facilities. Implements other environmental laws, such as the Environmental Management Act (UU23/1997), which establishes principles for environmental management and natural resource conservation and applies to logging operations and processing mills.

Regulates exports of processed timber and sawn timber.

Carry out district-based spatial planning; allocate concessions and licenses for land that does not fall within the state-owned forest, even if this land is forested. Regulate forest management in the districts (but these regulations cannot contradict laws or regulations issued by the Ministry of Forestry or other higher-level parties).

Monitors the implementation of REDD and the moratorium on logging of peat and primary forests; reports the results to the president.

Coordinates policy among national, provincial and district governments.

Carries out land administration and reform. Plays a role in the approval of concessions and other land permits, particularly in the non-state-owned forest.

Reviews spatial plans, provides standardized spatial data and oversees the One Map initiative.

Ensures domestic energy supply through fossil fuels and biofuels.

Carries out national development plans and the development master plan.

Carries out the development master plan. 


\section{Economic drivers of deforestation}

Since the 1970s, deforestation has been attributed to a number of economic drivers including large-scale logging, the conversion of forest into oil palm and industrial timber plantations, agricultural expansion, mining, road development, illegal logging caused by overcapacity in Indonesia's timber processing industry, and Indonesia's decentralization process (see Dauvergne 1998; Casson 1999; Hoffman et al. 1999; Siegert and Hoffman 2000; Casson and Obidzinski 2002; Page et al. 2002; Curran et al. 2004; Dauvergne 2004; Casson et al. 2007a; Langner et al. 2007; Koh and Wilcove 2008; Burgess et al. 2012) (Table 21). Unsustainable logging is generally considered to have been the main cause

Table 21. Key economic drivers of deforestation.

\begin{tabular}{|c|c|}
\hline Driver & Comments \\
\hline Oil palm expansion & $\begin{array}{l}\text { High oil palm prices and growing world demand have encouraged Indonesia to rapidly } \\
\text { expand oil palm plantations. Indonesia is now the largest producer of palm oil, followed by } \\
\text { Malaysia. Natural forest, particularly in conversion forest areas and on land outside the state- } \\
\text { owned forest, has often been cleared to make way for oil palm plantations, with the resulting } \\
\text { timber fed into Indonesia's timber processing mills. }\end{array}$ \\
\hline $\begin{array}{l}\text { Industrial timber } \\
\text { plantation expansion }\end{array}$ & $\begin{array}{l}\text { Industrial timber plantations have been promoted to supply Indonesia's timber processing } \\
\text { industry. These plantations were supposed to relieve pressure on natural forests, but they } \\
\text { have often replaced natural forest. }\end{array}$ \\
\hline Mining & $\begin{array}{l}\text { Large-scale and small-scale illegal mining occur within the state-owned forest and have an } \\
\text { impact on forests and the environment in general. }\end{array}$ \\
\hline $\begin{array}{l}\text { Overcapacity } \\
\text { of Indonesia's } \\
\text { processing industry } \\
\text { (illegal logging) }\end{array}$ & $\begin{array}{l}\text { Indonesia's timber processing industry requirements exceed sustainable limits and licensed/ } \\
\text { legal supplies of timber. Industrial timber plantations currently supply around } 28 \% \text { of } \\
\text { Indonesia's timber processing industry needs, which means that the remaining } 72 \% \text { is being } \\
\text { sourced from natural forests in all forest categories. Some of these forests are cleared to make } \\
\text { way for oil palm and industrial timber plantations. }\end{array}$ \\
\hline Decentralization & $\begin{array}{l}\text { Indonesia's decentralization policies initially created confusion and sparked widespread } \\
\text { deforestation as district governments thought they had the right to allocate clear-felling } \\
\text { and logging permits in forest areas that had previously been off limits. The revised } \\
\text { decentralization laws (PP34/2002 and PP6/2007) attempted to correct this situation; however, } \\
\text { they still allow district governments to generate revenues from logging and other forest- } \\
\text { clearing activities. Decentralization consequently offers poor but forest-rich districts an } \\
\text { opportunity to reap economic benefits from forest extraction. }\end{array}$ \\
\hline $\begin{array}{l}\text { Agricultural } \\
\text { expansion }\end{array}$ & $\begin{array}{l}\text { Indonesian economic policy stresses food self-sufficiency. This has resulted in several large- } \\
\text { scale agricultural developments that have destroyed forest, such as the mega-peat rice } \\
\text { project in Central Kalimantan. The Merauke Food and Energy Estate in Papua is also expected } \\
\text { to replace primary forest. Small-scale agriculture is also replacing forests in more populated } \\
\text { areas. }\end{array}$ \\
\hline Energy and mining & $\begin{array}{l}\text { Indonesia is a world leader in the production and export of copper, gold, nickel, silver and } \\
\text { coal. Large- medium- and small-scale mines have different environmental impacts, including } \\
\text { habitat loss, tailings and water pollution. Since 1967, many companies gained licenses } \\
\text { for exploration and mining development in the state-owned forest. Growing interest in } \\
\text { renewable fuels and biofuels is believed to have encouraged further investments in biofuel } \\
\text { crops, primarily oil palm. }\end{array}$ \\
\hline Roads & $\begin{array}{l}\text { Many see roads as important to facilitate development and reduce poverty by lowering } \\
\text { transport costs and providing access to health and education services, information and } \\
\text { markets. Roads can have direct environmental impacts including modifications to natural } \\
\text { drainage, vegetation cover and wildlife habitat, as well as landslides, erosion, sedimentation } \\
\text { and pollution. Roads through forested areas open the way for secondary impacts such as } \\
\text { encroachment, illegal logging, wildlife trade and land conversion through clearing or fire. }\end{array}$ \\
\hline Urbanization & $\begin{array}{l}\text { There has been a growing trend of rural dwellers moving into Indonesia's cities to seek better } \\
\text { living standards. It has been hypothesized that small farmers who become city dwellers tend } \\
\text { to consume more processed foods and animal products. These products are increasingly } \\
\text { coming from large-scale agricultural estates that have replaced forest. }\end{array}$ \\
\hline
\end{tabular}

Sources: Barber and Schweithelm (2000); World Bank (2006); Casson et al. (2007b); DeFries et al. (2010); Indrarto et al. (2012). 
of deforestation from around 1970 to 1990, while meeting demands for agricultural produce and export commodities are considered to be the primary causes of deforestation over the past decade (Ekadinata et al. 2011). All of these have exacerbated forest fires in degraded forest areas, which have caused further deforestation. ${ }^{13}$

Historically, Indonesia has promoted forest exploitation as a major revenue source (Potter 1991; Brockhaus et al. 2012). The forestry sector and associated industries have traditionally been perceived as important contributors to the national economy, but their contribution to GDP has been relatively small - below 1\% since 2002 (MoF 2012). This has historically been the case, even when largescale logging was at its peak. For instance, between 1984 and 1989, government income from all tariffs and royalties from forest exploitation remained insignificant, never exceeding $0.1 \%$ of the central government's total annual budget (Poffenberger 1997). It is true, however, that in the 1970s, largescale conglomerates that had been awarded logging and other concessions were at the center of economic development policy in Indonesia (Dauvergne 1998).

Nevertheless, the extraction of forest resources for economic development was emphasized in economic development plans released by the Suharto government, and it continues to be a strong theme in current economic development plans (Table 22). For instance, expansion of large-scale estate crops and timber plantations has been emphasized in the development master plan. This plan aims to utilize Indonesia's natural resources in the outer islands (Sumatra, Sulawesi, Kalimantan and Papua) to increase GDP from USD 700 billion (2010) to 17.5 trillion in 2045. Expansion of timber plantations and estate crops (primarily oil palm) will also be encouraged, particularly in Sumatra and Kalimantan, while food agriculture will be expanded in Papua and Sulawesi (Coordinating Ministry for Economic Affairs 2011). The development master plan is supported by the National Forestry Plan (20112030), which calls for 14.5 million ha of industrial timber plantation forests to be established to produce 362.5 million $\mathrm{m}^{3}$ of timber per year by 2030 . The natural forest is expected to be able to produce 14 million $\mathrm{m}^{3}$ per year (MoF 2011).

13 Significant fires occurred in 1982/1983, 1997/1998 and 2001/2002.
Repelita VII was the last of the Repelita development programs modeled on Suharto's New Order development policy. Subsequently, Repelitas were replaced by five-year Medium-Term Development Plans (Rencana Pembangunan Jangka Menengah), which coincide with presidential terms and are the building blocks of the 20-year LongTerm Development Plan (Rencana Pembangunan Jangka Panjang Nasional) 2005-2025 (Government of Indonesia 2004). The latter envisages heavy reliance on foreign investment to generate an annual growth rate of $7 \%-8 \%$. The investment is to be directed mostly to natural resource sectors with the emphasis on downstream processing and generating value added. The Medium Term Development Plans have the following foci:

- Plan 1 (2005-2009) - development blueprint preparation; ensuring peace and security; improvement of citizens' economic welfare

- Plan 2 (2010-2014) - improvement of human resources; improvement of in-house capacity for research and development; improvement of Indonesia's competitiveness in the context of regional economic integration

- Plan 3 (2015-2019) - development in the areas in which Indonesia has a comparative advantage, especially natural resources, agriculture and energy

- Plan 4 (2020-2024) - achievement of the goal of becoming a self-sustaining and developed country.

\section{Summary}

Considerable land cover change has occurred in Indonesia since the early 1970 s, when large-scale commercial logging concessions were established. Deforestation estimates vary considerably because analysis has been undertaken with different sensors and different methods and over different time periods. For 1970-1997, estimates suggest that between 1.2 and 2.6 million ha of forest was lost per year. Over the past decade, most estimates suggest that between 250,000 and 1.28 million ha of forest was lost per year. Deforestation seems to have waned over the last decade; this is likely to be because there is less forest available for clearing. However, estimates for the past decade may also be lower because many of the more recent estimates use moderate-resolution sensors, such as MODIS, which has a resolution of $250 \mathrm{~m}$, rather than Landsat, which has a resolution of $30 \mathrm{~m}$. Use of 
Table 22. Indonesia's five-year development plans, 1969-2004.

\begin{tabular}{|c|c|}
\hline Plan & Comments \\
\hline $\begin{array}{l}\text { Repelita I } \\
\text { (1969/1970 to } 1973 / 1974)\end{array}$ & $\begin{array}{l}\text { Forestry was treated as a subsector of agriculture. Repelita I promoted log exports } \\
\text { and increased foreign exchange earnings. }\end{array}$ \\
\hline $\begin{array}{l}\text { Repelita II } \\
\text { (1974/1975 to } 1978 / 1979)\end{array}$ & $\begin{array}{l}\text { This plan placed more emphasis on regional development and equity considerations. } \\
\text { It emphasized the contribution of forests to the economic development of } \\
\text { Indonesia's outer islands. Concessions were encouraged to develop processing } \\
\text { plants. Export taxes on log exports were doubled in } 1977 .\end{array}$ \\
\hline $\begin{array}{l}\text { Repelita III } \\
(1979 / 1980 \text { to } 1983 / 1984)\end{array}$ & $\begin{array}{l}\text { The emphasis shifted to local processing, with the phasing out of log exports } \\
\text { between } 1979 \text { and } 1985 \text {. Transmigration was seen as a means of invigorating outer } \\
\text { island economies as well as relieving some of the population pressure in Java. } \\
\text { The scale of transmigration increased markedly, with the number of sponsored } \\
\text { transmigrants settled in Kalimantan rising from } 103,700 \text { in } 1971 \text { to } 388,600 \text { in } 1980- \\
\text { 1985. Repelita III aimed to resettle } 2.5 \text { million people, primarily to Sumatra. }\end{array}$ \\
\hline \multirow[t]{2}{*}{$\begin{array}{l}\text { Repelita IV } \\
(1984 / 1985 \text { to } 1988 / 1989)\end{array}$} & $\begin{array}{l}\text { This plan emphasized the development of forest industries, rehabilitation and } \\
\text { improvement of the potential of forest resources through reforestation and } \\
\text { enrichment of natural forest lands, and rehabilitation of degraded lands. In 1985, raw } \\
\text { log exports were completely banned to encourage the development of Indonesia's } \\
\text { timber processing industry. }\end{array}$ \\
\hline & $\begin{array}{l}\text { Transmigration targets increased to } 750,000 \text { families, with } 80 \% \text { of sites to be in } \\
\text { forested locations. This did not materialize due to financial constraints and growing } \\
\text { criticism of the transmigration plan. During this period, the scale of government } \\
\text { involvement in transmigration was reduced. }\end{array}$ \\
\hline $\begin{array}{l}\text { Repelita V } \\
(1989 / 1990 \text { to } 1993 / 1994)\end{array}$ & $\begin{array}{l}\text { This plan stressed rapid development with emphasis on the industrial and } \\
\text { agricultural sectors. Major goals were food efficiency; increased agricultural } \\
\text { production, improvement and rehabilitation; conservation of forests; and } \\
\text { rehabilitation of degraded lands. The main purpose of the rehabilitation of } \\
\text { production forests through establishment of plantations was to support the } \\
\text { continuity of forest industries and promote export-oriented industries. The plan } \\
\text { called for creation of } 1.5 \text { million ha of plantations. It also prioritized agricultural } \\
\text { development (particularly oil palm) in the outer islands. }\end{array}$ \\
\hline $\begin{array}{l}\text { Repelita VI } \\
\text { (1994/1995 to } 1998 / 1999)\end{array}$ & $\begin{array}{l}\text { This plan encouraged foreign investment and abandoned high tariff barriers, } \\
\text { heavy regulation and import substitution policies. It introduced the concept of } \\
\text { sustainable development and aimed to stimulate non-oil export growth, particularly } \\
\text { in agriculture (including oil palm), to stimulate employment and GDP growth. } \\
\text { It encouraged higher forestry royalties and stumpage fees, reduced the timber } \\
\text { plantation target to } 1.25 \text { million ha and encouraged more sustainable management } \\
\text { of forest resources. The production target for logs was } 188.3 \text { million } \mathrm{m}^{3} \text {. }\end{array}$ \\
\hline $\begin{array}{l}\text { Repelita VII } \\
(1997 / 1998 \text { to } 2003 / 2004)\end{array}$ & $\begin{array}{l}\text { This plan was derailed by the } 1997-1998 \text { economic crisis, which caused GDP to fall } \\
\text { by } 13 \% \text { and caused the fall of Suharto. These changes gave rise to the reformasi era, } \\
\text { which sought to bring an end to corruption and allow more actors to benefit from } \\
\text { natural resource extraction. }\end{array}$ \\
\hline
\end{tabular}

Sources: Potter (1991); Byron (1993); World Bank (1994); Poffenberger (1997).

MODIS means that some deforestation will not be recorded. Inaccuracies also occur because most forest cover loss is quickly followed by forest cover gain in the form of timber and oil palm plantations. Analysis undertaken over five- to 10 -year periods rather than annually will therefore yield inaccurate results. Cloud cover also causes inaccuracies in land cover change analysis. Consistent annual analysis of a long historical period is urgently required to rectify some of these problems.
Timber extraction began with large-scale logging to generate export revenue, but it later fed Indonesia's growing timber processing industry, which has been encouraged to operate above sustainable timber supply limits. A variety of demographic, political and economic factors have driven this process and caused widespread deforestation. For instance, population growth has doubled in most regions and even quadrupled in Papua over the last 40 years. This has created increasing demand for timber products and 
driven local communities and governments to extract forest products to foster economic development, generate revenue and improve livelihoods.

High population density in already deforested islands, such as Java, also gave rise to Indonesia's transmigration program. This program was originally seen as a means to decrease population pressure on the overcrowded island of Java, but it later became a means for redistributing human resources to the outer islands to foster economic development. Many transmigration programs were poorly managed and funded, and this led to a range of environmental and social problems. Transmigration was also used to provide labor for nucleus estate projects, which have established plantations (primarily oil palm and timber) in remote forested regions in Kalimantan, Papua, Sulawesi and Sumatra.

A range of government policies have also been established to facilitate widespread and unsustainable forest extraction. Key laws originating in the colonial era (such as the Basic Forestry Law, UU5/1967) allowed the Indonesian state to assert its authority over $75 \%$ of the nation's land area and provided a basis for commercial exploitation of valuable timber species on the outer islands. They have also subordinated the rights of customary communities to forest law and policy. Other policies, such as the
1985 ban on $\log$ exports and the introduction of Indonesia's industrial forest plantation scheme, have helped to catalyze downstream investment in the production of plywood, pulp and paper. The decentralization of authority has also encouraged district governments and other local stakeholders to exploit forest resources to generate revenue.

Despite widespread deforestation and the range of social, environmental and economic problems that have originated from it, forest exploitation and plantation development continue to be strong themes in current economic development plans. The development master plan aims to utilize Indonesia's natural resources in the outer islands (Sumatra, Sulawesi, Kalimantan and Papua) to increase GDP from USD 700 billion in 2010 to 17.5 trillion in 2045. Expansion of timber, oil palm and other plantations is also encouraged, particularly in Sumatra and Kalimantan. The National Forestry Plan (2011-2030) also determines that the natural forest is expected to produce 14 million $\mathrm{m}^{3}$ of timber per year and that 14.5 million ha of industrial timber plantations will be established to produce 362.5 million $\mathrm{m}^{3}$ of timber per year by 2030 . Oil palm and other bioenergy feedstocks are being promoted by Indonesia's bioenergy policies, which seek to reduce dependency on fossil fuels. 


\section{The impact of plantation expansion on land use change and greenhouse gas emissions}

This section provides more detailed information and analysis on the impact of oil palm, industrial timber, and other plantations being promoted to develop bioenergy, on land use change over the past decade. It also reviews the impact of land use change on aboveground and below-ground GHG emissions.

\section{Oil palm and land use change}

The relationship between oil palm area expansion and land use change is complex, although it is generally thought that oil palm expansion has been a key driver of deforestation over the past 20 years. Data are varied and difficult to access; however, the Ministry of Forestry has estimated that close to $70 \%$ of oil palm plantations in Indonesia were planted on land that formally fell within Indonesia's state-owned forest between 1982 and 1999. This totaled close to 2.2 million ha of forest land (Casson 1999). Most of this forested land lay within the provinces of Riau, Jambi, Aceh, West Sumatra and Central Kalimantan. It can also be assumed that, before 1982, the great majority of Indonesia's oil palm plantations replaced forest as they were primarily established in Sumatra's plantation belt, which used to be forest (Casson 1999).

Criticism of Indonesia's oil palm sector and its impact on forests has encouraged the government in recent years to place temporary moratoriums on forest conversion (in 1998 and again from May 2011 to May 2013) and allocate more degraded land for oil palm developments. However, it is speculated that large areas of forest have still been cleared to make way for oil palm or under the auspices of oil palm. It has also been speculated that large areas of forest were cleared in anticipation of the most recent moratorium on conversion of primary forest and peatland (Lang 2013c). In some cases, oil palm companies have been given access to timber by acquiring a land-clearing permit or a location permit (izin lokasi), but have not gone on to plant oil palm, and have not incurred sanctions or penalties.

The Ministry of Forestry has made it more difficult for oil palm companies to acquire land-clearing permits in the state-owned forest in recent years, but forest land has continued to be released for plantations. Between 2006 and 2011, 1,012,799 million ha of land was released from the state-owned forest (conversion forest) for plantation development (Table 23). Most of this land ( $54 \%$ or $552,332 \mathrm{ha}$ ) was released in 2006, but 212,252 ha of forest land was also released in 2011. Most of the forest land released for plantation development was in Central Kalimantan (185,159 ha) and Riau (149,542 ha), where most deforestation has also occurred over the past decade (MoF 2012). Together these two districts accounted for $33 \%$ of the total forest land released for plantations between 2006 and 2011. Significant forest area was also released in Papua (131,000 ha) and West Papua (177,033 ha). Together these two districts accounted for $30 \%$ of the total forest area released for plantations between 2006 and 2011.

Access to forest was also facilitated by a spatial planning exercise carried out in 1999-2001 that

Table 23. Forest area released for plantations from 2006 to 2011.

\begin{tabular}{lr}
\hline Province & Area (ha) \\
\hline Aceh & 2,945 \\
North Sumatra & 69,569 \\
West Sumatra & 16,611 \\
Riau & 149,542 \\
Jambi & 174 \\
South Sumatra & 89,991 \\
West Nusa Tenggara & 5 \\
East Nusa Tenggara & 850 \\
West Kalimantan & 78,047 \\
Central Kalimantan & 185,159 \\
South Kalimantan & 52,190 \\
East Kalimantan & 16,350 \\
Central Sulawesi & 37,730 \\
Maluku & 4,049 \\
North Maluku & 1,533 \\
Papua & 131,000 \\
West Papua & 177,033 \\
\hline Total & $1,012,779$ \\
\hline
\end{tabular}

Source: MoF (2012). 
excised 13.4 million ha from the state-owned forest and redesignated it as nonforest land. Spatial analysis of this land indicated that around 35\%-40\% (4.85.4 million ha) of the total 134 million ha excised from the state-owned forest was forested (Casson et al. 2007b). Following the decentralization of government in 1999, governors and bupatis (district heads) were able to more easily allocate this forested land to oil palm companies, some of whom were genuine while others were only interested in gaining access to timber.

The Ministry of Forestry released another 5.2 million ha of forest from the state-owned forest for agriculture and plantation development between 2007 and 2011 (MoF 2012). The release of further forest land is likely to be facilitated by Government Regulation No. 10/2010 concerning the procedure for changing forest status and functions.

Available spatial data indicate that large areas of land have been allocated to oil palm companies on the islands of Kalimantan, Sumatra, Sulawesi and Papua and that 12.9 million ha of land has been allocated in principle for large-scale plantation development (primarily oil palm) in Indonesia (Table 24). Of this land, 62\% is in Kalimantan, 26\% in Sumatra, 8\% in Papua and 1\% in Sulawesi (Appendix 1).

Thirty percent (about 3 million ha) of the 12.9 million ha allocated in principle for large-scale oil palm plantations is forested, and around 2.2 million ha $(17 \%)$ is peat soil. Most of the forested land lies in Central Kalimantan (1.39 million ha) and West Kalimantan (699,255 ha); while most of the peat soil allocated for plantation developments lies in Central Kalimantan $(515,844)$, Riau $(497,249$ ha) and West Kalimantan (431,851 ha) (Appendix 1).

In addition to 12.9 million ha of land allocated in principle to oil palm companies, another 7.2 million ha of land use permits have been allocated for plantation development. This effectively means that over 20.1 million ha of land has been allocated for large-scale plantations (Table 24). The land use permits allow these companies to plant oil palm; most have been issued in the provinces of Central Kalimantan (2.1 million ha), East Kalimantan (1.3 million ha) and West Kalimantan (1 million ha). Of the land use rights issued to oil palm companies, $12 \%(874,433 \mathrm{ha})$ have been issued on peat soils, primarily in Riau and West Kalimantan (Appendix 1). Indonesia has approximately 21 million ha of peatland, which is $12 \%$ of its land area. Peatlands vary in thickness from 1 meter to 12 meters and store around $60 \mathrm{~kg}$ of carbon per $\mathrm{m}^{3}$ (Page et al. 2002).

These statistics indicate that enough land has already been allocated for planned oil palm developments to meet expected demand for CPO in 2020. If 10 million ha planted so far is sufficient to produce nearly 30 million tonnes of CPO, then 20.1 million ha that has been effectively allocated for plantations is significantly beyond what is needed to reach the 40 million ton CPO production mark by 2020 , which is the government's objective. There is no reason, therefore, to allocate more land to oil palm companies in the next 5-10 years. In fact, if all of the land allocated to oil palm developments was actually planted with oil palm, there could potentially be an

Table 24. Land allocated to oil palm plantations in Indonesia on peat and forested land until 2011 (ha).

\begin{tabular}{|c|c|c|c|c|c|c|}
\hline Region & $\begin{array}{l}\text { Peatland } \\
\text { via HGU }\end{array}$ & $\begin{array}{l}\text { Total land } \\
\text { via HGU }\end{array}$ & $\begin{array}{l}\text { Peatland } \\
\text { in principle }\end{array}$ & $\begin{array}{l}\text { Forested } \\
\text { land } \\
\text { in principle }\end{array}$ & $\begin{array}{l}\text { Total land } \\
\text { in principle }\end{array}$ & $\begin{array}{l}\text { Total land } \\
\text { via HGU and } \\
\text { in principle }\end{array}$ \\
\hline Kalimantan & 340,882 & $4,723,821$ & $1,112,275$ & $2,095,533$ & $8,157,201$ & $12,881,022$ \\
\hline Sumatra & 532,015 & $2,345,177$ & 896,528 & 162,163 & $3,471,416$ & $5,816,593$ \\
\hline Sulawesi & 0 & 109,196 & 0 & 54,914 & 170,716 & 279,912 \\
\hline Papua & 1,536 & 41,979 & 226,011 & 679,513 & $1,082,702$ & $1,124,681$ \\
\hline Other & 0 & 0 & 0 & 25,859 & 44,250 & 44,250 \\
\hline Total Indonesia & 874,433 & $7,220,173$ & $2,234,814$ & $3,017,992$ & $12,926,294$ & $20,190,708$ \\
\hline \multicolumn{7}{|c|}{$\begin{array}{l}\text { a Land use right. } \\
\text { b Includes mineral soils and peat soils. } \\
\text { c "in principle" refers to a provisional permit granted to an investor to carry out a feasibility study, impact assessment analysis anc } \\
\text { other studies to justify investment proposals. }\end{array}$} \\
\hline \multicolumn{7}{|c|}{$\begin{array}{l}\text { Sources: Forest cover 2009, Ministry of Forestry, peatland data from Wetlands International 2000-2004; estate crop data collected } \\
\text { from various sources at the provincial, national and district levels. }\end{array}$} \\
\hline
\end{tabular}


oversupply of palm oil on the market if this oil is not absorbed by the biodiesel industry. This oversupply could potentially affect $\mathrm{CPO}$ prices and the overall profitability of the crop.

\section{Industrial timber plantations and land use change}

Another significant cause of deforestation in Indonesia is thought to be the allocation of industrial timber plantations, particularly those whose establishment is at the expense of natural forests. In contrast to oil palm, industrial timber plantation concessions can only be allocated in the state-owned forest because it is assumed that these plantations are increasing forest cover within the state-owned forest and increasing timber supplies rather than decreasing forest cover. In principle, industrial timber plantations are intended to increase land productivity and therefore supposed to be planted on degraded production forest, with less than $20 \mathrm{~m}^{3}$ per hectare of commercial species with a diameter of $30 \mathrm{~cm}$ or more, to enhance timber stocks within the forest estate (Barr et al. 2010; Obidzinski and Dermawan 2012).

Statistical data on industrial timber plantations are difficult to access; however, a study carried out in 2005 estimated that around $80 \%$ of Indonesia's pulp and paper production was coming from natural forest and only $20 \%$ from industrial timber plantations. The same study speculated that deforestation caused by the pulp and paper industry has mainly taken place in proximity to the large mills located in Jambi, Riau and East Kalimantan (Jurgens 2007).
Estimating deforestation from the expansion of industrial timber plantations is extremely difficult for a number of reasons. One is that forest cover loss may be quickly followed by forest cover gain in the form of timber plantations, which grow 3-5 $\mathrm{m}$ annually during the first five years. The rapid recovery of forest canopies combined with the paucity of viable cloud-free observations makes it difficult to detect deforestation unless monitoring is carried out on a very regular basis (Margono et al. 2012). Moreover, the Ministry of Forestry considers tree plantations to be equivalent to natural forests, which means that the clearing of natural forest for the establishment of industrial timber plantations is not considered deforestation in Ministry of Forestry map data (Jurgens 2007).

While spatial data on industrial timber plantations are also limited, available spatial data suggest that around 8.9 million ha of land has already been allocated for industrial timber plantations (Table 25; Appendix 2). Most of this land is located in Riau (1.59 million ha), South Sumatra (1.52 million ha) and Central Kalimantan (1.4 million ha). Of the land allocated for industrial timber plantations, 21\% is thought to be peatland. Most of this peatland is located in Riau (922,871 ha), South Sumatra (587,286 ha) and West Kalimantan (243,634 ha). Spatial data also indicate that an additional 6.8 million ha has been issued for industrial timber plantations in principle. Fourteen percent of this land is located on peatland, and a staggering $42 \%$ ( 2.87 million ha) is located on natural forest. Most of this forested land can be found in Papua (743,591 ha), Central Kalimantan (401,579 ha) and West Kalimantan (384,040 ha). Altogether, spatial data indicate that 15.7 million ha of land has been

Table 25. Land allocated to timber plantations on peat and forested land to 2011 (ha).

\begin{tabular}{lrlrrrr}
\hline Region & $\begin{array}{l}\text { Peatland } \\
\text { already } \\
\text { allocated }\end{array}$ & $\begin{array}{l}\text { Total land } \\
\text { already } \\
\text { allocated }^{\text {alland }}\end{array}$ & $\begin{array}{l}\text { Peatland } \\
\text { allocated } \\
\text { in principle }\end{array}$ & $\begin{array}{l}\text { Forested land } \\
\text { allocated } \\
\text { in principle }\end{array}$ & $\begin{array}{l}\text { Total land } \\
\text { allocated } \\
\text { in principle }\end{array}$ & $\begin{array}{l}\text { Total land } \\
\text { allocated already } \\
\text { and in principle }\end{array}$ \\
\hline Kalimantan & 328,046 & $4,191,068$ & 232,130 & $1,112,187$ & $3,390,391$ & $7,581,459$ \\
Sumatra & $1,530,935$ & $4,141,322$ & 349,166 & 544,814 & $1,308,864$ & $5,450,186$ \\
Sulawesi & 0 & 65,725 & 0 & 268,130 & 475,634 & 541,359 \\
Papua & 67,635 & 369,170 & 441,424 & 822,074 & $1,419,516$ & $1,788,686$ \\
Other Indonesia & 0 & 176,869 & 0 & 131,575 & 229,977 & 476,846 \\
\hline Total Indonesia & $1,926,616$ & $8,944,154$ & $1,022,720$ & $2,878,781$ & $6,824,383$ & $15,768,534$ \\
\hline
\end{tabular}

a Includes mineral soils and peat soils.

Sources: Forest cover 2009, Ministry of Forestry, peatland data from Wetlands International 2000-2004; estate crop data collected from various sources at the provincial, national and district levels. 
allocated to industrial timber plantations and that $18 \%$ of this land (2.92 million ha) is located on peatland (Appendix 2).

\section{Deforestation and bioenergy feedstocks}

While the allocation of oil palm and industrial timber plantation permits appears to have resulted in considerable land use change in Indonesia and is expected to result in further land use change, the relationship between bioenergy feedstock development and tropical deforestation is complex. Concessions are allocated not only for bioenergy feedstocks but also for oil palm or industrial timber plantations which will primarily produce $\mathrm{CPO}$ and timber, wood chips, pulp and paper. No clear distinctions are made in statistical or spatial data sets, and specific figures on the amount of land dedicated to bioenergy feedstocks are not available. This is because feedstocks such as oil palm, timber, sugarcane and cassava are grown for various purposes, not only for bioenergy. While plantations for some biofuel feedstocks (such as oil palm and timber) have expanded in most provinces, little information is available about the commitment of specific areas to bioenergy production, or the proportion of existing plantations that is devoted to supplying the bioenergy industry (Caroko et al. 2011; Dermawan et al. 2012). Consequently, ascribing deforestation to a particular form of bioenergy is difficult (Gao et al. 2011). In fact, strictly speaking, no oil palm plantations have been developed exclusively for biodiesel production, since most supply conventional food markets. This may be different for industrial timber plantations, as some companies have applied for an industrial timber concession to produce wood pellets. ${ }^{14}$

The development of Indonesia's biofuel sector has also been slow; Indonesia missed the 2010 target for fuel blending and is predicted to fall behind on the 2015 and 2025 targets (Taylor and Supriatna 2013). Nevertheless, CPO-based biodiesel production is increasing, and Indonesia became the sixth largest

14 These are PT Bio Energy Indoco (21,000 ha in West Sulawesi), PT Bara Indoco (68,000 ha in West Sulawesi), PT Medco Papua Industri Lestari and PT Selaras Inti Semesta Medco Group (300,000 ha in Papua and Nusa Tenggara), and Carbon Positive and PT Usaha Tani Lestari $(160,000$ ha in Nusa Tenggara and Papua). In addition, there are other investing companies such as PT Solar Park Indonesia (Sumatra and Java), PT SaraRasa Bioindo (Riau) and PT Taiyoung Engreen (Central Kalimantan), but the land areas are not known. producer of biodiesel in the world in 2011. As discussed earlier, Indonesia is making progress with its biodiesel targets, and around $5.5 \%$ of its total oil palm plantation area is producing CPO-based biodiesel. The Indonesian government has also pledged to increase the biodiesel content to $10 \%$ from $7.5 \%$ in diesel oil sold to industrial users and motorists. For the power industry, the minimum was increased to 20\% (Taylor and Supriatna 2013). Global demand for biodiesel is increasing, and it is highly likely that oil palm developments will expand to meet demand. Wood pellet production is also likely to have an impact on deforestation because there is increasing interest in acquiring industrial timber plantations for wood pellet production; demand for wood pellets is growing in Japan, Korea and China. Sugarcane companies that have acquired around 420,000 ha of land in the Merauke Integrated Food and Energy Estate are also likely to clear forested land in this area.

Other bioenergy crops, such as jatropha and cassava, are expected to have minimal impact on deforestation over the next decade, as they are not expanding and have not proven to be profitable bioenergy feedstocks when compared with oil palm.

\section{Land use change and above-ground greenhouse gas emissions}

Conversion of natural forests to oil palm and timber plantations and other land uses not only results in biodiversity loss, and a range of environmental problems such as soil erosion and water pollution, but also increases carbon emissions. Forests sequester and store more carbon than any other terrestrial ecosystem. When they are cleared or degraded, their stored carbon is released into the atmosphere as $\mathrm{CO}_{2}$ (Gibbs et al. 2007). The largest source of GHG emissions in most tropical countries is deforestation and forest degradation.

Most of the carbon stored in tropical forests can be found in above-ground biomass (stems, twigs, leaves, vines, epiphytes and understory plants). It is also stored in dead trunks, standing dead trees, flowers, fruits and fire residues. Tropical forests store around $50 \%$ more carbon per hectare than boreal or temperate forests (Streck 2007).

The most direct way to quantify the carbon stored in above-ground living forest biomass is to harvest all trees in a known area, dry them and weigh the 
biomass (this is known as destructive sampling). Carbon content makes up about half of the dry biomass (Westlake 1966). While this method is accurate for a particular location, it is prohibitively time-consuming, expensive, destructive and impractical for country-level analyses (Gibbs et al. 2007). Carbon stocks can also be estimated by applying allometric equations to measurements of diameter at breast height alone or in combination with tree height (Brown et al. 1989; Ketterings et al. 2001; Chave et al. 2005).

No methodology has yet been developed to directly measure forest carbon stocks across a landscape.

Consequently, much effort has gone into developing tools and models that can scale up or extrapolate destructive harvest data points to larger scales based on proxies measured in the field or by remote-sensing instruments (e.g. Brown et al. 1989; Waring et al. 1995; Chave et al. 2005; Saatchi et al. 2007).

Available data on above-ground biomass in Indonesia's forests suggest that Indonesia's primary forests store around $230-250 \mathrm{Mg} / \mathrm{ha}$ of carbon while secondary forests store around $110-180 \mathrm{Mg}$. Oil palm plantations only store around $91 \mathrm{Mg} / \mathrm{ha}$ of carbon, ${ }^{15}$ and fast-growing timber plantations store around $60 \mathrm{Mg} / \mathrm{ha}$ (Table 26). This means that substantial carbon stored in the above-ground biomass of primary and secondary forests is lost when these forests are cleared. It also means that only a fraction of this carbon is restored when natural forest is replaced with fast-growing tree species or oil palm.

\section{Land use change and below-ground greenhouse gas emissions}

Indonesia has around 21 million ha of peatland, which is $11 \%$ of its land area (Table 27). Peat thickness varies from less than $1 \mathrm{~m}$ to over $20 \mathrm{~m}$ (Page et al. 2002). Data compiled by Wetlands International suggest that $42 \%$ of Indonesia's peatland areas are over $2 \mathrm{~m}$ thick (Hooijer et al. 2006). However, there is significant uncertainty about these data, as the thickness of the more remote and less well-mapped peatlands in Indonesia (particularly in Papua) is not well known (Hooijer et al. 2006; Page et al. 2011).

15 Ginoga et al. (2002) found oil palm to contain only around $27 \mathrm{Mg} /$ ha of carbon. However, this study accounted only for above-ground biomass, while the other studies factored in litter, soil and below-ground biomass.
Almost all lowland peat in Indonesia is derived from forest vegetation and has high wood content, but the degree of decomposition varies between and within peatlands (Page et al. 1999). This carbon store in peatlands can be released to the atmosphere as $\mathrm{CO}_{2}$ through two mechanisms: (1) drainage of peatlands, which leads to aeration of the peat and hence to oxidation (also called aerobic decomposition), and (2) fires, which usually only occur in degraded peatlands (Hooijer et al. 2006).

National levels of emissions from peat in Indonesia remain uncertain, although several studies have attempted to estimate them. For instance, Hooijer et al. (2006) used secondary data to estimate average annual $\mathrm{CO}_{2}$ emissions of $600 \mathrm{Mt} /$ year from peatland oxidation and $1400 \mathrm{Mt} /$ year from fire in Southeast Asia. They also estimated that $\mathrm{CO}_{2}$ emissions from peat subsidence peaked at $745 \mathrm{Mt} /$ year in 2005, followed by a steady decline over subsequent decades as the remaining peat deposits become depleted. This study emphasized the uncertainty associated with these estimates and outlined key knowledge gaps. In particular, understanding of the relationship between drainage depth, peat subsidence and emissions remains poorly developed.

Van der Werf et al. (2008) also used several approaches to estimate average annual $\mathrm{CO}_{2}$ emissions from peat and forest fires. Their mean annual estimate for 20002006 of $470 \mathrm{Mt} /$ year was used for the government of Indonesia's Second National Communication to the United Nations Framework Convention on Climate Change (UNFCCC) (MoE 2010).

Two of the main crops being planted on peat soils are oil palm and fast-growing timber. Both have increasingly been planted on peatlands because most of the suitable mineral soils in the lowlands within Sumatra and Kalimantan are already occupied with oil palm or other land uses. Peatlands also tend to have low population densities.

This situation may change now that Indonesia has placed a temporary moratorium on the conversion of primary forest and peatland. The government has placed this moratorium on the conversion of peatland because planting oil palm on peatland can lead to significant carbon emissions. This is because peatlands are compressed and drained to ensure that oil palm trees do not lean over and become susceptible to basal stem rot diseases caused by Ganoderma. This process leads to the irreversible drying and oxidation and gradual loss of peat soil. 
Table 26. Estimates of carbon stock by land use.

\begin{tabular}{|c|c|c|c|c|c|c|c|}
\hline Land use & $\begin{array}{l}\text { Carbon } \\
\text { stock } \\
\text { Mg/ha } \\
\text { Nunukan } \\
\text { (Rahayu et } \\
\text { al. 2005) }\end{array}$ & $\begin{array}{l}\text { Average } \\
\text { carbon } \\
\text { sequestered } \\
\text { tC/ha Jambi } \\
\text { (Ginoga et al. } \\
\text { 2002) }\end{array}$ & $\begin{array}{l}\text { Time- } \\
\text { averaged } \\
\text { carbon } \\
\text { stocks } \\
\text { Mg/ha } \\
\text { Jambi } \\
\text { (Murdiyarso } \\
\text { et al. 2002) }\end{array}$ & $\begin{array}{l}\text { Time- } \\
\text { averaged } \\
\text { above- } \\
\text { ground } \\
\text { carbon } \\
\text { stock } \\
\text { Mg/ha } \\
\text { Jambi } \\
\text { (Tomich et } \\
\text { al. 2002) }\end{array}$ & $\begin{array}{l}\text { Carbon } \\
\text { stock in } \\
\text { living plants } \\
\text { tC/ha } \\
\text { Central } \\
\text { Kalimantan } \\
\text { (Ludang and } \\
\text { Palangkajaya } \\
\text { 2007) }\end{array}$ & $\begin{array}{l}\text { Primary } \\
\text { forest with } \\
\text { significant } \\
\text { number of } \\
\text { large trees } \\
\text { (over } 70 \mathrm{~m} \text { ) } \\
\text { Mg/ha } \\
\text { Sebulu, } \\
\text { East } \\
\text { Kalimantan } \\
\text { (Yamakura } \\
\text { et al. 1986) }\end{array}$ & $\begin{array}{l}\text { Carbon } \\
\text { Mg/ha } \\
\text { Central } \\
\text { Kalimantan } \\
\text { (Murdiyarso } \\
\text { et al. 2010) }\end{array}$ \\
\hline Primary forest & 230.1 & - & 254 & 254 & & 501 & \\
\hline $\begin{array}{l}\text { Forest damaged } \\
\text { by commercial } \\
\text { logging }\end{array}$ & $184-212$ & - & 150 & 150 & $110-221$ & & \\
\hline $\begin{array}{l}\text { Forest damaged } \\
\text { by fire }\end{array}$ & & & & & $56-78$ & & \\
\hline Peat forest & & & & & $292-518$ & & \\
\hline $\begin{array}{l}\text { Forest under } \\
\text { community- } \\
\text { based } \\
\text { management }\end{array}$ & - & - & 176 & 176 & & & \\
\hline $\begin{array}{l}\text { Rubber, } \\
\text { traditional }\end{array}$ & - & 19.8 & - & - & & & \\
\hline Rubber clone & - & 42.4 & - & 103 & & & \\
\hline $\begin{array}{l}\text { Rubber } \\
\text { monoculture }\end{array}$ & - & - & 97 & - & & & \\
\hline $\begin{array}{l}\text { Rasin wood } \\
\text { gardens }\end{array}$ & - & 102.7 & - & - & & & \\
\hline Oil palm & - & 27.0 & 91 & 91 & & & \\
\hline $\begin{array}{l}\text { Fast-growing } \\
\text { pulp trees }\end{array}$ & - & - & 60 & - & & & \\
\hline Fallow rotation & $19.4-37.7$ & - & 74 & 74 & & & \\
\hline Agroforestry & $37.7-72.6$ & - & $103-150$ & - & & & \\
\hline $\begin{array}{l}\text { Imperata } \\
\text { grassland }\end{array}$ & 4.2 & - & 39 & 39 & & & \\
\hline Upland rice & 4.8 & - & 39 & - & & & \\
\hline Mangrove forest & & & & & & & 142.9 \\
\hline
\end{tabular}

A number of recent publications have addressed the GHG emissions associated with conversion of tropical peat swamp forest to oil palm plantations (Reijnders and Huijbregts 2008; Verwer et al. 2008; Ravindranath et al. 2009; Murdiyarso et al. 2010; Shirakawa et al. 2010; Hooijer et al. 2012). All conclude that while carbon losses from biomass replacement and land clearance are considerable, the large and sustained $\mathrm{CO}_{2}$ emissions from drained peat contribute most to overall emissions. The values used to estimate peat $\mathrm{CO}_{2}$ emissions have a wide range (19-115 $\mathrm{Mg} \mathrm{CO}_{2}-$ equivalent/ha/year) and are derived from a variety of sources, including Intergovernmental Panel on Climate Change (IPCC) defaults and a limited number of scientific studies (Appendix 9). 
Table 27. Peatland area by province.

\begin{tabular}{|c|c|c|c|}
\hline Province & Total land area (ha) & Total peatland area (ha) & Peatland $\%$ of total \\
\hline Kalimantan & $53,663,262$ & $5,867,378$ & 10.9 \\
\hline Central Kalimantan & $15,372,634$ & $3,111,779$ & 20.2 \\
\hline East Kalimantan & $19,815,040$ & 681,901 & 3.4 \\
\hline West Kalimantan & $14,736,286$ & $1,744,902$ & 11.8 \\
\hline South Kalimantan & $3,739,302$ & 328,796 & 8.8 \\
\hline Sumatra & $47,700,040$ & $7,205,221$ & 15.1 \\
\hline Bangka Belitung & $1,674,365$ & 63,473 & 3.8 \\
\hline Bengkulu & $2,020,335$ & 40,162 & 2 \\
\hline Jambi & $4,861,657$ & 710,679 & 14.6 \\
\hline Kepulauan Riau & 827,029 & 9,880 & 1.2 \\
\hline Lampung & $3,366,692$ & 90,885 & 2.7 \\
\hline Nanggroe Aceh Darussalam & $5,665,636$ & 283,449 & 5 \\
\hline Riau & $9,011,100$ & $4,109,133$ & 45.6 \\
\hline West Sumatra & $4,217,929$ & 208,800 & 5 \\
\hline South Sumatra & $8,754,353$ & $1,413,005$ & 16.1 \\
\hline North Sumatra & $7,300,944$ & 275,755 & 3.8 \\
\hline Sulawesi & $18,683,763$ & 0 & 0 \\
\hline Gorontalo & $1,198,409$ & - & - \\
\hline West Sulawesi & $1,689,723$ & - & - \\
\hline South Sulawesi & $4,544,862$ & - & - \\
\hline Central Sulawesi & $6,105,928$ & - & - \\
\hline Southeast Sulawesi & $3,685,166$ & - & - \\
\hline North Sulawesi & $1,459,675$ & - & - \\
\hline Papua & $41,630,555$ & $7,928,893$ & 19 \\
\hline Papua & $31,725,399$ & $6,986,489$ & 22 \\
\hline West Papua & $9,905,156$ & 942,404 & 9.5 \\
\hline Other Indonesia & $28,681,941$ & 0 & - \\
\hline Total for Indonesia & $190,359,561$ & $21,001,492$ & 11 \\
\hline
\end{tabular}

Sources: Hooijer et al. (2006.

According to Page et al. (2011), dependency on a limited number of flux studies, combined with inappropriate upscaling, has resulted in systematic underestimation of GHG emissions from oil palm plantations on tropical peat. Page et al. (2011) undertook a rigorous assessment of the empirical foundations, accuracy and validity of emissions estimates, tracing values used back to the original publications and evaluating the approaches and methodologies employed, to conclude that a value of $86 \mathrm{Mg} \mathrm{CO}_{2}$-equivalent/ha/year, annualized over 50 years, represents the most robust empirical estimate of peat $\mathrm{CO}_{2}$ emissions from oil palm and pulpwood plantations currently available, based on combined subsidence measurements and independent closed-chamber measurements in the same plantation landscape. Moreover, this estimate explicitly accounts for higher $\mathrm{CO}_{2}$ emissions observed in the early stages of plantation drainage. For a shorter annualization, the emissions would be higher following drainage of peat soils (see Table 28) (Page et al. 2011).

Other analysts consider these figures too high. For instance, Hergoualc'h and Verchot (2013) used a mass balance approach which included mean peat 
Table 28. Annual values for peat carbon losses from plantations over various time scales.

\begin{tabular}{cc}
\hline Number of years & $\begin{array}{l}\text { Carbon loss } \\
\text { (Mg CO }\end{array}$-equivalent/ha/year) \\
\hline 5 & 178 \\
10 & 121 \\
20 & 106 \\
25 & 100 \\
30 & 95 \\
40 & 90 \\
50 & 86 \\
\hline
\end{tabular}

Sources: Page et al. (2011); values derived from Hooijer et al. (2012).

carbon inputs through litterfall and root mortality and outputs via organic matter mineralization and dissolved organic carbon to estimate that total GHG losses were $30.4 \pm 10.6 \mathrm{Mg} \mathrm{CO}_{2}$-equivalent/ha/year for oil palm and $72 \pm 12.8 \mathrm{Mg} \mathrm{CO}_{2}$-equivalent/ ha/year for Acacia crassicarpa (Table 29). A single land-clearing using fire would result in additional emissions of $493.6 \pm 156.0 \mathrm{Mg} \mathrm{CO}_{2}$-equivalent/ ha. Acacia crassicarpa was estimated to result in high $\mathrm{CO}_{2}$ emissions because it is a nitrogen-fixing species and has a short rotation period (six years), which contributes to increased disturbance, soil aeration and soil organic matter decomposition. Nevertheless, Hergoualc'h and Verchot (2013) recommended further research to investigate the magnitude of nitrous oxide $\left(\mathrm{N}_{2} 0\right)$ emissions in $A$. crassicarpa systems planted on peat to confirm this estimate.

The 2013 Supplement to the 2006 IPCC Guidelines for National Greenhouse Gas Inventories on Wetlands also provided lower estimates for default Tier 1 emission/removal factors for drained organic soils. These figures were generated using a combination of subsidence and flux data found in the available literature. This supplement suggested that the average emission factor should be 15 tonnes of $\mathrm{CO}_{2} /$ ha/year for long rotation plantations on drained peat soil, 20 tonnes for short rotations of acacia plantations and 11 tonnes for oil palm plantations (Table 30).

\section{Summary}

The relationship between oil palm and industrial timber plantation expansion and land cover change is extremely complex and related to the overcapacity of Indonesia's timber processing industry. It is generally thought that the expansion of oil palm
Table 29. Annual net peat emissions from oil palm and acacia plantations ( $\mathrm{Mg} \mathrm{CO}_{2}$-equivalent/ha/year).

\begin{tabular}{lllll}
\hline & $\mathrm{CO}_{2}$ & $\begin{array}{l}\text { Methane } \\
\left(\mathrm{CH}_{4}\right)\end{array}$ & $\begin{array}{l}\text { Nitrous } \\
\text { oxide } \\
\left(\mathrm{N}_{2} \mathrm{O}\right)\end{array}$ & $\begin{array}{l}\text { Net } \\
\text { emissions }\end{array}$ \\
\hline $\begin{array}{l}\text { Oil } \\
\text { palm }\end{array}$ & $29.9 \pm 10.6$ & 0.0 & 0.5 & $30.4 \pm 10.6$ \\
Acacia & $71.8 \pm 12.7$ & $0.2 \pm 0.3$ & -0.0 & $72.0 \pm 12.8$ \\
\hline
\end{tabular}

Note: Values are mean \pm standard error and use 20-year global warming potentials.

Source: Hergoulac'h and Verchot (2013).

Table 30. Tier $1 \mathrm{CO}_{2}$ emission/removal factors for drained organic soils in selected land use categories.

\begin{tabular}{lc}
\hline Land use category & $\begin{array}{l}\text { Emission factor } \\
\text { (tonnes } \mathrm{CO}_{2} \text { ha/year) }\end{array}$ \\
\hline $\begin{array}{l}\text { Plantations, drained, } \\
\text { unknown or long rotations }\end{array}$ & 15 \\
$\begin{array}{l}\text { Plantations, drained, short } \\
\text { rotations (e.g. acacia) }\end{array}$ & 20 \\
Plantations, drained, oil palm & 11 \\
\hline
\end{tabular}

Source: IPCC (2013a).

and industrial timber plantations has been a primary driver of deforestation over the past decade. Ministry of Forestry data indicate that large areas of land have been released for conversion to plantations, and available spatial data indicate that significant areas of forest and peatland have been allocated for oil palm and industrial timber plantation development. Spatial data on oil palm indicate that companies have been awarded land use permits for 7.2 million ha of land and that $12 \%$ of this land is peatland. Most of the peatland is located in Riau and West Kalimantan. Another 12.9 million ha of land has been allocated in principle to oil palm companies. Of this land, 30\% (3.9 million ha) is forested (MOF 2009), and 17\% is peat soil. Most of the forested land lies in Central Kalimantan (1.39 million ha) and West Kalimantan $(699,255 \mathrm{ha})$, while most of the peat soil allocated for plantation development lies in Central Kalimantan $(515,844)$, Riau (497,249 ha) and West Kalimantan (431,851 ha).

Spatial data also indicate that 8.9 million ha of land has been allocated to industrial timber plantations (Table 31$)$ and that $21 \%$ (1.4 million ha) of this land is thought to be peatland. Most of this peatland is located in Riau $(922,871 \mathrm{ha})$, South Sumatra (587,286 ha) and West Kalimantan (243,634 ha). 
Table 31. Land allocated for oil palm and industrial timber plantations (ha).

\begin{tabular}{llll}
\hline & Oil palm & Timber & Total \\
\hline Land allocated in definitive licenses & $7,220,173$ & $8,944,154$ & $16,164,327$ \\
Peatland allocated in definitive licenses & 874,422 & $1,926,616$ & $2,801,038$ \\
Land allocated in principle & $12,926,294$ & $6,824,382$ & $19,750,676$ \\
Peatland allocated in principle & 891,907 & $1,022,720$ & $1,914,627$ \\
Forested land allocated in principle & $3,909,899$ & $2,878,781$ & $6,788,680$ \\
Total land allocated in definitive licenses and in principle & $20,146,467$ & $15,768,536$ & $35,915,003$ \\
\hline
\end{tabular}

Sources: a Bisinfocus (2012); b MoF (2012).

Note: A definitive license gives a company the legal right to develop a plantation. Allocation in principle means that the company does not yet have full rights to develop the land, but a provisional permit has been issued pending fulfillment of additional criteria.

Spatial data also indicate that an additional 6.8 million ha has been issued for industrial timber plantations in principle. Of this, $14 \%$ is located on peatland and $42 \%$ is located on natural forest, according to the Ministry of Forestry's 2009 land cover map. Most of this forested land is in Papua (743,591 ha), Central Kalimantan (401,579 ha) and West Kalimantan $(384,040 \mathrm{ha})$. Altogether, available spatial data indicate that $\mathbf{1 5 . 7}$ million ha of land has been allocated to industrial timber plantations in principle and that $18 \%$ of this (2.92 million) is located on peatland.

The amount of land allocated for future oil palm and industrial timber plantations is considerable (Table 31) and amounts to 19\% of Indonesias total land area. Much of this land is exempt from the Indonesian government's current moratorium on the conversion of primary forest and peatland, which is often seen as problematic and as limiting the utility of the moratorium.

Among the plantations issued in principle, 3.9 million ha of forested land has been allocated to oil palm companies and 2.9 million ha of forested land to industrial timber plantation companies. In addition to this, 2.23 million ha of peatland has been allocated in principle to oil palm companies and around 1 million ha of peatland has been allocated to industrial timber plantation companies; this amounts to $15 \%$ of Indonesia's total peatland area. It also appears that more definitive licenses have been issued to oil palm companies for 874,433 ha of peatland and to industrial timber plantation companies for 1.9 million ha of peatland. Combined, this means that a total of 6 million ha (or $28 \%$ of Indonesia's total peatland area) has been issued to oil palm and industrial timber plantation companies. This land cannot be protected by the current moratorium on the conversion of primary forests and peatlands.
Forests sequester and store more carbon than any other terrestrial ecosystem. When they are cleared or degraded, their stored carbon is released into the atmosphere as $\mathrm{CO}_{2}$. The largest source of GHG emissions in most tropical countries is deforestation and forest degradation. Only a fraction of the carbon (stored in above-ground biomass) that is lost when primary and secondary forests are cleared is restored when they are replaced with fast-growing tree species or oil palm. The situation is more dire for peatlands, as large and sustained emissions (estimated at 11 tonnes of $\mathrm{CO}_{2} /$ ha/year [IPCC 2013a]) arise from peat when it is drained and disturbed to make way for plantations.

While it seems clear that the allocation of oil palm and industrial timber plantation permits has resulted or is likely to result in considerable land use change in Indonesia, the relationship between bioenergy feedstock development and tropical deforestation is more complex. This is because concessions are not only allocated for biofuel feedstocks but are primarily established to produce $\mathrm{CPO}$, pulp and paper. There is no available information on the amount of land specifically allocated for bioenergy feedstocks, but this paper earlier estimated that around $5.5 \%$ of Indonesia's palm oil plantations $(494,744 \mathrm{ha})$ produced biodiesel in 2011. There is also evidence that some of the existing and planned industrial timber plantations are being established to produce wood pellets. The wood pellet market may experience some growth in Asian markets such as Korea, Japan and China. However, other biofuel crops, such as jatropha, cassava and sugarcane, are not experiencing growth and are therefore not likely to have a significant impact on land cover change over the next decade. 
This analysis is flawed in many ways as it relies upon incomplete spatial data, poor forest cover data and peat data that has not been verified on the ground. Nevertheless, it provides an alarming indication of land use and land use change in Indonesia. The figures presented here are also likely to be underestimates, as better and more complete data sets are likely to reveal that even more forest land and peatland has been allocated to industrial timber and oil palm plantations. Nevertheless, overlaps are evident among industrial timber and oil palm concessions, and correcting these overlaps may reduce the total area allocated for these two sectors. Investment in improving and harmonizing the accuracy of these data sets is critically needed to enable better assessment of the situation and determine appropriate policy measures.

A number of measures are being developed to reduce GHG emissions from land use change, and some of these measures are discussed in the following section. 


\section{Measures being taken to reduce adverse impacts}

Several measures are being undertaken to ensure that large-scale bioenergy plantations do not cause further unnecessary deforestation or other adverse impacts in Indonesia. Some of these measures are being taken internally, while others are being implemented by consuming countries or by organizations that promote sustainable bioenergy production. These measures include:

- a comprehensive review of land use permits issued in forest-rich provinces

- initiatives seeking to utilize degraded land;

- a moratorium on clearing of forests and peatlands with high biomass value

- promotion of projects seeking to reduce emissions from deforestation and land degradation

- national and regional mitigation action plans for reducing GHG emissions

- use of EIAs

- initiatives to encourage sustainable oil palm and biofuel feedstock production.

\section{Land use permit review}

One of the most significant efforts being undertaken in Indonesia to minimize unnecessary deforestation and improve GHG savings of biofuel feedstocks such as oil palm is a review of land use permits in several forest-rich districts, such as Central Kalimantan. This review is being led by UKP4. It was considered necessary because national agencies and local government offices have not shared information with each other on permits for logging, mining, palm oil development and other forest uses. As a result, multiple forest users may operate in the same area, creating confusion and conflict. The review will also determine if companies are operating in compliance with the law and have acquired the necessary legal documents to support their operations.

This review is considering a range of factors including the location of the concession (on forest, peat or degraded lands), overlapping land uses, data inconsistencies and the legal basis of permits that have been allocated. The Indonesian government has also launched an initiative known as One Map Indonesia (discussed in more detail below) to coordinate land allocation and spatial planning. These exercises may eventually lead to the revocation of a number of location permits and plantation business licenses, but the process is expected to be difficult and time consuming.

Spatial planning processes and the allocation of permits for oil palm and industrial timber plantations also need to be reviewed to ensure that degraded lands are optimized and permits are allocated for genuine plantations that comply with Indonesian law. There is some evidence that this will occur, as the Ministry of Forestry's National Forestry Plan for 2011-2030 indicates that degraded land will be considered in spatial planning exercises and in the allocation of land for plantations (Ministry of Forestry Regulation 49/ Menhut-II/2011 about National Forestry Planning [2011-2030]).

Between 1999 and 2001, large areas of conversion forest and limited production forest were excised from the state-owned forest when most of Indonesia's forest-rich provinces revised their spatial plans. These areas should have been degraded, but spatial analysis has revealed that $30-40 \%$ of them were forested. In 2004, governors were granted authority to issue land-clearing permits for lands falling outside the state-owned forest, and anecdotal evidence suggests that this process has allowed companies interested in gaining access to forested lands to obtain a permit to clear fell and sell timber under the auspices of establishing an oil palm or timber plantation. Some local governments have also issued land-clearing permits for forested land falling within the state-owned forest. This process has been used to generate revenues for provincial and district governments wishing to extract rents from companies interested in logging forested areas (Casson et al. 2007b).

The land use and permit review process will allow the government to review the legality of permits issued for large-scale agricultural developments and may lead to the revocation of some permits issued on forest land and peatland. 


\section{Efforts to optimize degraded land}

Research has shown that agricultural production can take place without substantial reduction of the store of organic carbon in the soils and vegetation of natural and managed ecosystems. Degraded and abandoned agricultural lands should consequently be used to grow native perennials, e.g. for bioenergy production, which could spare the destruction of native ecosystems and reduce GHG emissions. A number of initiatives have been launched in Indonesia to encourage the use of degraded land rather than virgin peat and forest land for plantation expansion. One of the most notable and innovative initiatives is known as the Palm Oil, Timber, Carbon Offset Initiative (see http://www.wri.org/our-work/ project/forests-and-landscapes-indonesia) — an initiative that aims to divert planned oil palm plantations in Indonesia away from natural forests and toward degraded or low-carbon areas. This initiative undertakes analysis to identify suitable and available degraded lands for estate crops. It then seeks to facilitate land swaps to allow companies that have been granted permits on forested land or carbon-rich land to use available degraded land instead.

Two legal mechanisms exist to enable land use swaps. The first is a revision of the local land use plan whereby the bupati proposes that treeless areas within the state-owned forest are excised and made available for other uses. The second is a true swap - the area removed from the state-owned forest is compensated for by the return of a similar or greater area of land designated as nonforest that has forest on it. The Palm Oil, Timber, Carbon Offset Initiative seeks to assess both the suitability and availability of the land. Gauging availability requires field trips and investigation into the legal status and current use of the land, to establish who owns the land, what entitlements local people deem important and what other claims exist. Spatial plans will reveal how the land is zoned by central, regional and local government. Indigenous peoples' traditional claims of land ownership and use rights are of particular importance.

Successful land swaps would allow companies to plant oil palm on degraded land rather than forested land. This would aid economic development, reduce carbon emissions and allow Indonesia to maintain its place as the world's leading producer of oil palm. Nevertheless, substantial political will and support is required, and a successful land swap has yet to be completed. A successful swap is critically needed to set a precedent and to create the incentives required to have this approach underpin the expansion of oil palm or other plantations in Indonesia.

Redirecting plantations onto degraded land is considered to be feasible because Ministry of Forestry statistics indicate that there is around 27.2 million ha of degraded land in Indonesia (MoF 2012). ${ }^{16}$ Only 7-9 million ha of this land is needed to secure a sustainable supply of palm oil for global and domestic markets.

Much of this degraded land lies within the lands in some provinces that is earmarked for conversion for instance, Central Kalimantan, West Kalimantan, South Sumatra, North Sumatra and Papua (Figure 24). Some of these lands could potentially be rehabilitated and planted with oil palm or other biofuel feedstocks to make them economically productive. ${ }^{17}$

The Indonesian government has issued several policies to support the use of degraded lands for plantation developments. For instance, Presidential Instruction No. 1/2006 instructs the Ministry of Forestry to allocate degraded forest lands for biofuel crop developments. The National Biofuel Team also determined that Indonesia has vast areas of degraded land that can be converted to raising biofuel feedstocks. To ensure that policies promoting the use of degraded land are effective, contradictive policies promoting the use of forested lands for oil palm developments (such as Article 19 of Government Regulation 10/2010) need to be revised.

Directing biofuel feedstock expansion onto degraded land can be complex. Oil palm companies have traditionally preferred to convert forest lands and peatlands because they can profit from felling timber on these lands and because these lands are relatively unpopulated. In contrast, degraded lands have already been occupied and subjected to logging, shifting cultivation or other uses. People conducting these activities are likely to be occupying some of the lands. Some will have planted crops on these lands

16 There is no single definition of degraded land in Indonesian law or policy. The term usually refers to areas with low carbon stocks and low biodiversity levels, rather than characteristics related to agricultural stability or legal availability. This understanding is problematic because it would include areas that are currently under cultivation or are locally important for social and cultural reasons.

17 Degraded land in Nusa Tenggara Timor would not be suitable for oil palm developments. 


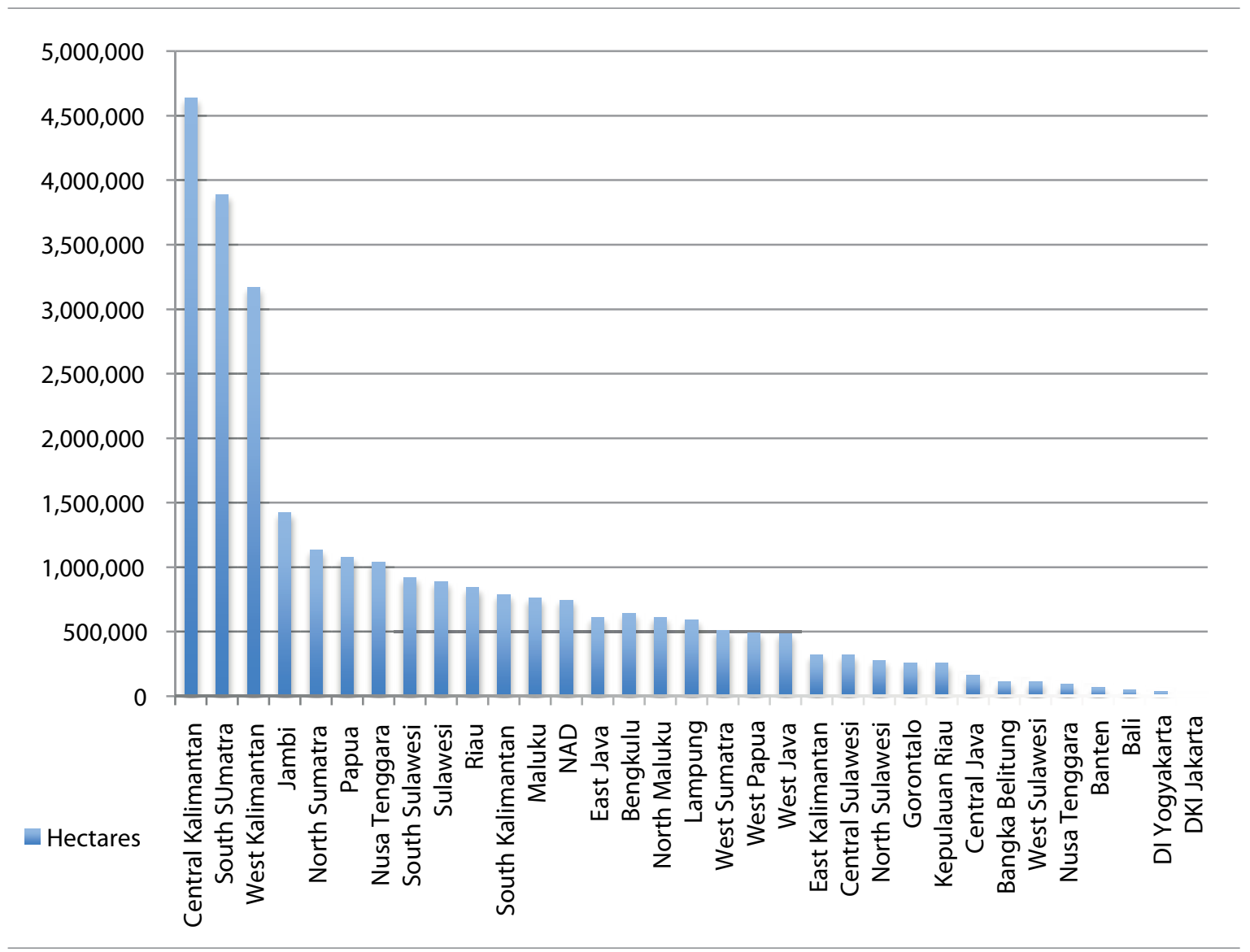

Figure 24. Degraded land area by province (ha). Source: MoF (2012).

and may have legitimate rights to use them (Casson et al. 2007b). Consequently, community mapping and participatory spatial planning exercises may need to be undertaken to ensure that degraded lands can be utilized prior to allocating concessions on them.

Moreover, degraded lands may have already been allocated to agricultural companies or other enterprises in poor spatial planning processes that were not documented in a central database. Currently, accurate and reliable information about allocated plantation concessions and community lands is lacking, and overlapping concessions have been issued in a number of areas. Extensive support is needed to improve spatial data before it will be possible to effectively use spatial planning processes to redirect oil palm concessions onto degraded lands. Finally, it is likely that some of the degraded lands are peatlands, which should be rehabilitated and reserved for conservation (Casson et al. 2007b).

In Indonesia, it has been suggested that degraded land needs to be identified using a range of criteria including carbon and biodiversity values, soil and water properties, crop productivity, financial viability, zoning (i.e. oil palm cannot be planted in protection or conservation forest), land rights (particularly the rights of indigenous and local communities), land use and local interests. These criteria can be assessed relatively quickly with available spatial data, but they need to be verified with field checks.

Increased costs may be incurred from converting imperata grasslands to oil palm, as the grass needs to be removed with herbicides and greater inputs of fertilizers and pesticides are usually needed in the first three years of the plantation's life. However, planting oil palm on grasslands would result in a win-win situation overall, because oil palm developments would effectively turn degraded wastelands into profitable plantations. Small carbon benefits could also potentially be gained from planting oil palm on degraded lands, as research carried out in Sumatra and Kalimantan has demonstrated that grasslands with Imperata cylindrica, a species native to the tropics and warm temperate regions worldwide, 
contain around $39 \mathrm{Mg} / \mathrm{ha}$ of carbon, while oil palm contains around $91 \mathrm{Mg} / \mathrm{ha}$ (Murdiyarso et al. 2002).

Overall, efforts to redirect plantation developments from peat and natural forest land to suitable, carefully assessed degraded lands can potentially reduce GHG emissions and stimulate economic development if care is taken to ensure that local community rights are evaluated and accommodated.

\section{Moratorium on clearing of forests and peatlands}

Indonesia has sought to reduce deforestation from the expansion of biofuel feedstocks and other largescale developments by imposing a moratorium on clearing primary natural forests and peatlands. This policy was initially established in May 2011 under a USD 1 billion condition-based climate deal with Norway aimed at reducing emissions from deforestation. ${ }^{18}$ This moratorium is designed to allow time for the government to develop improved processes for land use planning and permitting, strengthen data collection and information systems, and build the institutions necessary to achieve Indonesia's lowemission development goals (Austin et al. 2012).

Some primary forest and peatland areas were exempt from the moratorium because they had already been allocated to concessionaires in principle by the Ministry of Forestry, regardless of their richness in carbon, biodiversity or other ecosystem services, or because the land was needed for vital national development projects such as food security. The moratorium can only protect primary forest and peatland areas from new investments.

The Ministry of Forestry published an Indicative Map for Suspension of New Licenses in July 2011; this map has been revised four times since then by

18 This policy was legitimated by presidential instruction Inpres $10 / 2011$ on "the postponement of the issuance of new licenses and improving governance of primary natural forest and peatland." After the letter of intent with Norway was signed, a REDD+ task force was formed within UKP4 to implement it. Within this task force, working groups were established to focus on the following 10 areas: national strategy; monitoring, reporting and verification (MRV) design and development; funding; design of a REDD+ agency; REDD+ piloting in Central Kalimantan; legal review and enforcement; communications and stakeholder engagement; moratorium monitoring; mainstreaming REDD+ programs into the national program; and knowledge management (Lang 2013a). The task force's mandate ended at the end of 2012; it is supposed to be taken over by the REDD+ agency, the creation of which is still pending. a multidisciplinary team with members from the Forestry Ministry, Agriculture Ministry, National Land Agency and Geospatial Information Agency. The initial moratorium map (known as Version 0) was analyzed by several parties, including the World Resources Institute and the Center for International Forestry Research (Murdiyarso et al. 2011; Austin et al. 2012). According to Murdiyarso et al. (2011), the moratorium would temporarily protect a total of 66.4 million ha of forested land or peatland, ${ }^{19}$ including around 7.2 million ha of primary forest and 11.2 million ha of peatland that was not already included in Indonesia's conservation and protected forest categories. It was estimated that 5.8 million ha of peatland (29\% of the country's total peatland) was not included in the original moratorium map, presumably because existing permits had been issued prior to the enactment of the presidential instruction, or the excluded areas were required for food security. Also excluded from the original moratorium map was 9.6 million ha of primary forest $(21 \%$ of the total remaining primary forest), of which 4.1 million ha was limited production forest, 3.4 million ha was production forest and 1.8 million ha was conversion forest. Similarly to the peatland case, these primary forest areas are most likely under concessions granted prior to the release of Presidential Instruction No. 10/2011 (Murdiyarso et al. 2011).

The moratorium maps have received a great deal of attention and have been reviewed and assessed by multiple parties including companies that had been issued licenses within the moratorium areas, NGOs and government institutions such as the Land Authority, Ministry of Agriculture, Ministry of Mining and Energy, Ministry of Public Works and district governments (Lang 2013a). Satellite imagery and field surveys have also been used to refine the moratorium map (Lang 2013a). Stakeholders generally thought that the two-year moratorium provided an opportunity for the government and other stakeholders to strengthen the governance of forests and embark on a low-emission development pathway. However, it has also been criticized because it allowed exceptions for existing concessions. Many also criticized the moratorium for not including secondary forests, which can also have high carbon content and be rich in biodiversity (Murdiyarso et al. 2001; Austin et al. 2012; Lang 2013d).

Although consistent analysis of the moratorium maps is not currently available, it appears that

19 Austin et al. (2012) estimated that 68.8 million ha would be protected under the moratorium. 
comments from various parties have resulted in the original moratorium area being reduced by around 1.8 million ha. While some areas have increased (primarily areas already included in protected areas and nature reserves), the peatland area appears to have been reduced from an estimated 11.2 million ha in Version 0 to 4.9 million ha in Version 4 (Table 32). It has been reported that the peatland area of Papua was reduced after the Ministry of Agriculture argued that the Wetlands International peatland map that had been used to create the initial version of the moratorium map was inaccurate and had not been ground-truthed. The peatland data were consequently replaced, for the second version of the map, with data from the Ministry of Agriculture (Lang 2013d). In the fourth revision of the moratorium map, forest land was also reduced in the Merauke Integrated Food and Energy Estate area in Papua; it has been speculated that this was done to accommodate permits that had been issued to companies planning to develop sugar plantations in the area (Awas MIFEE 2013).

The first moratorium expired in May 2013, and an extension was hotly debated. In late 2012, Indonesian lawmakers in the House of Representatives' Commission IV dealing with forestry, agriculture, fishery and food sectors threatened to freeze the budget for reforestation projects if President Susilo Bambang Yudhoyono extended the moratorium until 2014. Palm oil planters also denounced the moratorium, saying it had throttled palm oil production (Mattangkilang 2013). Evidence presented in this paper suggests this is an exaggerated claim. The Ministry of Forestry recommended that the moratorium stay in effect until the 2014 presidential election (Pasandaran 2012). Others encouraged the government to extend the moratorium and to expand the ban on new forestry concessions to include Indonesia's vast secondary forests and carbon-rich mangroves. The moratorium was finally extended in mid-May 2013, and it continued to only protect primary forests and peatlands from conversion (Lang 2013a).

The moratorium policy has had many positive outcomes aside from the temporary protection of peatland and primary forest. For instance, it has reinforced and highlighted the need for the One Map initiative (discussed in more detail in the following section). When the moratorium map was in the development stage, it was realized that different agencies were using different land cover maps to indicate where primary forest and peatlands lay. A process of consultation and discussion was held to agree on the development of one moratorium map. The map was primarily created using Ministry of Forestry data. The head of UKP4, Kuntoro Mangkusubroto, has admitted that the moratorium map is far from perfect, but he pledged that the government would continue to improve it and to solicit input from local people and organizations (Lang 2013a). He also heralded the moratorium as an "extraordinary achievement considering that many

Table 32. Moratorium map revisions.

\begin{tabular}{|c|c|c|c|c|c|c|}
\hline Version & $\begin{array}{l}\text { Date of release } \\
\text { (purpose) }\end{array}$ & $\begin{array}{l}\text { Government } \\
\text { regulation }\end{array}$ & $\begin{array}{l}\text { Land } \\
\text { included in } \\
\text { moratorium } \\
\text { (ha) }\end{array}$ & $\begin{array}{l}\text { Primary forest } \\
\text { not already } \\
\text { protected } \\
\text { (ha) }\end{array}$ & $\begin{array}{l}\text { Peatland } \\
\text { (ha) }\end{array}$ & $\begin{array}{l}\text { Forest already } \\
\text { protected in } \\
\text { conservation forest } \\
\text { or nature (ha) }\end{array}$ \\
\hline 0 & $\begin{array}{l}17 \text { June } 2011 \\
\text { (original) }\end{array}$ & $\begin{array}{l}\text { SK 323/ } \\
\text { Menhut-11/2011 }\end{array}$ & $66.400,000^{\mathrm{a}}$ & $7,200,000^{\mathrm{a}}$ & $11,200,000^{a}$ & $43,900,000^{\mathrm{a}}$ \\
\hline 1 & $\begin{array}{l}22 \text { November } \\
2011 \\
\text { (revised) }\end{array}$ & $\begin{array}{l}\text { SK 7416/Menhut- } \\
\text { VII/PSDH/2011 }\end{array}$ & $65,486,593$ & $--^{b}$ & $--^{\mathrm{b}}$ & $--^{\mathrm{b}}$ \\
\hline 2 & $\begin{array}{l}28 \text { May } 2012 \\
\text { (revised) }\end{array}$ & $\begin{array}{l}\text { SK 2771/Menhut- } \\
\text { VII/PSDH/2012 }\end{array}$ & $65,360,967$ & $8,234,024$ & $5,836,555$ & $51,290,387$ \\
\hline 3 & $\begin{array}{l}28 \text { November } \\
2012 \\
\text { (revised) }\end{array}$ & $\begin{array}{l}\text { SK 6315/Menhut- } \\
\text { VII/IPSDH/2012 }\end{array}$ & $64,874,724$ & $7,735,710$ & $5,416,958$ & $51,722,055$ \\
\hline 4 & $\begin{array}{l}16 \text { May } 2013 \\
\text { (extended for } 2 \\
\text { years) }\end{array}$ & $\begin{array}{l}\text { SK 2796/Menhut- } \\
\text { VII/IPSDH/2013 }\end{array}$ & $64,670,672$ & $7,465,395$ & $4,935,465$ & $52,269,811$ \\
\hline
\end{tabular}

a No figure was specified in the regulation. This figure was estimated by Murdiyarso et al. (2011).

b No figure was specified in the regulation, and no other data are available. 
institutions and ministries previously used different maps as the basis for the issuance of various management permits."

The moratorium map has also encouraged provincial and district leaders to protect carbon-rich areas. For instance, the governor of East Kalimantan decided to declare a moratorium on the issuance of further permits for mining, plantations and logging in early 2013. The moratorium was issued via Instruction No. $180 / 1375-\mathrm{HK} / 2013$ to allow the provincial government to audit and review existing permits and determine if they were issued correctly and in accordance with the law. Any permits found not to be in compliance with the law or to be tainted by other problems will be revoked. The review aided the national government's efforts to review land use permits in the area and was considered necessary because excessive numbers of permits had been granted. According to provincial data, 1480 mining use permits (izin usaha pertambangan), 32 coal work permits (perjanjian karya pengusahaan pertambangan batu bara), 351 mining authorization permits (kuasa pertambangan) and 260 exploration permits have been issued for more than 3 million ha of land. Moreover, 2.4 million ha of land has been issued for plantations, but only 1 million ha is thought to have been utilized to date (Karim 2013).

Other provincial leaders, such as the governor of Aceh, are not fully complying with the moratorium, and NGOs, such as the Coalition of Aceh Rainforest Movements, are accusing the Ministry of Forestry of rezoning forest areas into nonforest areas through spatial planning bylaws and ministerial decrees that will allow the conversion of around 1.2 million ha of Aceh's existing 3.78 million ha of protected forest into nonforest areas. The governor of Aceh has disputed these figures and has declared that only 119,000 ha of forest will be affected by the new spatial planning bylaw. Ministerial Decree No. 458/2012 was also issued in late 2012 to allow around 800,000 ha of protected forest in Papua to be converted into production forest (Natahadibrata 2013).

Recent deforestation analysis published in Science also suggests that deforestation increased to 2 million ha in 2011/2012 (Hansen et al. 2013). It has been speculated that forest was rapidly cleared before it was placed off limits by the moratorium (Lang 2013d).

All of the moratorium maps have been made available to the general public on a website (http:// webgis.dephut.go.id/). This allows multiple parties to review and comment on the maps, and it will help the government to improve the maps over time so that they can be more accurate and binding. The review process is also allowing the government to review any data inconsistencies or illegal permits.

The moratorium is only a temporary measure, which is currently buying the government time to harmonize map data, review permits and resolve data inconsistencies. Peatland and primary forest areas not already included in protected areas may still be able to be accessed by concessionaires once the moratorium expires. A more permanent measure is therefore required to protect these areas (estimated to be 7.4 million ha of primary forest and 4.9 million ha of peatland by the fourth revision of the moratorium map). The fate of carbon-rich areas that are not included in the moratorium already seems to be clear - these lands can be accessed and are likely to be deforested or cleared in the future.

\section{The One Map initiative}

Spatial data on Indonesia are scattered in various agencies at different levels of government and in various NGOs, research institutions and companies. This makes it extremely difficult for any level of government to undertake accurate and well-informed spatial planning, allocate concessions and ensure that high-conservationvalue forests and lands with high carbon content are adequately protected. Spatial information became particularly scattered after Indonesia embarked on decentralization in 1999. Decentralization gave district governments more say in spatial planning processes and allowed them to generate their own spatial data on concessions, forest cover, peatland and even district boundaries. Much of this information is not passed on to provincial or national governments. National and provincial governments also have a poor track record when it comes to informing district governments about land they have allocated. At different levels of government, different methods have been used to calculate forest cover and forest allocations. For instance, at the national level, six institutions produce land cover maps in different ways and with different results. Most of these maps are based on Landsat analysis, but they use different land classes (Table 33).

This situation has given rise to differing figures on forest cover and forest types (land classes). For instance, a presentation by UKP4 revealed significant differences between the Ministry of Environment and Ministry of Forestry 2009 land cover maps (Table 34). These discrepancies were particularly evident in Papua (Figure 25). 
Table 33. Government institutions generating land cover maps in Indonesia.

\begin{tabular}{|c|c|c|c|c|}
\hline Ministry & Satellite imagery & Map scale & Updates & $\begin{array}{l}\text { Number of } \\
\text { land classes }\end{array}$ \\
\hline $\begin{array}{l}\text { Coordinating Agency } \\
\text { for National Survey and } \\
\text { Mapping (Bakosurtanal) }\end{array}$ & Landsat & $\begin{array}{l}1: 25,000 \\
1: 100,000\end{array}$ & Every 3 years & 21 \\
\hline Transmigration & Landsat & $\begin{array}{l}1: 250,000 \\
1: 100,000\end{array}$ & $\begin{array}{l}\text { Information not } \\
\text { available }\end{array}$ & 23 \\
\hline Forestry & Landsat & $1: 50,000$ & Every 3 years & 23 \\
\hline Environment & Landsat & $1: 100,000$ & Every year & 15 \\
\hline $\begin{array}{l}\text { National Institute of } \\
\text { Aeronautics and Space } \\
\text { LAPAN }\end{array}$ & Landsat, SPOT, Alos & $\begin{array}{l}1: 50,000 \\
1: 100,000\end{array}$ & Every year & 18 \\
\hline National Land Authority & Landsat & $1: 100,000$ & - & 18 \\
\hline
\end{tabular}

Source: Authors, various sources.

Table 34. Differences between the 2009 Ministry of Forestry and Ministry of Environment land cover maps.

\begin{tabular}{lcc}
\hline Ministry & Primary and secondary forest (million ha) & Primary forest (million ha) \\
\hline Environment & 112.4 & 59.8 \\
Forestry & 100.6 & 44.2 \\
\hline
\end{tabular}

Source: UKP4 (2012).

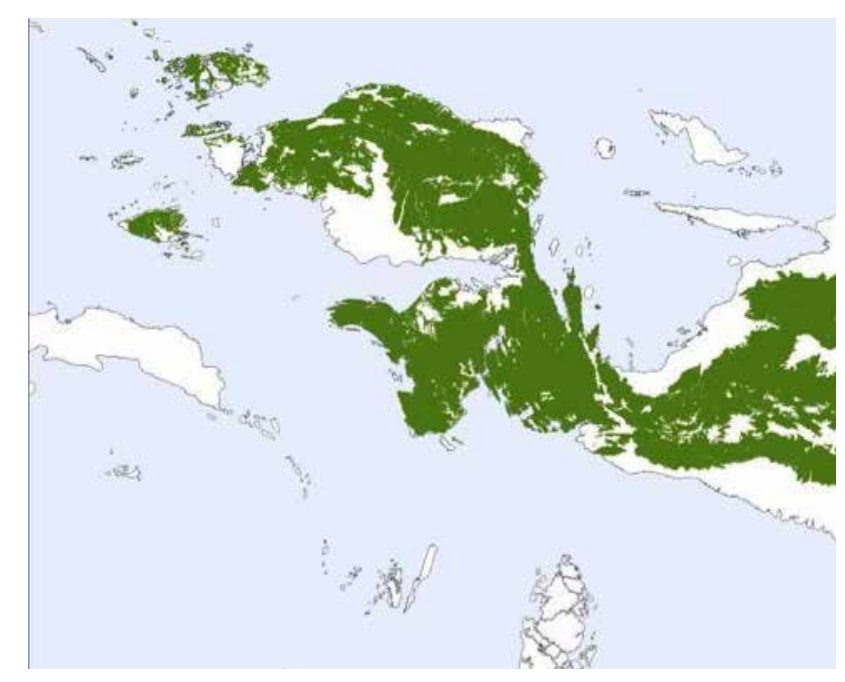

Ministry of Environment map showing 59,800,000 ha of primary forest cover

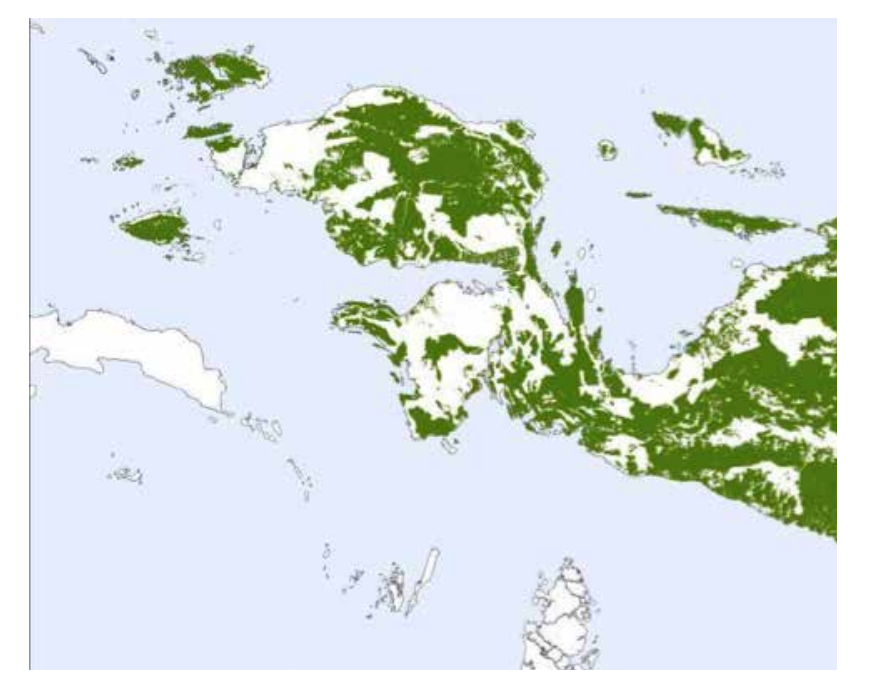

Ministry of Forestry map showing $44,200,000$ ha of primary forest cover

Figure 25. Differences between the 2009 Ministry of Forestry and Ministry of Environment land cover maps of Papua. Source: UKP4 (2012). 
These discrepancies have made it difficult for different government institutions to agree on spatial planning decisions and critical initiatives such as the moratorium on conversion of primary forest and peatland. Moreover, this situation has allowed corrupt practices related to issuing concessions and other licenses to thrive as government officials have been able to manipulate and alter maps to accommodate different interests. Different ministries have traditionally used their own maps for issuing permits to convert peatlands and forests, resulting in poor management, overlapping land claims, and rampant deforestation (Mongabay 2012a). It has also made it difficult to attribute blame for forest clearing, fires or other illegal activities, as overlapping boundaries and differing maps make it hard to identify which stakeholders are active in a particular area.

The One Map initiative is expected to clarify concession boundaries and to help hold companies responsible for their actions (Sizer et al. 2013). In 2010, UKP4 showed President Yudhoyono that forest cover maps from the Ministry of Environment and the Ministry of Forestry were not the same and he instructed that one map be created. On 23 December 2010, President Yudhoyono called a cabinet meeting on measures for emission reduction from deforestation and forest degradation so that "there should be one authoritative map for national reference" ("harus ada satu peta yang menjadi rukukan nasional') (Samadhi 2013). This gave rise to the One Map initiative, which strives to build upon Indonesias national spatial data network to provide better natural resource governance and bureaucratic reform. One Map processes have been designed to create collaboration and trust building among ministries and state agencies. For the first time in Indonesia, it is expected that ministries and state agencies will work together to conceive and update a common map. The key objectives of the One Map initiative are as follows:

- Develop one standard for thematic mapping, which will be approved by the Geospatial Information Agency (Badan Informasi Geospatial).

- Develop a database of spatial and nonspatial information to resolve license overlaps.

- Develop a portal that will archive and display any map produced by national or subnational government institutions (UKP4 2012). The portal is expected to be made public to increase transparency and allow local people and organizations to provide input (Samadhi 2013).
The One Map initiative also strives to incorporate indigenous land rights and to include maps of these lands in the portal. It is therefore hoped that it will develop a single, all-encompassing map of Indonesia that aims to contain all relevant information linked to forest licensing and land use claims.

The initiative is currently being led by UKP4, and the Geospatial Information Agency has been tasked with preparing the system infrastructure and the standardization of the existing maps, including maps of indigenous peoples' territories. This will allow all thematic maps from each sector plus the indigenous maps to be integrated. According to the director of Indonesia's Participatory Mapping Network and the head of Indonesia's Ancestral Domain Registration Agency, 265 maps of indigenous territories, covering 2.4 million ha, were passed on to the Geospatial Information Agency and UKP4 in November 2012 for incorporation into the One Map. The Participatory Mapping Network has also been working with the Geospatial Information Agency to prepare a participative mapping guide so that indigenous territory maps can be made according to a community spatial data standard and further contribute to the One Map. In 2012, UKP4 also commissioned several groups to acquire existing thematic maps and licenses in key REDD+ provinces (East Kalimantan, Central Kalimantan, South Sumatra, Jambi and Central Kalimantan)

The One Map will take considerable time to develop because it will require extensive consultation with provincial and district governments and other stakeholders. It will also need to be continuously reviewed and updated to include new spatial data and inputs from stakeholders. This process will allow different levels of government to harmonize spatial data and to use up-to-date and accurate spatial data for good forest governance and spatial planning.

\section{REDD projects and policies}

Reducing emissions from deforestation and forest degradation, and enhancing forest carbon stocks in developing countries (REDD+) began to emerge in 2005 as a leading mechanism to combat climate change and encourage forest-rich developing countries, such as Indonesia, to curb deforestation (Angelsen 2009).

REDD refers to (1) mechanisms for paying developing countries for reducing emissions from 
deforestation and forest degradation (compared with a reference level) and (2) readiness activities that prepare countries to participate in REDD (Angelsen and Wertz-Kanounnikoff 2008).

REDD has been promoted as a mechanism to generate large, inexpensive and rapid reductions in global GHG emissions. The international community can achieve this by paying forest owners and users - either through national governments or directly - to fell fewer trees and manage their forests better (Angelsen 2009).

REDD has been embraced in Indonesia as one of the most viable means of saving forests from conversion, as it can potentially offset the economic benefits of converting forest land to oil palm, industrial timber or other plantations. Nevertheless, the REDD mechanism is complicated and poorly understood. The international REDD+ architecture is far from clear and will continue to evolve over the next few years. During the UNFCCC 13th Conference of the Parties in Bali in December 2007, it was agreed that Indonesia would embark on a program to test the implementation of REDD. The guiding principle for this process is that all demonstration projects need to examine how the whole REDD supply chain can be implemented under varying spatial, sectoral and administrative conditions.

In order for a REDD scheme to result in payments for carbon units traded, a number of steps must be fulfilled. These steps have been defined as the REDD supply chain and consist of the establishment of a baseline, reductions in carbon emissions achieved against the 'business as usual' scenario, monitoring and verification of reductions, accounting of carbon trading units and distribution of the payments from the market to the agencies responsible for achieving the tradable carbon credits (MoF 2008).

Pilot projects should ideally test how these steps can be undertaken under a range of circumstances to result in tradable carbon credits. The outcome of the demonstration projects should determine where information gaps lie, the practicality of implementing management options at different spatial and administrative scales, the quality and permanence of the carbon credits that can be achieved, and a mechanism for transparent distribution of payments (MoF 2008).

REDD demonstration projects were to be tested at a variety of scales (national, provincial and district) and in different land use areas (protected areas, natural production forests, industrial plantation forests and oil palm plantation areas). Selection of geographical locations was to also allow the testing of circumstances in forests that are on peat soils or mineral soils. Site selection was to consider locations where REDD benefits can contribute to a broad range of social and infrastructure improvements, demonstrating the capacity of the new carbon mechanism to address poverty alleviation and opportunity growth, in return for forest stewardship, not encroachment.

The Bali commitment to experiment with the REDD supply chain has triggered massive expansion in firstgeneration REDD projects in Indonesia. In 2013, approximately 52 REDD demonstration projects had been established. Most REDD+ projects are on the Indonesian part of Borneo (Kalimantan) (21 projects) and Sumatra (6 projects), with only a few each on Java, Lombok and Nusa Tenggara (4), Sulawesi (5) and Papua (6). Project sizes vary from 7000 ha to 2 million ha (Sekala 2013). Several proponents have developed REDD projects where they previously had conservation projects. The activities of these projects range from support of REDD policy development at the national level to large-scale provincial demonstration projects and local capacity-building efforts. Most projects plan to pursue certification or at least claim that they will meet the standards of a voluntary carbon scheme.

The Indonesian government has also pledged to support REDD. A number of laws that will help facilitate REDD have been put in place, including a law for guidance for REDD pilot projects (Ministerial Decree P68/2008), a law that outlines mechanisms for reducing emissions from deforestation and degradation (Ministerial Decree P30/2009), and most recently Ministerial Regulation P20/2012, which sets forth basic principles, criteria for demonstration activities, and rights and obligations of forest carbon implementers.

Nevertheless, progress with REDD has been slow in Indonesia, and several REDD projects have failed or are likely to be discontinued. For instance, one of the largest and best funded (USD 30 million) REDD+ projects, the Kalimantan Forest Carbon Partnership, was discontinued in 2013 because it had failed to secure support from the local government and communities. The Partnership was originally slated to protect 70,000 ha of peat forests, re-flood 200,000 ha of dried peatlands and plant 100 million 
trees, projected to lead to 700 million tonnes of GHG reductions over 30 years (AustraliaIndonesia Partnership 2009). It was championed as an important test case for initiating climate action through the REDD program, but few of its objectives were achieved. The project's termination is a setback for REDD+ in Indonesia as it throws doubt on the overall viability of REDD+.

The development of an institutional framework for REDD is also behind schedule, and major funders, such as Norway, have expressed concern about progress and Indonesia's overall commitment to reducing emissions from deforestation

(Rondonuwu 2012). Some progress was made when the Indonesian president signed a decree to establish the managing agency for the reduction of emissions from deforestation and degradation of forest and peatlands in September 2013 (President of the Republic of Indonesia Decree 62, Year 2013). The REDD+ Managing Agency is tasked with helping the president coordinate, synchronize, plan, facilitate, manage, monitor, oversee and control REDD+ in Indonesia. Among other things, the REDD+ Managing Agency will be responsible for forming and developing a REDD+ national strategy and REDD+ safeguards, coordinating and formulating REDD+ policies, preparing and coordinating instruments and mechanisms of REDD+ funding, managing aid funds, developing standards and methodologies to measure GHG emissions and sequestration from REDD+ programs, increasing capability and capacity to implement REDD+, coordinating law enforcement related to the implementation of REDD+ and monitoring and evaluation. The political process of establishing this agency took more than two years. Despite this long time period, some NGOs consider the regulation to establish the agency to be weak and do not expect it to be able to facilitate REDD+ in Indonesia (Lang 2013c).

The REDD+ concept has also been heavily criticized. Concerns have been raised about the potential for REDD+ projects to restrict the land use rights of local people who depend on forest resources for their livelihoods (Sommerville 2013). REDD+ has also been framed as a mechanism for wealthy nations and corporations to expunge their responsibility for carbon emissions onto developing forest-rich nations such as Indonesia. There are also fears that large volumes of REDD+ carbon credits could flood carbon markets and undermine carbon pricing. REDD+ projects may also clash with the need to allocate productive and fertile land for food crops (Lawlor and Huberman 2008; Ewing 2011). REDD+ has great potential to generate income from the reduction of deforestation, forest degradation and emissions resulting from land use change. However, institutional progress has been slow, criticism has been significant and the failure of large-scale REDD+ projects such as the Kalimantan Forest Carbon Partnership has dampened enthusiasm. Technical capacity to measure and monitor emission reductions is also limited. Significant effort is consequently required to allow this concept to gain credibility, acceptance and success in Indonesia.

\section{National and regional mitigation action plans}

To achieve the ultimate objective of the UNFCCC, parties should protect the climate system for the benefit of present and future generations, on a basis of equity and in accordance with their common but differentiated responsibilities and respective capabilities.

The Bali Action Plan, determined at the 13th Conference of the Parties of the UNFCCC, encouraged developing countries to develop Nationally Appropriate Mitigation Actions to combat humaninduced global warming. These are expected to be the main vehicle for mitigation actions in developing countries under a future climate agreement. They are thought to provide a new opportunity for developing countries to take action on their large and rapidly increasing emissions, while managing their growth, social and development needs.

In 2011, the president of Indonesia issued Presidential Regulation 61/2011 on a National Action Plan for Reducing Greenhouse Gas Emissions. This regulation will provide the basis for various related ministries and institutions as well as the regional governments to implement activities that will directly and indirectly reduce GHG emissions. The regulation reaffirmed the Indonesian government's commitment, made at the Group of Twenty meeting in Pittsburg in September 2009 , to reduce GHG emissions by $26 \%$ by 2020 with national funding and up to $41 \%$ if adequate international support can be made available.

The National Action Plan primarily seeks to design programs and activities that will reduce GHG emissions and serve as guidance on investment 
relating to coordinated GHG emission reduction at national and regional levels. GHG emission reductions are to be achieved through:

- sustainable peatland management

- reductions in the rate of deforestation and land degradation

- development of carbon sequestration projects in forestry and agriculture

- promotion of energy efficiency

- development of alternative and renewable energy sources

- reduction in solid and liquid waste

- shifting to low-emission transportation modes.

As part of the National Action Plan, each province will need to develop a Regional Action Plan on Greenhouse Gas Emissions Reduction. The contributions of local (provincial) governments are expected to include:

- calculation of mitigation potential and construction of a provincial business-as-usual baseline

- development of a strategy for emission reduction

- proposal of local GHG mitigation action

- identification of key stakeholders, institutions and financial resources (Bappenas 2011).

Guidelines on formulating Regional Action Plans were issued in late 2011 (Bappenas 2011). The guidelines stipulated that the plans should continue to prioritize people's welfare to achieve sustainable development and not hinder economic growth and poverty alleviation. The plans were also supposed to be developed in a participatory manner and to be aligned with development plans and spatial plans (Bappenas 2011). The guidelines provided detailed guidance on the required structure and content of the Regional Action Plans and stressed that provinces would need to propose concrete mitigation actions to reduce GHG emissions from existing and new activities (Bappenas 2011).

National and regional action plans are expected to emphasize the reduction of GHG emissions resulting from land use, land use change and forestry. This is because the share of emissions from land-based sectors (including peat fires and agriculture) is approximately $67 \%$ of total national emissions ( $\mathrm{MoE}$ 2010; Figure 26). Land-based emissions primarily result from deforestation, forest and peatland degradation and other land-use activities through burning, decomposition of waste forest matter and soil degradation in cleared land and rice fields and the use of fertilizer and chemicals in agricultural lands.

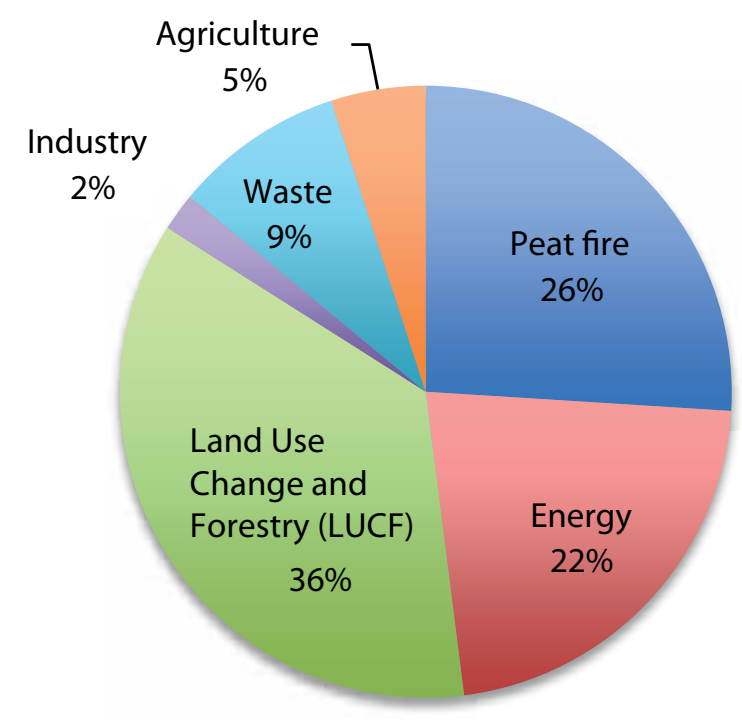

Figure 26. Indonesia's nationwide emissions, 2004. Source: MoE (2010).

Determining a baseline for monitoring the reduction of GHG emissions arising from the land-based sector is difficult and beyond the capacity of many district governments. Rates of deforestation and degradation differ throughout the archipelago, which means that monitoring GHG emission reductions against a subnational baseline would be more accurate. However, it is only possible to factor in leakage if GHG emissions are reduced at a national level. A range of other issues also need to be carefully considered, including the reference period for a historical baseline and the gases that will be measured for the land-based sector (just $\mathrm{CO}_{2}$, or also methane $\left(\mathrm{CH}_{4}\right)$ and nitrous oxide $\left(\mathrm{N}_{2} \mathrm{O}\right)$ (Bappenas and GIZ 2013).

National and regional mitigation action plans on GHG emission reductions are potentially important instruments for reducing deforestation and land degradation. Significant progress has been accomplished to date. All provinces had finalized their regional action plans by January 2014 (Bappenas 2014). A national secretariat for the National Action Plan has also been established to improve the accessibility of information and technical assistance for issues related to the Plan. The secretariat has established a web page (http://www.sekretariatrangrk.org/english/) that provides information on the secretariat and relevant documents. Guidelines on monitoring, evaluation and reporting progress with the mitigation action plans have also been published (Bappenas 2013), and an online system for Regional Action Plan monitoring, evaluation and reporting is being established. 
Nevertheless, both national and regional mitigation action plans are at odds with the current development master plan, which primarily stresses that economic development should be stimulated through the exploitation of natural resources and the establishment of large-scale estate crops in the outer islands. Significant technical capacity will also need to be established in the districts and provinces to ensure that regional mitigation action plans can be implemented, evaluated and reported.

\section{Environmental impact assessments}

According to Law No. 23/1997, all large-scale plantation developments are required to undertake an environmental impact assessment (EIA) before a plantation business permit is allocated (WCS 2010). The EIA is supposed to document the potential impacts on the environment and plans for monitoring and managing those impacts. Government Regulation No. 27/1999 on Environmental Impact Assessment further determines the criteria for significant environmental impacts. Environmental issues to be assessed include physical aspects such as climate, air pollution, soil erosion and hydrological systems; biotic features such as flora and fauna or biodiversity; social aspects such as labor, income, land tenure and control, and regional economy; and cultural impacts such as conflict, social cohesion, customary rights and people's perception of the proposed project. In addition, health aspects should also be assessed. Plantations covering more than 3000 ha are subject to EIAs. Plantations of this size are considered to have significant impacts on soil, water, ecosystems and social conditions.

Investors are required to hold a public hearing on the plantation plan before the EIA is prepared. The public is allowed 30 days for comments and suggestions. Through its regulation, the head of the National Land Agency also stipulated that transfer of land from customary landowners to companies shall be displayed in a written form in front of the head of the local Land Office. However, in practice, local communities often do not have a say in the process. The government agency that is supposed to serve as a neutral facilitator or mediator often sides with the investors (Caroko et al. 2011).

EIAs should be a tool to help decision makers determine whether or not a project should continue. However, permits for large-scale plantations appear to be released without taking into account the requirements of an EIA. The lack of enforcement of EIA policies also creates adverse social impacts, as the law requires companies to empower local people living around the plantation by providing public facilities and educational support. It is speculated that several companies run their operations without approved EIA documents (EIA and Telapak 2012).

The government has gradually tried to improve the governance of EIAs, but the process is widely considered to be outdated, providing minimal protection for the environment or local communities. EIAs have the potential to protect forest and peatland areas with high biodiversity and other environmental benefits, but only if the governance and enforcement of the EIA law can be improved.

\section{Efforts to encourage sustainable biofuel production}

A number of initiatives have been launched to encourage sustainable biofuel and biofuel feedstock production. The most relevant for Indonesian producers are the RSPO, the ISPO Initiative, the RSB and the Better Sugarcane Initiative. Among other things, these initiatives aim to prevent the conversion of areas of high biodiversity or high carbon stock for the production of raw materials for biofuels. The European Commission has endorsed these initiatives, and it requires EU member states to support them. In order to receive government support or count toward mandatory national renewable energy targets, biofuels used in the EU (whether locally produced or imported) have to comply with sustainability criteria outlined in the standards issued by these initiatives (European Commission 2013).

\section{Roundtable on Sustainable Palm Oil}

The RSPO was launched in April 2004 to encourage sustainable oil palm developments that do not result in deforestation or carbon emissions. RSPO is a global, multistakeholder initiative that promotes the production and use of sustainable palm oil products. It includes oil palm growers, banks and investors, manufacturers of consumer goods, social and environmental NGOs, palm oil processors and retailers. By April 2013, RSPO had 828 ordinary members, 100 affiliate members and 297 supply chain associates (RSPO 2014).

The RSPO principles and criteria were originally adopted at the end of 2007. They were reviewed 
after extensive dialogue and consultations among different stakeholders in February 2013. The new criteria address GHG emissions, an issue that was just emerging in 2005, at which time the science of how to address them was lacking. For example, criterion 7.8 calls for new plantation developments to be designed to minimize net GHG emissions. The revised principles and criteria were endorsed by the RSPO executive board in February 2013, and was voted on by the RSPO ordinary membership at an extraordinary General Assembly on April 25, 2013 in Kuala Lumpur. The new principles and criteria can also be seen in Appendix 11.

By 2012, the RSPO had certified 37 companies, which produced around 2.1 million tonnes of palm oil per year and occupied around 427,250 ha of oil palm plantations in Indonesia. Most of these plantations were located in Central Kalimantan, North Sumatra, Riau and South Sumatra (Bisinfocus 2012; Appendix 1). The largest concession to be granted RSPO certification is PT Musim Mas, which is located in Dumai, Riau. Another 27 companies have been assessed and are awaiting certification (Bisinfocus 2012; Appendix 1).

Despite a gradual increase in the area of RSPOcertified $\mathrm{CPO}$ plantations, there is growing concern among some private sector actors and policy makers about the inability of RSPO to reassure the international market that Indonesia is committed to sustainability (Paoli et al. 2010). There has also been increasing criticism by international environmental NGOs concerning violations of RSPO certification standards. RSPO certification is also considered costly, especially for smallholders and small and medium-size companies. These concerns among others have led Indonesian policy makers to establish their own certification scheme. The Indonesian Sustainable Palm Oil (ISPO) scheme has advantages because it is mandatory for all oil palm companies in Indonesia; however, it currently does not match the RSPO criteria when it comes to land use change and community rights.

\section{Indonesian Sustainable Palm Oil}

In March 2011, Ministry of Agriculture Decree No. 19/Permentan/OT.140/3/2011 launched the ISPO standard, which aims to make Indonesian palm oil producers compliant with Indonesian laws and regulations. The standard was implemented in March 2011 on a trial basis and became mandatory for all large-scale oil palm plantation companies operating in Indonesia by the end of 2014 and all smallholder companies by 2015 .
The ISPO standard includes 98 indicators, which elaborate seven principles: (1) the plantation licensing and management system, (2) the application of technical guidelines for oil palm cultivation and processing, (3) environmental management and monitoring, (4) responsibility toward workers, (5) social and community responsibility, (6) empowering the community economy and (7) sustainable business improvement. The new standard also seeks to support Indonesia’s GHG reduction targets.

The ISPO standard was established because industry representatives had become disappointed with the RSPO and its ability to reassure the international market of Indonesia's commitment to sustainable palm oil (Paoli et al. 2010). Industry representatives also felt that the RSPO was dominated by the interests of NGOs and that the interests of consumer countries were prioritized over those of producer countries (Caroko et al. 2011). Several executives from the Indonesian Palm Oil Producers Association (Gabungan Pengusaha Kelapa Sawit Indonesia) and the government-sponsored Indonesian Palm Oil Board have urged local companies to boycott or quit the RSPO, alleging that the organization had departed from its original mission (Jakarta Post 2010). RSPO certification is also considered to be too costly and unrealistic for smallholders and small and medium-size companies (Down to Earth 2011). Certification costs are likely to increase as companies aspiring to RSPO certification will first have to obtain ISPO certification, because Principle 2 of the RSPO standard requires members to comply with applicable laws and regulations in the countries in which they operate (Wilmar 2011). Nevertheless, the ISPO is considered to have weaker standards than the RSPO, as it does not require the recognition of customary rights or of communities' right to give or withhold their free, prior and informed consent to planned oil palm plantations on their lands.

The ISPO standard may encounter difficulties in the international arena as its credibility is likely to be tarnished by Indonesia's governance issues and mounting evidence that oil palm has been planted on peatlands or resulted in forest conversion. ISPO credibility thus depends on the extent to which the new standard can demonstrate reductions in GHG emissions and the use of peatlands or carbon-rich forests (Caroko et al. 2011). 
Currently nine companies ${ }^{20}$ are registered with the ISPO, which is able to audit oil palm companies and recommend if they are eligible for ISPO certification to the ISPO committee. The latest data suggest that as of January 2014, 40 companies covering 378,000 ha of planted oil palm have already received ISPO certification (ISPO 2014). Most of these companies operate in Riau, South Kalimantan, Central Kalimantan and Jambi. The ISPO website also announces that around 127 companies are currently under assessment. Cooperation with the $\mathrm{RSPO}$ is also being encouraged, as both parties agreed to conduct a joint study on the key differences and similarities between the ISPO and the RSPO. This study will be funded by the United Nations Development Programme (UNDP) and it is expected to create a strategic alignment of efforts by the Indonesian government and the RSPO in creating a more environmentally and socially responsible palm oil sector in Indonesia.

The ISPO is mandatory and consequently has great potential to influence the Indonesian oil palm sector. While its principles and criteria primarily require oil palm companies to comply with Indonesian law and are considered to be weaker than the RPSO's, its standards are likely to improve if cooperation with the RSPO can be enhanced.

\section{Roundtable on Sustainable Biomaterials}

The RSB is an international initiative that brings together farmers, companies, NGOs, experts, governments and intergovernmental agencies concerned with ensuring the sustainability of biofuel production and processing. The RSB was established in 2007 to provide and promote a global standard of socially, environmentally and economically sustainable production of biofuels and conversion of biomass. It also seeks to provide a global platform for multistakeholder dialogue and consensus building and ensure that users and producers have access to credible, practical and affordable certification.

The RSB has facilitated multistakeholder consultations to develop principles and criteria for sustainable biofuel production. These principles and criteria will continuously be discussed, debated and updated to keep up with advancements in

20 These are PT Mutuagung Lestari, PT TUV Nord Indonesia, PT Sucofindo (Persero), PT TUV Rheinland Indonesia, PT SAI Global Indonesia, PT Mutu Hijau Indonesia, PT SGS Indonesia, PT BSI Group Indonesia and PT LRQA Indonesia. the biofuel sector. RSB principles address legality; planning, monitoring and continuous improvement of operations; GHG emissions; human and labor rights; rural and social development; local food security; conservation; soil, water and air quality; use of technology and inputs; management of waste; and land rights.

The standards require biofuel producers to consider the entire life cycle of their crops, including plans for water management and the preservation of highconservation-value land through the establishment of buffer zones. Soil health would be maintained or enhanced and air pollution minimized. GHG emissions from biofuels production must be reduced over time, according to the guidelines.

The standards also include a number of social provisions. Local communities or indigenous groups should have given their consent for biofuel developments and be fairly compensated for transferring land rights. Slave labor and child labor are banned. The standards also emphasize the use of marginal, degraded or previously cleared land for growing biofuels.

Principle 3 of the RSB standard addresses climate change and seeks to ensure that biofuels significantly reduce life-cycle GHG emissions. It requires companies seeking to gain RSB certification to meet $\mathrm{GHG}$ reduction requirements across their commodity life cycle and to use the RSB lifecycle GHG emission calculation method, which incorporates methodological elements and input data from authoritative sources, is based on sound and accepted science, is updated periodically as new data become available, has system boundaries from well to wheel, includes GHG emissions from land use change (including, but not limited to above- and belowground carbon stock changes) and incentivizes the use of co-products, residues and waste in such a way that the life-cycle GHG emissions of the biofuel are reduced. The criteria under this principle also require biofuel blends to have on average $50 \%$ lower life-cycle GHG emissions relative to the fossil fuels baseline.

The RSB seeks to be an operational certification standard; it began to issue its first compliance certificates in 2011. As of May 2013, only seven certificates had been issued to biofuel and feedstock producers in Australia, Peru, Mexico, the US, Sierra Leone and the Netherlands. No certificates had been issued for Indonesia. These companies were primarily producing ethanol (from waste starch, wheat 
processing and sugarcane) and biodiesel (from used cooking oil). Some analysts have argued that the RSB standards are too high and may therefore prevent any meaningful advances. Others are concerned that the standards will serve as trade barriers and keep developing countries from profiting from a commodity (Block 2010). It is also possible that the RSB can provide guidance and certification to Indonesian producers of biofuel, particularly those that wish to export it to Europe or the US.

\section{Better Sugarcane Initiative}

The Better Sugarcane Initiative is a collaboration of sugar retailers, investors, traders, producers and NGOs who are committed to sustainable sugar production. It seeks to establish principles and criteria that will improve the social, environmental and economic sustainability of sugarcane production.

The Better Sugarcane Initiative submitted an application to the EU for a certification system that includes its core standard, to be recognized as a voluntary scheme. The certification system consists of:

- a production standard, which contains principles and criteria for achieving sustainable production of sugarcane and sugarcane-derived products in respect of economic, social and environmental aspects

- a chain-of-custody standard, which contains technical and administrative requirements to enable the tracking of claims through conversion, processing, manufacturing, transformation, trade and use of all sugarcane-derived products

- audit guidance for members and auditors on how to become compliant with the production and chain-of-custody standards

- a certification protocol, which lists the process and procedures for Better Sugarcane Initiative certification.

The Better Sugarcane Initiative has pledged to focus on the most significant social and environmental issues, such as soil productivity, rational water use, effluent management, biodiversity maintenance and equitable labor relations. It will also enable sugarcane buyers to purchase sugar that has been produced according to agreed, transparent and verifiable criteria.

\section{Sustainability criteria in other countries}

As mentioned earlier, a number of countries are beginning to restrict imports of biofuel to encourage more sustainable biofuel feedstock production. The
European Commission's Renewable Energy Directive mandates that only biofuels that reduce GHG emissions by $35 \%$ compared with petroleum use (with an emissions saving of at least 50\% starting January 2017 and 60\% starting January 2018) are acceptable. The US Renewable Fuel Standard and the US Clean Air Act also require producers to meet a minimum $20 \%$ reduction threshold in GHG emissions.

These new policies may encourage Indonesian producers to improve biofuel production standards and ensure that biofuel feedstocks do not replace forest, peatlands or other lands containing high carbon stocks or high conservation values. However, such policies may also encourage biofuel producers in Indonesia to find alternative and less restrictive markets in other importing countries, such as Korea, China, India or Brazil.

\section{Summary}

Several measures are being undertaken, both domestically and internationally, to improve the sustainability and credibility of agricultural production in Indonesia. Within Indonesia, the government is attempting to improve spatial planning processes and is reviewing the allocation of oil palm permits in several forest-rich provinces, including Central Kalimantan, East Kalimantan, Riau, Jambi and South Sumatra. This will help to ensure that land is allocated for real oil palm or other feedstock plantations rather than for timber extraction. The government has also expressed interest in utilizing degraded land for biofuel feedstock production, and several initiatives, such as the Palm Oil, Timber, Carbon Offset Initiative, are providing information on degraded land and facilitating land swaps that will allow companies allocated forest or peatland for plantation developments to secure degraded land instead.

A moratorium on converting primary forest and peatland was issued in May 2011 and extended for two years in May 2013. This moratorium will help to ensure that forests and peatlands with high biomass values will not be allocated for land use change. The One Map and REDD initiatives are also helping Indonesia to improve spatial data and to develop mechanisms for reducing GHG emissions and allowing projects to be developed that promote sustainable biofuel production. National and regional mitigation action plans on GHG emission reductions have the potential to guide low-emission development and reduce GHG emissions from land use change. 
Indonesia's environmental impact assessment law (No. 23/1997) also has the potential to promote sustainable biofuel production, as it requires plantations covering more than 3000 ha to carry out an assessment of the potential impacts of the plantation on the environment. This regulation is weakly enforced but can potentially be mobilized to promote more sustainable practices. The Indonesian government also launched the mandatory ISPO initiative to promote sustainable oil palm production and ensure compliance with Indonesian laws and regulations.

On the international front, several standards have been developed to encourage sustainable feedstock production. These include the RSPO and RSB standards. These standards now seek to reduce GHG emissions and only grant companies certification and endorsement if they can demonstrate that they are not planting biofuel feedstocks on forested land or peatland.
Several countries have also placed restrictions on biofuel imports originating in Indonesia to promote more sustainable biofuel production. For instance, the EU mandates that only biofuels that reduce GHG emissions by 35\% compared with petroleum use are acceptable, and the US requires producers to meet a minimum $20 \%$ reduction threshold in GHG emissions. Germany is in the forefront of these developments. In 2014 it introduced a regulation under which biofuel duties are measured in net GHG savings. The fuel having the best GHG savings will get the highest prices.

These new policies may encourage Indonesian producers to improve biofuel production standards and ensure that biofuel feedstocks do not replace forest, peatlands or other lands containing high carbon stocks or high conservation values. However, such policies may also encourage biofuel producers in Indonesia to find alternative and less restrictive markets in other importing countries. 


\section{Conclusion}

Despite the recent global recession, Indonesia has experienced relatively strong economic performance, with an average GDP growth rate of just below $7 \%$ per year over the past 10 years. Population has increased by about $1.5 \%$ per year, from $205,843,000$ to $241,134,000$ between 2000 and 2011. Today, Indonesia is the fourth most populous country in the world (behind China, India and the US) and the most populous country in Southeast Asia. Strong economic growth and an expanding population have created increasing pressure on Indonesia's forests and increasing demand for energy.

Indonesia's forests are rich and biodiverse and provide a range of valued products for local communities and world consumers. They also play a critical role in climate change as they store carbon and release $\mathrm{CO}_{2}$ into the atmosphere when they are destroyed. Indonesia has had one of the highest rates of deforestation in the world over the past 30 years. Ministry of Forestry statistics indicate that 99.5 million ha of forest remained in Indonesia in 2011, down from around 159 million ha in 1950. Around 46\% (46.4 million ha) of these forests are primary forests and $49 \%$ (48.7 million ha) secondary forests. The remaining 5\% (4.4 million ha) are classified as plantation forest.

Indonesia's forests have long been harvested by local people to meet their daily needs. Largescale extraction of forests began after the Dutch colonized the Indonesian archipelago and accelerated after Indonesia embarked upon a process of large-scale extraction from the outer islands (primarily Sumatra and Kalimantan) in the early 1970s. Timber extraction began with largescale logging to generate export revenue, but it later fed Indonesia's growing timber processing industry, which has focused on the production of pulp, paper and plywood. The expansion of these industries since then has created a level of demand that cannot be met by any sustainable forest management system and has resulted in natural forest loss via logging and clear felling.

Timber extraction and large-scale plantations have played a dominant role on the islands of Sumatra and Kalimantan and are now moving to the island of Papua. Forest is being replaced by numerous land uses, with oil palm and industrial timber plantations dominant. The oil palm and industrial timber sectors have experienced substantial growth on the outer islands since 1990. Area expansion has been most significant for industrial timber plantations, as planted area has expanded by $179 \%$ per year from just 131,655 ha in 1990 to 4.96 million ha in 2011 . However, the largest area of land (8.9 million ha) has been dedicated to oil palm, which has expanded by around $28 \%$ per year from 1.3 million ha in 1990 to 8.9 million ha in 2011. Both of these sectors are concentrated in Kalimantan (primarily Central Kalimantan) and Sumatra (primarily Riau), where most deforestation has also occurred over the past two decades. Oil palm plantations are expanding by around 400,000 ha per year, and industrial timber plantations by around 300,000 ha per year.

Both oil palm and industrial timber have conferred important economic benefits for Indonesia. The oil palm sector generated export earnings valued at USD 13.46 billion in 2010 (around $2.5 \%$ of GDP), and the pulp and paper industry contributed around $1.2 \%$ of GDP in 2010. The oil palm sector was estimated to employ 2.9 million people and the pulp and paper sector around 1.7 million people.

Expansion of oil palm and industrial timber plantations has also been stimulated by recent interest in bioenergy, which has been promoted since the Indonesian government pledged to reduce dependency on fossil fuels by $10 \%$ for 2010 and $25 \%$ by 2025 . Indonesia became the sixth largest producer of biodiesel in 2011, and it has increased production from 64,000 metric tonnes in 2006 to 1.76 million metric tonnes in 2012. Around $7 \%$ of Indonesia's total CPO production for 2011 (1.76 million metric tonnes) was used to produce biodiesel, and $5.5 \%$ of Indonesia's total planted oil palm area (494,744 ha) was used to produce biodiesel. Palm-oil-based biodiesel is likely to be absorbed by the domestic market because of the Indonesian government mandated fuel blending targets. Wood pellet production may also experience some growth in Asian markets such as Korea, Japan and China. However, other crops promoted for 
bioenergy development (such as jatropha, cassava and sugarcane) are not experiencing growth and are therefore not likely to have a significant impact on land cover change over the next decade.

The relationship between plantation expansion and land cover change is extremely complex, but it is generally thought that the expansion of oil palm and industrial timber plantations has been a primary driver of deforestation over the past decade. This trend is expected to continue as available spatial data indicate that 6.78 million ha of forested land and 1.98 million ha of peatland have been allocated to oil palm and industrial timber plantations in principle.

A total of 35.9 million ha of land, 19\% of Indonesia's total land area, has been allocated to oil palm and industrial timber plantations. The destruction of Indonesia's forests and carbon-rich peat soils is expected to lead to significant carbon emissions.

Policy measures at both national and international levels are being taken to improve the performance of these two sectors and ensure that bioenergy produced from oil palm and industrial timber plantations does not increase GHG emissions. Within Indonesia, the government has pledged to reduce GHG emissions by $26 \%$ by 2020 with national funding and up to $41 \%$ if adequate international support can be made available. National and regional mitigation action plans have been developed in 31 of Indonesia's 33 provinces to reduce GHG emissions. These plans place significant emphasis on reducing GHG emissions through sustainable peatland management, reducing the rate of deforestation and land degradation and developing carbon sequestration projects in forestry and agriculture. This is because the share of emissions from land-based sectors (including peat fires and agriculture) is approximately $67 \%$ of total national emissions. In Indonesia, land-based emissions primarily result from deforestation, forest and peatland degradation and other land use activities.

The Indonesian government is also attempting to improve spatial planning processes and is currently reviewing the allocation of oil palm permits in several forest-rich provinces, including Central Kalimantan, East Kalimantan, Riau, Jambi and South Sumatra. This will help to ensure that suitable land is allocated for real oil palm or other feedstock plantations rather than for timber extraction. The government has expressed interest in utilizing degraded land for biofuel feedstock production, and several initiatives, such as the Palm Oil, Timber, Carbon Offset Initiative, are providing information on degraded land and facilitating land swaps that will allow companies allocated forest or peatland for plantation developments to secure degraded land instead. A moratorium on converting primary forest and peatland was issued in May 2011 and extended for two years in May 2013. This moratorium will help to ensure that forests and peatlands with high biomass values can be re-evaluated and not allocated for biofuel feedstock crops. The One Map initiative is assisting this process by reviewing and harmonizing spatial data so that they are consistent, up-to-date and accurate and can be used for effective decision making. The REDD initiative is also helping Indonesia to develop mechanisms for reducing GHG emissions and allowing projects to be developed that promote sustainable biofuel production.

Indonesia's environmental impact assessment law (No. 23/1997) also has the potential to promote sustainable agricultural production as it requires plantations covering more than 3000 ha to carry out an assessment of their potential impacts on the environment. This regulation is weakly enforced but can potentially be mobilized to promote more sustainable practices. The Indonesian government has also launched the mandatory IPSO initiative to promote sustainable oil palm production and ensure compliance with Indonesian laws and regulations.

On the international front, several standards have been developed to encourage sustainable feedstock production. These include the RSPO and RSB standards. These standards seek to reduce GHG emissions and only allow companies to seek certification and endorsement if they can demonstrate that they are not planting biofuel feedstocks on forested land or peatland.

Several countries have also placed restrictions on biofuel imports originating from Indonesia to promote more sustainable biofuel production. For instance, the EU mandates that only biofuels that reduce GHG emissions by $35 \%$ compared with petroleum use are acceptable, and the US requires producers to meet a minimum $20 \%$ reduction threshold in GHG emissions.

These new policies may encourage Indonesian producers to improve agricultural production standards and ensure that large-scale plantations do not replace forest, peatlands or other lands containing high carbon stocks or high conservation values. However, such policies may also encourage producers in Indonesia to find alternative and less restrictive 
markets in other importing countries. Indonesia's growing CPO-based biodiesel market will also need to be closely monitored to ensure that biodiesel production from oil palm plantations is grown on degraded lands rather than forested land or peatland. There are several ways in which land-based carbon emissions from agriculture in Indonesia may play out in the medium and long term. It is clear that agriculture is an important part of Indonesia's economy, as a driver of infrastructure development and job creation in rural parts of the country. The National Long Term Development Plan 2005-2025 largely relies for growth on the natural resource sectors; it shows greater diversification only in the closing quarter of the period. It is therefore likely that demand for land for commercial commodities such as oil palm and extractive activities for energy (e.g. coal) will remain high. It appears the government may pursue a double path of continuing extensification hemmed in by a continued moratorium on deforestation and emphasis on compliance with specific certification systems. A parallel, but complementary, path may include an increased emphasis on improving the productivity of current and future plantation estates, both large and small.

The exact outcome of current and planned government regulations and private-sector initiatives is difficult to predict with any degree of precision. It very much depends on the political orientation of the new government in Indonesia and market conditions affecting the private sector. 


\section{References}

[ABC] Australian Broadcasting Corporation. 2002. The timber mafia. Four Corners. http://www. abc.net.au/4corners/content/2002/timber_ mafia/resources/resources_indonesia.htm

Abdi A and Slette J. 2012. Indonesia: Biofuels Annual 2012. Gain Report ID1222. Washington, DC: USDA Foreign Agricultural Service, Global Agricultural Information Network.

Adhiati M and Bobsien A. 2001. Indonesia's Transmigration Programme. Report prepared for Down to Earth. http://www.downtoearthindonesia.org/old-site/ctrans.htm

AgroAsia. 2011. South Korean firms develop wood pellet industry in Indonesia. http:// www.agroasianews.com/commodities/ others/11/07/07/south-korean-firms-developwood-pellet-industry-indonesia

Agus F, Handayani E, van Noordwijk M, Idris $\mathrm{K}$ and Sabiham S. 2010. Root respiration interferes with peat $\mathrm{CO}_{2}$ emission measurement. In 19th World Congress of Soil Science, Soil Solutions for a Changing World, Brisbane, Australia. 50-53.

Ali M, Taylor D and Inubushi K. 2006. Effects of environmental variations on $\mathrm{CO} 2$ flux from a tropical peatland in eastern Sumatra. Wetlands 26(2):612-18.

Alvarez P, Burken J, Coan J, Oliveira M, Dominguez-Fauz R, Gomez D, Jaffe A, Medlock K, Powers S, Soligo R and Smulcer L. 2010. Fundamentals of a Sustainable U.S. Biofuels Policy. Paper prepared by the Energy Forum of the James A. Baker III Institute for Public Policy of Rice University, Houston, TX, and Rice University's Department of Civil and Environmental Engineering.

Angelsen A and Wertz-Kanounnikoff S. 2008. What are the key design issues for REDD and the criteria for assessing options? In Angelsen A, ed. Moving Ahead with REDD: Issues, Options and Implications. Bogor, Indonesia: Center for International Forestry Research. 11-22.

Angelsen A. 2009. Realising REDD+: National Strategy and Policy Options. Bogor, Indonesia: Center for International Forestry Research.

Angelsen A. 2008. Moving Ahead with REDD: Issues, Options and Implications. Bogor, Indonesia: Center for International Forestry Research.
Antara News. 10 April 2013. APP dapat pinjaman 1,8 miliar dolar AS. Jakarta: Antara. www. antaranews.com/print/398730/app-dapatpinjaman-18-miliar-dolar-as

Antara News. 22 October 2005. KPK investigates 1 million ha plantation project in E. Kalimantan. Jakarta: Antara.

Atabani AE, Silitonga AS, Badruddin IA, Mahlia TMI, Masjuki HH, Mekhile S. 2012. A comprehensive review on biodiesel as an alternative energy resource and its characteristics. Renewable and Sustainable Energy Reviews 16:2070-93.

Austin K, Sheppard S and Stolle F. 2012. Indonesia's Moratorium on New Forest Concessions: Key Findings and Next Steps. Working Paper. Washington, DC: World Resources Institute.

Australia-Indonesia Partnership. 2009. Kalimantan Forests and Climate Partnership Design Document. Jakarta: Australia-Indonesia Partnership.

Awas MIFEE. 2013. Changes to the Moratorium Map and Medco's Sugar Plans. Tracking the Merauke Integrated Food and Energy Estate. https://awasmifee. potager.org/?p=456

Bahana. 2007. Indonesian Plantation Sector: Palm Oil in the Spotlight. Bahana Securities.

Bailey R. 2013. The Trouble with Biofuels: Costs and Consequences of Expanding Biofuel Use in the United Kingdom. London: Chatham House.

Bailis R and Baka J. 2010. Greenhouse gas emissions and land use change from jatropha curcasbased jet fuel in Brazil. Environmental Science Technology 44(22):8684-91.

Bappenas. 2014. Potret Rencana Aksi Daerah Penurunan Emisi Gas Rumah Kaca (RAD-GRK). Jakarta: Ministry of National Development Planning, National Development Planning Agency (Bappenas).

Bappenas. 2013. Pedoman Umum Pemantauan, Evaluasi dan Pelaporan Pelaksanaan RAN-GRK dan RAD-GRK, Kementerian Perencanaan Pembangunan Nasional/Badan Perencanaan Pembangunan Nasional. Jakarta: Ministry of National Development Planning, National Development Planning Agency (Bappenas).

Bappenas. 2011. Guideline for Developing Local Action Plan for Greenhouse Gas Emissions Reduction (RAD-GRK). Jakarta: Ministry of 
National Development Planning, National Development Planning Agency (Bappenas).

Bappenas and GIZ [German Federal Enterprise for International Cooperation]. 2013. Development of the Indonesian NAMAs Framework. Jakarta: Bappenas and GIZ.

Barber C, Matthews E, Brown D, Brown T, Curran L and Plume C. 2002. State of the Forest: Indonesia. Washington, DC: World Resources Institute.

Barber C and Schweithelm J. 2000. Trial by Fire: Forest Fires and Forestry Policy in Indonesia's Era of Crisis. Washington, DC: World Resources Institute.

Barlow C, Zen Z and Gondowarsito R. 2003. The Indonesian oil palm industry. Oil Palm Industry Economic Journal 3:8-15.

Barr C. 2007. Managed Forest Plantations in Indonesia: Recent Trends and Current Plans. Presentation provided at the Meeting of the Forest Dialogue, Pekanbaru, Indonesia, 7-8 March 2007.

Barr C. 2000. Profits on Paper: The Political-Economy of Fiber, Finance, and Debt in Indonesia's Pulp and Paper Industries. Bogor, Indonesia: Center for International Forestry Research.

Barr C, Dermawan A, Purnomo H and Komarudin H. 2010. Financial Governance and Indonesia's Reforestation Fund during the Suharto and Post Soeharto Periods 1989-2009: A Political Economic Analysis of Lessons for REDD+. Occasional Paper 52. Bogor, Indonesia: Center for International Forestry Research.

Barr C, Wollenberg E, Limberg GAN, Iwan R, Sudana M, Moeliono M and Djogo T. 2001. The Impacts of Decentralisation on Forests and ForestDependent Communities in Malinau District, East Kalimantan. Bogor, Indonesia: Center for International Forestry Research. BBC. 22 June 2013. Indonesia fuel prices rocket by $44 \%$ sparking protests. http://www.bbc.co.uk/news/ world-asia-23015511

Besalicto Benget. 12 October 2009. Medco plans wood pellet production. Jakarta Post.

Bisinfocus. 2012. Prospek Perkebunan and Industri Minyak Sawit di Indonesia 2012-2025, edisi keempat. Jakarta: Business Information Focusa.

Bisinfocus. 2006. Prospek Perkebunan and Industri Minyak Sawit Di Indonesia 2006-2020. Jakarta: PT Bisinfocus Data Pratama.

Bisnis Indonesia. 2011. Konglomerat kembangkan investasi HTI di Kalimantan dan Papua. 24 April 2011.

Block B. 2010. Roundtable Reveals International Biofuels Standards. Washington, DC: Worldwatch Institute.
Boediwardhana W. 15 March 2010. East Java needs 48,000 tons of jatropha. Jakarta Post.

Boehm H, Siegert F, Rieley J, Page S, Jauhiainen J, Vasander H and Jaya A. 2001. Impacts and Carbon Release on Tropical Peatlands in Central Kalimantan, Indonesia. Paper presented at the 22nd Asian Conference on Remote Sensing, 5-9 November 2001, Singapore.

BPS. 2012. Statistik Indonesia 2012. Jakarta: Badan Pusat Statistik.

Brockhaus M, Obidzinski K, Dermawan A, Laumonier L and Luttrell, C. 2012. An overview of forest and land allocation policies in Indonesia: Is the current framework sufficient to meet the needs of REDD+? Forest Policy and Economics 18:30-37.

Broich M, Hansen MC, Potapov P, Adusei B, Lindquist E and Stehman SV. 2011. Timeseries analysis of multi-resolution optical imagery for quantifying forest cover loss in Sumatra and Kalimantan, Indonesia. International Journal of Applied Earth Observation and Geoinformation 13(2): 277-291.

Bromokusumo A. 2007. Indonesia: Biofuels Annual 2007. GAIN Report. Washington, DC: USDA Foreign Agricultural Services, Global Agricultural Information Network.

Brown S, Gillespie AJR and Lugo AE. 1989. Biomass estimation methods for tropical forests with applications to forest inventory data. Forest Science 35(4):881-902.

Budidarsono S, Rahmanulloh A and Sofiyuddin M. 2012. Economics Assessment of Palm Oil Production. Technical Brief 26: Palm Oil Series. Bogor, Indonesia: World Agroforestry Center (ICRAF).

Burgess R, Hansen M, Olken B, Potapov P and Sieber S. 2012. The political economy of deforestation in the tropics. Quarterly Journal of Economics 127(4):1707-54.

Byron Y. 1993. Forestry Policies of Selected Countries in Asia and the Pacific. FAO Forestry Paper 115. Rome: Food and Agriculture Organization.

Cahyat A. 19 September 2013. Capturing methane for electricity generation. Jakarta Post.

Caroko W, Komarudin H, Obidzinski K and Gunarso P. 2011. Policy and Institutional Frameworks for the Development of Palm OilBased Biodiesel in Indonesia. Working Paper 62. Bogor, Indonesia: Center for International Forestry Research. 
Casson A. 2001. Decentralisation of Policy Making and Administration of Polices Affecting Forests and Estate Crops in Kotawaringin Timur District, Central Kalimantan. Bogor, Indonesia: Center for International Forestry Research.

Casson A. 1999. The Hesitant Boom: Indonesia's Oil Palm Sub-sector in an Era of Economic Crisis and Political Change. Bogor, Indonesia: Center for International Forestry Research.

Casson A and Obidzinski K. 2002. From New Order to regional autonomy: Shifting dynamics of 'illegal' logging in Kalimantan, Indonesia. World Development 30:2133-2215.

Casson A, Setyarso A, Boccucci M and Brown D. 2007a. A Multistakeholder Action Plan to Curb Illegal Logging and Improve Law Enforcement in Indonesia. Jakarta: World Bank.

Casson A, Tacconi L and Deddy K. 2007b. Strategies to Reduce Carbon Emissions from the Oil Palm Sector in Indonesia. Paper produced for the Indonesian Forest Climate Alliance, Jakarta.

Charles C, Gerasimchuk I, Bridle R, Moerenhout T, Asmelash E and Loan T. 2013. Biofuels - At What Cost?: A Review of Costs and Benefits of EU Biofuel Policies. Manitoba, Canada: International Institute for Sustainable Development.

Chave J, Andalo C, Brown S, Cairns M, Chambers J, Eamus D, Folster H, Fromard F, Higuchi N, Kira T, Lescure J, Nelson B, Ogawa H, Puig H, Riera B and Yamakura T. 2005. Tree allometry and improved estimation of carbon stocks and balance in tropical forest. Oecologia 145:87-89.

Cheng Hai T. 2002. The Palm Oil Industry in Malaysia: From Seed to Frying Pan. Gland, Switzerland: World Wildlife Fund.

Cochrane J. 2 May 2013. Indonesia struggles to end fuel subsidies. New York Times.

Coordinating Ministry for Economic Affairs. 2011. Masterplan for Acceleration and Expansion of Indonesia's Economic Development 2011-2025. Jakarta: The Coordinating Ministry for Economic Affairs.

Curran L, Trigg S, McDonald A, Astiani D, Hardiono Y, Siregar P, Caniago I and Kasischke E. 2004. Lowland forest loss in protected areas of Indonesian Borneo. Science 203:1000-1003.

Dauvergne P. 2004. The politics of deforestation in Indonesia. Pacific Affairs 66(4):497-518.

Dauvergne P. 1998. The political economy of Indonesia’s 1997 forest fire. Australian Journal of International Affairs 52(1):13-17.

Dauvergne P. 1997. Shadows in the Forest: Japan and the Politics of Timber in Southeast Asia. Cambridge, MA: MIT Press.
DeFries R, Rudel T, Uriarte M and Hansen M. 2010. Deforestation driven by urban population growth and agricultural trade in the twenty-first century. Nature Geoscience 3:178-81.

Deparine S. 2009. Indonesia, South Korea collaborates on wood biomass energy. BiofuelsHub. www.biofuelshub.com/component/ content/article/1-news/987-indonesia-southkorea-collaborates-on-wood-biomass-energy

Dermawan A, Obidzinski K and Komarudin H. 2012. Withering before Full Bloom? Bioenergy in Southeast Asia. Working Paper 94. Bogor, Indonesia: Center for International Forestry Research.

Dillon S, Laan T and Dillon H. 2008. Biofuels - At What Cost?: Government Support for Ethanol and Biodiesel in Indonesia. Geneva: Global Subsidies Initiative, International Institute for Sustainable Development.

Directorate General of Estates. 2012. Sugar Cane. Tree Crop Estates of Indonesia. Jakarta: The Ministry of Agriculture.

Doos B. 2002. Population growth and loss of arable land. Global Environmental Change 12:303-311.

Down to Earth. 2011. 100 Years of Oil Palm. Colchester, UK: Down to Earth. http://www. downtoearth-indonesia.org/story/100-yearsoil-palm

EcoEmerald. 2012. Eco-Carbone's jatropha project in Papua, Indonesia http://www.eco-carbone.com/ eco-carbone.php?Firstlevel_ID=4\&Secondlevel_ ID=22\&lang=en

[EIA] Environmental Investigation Agency and Telapak. 2012. Testing the Law: Carbon, Crime and Impunity in Indonesia's Plantation Sector. Jakarta and London: EIA and Telapak.

[EIA] Environmental Investigation Agency and Telapak. 1999. The Final Cut: 'Illegal Logging' in Indonesia's Orangutan Parks. London and Jakarta: EIA and Telapak.

Ekadinata A, Rahmanulloh A, Pambudhi F, Ibrahin I, van Noordwijk M, Sofiyuddin M, Sardjono MA, Rahayu S, Dewi S, Budidarsono $S$ and Said Z. 2010. Carbon Emissions from Land Use, Land Use Change and Forestry (LULUCF) in Berau District East Kalimantan, Indonesia. Bogor, Indonesia: World Agroforestry Centre (ICRAF).

Ekadinata A, Widayati A, Dewi S, Rahman S and van Noordwijk M. 2011. Indonesia's Land-Use and Land-Cover Changes and Their Trajectories (1990, 2000 and 2005). ALLREDDI Brief 01. Bogor Indonesia: World Agroforestry Center.

[Environmental Protection Agency] EPA. 2011. Regulatory Announcement: EPA Issues Notice of 
Data Availability Concerning Renewable Fuels Produced from Palm Oil Under the RFS Program. Washington, DC: United States Environmental Protection Agency.

European Commission, 2013. Renewable energy: Biofuels-Sustainability schemes. http://ec.europa. eu/energy/renewables/biofuels/sustainability_ schemes_en.htm

[European Union] EU. 2011. Fuel Quality Directive Impact Assessment. Brussels: Department for Transport.

Evans P. 2013. Wood based biomass blossoming in Asia. Renewable Energy World Magazine. http:// www.renewableenergyworld.com/rea/u/ Piers_Evans

Ewing JJ. 2011. Forests, Food and Fuel: REDD+ and Indonesia's Land Conundrum. Asia Security Initiative Policy Series Working Paper 19. Singapore: RSIS Centre for Non-Traditional Security (NTS) Studies.

[FAO] Food and Agriculture Organization. 2010. Global Forest Resources Assessment 2010. Rome: FAO.

[FAO] Food and Agriculture Organization. 1998. Indonesia's Sugar Industry, Proceedings of the Fijil FAO 1997 Asia Pacific Sugar Conference. Rome: FAO.

Forest Energy Monitor [FEM]. 2013. http://www. hawkinswright.com/Bioenergy

Forest Energy Monitor [FEM]. 2012. Biomass and pellets: Markets - investments - legislation. http://www.hawkinswright.com/Bioenergy

FFP and SawitWatch. 2006. Ghosts on Our Own Land: Indonesian Oil Palm Smallholders and the Roundtable on Sustainable Palm Oil. Moretonin-Marsh, United Kingdom: Forest Peoples Programme and Perkumpulan SawitWatch.

Furukawa Y, Inubushi, K, Ali M, Itang AM and Tsuruta H. 2005. Effect of changing groundwater levels caused by land-use changes on greenhouse gas fluxes from tropical peat lands. Nutrient Cycling in Agroecosystems 71:81-91.

Forest Watch Indonesia [FWI] and Global Forest Watch [GFW]. 2002. The State of the Forest: Indonesia. Bogor, Indonesia, and Washington, DC: Forest Watch Indonesia and Global Forest Watch.

Gao Y, Skutsch M, Masera O and Pacheco P. 2011. A Global Analysis of Deforestation Due to Biofuel Development. Working Paper 68. Bogor, Indonesia: Center for International Forestry Research.
Geertz C. 1963. Agricultural Involution: The Process of Ecological Change in Indonesia. Berkeley: University of California Press.

Gibbs H, Brown S, Niles J and Foley J. 2007. Monitoring and estimating tropical forest carbon stocks: Making REDD a reality. Environmental Research Letters 2(4). http:// iopscience.iop.org/1748-9326/2/4/045023/ fulltext/

Ginoga K, Cacho O, Erwidodo LM and Djaenudin D. 2002. Economic Performance of Common Agroforestry Systems in Southern Sumatra: Implications for Carbon Sequestration Services. Working Paper CC03, ACIAR Project ASEM 1999/093. http://www.une.edu.au/carbon/ wpapers.php

Government of Indonesia. 2004. Undang-Undang Republik Indonesia No. 25 Tahun 2004 tentang Sistem Perencanaan Pembangunan Nasional. Jakarta: Sekretariat Kabinet Republik Indonesia.

Greenpeace. 2007. How the Palm Oil Industry is Cooking the Climate. Amsterdam, Netherlands: Greenpeace International.

Hadi A, Haridi M, Inubushi K, Purnomo E, Razie F and Tsuruta H. 2001. Effect of land-use change in tropical peat soil on the microbial population and emission of greenhouse gases. Microbes and Environments. 16:79-86.

Han S. 20 July 2012. Korea Southern Power to buy wood pellets for renewables quota. Bloomberg. http://www.bloomberg.com/news/2012-07-20/ korea-southern-power-to-buy-wood-pellets-forrenewables-quota.html

Hansen MC, Stehman S, Potapov P, Loveland T, Townshend J, DeFries R, Pittman K, Arunarwati B, Stolle F, Steininger M, Carroll M and DiMiceli C. 2008. Humid tropical forest clearing from 2000-2005 quantified by using multitemporal and multiresolution remotely sensed data. Sustainability Science 105(27): 9439-44.

Hansen MC, Stehman SV, Potapov PV, Pittman KW, Margono AB and Stolle F. 2009. Quantifying changes in the rates of forest clearing in Indonesia from 1990 to 2005 using remotely sensed data sets. Environmental Research Letters 4:034001.

Hansen MC, Potapov PV, Moore R, Hancher M, Turubanova SA, Tyukavina A, Thau D, Stehman SV, Goetz SJ, Loveland TR, Kommareddy A, Egorov A, Chini L, Jutice CO and Townshend JRG. 2013. High resolution global maps of 21 st century forest cover change. Science 342:850-53. 
Hardjono J. 1977. Transmigration in Indonesia. Kuala Lumpur: Oxford University Press.

Härdter R and Fairhurst T. 2003. Introduction. In Fairhurst T and Härdter R, eds. Oil Palm: Management for Large and Sustainable Yields. Singapore: Oxford Graphic Printers. 1-12.

Harris NL, Brown S, Hagen SC, Saatchi S, Petrova S, Salas W, Hansen MC, Potapov PV and Lotsch A. 2012. Baseline map of carbon emissions from deforestation in tropical regions. Science 336(6088):1573-76.

Hasan M, Mahlia T and Nur H. 2012. A review on energy scenario and sustainable energy in Indonesia. Renewable and Sustainable Energy Reviews 16:2316-28.

Hemawati R. 5 September 2013. Pemerintah Korsel Tingkatkan Investasi Biomassa di Indonesia. Metrotvnews. Kamis. http://www.metrotvnews. com/metronews/read/2013/09/05/2/179682/ Pemerintah-Korsel-Tingkatkan-InvestasiBiomassa-di-Indonesia

Hergoualc'h K and Verchot L. 2013. Greenhouse gas emission factors for land use and land-use change in Southeast Asian peatlands. Mitigation and Adaptation Strategies for Global Change 19 (6):789-807.

Hermosilla A and Fay C. 2005. Strengthening Forest Management in Indonesia through Land Tenure Reform: Issues and Framework for Action. Washington DC: Forest Trends.

Hertel TW, Burke MB and Lobell DB. 2010. The poverty implications of climate-induced crop yield changes by 2030. Global Environmental Change. https://www.ocf.berkeley.edu/ - marshall/papers/ Hertel_etal_GEC_2010.pdf

Hewitt J. 2011. Flows of Biomass to and from the EU: An Analysis of Data and Trends. Moreton in Marsh, United Kingdom: FERN.

Hoffman A, Hinrichs A and Siegert F. 1999. Fire Damage in East Kalimantan in 1997/98 Related to Land Use and Vegetation Classes: Satellite Radar Inventory Results and Proposals for Further Actions. Report No. 1. Samarinda, Indonesia: Indonesian Ministry of Forests and Estate Crops and German Technical Cooperation Agency.

Holmes D. 2002. Where Have All the Forests Gone? Environment and Social Development East Asia and Pacific Region Discussion Paper series. Washington DC: World Bank.

Hooijer A, Page SE, Canadell J, Silvius M, Kwadijk J, Wosten $\mathrm{H}$ and Jauhiainen J. 2010. Current and future $\mathrm{CO}_{2}$ emissions from drained peatlands in Southeast Asia. Biogeosciences 7:1505-14.
Hooijer A, Page SE, Jauhiainen J, Lee WA, Idris A and Anshari G. 2012. Subsidence and carbon loss in drained tropical peatland. Biogeosciences (9):1053-1071.

Hoscilo A, Page SE, Tansey K and Rieley J. 2011. Effects of repeated fires on land-cover change on peatland in southern Central Kalimantan, Indonesia, from 1973 to 2005 . International Journal of Wildland Fire 20(40):578-88.

Hooijer A, Silvius M, Wosten H and Page SE. 2006. PEAT-CO2 Assessment of CO2 Emissions from Drained Peatlands in SE Asia. Delft: Delft Hydraulics, 36 pp.

Iguchi H. 2012. FIT and Biomass Demand in Japan. Paper presented at the 2012 Can Bio Annual Conference held on 28 November in Vancouver Canada. http://www.canbio.ca/ upload/documents/van-12-presentations/iguchihidetoshi.pdf

Igwe J and Onyegbado C. 2007. A review of palm oil effluent (POME) water treatment. Global Journal for Environmental Research 1(2):54-62.

Indrarto GB, Murharjanti P, Khatarina J, Pulungan I, Ivalerina F, Rahman J, Prana MN, Resosudarmo IAP and Muharrom E. 2012. The Context of REDD+ in Indonesia: Drivers, Agents and Institutions. Working Paper 92. Bogor, Indonesia: Center for International Forestry Research.

Inubushi K, Furakawa Y, Hadi A, Purnomo E and Tsuruta H. 2003. Seasonal changes of CO2 $\mathrm{CH} 4$ and $\mathrm{N} 2 \mathrm{O}$ fluxes in relation to land-use change in tropical peatlands located in coastal area of South Kalimantan. Chemosphere 52:603-08.

Inubushi K, Otake S, Furukawa N, Shibasaki N, Ali M, Itang M and Tsuruta H. 2005. Factors influencing methane emissions from peat soils: Comparison of tropical and temperate wetlands. Nutrient Cycling in Agroecosystems 71:93-99.

IPCC [Intergovernmental Panel on Climate Change]. 2013a. 2013 Supplement to the 2006 IPCC Guidelines for National Greenhouse Gas Inventories, Wetlands. Geneva, Switzerland: Intergovernmental Panel on Climate Change Secretariat.

IPCC [Intergovernmental Panel on Climate Change]. 2013b. Working Group 1 Contribution to the IPCC Fifth Assessment Report (AR5), Climate Change 2013: The Physical Science Basis, Final Draft Underlying Scientific-Technical Assessment, Submitted by the Co-chairs of Working Group 1, IPCC Secretariat. Geneva, Switzerland: 
Intergovernmental Panel on Climate Change Secretariat.

ISPO, 2014. Matriks Perusahaan Perkebunan Berkelanjutan (Penerima Sertifikat ISPO s/d Januari 2014). Indonesian Sustainable Palm Oil (ISPO) Secretariat. http://ispo-org.or.id/images/ matriks_jan14.pdf

ITS. 2011. The Economic Contribution of Indonesia's Forest Based Industries. Melbourne: ITS Global.

IWGFF 2011. Perkiraan Pengunaan Sumber Bahan Baku Indistri Pulp and Paper: Studi Advokasi: PT RAPP \& PT IKPP di Propinsi Riau. Research Report, Jakarta.

Jakarta Post. 13 August 2012. New government regulation threatens forest protection. Jakarta Post.

Jakarta Post. 10 November 2010. Indonesia develops rival sustainable palm oil scheme. Jakarta Post.

Jauhiainen J, Heikkinen J, Martikainen PJ and Vasander H. 2001. $\mathrm{CO}_{2}$ and $\mathrm{CH}_{4}$ fluxes in pristine and peatland converted to agriculture in Central Kalimantan, Indonesia. International Peat Journal 11:43-49.

Jauhiainen J, Hooijer A and Page SE. 2011. Carbon dioxide fluxes in an acacia plantation on tropical peatland. Biogeosciences Discussions (8):82698302.

Jauhiainen J, Takahashi H, Juha Heikkinen EP, Martikainen PJ and Vasander H. 2005. Carbon fluxes from a tropical peat swamp forest floor. Global Change Biology 11:1788-97.

Jauhiainen J, Vasander H, Jaya A, Takashi I, Heikkinen J and Martikinen P. 2004. Carbon balance in managed tropical peat in Central Kalimantan, Indonesia. In J. Päivänen, ed. Proceedings of the 12th International Peat Congress, Tampere, Finland.

Jupesta J, Harayama Y and Paryail G. 2011a. Sustainable business model for biofuel industries in Indonesia. Sustainability Accounting, Management and Policy Journal 2(2):231-47.

Jupesta J, Parayil G, Haryama. 2011b. The development of biofuel in Indonesia from diffusion and stakeholder interactions. http:// umconference.um.edu.my/upload/163-1/ Paper\%2012\%20ltst.pdf

Jurgens E. 2007. Strategies to Reduce Carbon Emissions from the Pulp and Paper and Plantation Sectors in Indonesia. Draft paper produced for the Indonesian Forest Climate Alliance (IFCA) Consolidation Report.

Karim S. 2013. Kaltim Setop Izinkan Lahan Tambang dan Perkebunan Baru, 7 April 2013. https://cgclipping.wordpress.com/2013/04/12/ kaltim-setop-izinkan-lahan-tambang-danperkebunan-baru/

Ketterings Q, Coe R, Van Noordwijk M, Ambagau $\mathrm{Y}$ and Palm C. 2001. Reducing uncertainty in the use of allometric biomass equations for predicting above-ground tree biomass in mixed secondary forests. Forest Ecology and Management 146:199-209.

Knudson T. 21 January 2009. The cost of the biofuel boom on Indonesia's forests. The Guardian. http://www.guardian.co.uk/ environment/2009/jan/21/network-biofuels

Koh L and Wilcove D. 2008. Is oil palm agriculture really destroying tropical biodiversity. Conservation Letters, 1(2):60-64.

Lang C. 2013a. Indonesia's president extends forest moratorium for 2 more years. REDD Monitor, 15 May 2013. http://www.redd-monitor. org/2013/05/15/indonesias-president-extendsforest-moratorium-for-two-more-years/

Lang C. 2013b. Indonesia's constitutional court returns customary forests to indigenous peoples. REDD Monitor, 17 May 2013.

Lang C. 2013c. Indonesia's REDD+ agency will not be able to take any action says Ministry of Forestry Secretary General. REDD Monitor, 11 September 2013.

Lang C. 2013d. Indonesia's rate of deforestation has doubled under the moratorium. REDD Monitor, 11 December 2013.

Langner A, Miettinen J and Siegert F. 2007. Land cover change 2002-2005 in Borneo and the role of fire derived from MODIS imagery. Global Change Biology 13:2329-40.

Larson D. 1996. Indonesia's Palm Oil Sub-sector. Policy Research Working Paper 1654, Policy Research Dissemination Center. Washington DC: World Bank.

Lawlor and Huberman. 2008. Reducing emissions from deforestation and forest degradation (REDD) and human doing harm? In Angelsen A, ed. Moving Ahead with REDD: Issues, Options and Implications. Bogor, Indonesia: Center for International Forestry Research.

Lim DW. 2012. Experiences of biomass power and pellets in Asia. Paper presented at World Bioenergy 2012 held in Jonkoping, Sweden, 29 May 2012. http://energy-indonesia. com/03dge/biomas\%20hatsuden.pdf

Lubis A. 23 April 2013. Forestry Ministry to reopen log export market to boost price. Jakarta Post.

Ludang Y and Palangkajaya H. 2007. Biomass and carbon content in tropical forest, Kalimantan. 
Journal of Applied Sciences in Environmental Sanitation 2(1):7012.

MacKinnon K, Hatta G, Halim H and Mangalik A. 1996. The Ecology of Kalimantan. The Ecology of Indonesia Series, Volume III. Singapore: Periplus Editions.

Margono B, Turubanova S, Zhuravela I, Potapov P, Tyukavina A, Baccini A, Goetz $S$ and Hansen M. 2012. Mapping and monitoring deforestation and forest degradation in Sumatra (Indonesia) using Landsat time series data sets from 1990-2010. Environmental Research Letters 7:3. http://dx.doi. org/10.1088/1748-9326/7/3/034010 .

Marshall A and Beehler B. 2007. The Ecology of Papua. The Ecology of Indonesia Series, Volume VI. Singapore: Periplus Editions.

Mather A S 1992 The forest transition Area 24:367-79.

Matondi B, Harevik K and Beyene A. 2011. Biofuels, Land Grabbing and Food Security in Africa. London, United Kingdom:

Zed Books.

Mattangkilang T. 10 May 2013. Palm oil planters bid to end deforestation moratorium. Jakarta Globe.

McAndrews C. 1978. Transmigration in Indonesia: Prospects and problems. Asian Survey 18(5):458-72.

McCarthy J. 2000. The changing regime: Forest property and reformasi in Indonesia. Development and Change 31:91-129.

Mee-Young C. 2009. South Korea targets 2020 emissions at 30 percent below forecast. Reuters, Nov 16. http://www.reuters.com/ article/2009/11/17/us-korea-emissionidUSTRE5AG0DN20091117

Mel M, Ihsan I and Adesta Y. 2010. Biogas Energy Potential in Riau, Indonesia. Kuala Lumpur, Malaysia: International Islamic University Malaysia.

Melling L, Hatano R and Goh KJ. 2005. Methane fluxes from three ecosystems in tropical peatland of Sarawak, Malaysia. Soil Biology and Biogeochemistry 37:1445-53.

Melling L, Hatano R and Goh KJ. 2007. Nitrous oxide emissions from three ecosystems in tropical peatland of Sarawak, Malaysia. Soil Science and Plant Nutrition 53:792-805.

[MEMR] Ministry of Energy and Mineral Resources. 2012. Handbook of Energy and Economic Statistics of Indonesia. Jakarta, Indonesia: Center for Data and Information on Energy and Mineral Resources, Ministry of Energy and Mineral Resources.

Miettinen J, Shi C and Liew S. 2011. Deforestation rates in insular Southeast Asia between 2000 and 2010. Global Change Biology 17:2261-70.

[MoA] Ministry of Agriculture. 2013. Agricultural Statistical Database. http://aplikasi.deptan.go.id/ bdsp/index-e.asp

[MoE] Ministry of Environment. 2010. Indonesia's Second National Communication under the United Nations Framework Convention on Climate Change (UNFCCC). Jakarta: MoE.

[MoF] Ministry of Forestry. 2012. Statistik Kehutanan Indonesia 2011, Kementerian Kehutanan, Indonesia. Jakarta: MoF.

[MoF] Ministry of Forestry. 2011. Rencana Kehutanan Tingkat Nasional (RKTN), Tahun 2011-2030, Kementerian Kehutanan. Jakarta: MoF.

[MoF] Ministry of Forestry. 2009. Eksekutif Data Strategis Kehutanan 2009. Jakarta: MoF.

[MoF] Ministry of Forestry. 2008. IFCA Consolidation Report, Reducing Emissions from Deforestation and Forest Degradation in Indonesia. Jakarta: MoF.

[MoF] Ministry of Forestry and [FAO] Food and Agriculture Organization. 1990. Situation and Outlook of the Forestry Sector in Indonesia. Forest Resource Base, Volume 2. Jakarta: MoF and FAO.

Monbiot G. 26 March 2007. If we want to save the planet, we need a five year moratorium on biofuels. Manchester Guardian. http://www. guardian.co.uk/commentisfree/2007/mar/27/ comment.food

Mongabay. 22 May 2012a. Indonesia revises moratorium map; makes contested orangutan forest off-limits. Mongabay. http://news. mongabay.com/2012/0522-indonesiamoratorium-map-revision.html

Mongabay. 25 May 2012b. Indonesia’s deforestation rate falls, says Ministry of Forestry. Mongabay. http://news.mongabay. com/2012/0526-deforestation-indonesia-map. html\#KJuFCsfdYrKaFdsb.99

Murayama $S$ and Bakar ZA. 1996. Decomposition of tropical peat soils. Japan Agricultural Research Quarterly 30:153-58.

Murdiyarso D, Dewi S, Lawrence D and Seymour F. 2011. Indonesia's Forest Moratorium: A Stepping Stone to Better Forest Governance? Working Paper 76. Bogor, Indonesia: Center for International Forestry Research. 
Murdiyarso D, Hergoualc'h K and Verchot L. 2010. Opportunities for reducing greenhouse gas emissions in tropical peatlands. PNAS 107(46):19655-60.

Murdiyarso D, Van Noordwijk M, Wasrin U, Tomich T and Gillison A. 2002. Environmental benefits and sustainable land use options in the Jambi transect, Sumatra, Indonesia. Journal of Vegetation Science (13):429-38.

Nagi J, Ahmen S and Nagi F. 2008. Palm Biodiesel an Alternative Green Renewable Energy for the Energy Demands of the Future. Kuala Lumpur, Malaysia: International Conference on Construction and Building Technology (ICCBT).

Natahadibrata N. 25 April 2013. With or without moratorium, RI forests still under threat. Jakarta Post.

Naturealert. 9 March 2009. South Korea to produce wood pellet fuel in Indonesia. http://naturealert. blogspot.com/2009/03/south-korea-to-producewood-pellet-fuel.html

Naylor RL, Liska AJ, Burke MB, Falcon WP, Gaskell JC, Rozelle SD and Cassman KG. 2007. The ripple effect: Biofuels, food security and the environment. Environment Magazine: Science and Policy for Sustainable Development. http:// www.environmentmagazine.org/Archives/ Back\%20Issues/November\%202007/NaylorNov07-full.html

Nellemann C, Miles L, Kaltenborn BP, Virtue M and Ahlenius H, eds. 2007. The Last Stand of the Orangutan - State of Emergency: Illegal Logging, Fire and Palm Oil in Indonesia's National Parks. Arendal, Norway: United Nations Environment Programme and GRID-Arendal.

Nelson G and Pangabean M. 1991. The costs of Indonesian sugar policy: A policy analysis matrix approach. American Journal of Agricultural Economics 73(3):703-12.

Obidzinski K, Andriani R, Komarudin H and Andrianto A. 2012. Environmental and social impacts of oil palm plantations and their implications for biofuel production in Indonesia. Ecology and Society 17(1):25. http://dx.doi. org/10.5751/ES-04775-170125

Obidzinski K and Barr C. 2002. The Effects of Decentralisation on Forests and Forest Industries in Berau District, East Kalimantan. Bogor, Indonesia: Center for International Forestry Research.

Obidzinski K and Dermawan A. 2012. New round of pulp and paper expansion in Indonesia: What we know and what do we need to know? ARD
Learning Exchange 2012. http://www.cifor. org/ard/documents/background/Day5.pdf

Obidzinski K and Dermawan A. 2010. Smallholder timber plantation development in Indonesia: What is preventing progress? International Forestry Review 12(4):339-48.

Obidzinski K, Takahashi I, Dermawan A, Komarudin $\mathrm{H}$ and Andrianto A. 2013. Can large scale land acquisition for agro-development in Indonesia be managed sustainably? Land Use Policy 30(1):952-965 http://dx.doi.org/10.1016/j. landusepol.2012.06.018

Onwueme IC. 2002. Cassava in Asia and the Pacific. In Hillocks RJ, Thresh JM and Belletti AC, eds. Cassava: Biology, Production and Utilization. Oxfordshire, United Kingdom: CAB International.

Page SE, Morrison R, Malins C, Hooijer A, Rieley JO and Jauhiainen J. 2011. Review of Peat Surface Greenhouse Gas Emissions from Oil Palm Plantations in Southeast Asia. White Paper 14, Indirect Effects of Biofuel Production Series. Washington, DC: International Council of Clean Transportation.

Page SE, Rieley JO, Shotyk B and Weiss D. 1999. Interdependence of peat and vegetation in a tropical peat swamp forest. Philosophical Transactions of the Royal Society of London $B$ (354):1885-97.

Page SE, Siegert F, Rieley JO, Boehm HV, Jaya A and Limin S. 2002. The amount of carbon released from peat and forest fires in Indonesia during 1997. Nature (420):61-65.

Pangestu M. 1991. East Kalimantan: Beyond the timber boom. In Hill H, ed. Unity and Diversity: Regional Economic Development in Indonesia since 1970. Singapore: Oxford University Press.

Paoli GD, Yaap B, Wells PL and Sileuw A. 2010. CSR, oil palm and the RSPO: Translating boardroom philosophy into conservation action on the ground. Tropical Conservation Science 3(4):438-46.

Papenfus MM. 2001. Investing in Oil Palm: An Analysis of Independent Smallholder Oil Palm Adoption in Sumatra, Indonesia. Southeast Asia Policy Research Working Paper 15. Bogor, Indonesia: ICRAF SEA-Asia.

Pasandaran C. 23 November 2012. Forest Ministry pushes to continue deforestation moratorium, House pushes back. Jakarta Globe. 
Peluso N. 1992. Rich Forests, Poor People: Resource Control and Resistance in Java. Berkeley, California: University of California Press.

Perry N. 21 February 2010. Jatropha in Indonesia: From hot to rot for wonder crop. Jakarta Post.

Pirard P and Cossalter C. 2006. The Revival of Industrial Forest Plantations in Indonesia's Kalimantan Province: Will They Help Eliminate Fiber Shortfalls at Sumatran Pulp Mills or Feed the China Market. Bogor, Indonesia: Center for International Forestry Research.

Poffenberger M. 1997. Rethinking Indonesian forest policy. Beyond the timber barons. Asian Survey 37(5):453-469.

Pohl C. 2010. Jatropha: Money Doesn't Grow on Trees: Ten Reasons Why Jatropha Is Neither a Profitable nor Sustainable Investment. Issue 120. Amsterdam: Friends of the Earth International.

Potter L. 2011. Swidden, oil palm, and food security in West Kalimantan, Kasarinlan. Philippine Journal of Third World Studies 26(1-2):252-63.

Potter L. 1991. Environmental and social aspects of timber exploitation in Kalimantan 1967-1989. In Hardjono J, ed. Indonesia: Resources, Ecology and the Environment. Singapore: Oxford University Press. 177-211.

Potter L and Badcock S. 2001. The Effects of Indonesia's Decentralisation on Forests and Estate Crops: Case Study of Riau Province, the Original Districts of Kampar and Indragiri Hulu. Bogor, Indonesia: Center for International Forestry Research.

Pöyry. 2011. Pellets - Becoming a Global Commodity? Pellet Supply and Demand, Policies and Cost Competitiveness. Perspectives on the Global Pellet Market, 2010-2020. http://www.poyry. $\mathrm{com} /$ sites/default/files/imce/files/pelletsglobalmarket2020-april2011-biofutures.pdf

Prakesh A. 2005. Cassava: International Market Profile: Background Paper for the Competitive Commercial Agriculture in Sub-Saharan Africa. The World Bank and Food and Agriculture Organization. http:// siteresources.worldbank.org/INTAFRICA/ Resources/257994-1215457178567/Cassava_ Profile.pdf.

[PRB] Population Reference Bureau. 2012. World Population Data Sheet. Washington, DC: PRB.

Priyambodo. 28 August 2013. Indonesian govt aims to raise mandatory level of biofuel in diesel oil. Antara News. http://www.antaranews.com/en/ news/90462/indonesian-govt-aims-to-raisemandatory-level-of-biofuel-in-diesel-oil
Proforest. 2003. Palm Oil, Forests and Sustainability. Oxford, United Kingdom: Proforest.

Rahayu S, Lusiana B and van Noordwick M. 2005. Above ground carbon stock assessment for various land use systems in Nunukan, East Kalimantan. In Lusiana B, van Noordwick M and Rahayu S, eds. Carbon Stock Monitoring in Nunukan, East Kalimantan: A Spatial and Modelling Approach. Bogor, Indonesia: World Agroforestry Center. 21-34.

Ravindranath NH, Manuvie R, Fargione J, Canadell JG, Berndes G, Woods J and Sathaye J. 2009. Greenhouse gas implications of land use and land conversion to biofuel crops. In Howarth RW and Bringezu S, eds. Biofuels Environmental Consequences and Interactions with Changing Land Use. New York: Island Press. 111-125.

Reijnders L and Huijbregts MAJ. 2008. Palm oil and the emission of carbon-based greenhouse gases. Journal of Cleaner Production 16:477-82.

[RePPProT] Regional Physical Planning Programme for Transmigration. 1990. The Land Resources of Indonesia: A National Overview. Final report. London and Jakarta: Land Resources Department of the Overseas Development Administration and Ministry of Transmigration.

Restianti Y and Gheewala SH. 2012. Environmental and life cycle cost assessment of cassava ethanol in Indonesia. Journal of Sustainable Energy and Environment 3:1-6.

Rondonuwu O. 2012. Indonesia forest moratorium won't meet climate pledge: Norway. Reuters 22 May, 2012 8:32am.

Ros J, Olivier J, Notenboom J, Croezen $\mathrm{H}$ and Bergsma G. 2012. Sustainability of biomass in a bio-based economy. The Hague, Netherlands: PBL Netherlands Environmental Assessment Agency.

Rosalina. 18 September 2012. Target Produksi Swasembada Gula 2014 diturunkan. Tempo. http://www.tempo.co/read/ news/2012/09/18/090430205/Target-ProduksiSwasembada-Gula-2014-Diturunkan

Roundtable on Sustainable Palm Oil. 2004. Roundtable on Sustainable Palm Oil. http:// www.rspo.org/en/member/listing/membership

Runge $\mathrm{C}$ and Senauer B. 2008. How ethanol fuels the food crisis. Foreign Affairs: 28 May. http:// www.foreignaffairs.com/articles/64915/c-fordrunge-and-benjamin-senauer/how-ethanol-fuelsthe-food-crisis

Saatchi SS, Houghton RA, Dos Santos ARC, Soares JV and Yu Y. 2007. Distribution of aboveground 
live biomass in the Amazon Basin. Global Change Biology 13:816-37.

Samadhi N. 2013. Indonesia One Map: Assuring Better Delivery of National Development Goals. Presentation delivered by Nirata Samadhi, 5th Deputy Head of President's Delivery Unit for Development Monitoring and Oversight, to Geospatial World Forum 2013, Rotterdam, 12-13 May 2013.

Sanderson K. 2006. US biofuels: A field in ferment. Nature 444(7 December):673-76.

Sekala. 2013. Forest Climate Center. http:// forestclimatecenter.org/

Sentana M. 30 April 2013. Battle over fuel subsidies looms in Indonesia. Wall Street Journal.

Shirakawa Y, Yokoyama S and Imou K. 2010. Impact of direct land use change process on lifecycle greenhouse gas emissions of palm oil derived biodiesel. Journal of the Japanese Institute of Energy 89:649-57.

Siegert F and Hoffmann A. 2000. The 1998 forest fires in East Kalimantan (Indonesia): A quantitative evaluation using high resolution, multi-temporal ERS-2 SAR images and NOAA-AVHRR hotspot data. Remote Sensing of Environment 72:64-77.

Silitonga A, Atabana A, Mahlia T, Masjuki H, Badruddin A and Mekhilef S. 2011. A review on prospect of Jatropha curcas for biodiesel in Indonesia. Renewable and Sustainable Energy Reviews 15:3733-56.

Sindonews. 26 August 2013. Perusahaan Korsel kembangkan Wood Pellet di Indonesia. Sindonews. http://ekbis.sindonews.com/ $\mathrm{read} / 2013 / 08 / 26 / 34 / 775580 /$ perusahaankorsel-kembangkan-wood-pellet-di-indonesia

Sizer N, Stolle F, Minnemeyer S. 2013. Indonesia’s forest fire and haze risk remain high. EcoBusiness. http://www.eco-business.com/opinion/ indonesian-forest-fire-and-haze-riskremains-high/

Slette J and Meylinah S. 2013. Indonesia Sugar Annual Report 2013. GAIN Report Number ID1314. Washington, DC: USDA Foreign Agricultural Service, Global Agricultural Information Network.

Slette J and Meylinah S. 2012. Indonesia Sugar Annual Report 2012. GAIN Report. Washington, DC: USDA Foreign Agricultural Service.

Slette J and Wiyono E. 2012. Indonesia Biofuels Annual 2012. GAIN Report. Washington, DC: USDA Foreign Agricultural Service, Global Agriculture Information Network.
Sommerville M. 2013. Land Tenure and REDD+: Risks to Property Rights and Opportunities for Economic Growth. Property Rights and Resource Governance Briefing Paper 11. Washington, DC: US Agency for International Development.

Stoler AL. 1985. Capitalism and Confrontation in Sumatra's Plantation Belt, 1870-1979. Ann Arbor: Michigan Press.

Streck C. 2007. Protecting Forests to Mitigate Global Climate Change. http://www.climatefocus.com/ downloads/publications/Climate_Change_ Deforestation.pdf

Sugiono T and Mayrowani H. 2009. The determinants of cassava productivity and price under the farmers' collaboration with the emerging cassava processors: A case study in East Lampung Indonesia. Journal of Development and Agricultural Economics 1(5):114-20.

Suharto R. 2012. ISPO Certification - An Update. Presentation by the Indonesian Sustainable Palm Oil Commissions at IPOSC 2012, Putrajaya Marriot Hotel, Malaysia.

Sunderlin WD, Angelsen A, Belcher B, Burgers P, Nasi R, Santoso L and Wunder S. 2005. Livelihoods, forests, and conservation in developing countries: An overview. World Development 33(9):1383-1402.

Sunderlin WD and Resosudarmo IAP. 1996. Rates and Causes of Deforestation in Indonesia: Towards a Resolution of the Ambiguities. CIFOR Occasional Paper 9. Bogor, Indonesia: Center for International Forestry Research.

Taylor M. 26 April 2013. Indonesia cuts crude palm oil tax to 9\% for May. Reuters News. http:// in.reuters.com/article/2013/04/26/indonesiapalm-tax-idINJ9N09F01120130426

Taylor M and Supriatna Y. 2013. Indonesia's biodiesel take-up to lag reform target. Reuters, 27 November 2013.

Tomich T, de Foresta H, Dennis R, Ketterings Q, Murdiyarso D, Palm C, Stolle F, Suyant and van Noordwijk M. 2002. Carbon offsets for conservation and development in Indonesia. American Journal of Alternative Agriculture 17(3):125-37.

Torello A. 17 October 2012. EU makes radical shift on biofuels. Wall Street Journal.

[UKP4] President's Delivery Unit for Development Monitoring and Oversight. 2012. One Map Indonesia. Powerpoint presentation by Unit Kerja Presiden Bidang Pengawasan dan Pengendalian Pembangunan, September 2012.

[USDA] United States Department of Agriculture. 2012a. Indonesia: Stagnating Rice Production 
Ensures Continued Need for Imports. Commodity Intelligence Report. Washington, DC: USDA.

[USDA] United States Department of Agriculture. 2012b. Sugar: World Markets and Trade.

Washington, DC: United States Department of Agriculture, Foreign Agricultural Service.

US Energy Information Administration. 2011. International Energy Statistics. http://www. eia.gov/cfapps/ipdbproject/IEDIndex3. cfm? tid=79\&pid=79\&aid=1

Van der Eng P. 1998. Cassava in Indonesia: A historical re-appraisal of an enigmatic food crop. Southeast Asian Studies 36(1):3-31.

Van der Werf GR, Dempewolf J, Trigg SN, Randerson JT, Kasibhatia PS, Giglio L, Murdiyarso D, Peters W, Morton DC, Collatz GJ, Dolman AJ and DeFries RS. 2008. Climate regulations of fire emissions and deforestation in equatorial Asia. Proceedings of the National Academy of Sciences of the United States of America 105:20350-55.

Verchot LV, Petkova E, Obidzinski K, Atmadja S, Yuliani EL, Dermawan A, Murdiyarso D and Amira S. 2010. Reducing forestry emissions in Indonesia. Bogor, Indonesia: Center for International Forestry Research.

Verner V, Herak D, Simanjuntak S and Andert L. 2012. Perspectives of increasing biodiesel production through introduction of Jatropha curcas $\mathrm{L}$. into subsistence farming systems: Experience from North Sumatra, Indonesia. http://tf.llu.lv/conference/proceedings2012/ Papers/073_Verner_V.pdf.

Verwer C, van der Meer P and Nabuurs G. 2008. Review of Carbon Flux Estimates and Other Greenhouse Gas Emissions from Oil Palm Cultivation on Tropical Peatlands Identifying the Gaps in Knowledge. Wageningen, Netherlands: Alterra.

Wakker E. 2005. Greasy Palms: The Social and Ecological Impacts of Large-Scale Oil Palm Plantation Development in South Asia. London: Friends of the Earth.

Waring RH, Way J, Hunt ER Jr, Morrissey L, Ranson KJ, Weishampel JF, Oren R and Franklin SE. 1995. Imaging radar for ecosystem studies. BioScience 45:715-23.

Warr P. 2011. Food Security vs Food Self Sufficiency, the Indonesian Case. Working Paper in Trade and Development. Canberra: Australian National University.
[WCS] Wildlife Conservation Society. 2010. Oil Palm, Biodiversity and Indonesian Law. Bogor, Indonesia: WCS.

Westlake DF. 1966. The biomass and productivity of glyceria maxima: I. Seasonal changes in biomass. Journal of Ecology 54:745-53.

White B. 1983. Agricultural Involution and Its Critics: Twenty Years after Clifford Geertz. Working Paper Series 6. The Hague, Netherlands: Institute of Social Studies.

Wilmar. 2011. Staying the Course through Challenging Times. Sustainability Report 2011. Singapore: Wilmar.

Winrock International. 2009. Implications of Biofuel Sustainability. Arlington: Winrock International.

Wirawan S and Tambunan A. 2006. The Current Status and Prospects of Biodiesel Development in Indonesia: A Review. Paper presented to the Third Asia Biomass Workshop, 16 November 2006, Tsukuba, Japan.

Wood Resource Quarterly. 2012. South Korea and Japan will become large importers of pellets and energy chips in the coming decade. Reports the Wood Resource Quarterly. http://forestindustry. $\mathrm{com} /$ feature-article/200/south-korea-and-japanwill-become-large-importers-pellets-and-energychips-comin

World Bank. 1994. Indonesia - Stability, Growth and Equity in Repelita VI. Report No. 12857-IND, Country Department II, East Asia and Pacific Region. Washington DC: World Bank.

World Bank. 2006. Sustaining Economic Growth, Rural Livelihoods, and Environmental Benefits: Strategic Options for Forest Assistance in Indonesia. Jakarta: World Bank.

Wösten JMH, Ismail AB and van Wijk ALM. 1997. Peat subsidence and its practical implications: A case study in Malaysia. Geoderma 78:25-36.

[WWF] World Wildlife Fund. 2007. Rain Forest for Biodiesel? Ecological Effects of Using Palm Oil as a Source of Energy. Frankfurt: WWF Germany.

Yamakura T, Hagihara A, Sukardjo S and Ogawa H. 1986. Above ground biomass in tropical rain forest stands in Indonesian Borneo. Vegetatio 68:71-82.

Yulisman L. 10 January 2013. Palm oil biofuel to curb oversupply. Jakarta Post.

Zoological Society of London. 2012. Musim Mas: Establishing Biogas Plants to Process Palm Oil Mill Effluent. http://www.sustainablepalmoil.org/ growers-millers/millers/case-studies/musim-mas-2/ 


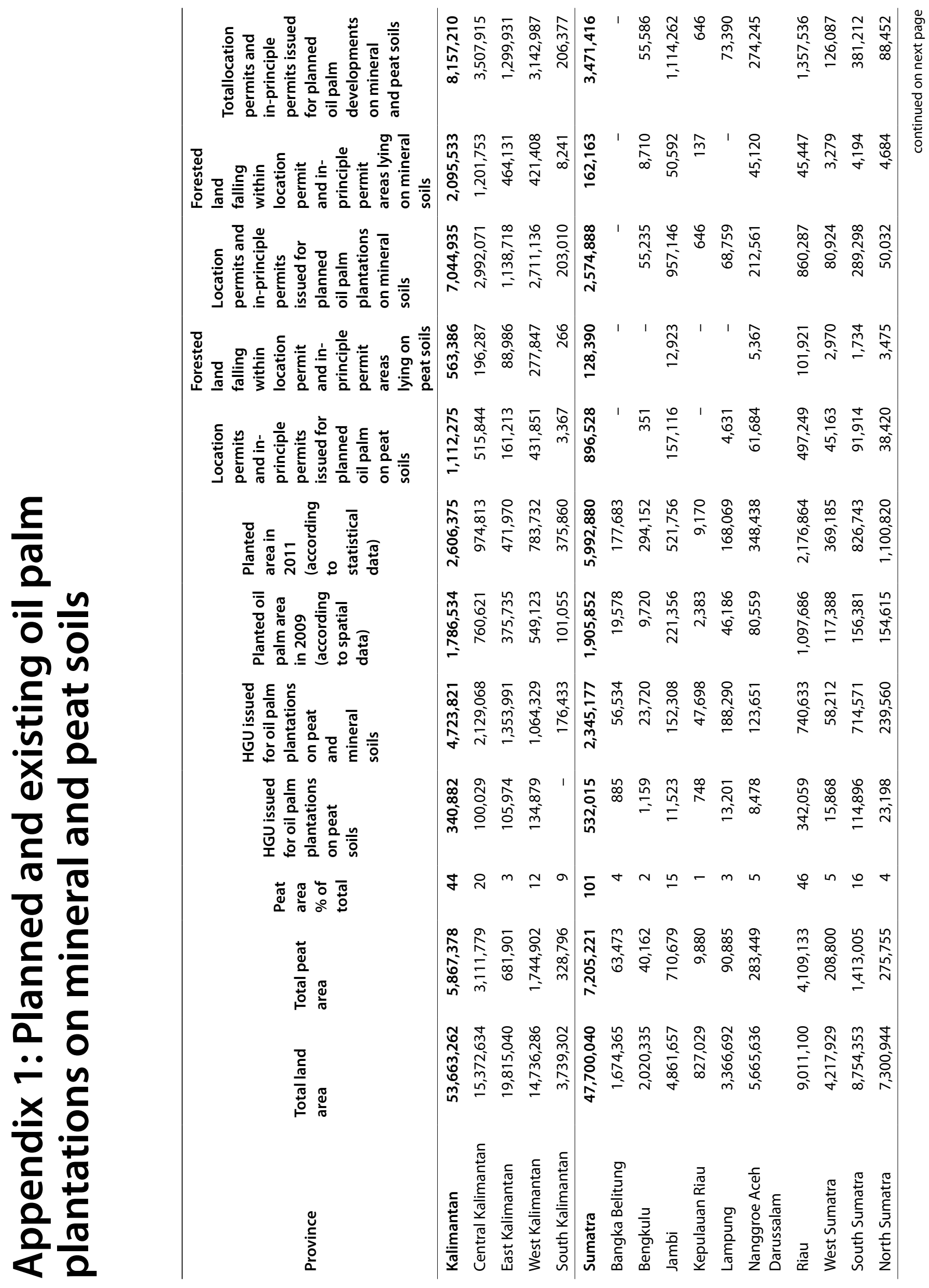




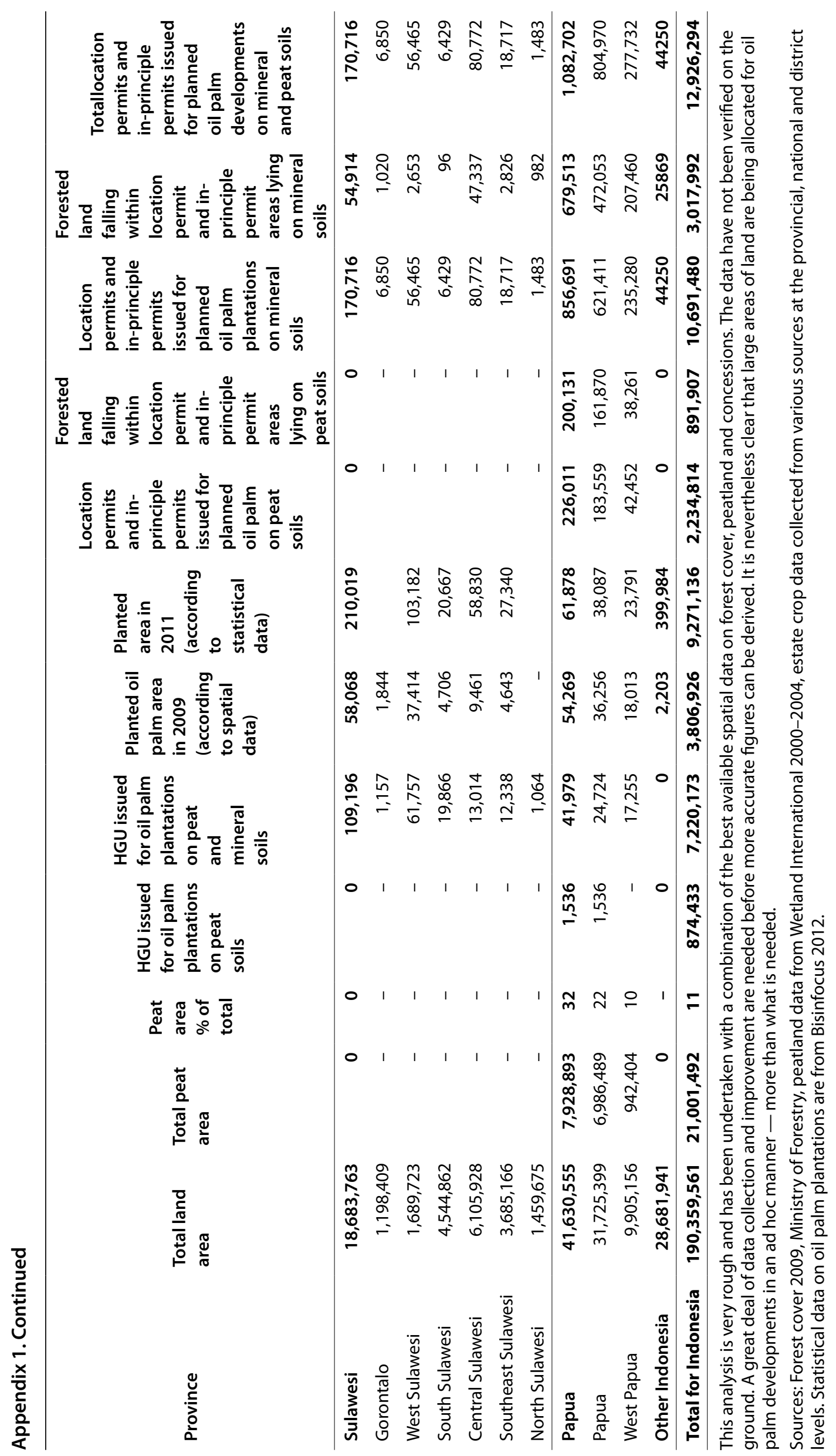



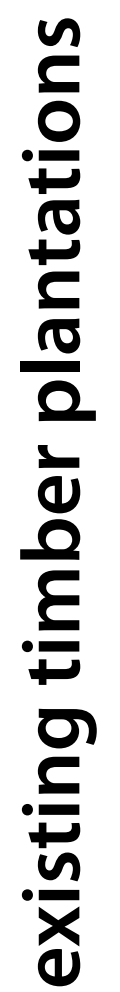

든 $\frac{n}{\circ}$

ర

$\mathscr{0} \pi$

들

훙

ำ

i

증 인

을

ह

选 ธ

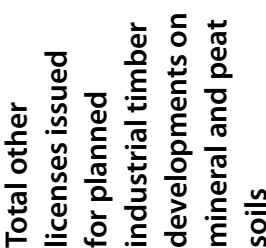

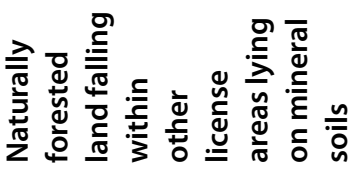

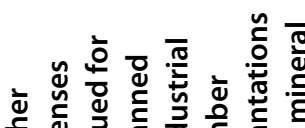

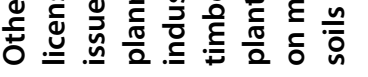

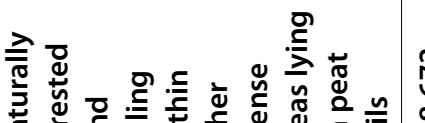

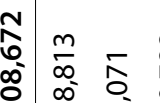

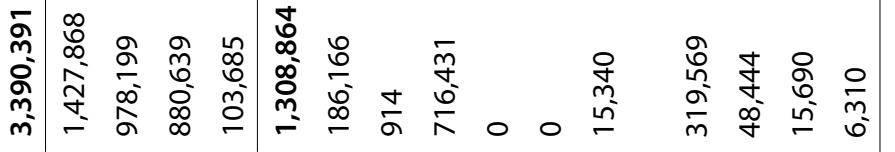

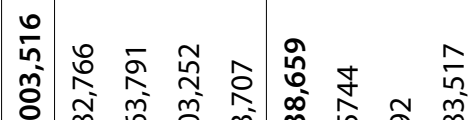

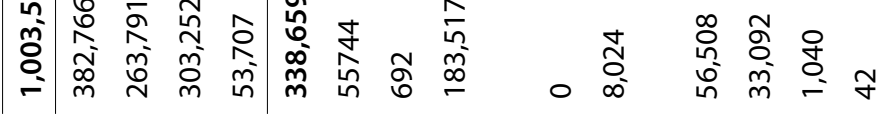

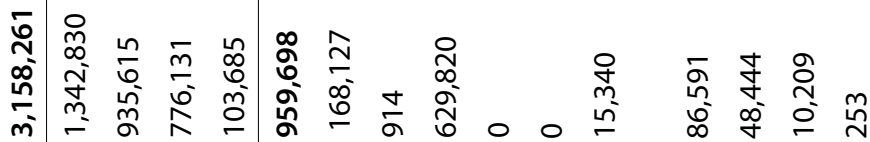

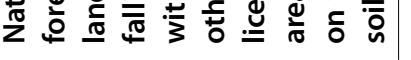

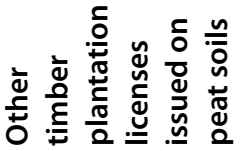

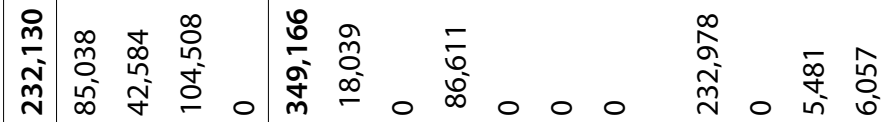

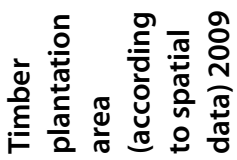

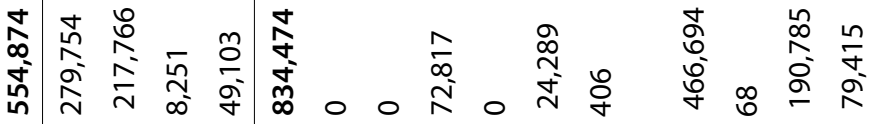

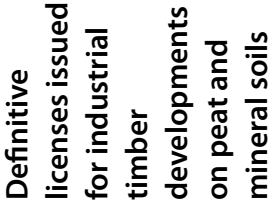

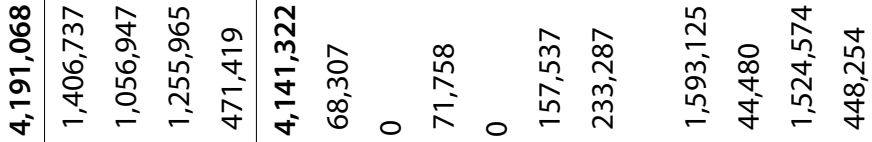

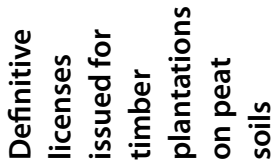

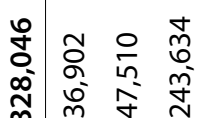

柋

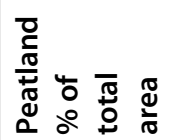

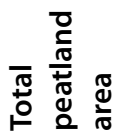

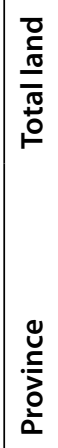

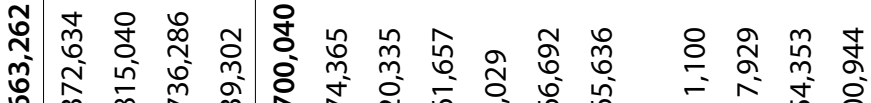

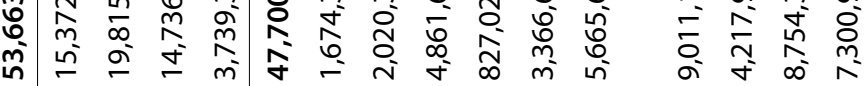

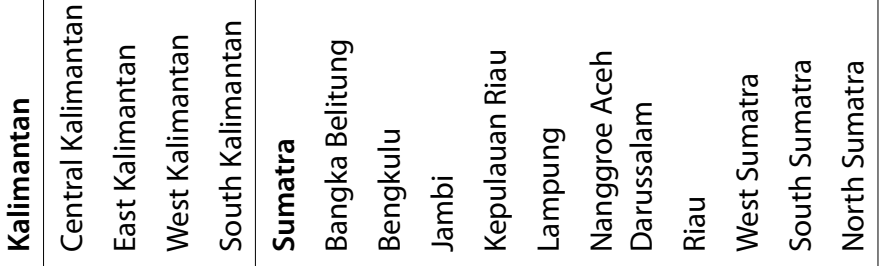




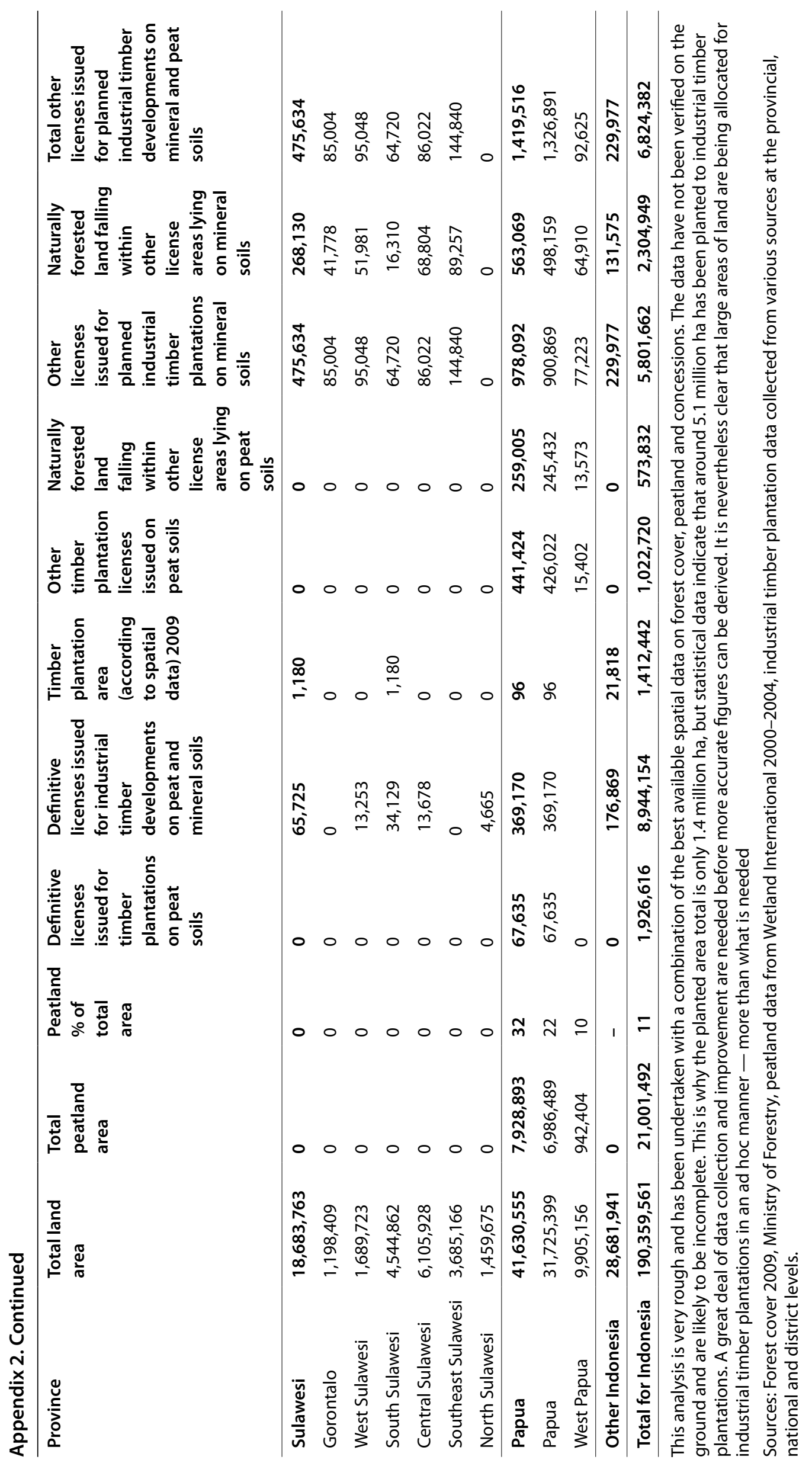




\section{Appendix 3: Location of estate crop plantation licenses in Kalimantan}

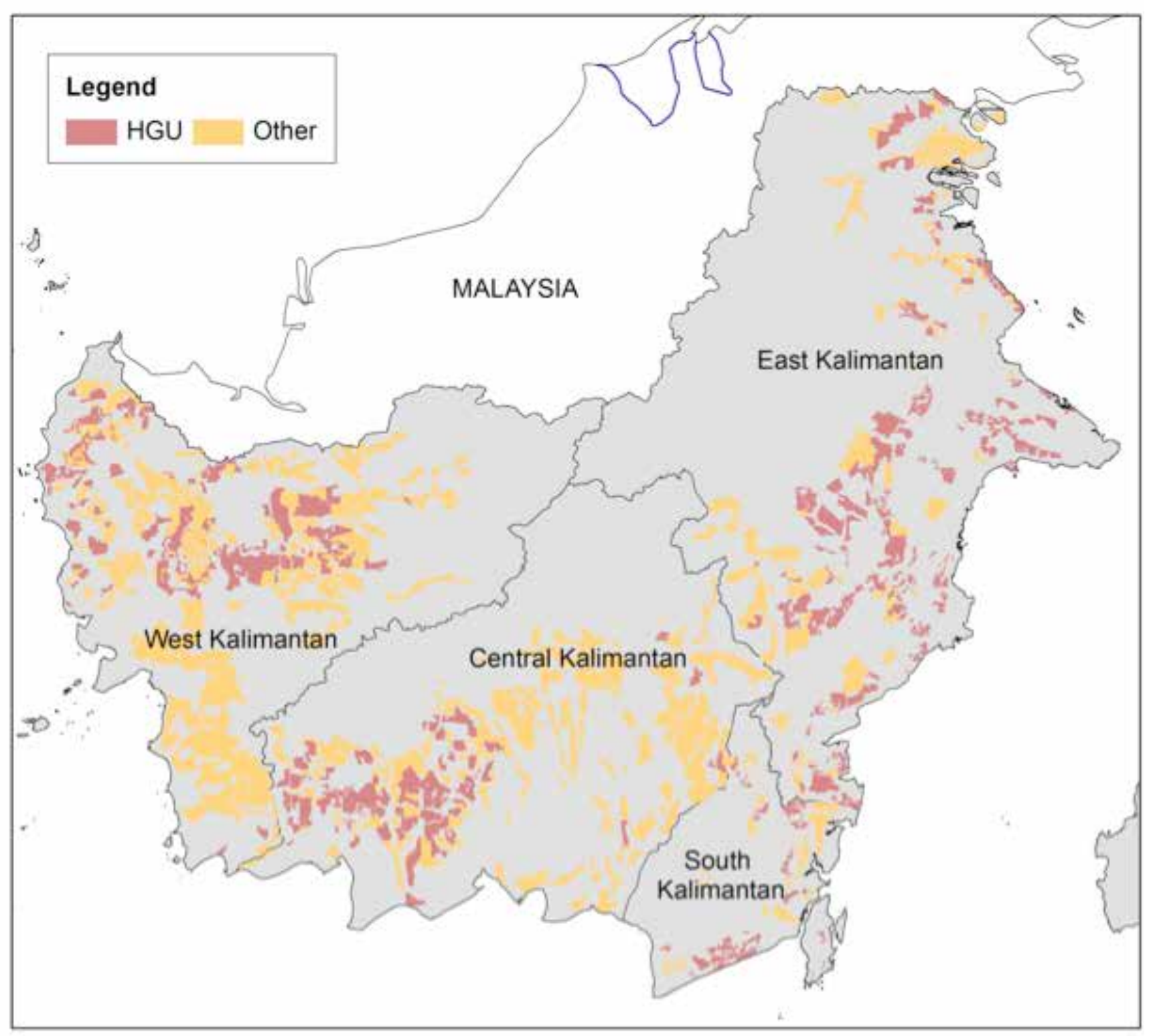

Source: Authors 


\section{Appendix 4: Location of estate crop plantation licenses in Sumatra}

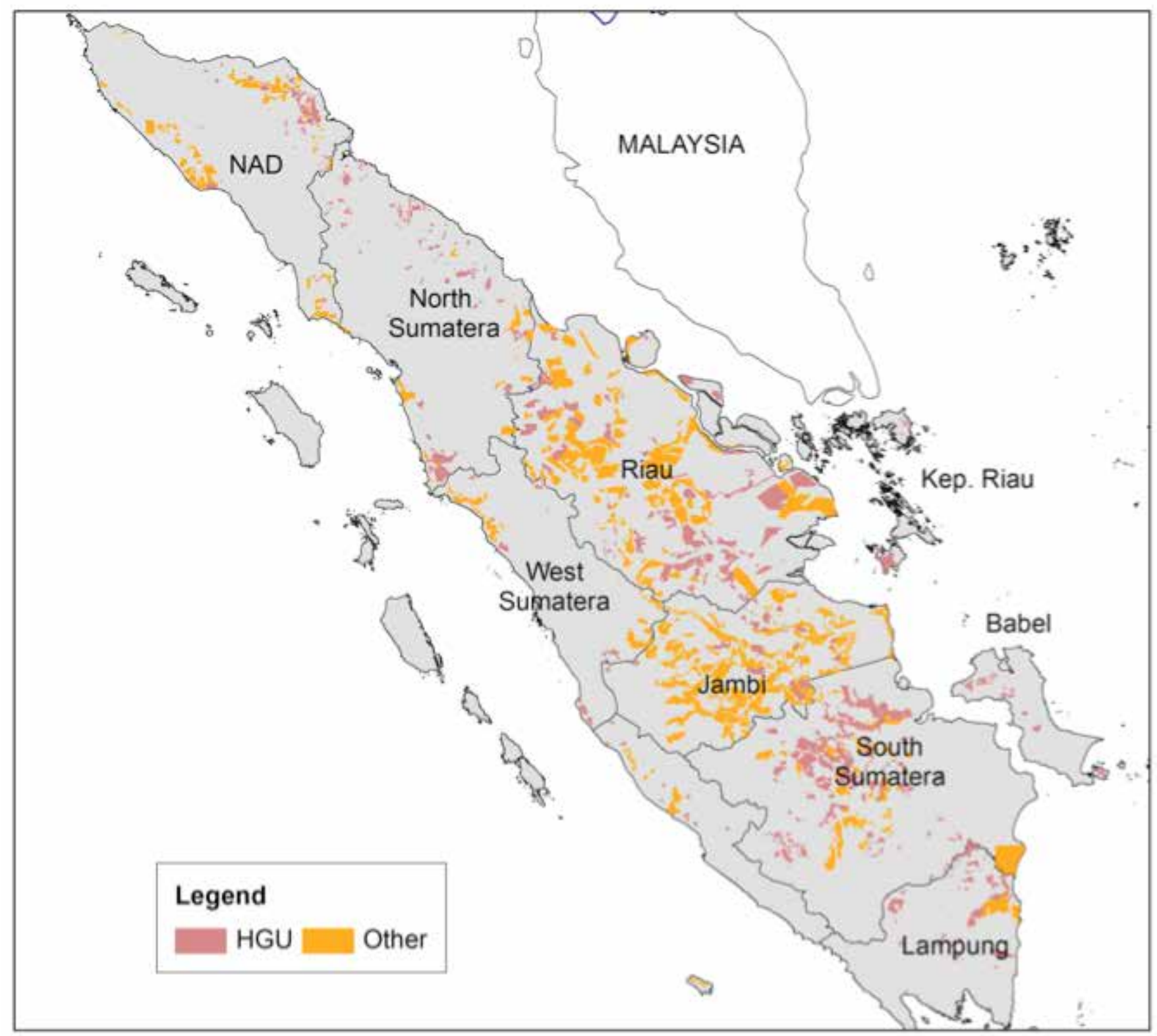




\section{Appendix 5: Location of estate crop plantation licenses in Papua}

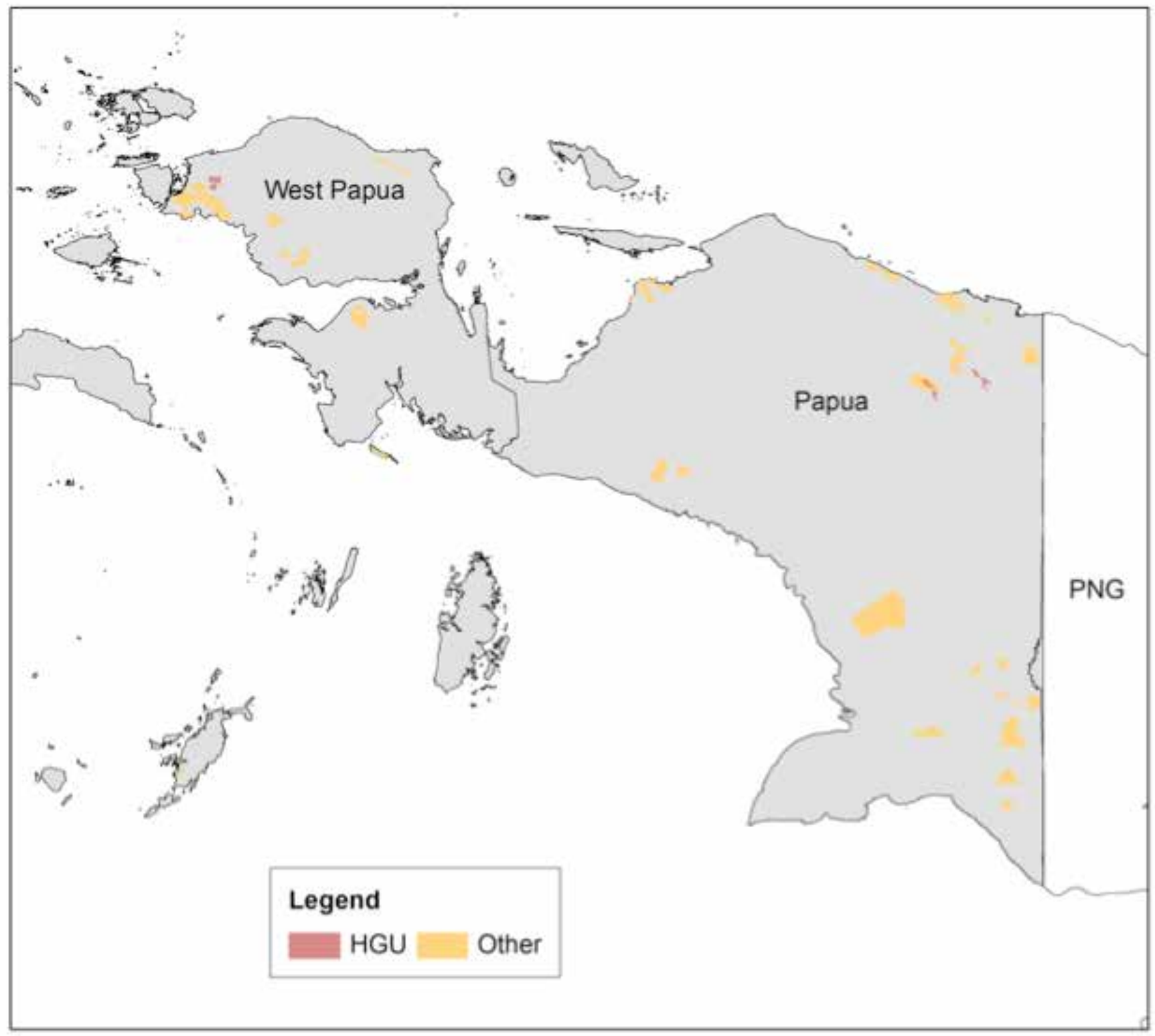




\section{Appendix 6: Location of timber plantation licenses in Kalimantan}

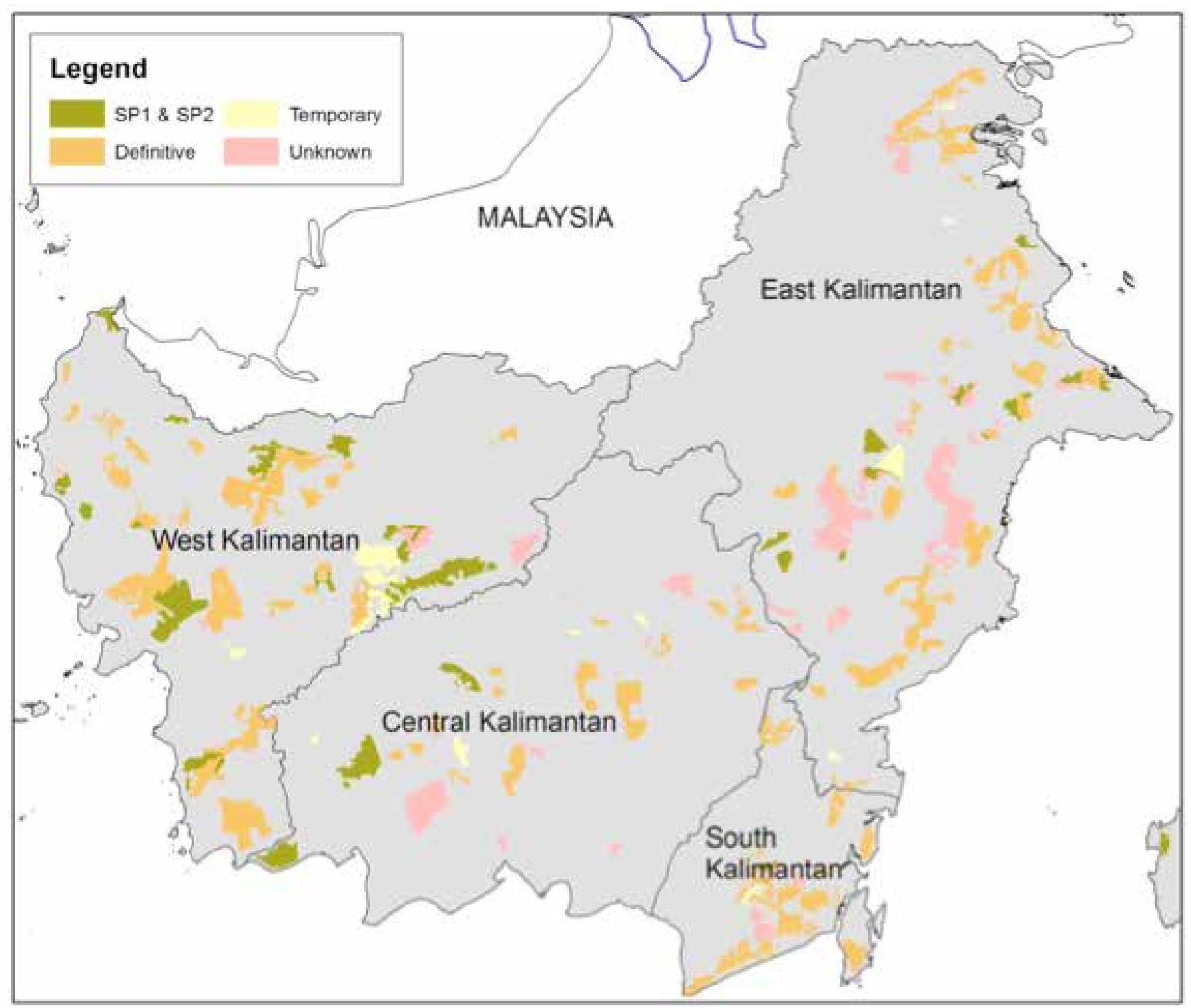

Note: SP1 refers to concessions that have reached the stage of preparing Environmental Impact Assessment (EIA) documents. SP2 are companies that have completed EIA and are preparing concession management plans.

Source: Authors 


\section{Appendix 7: Location of timber plantation licenses in Sumatra}

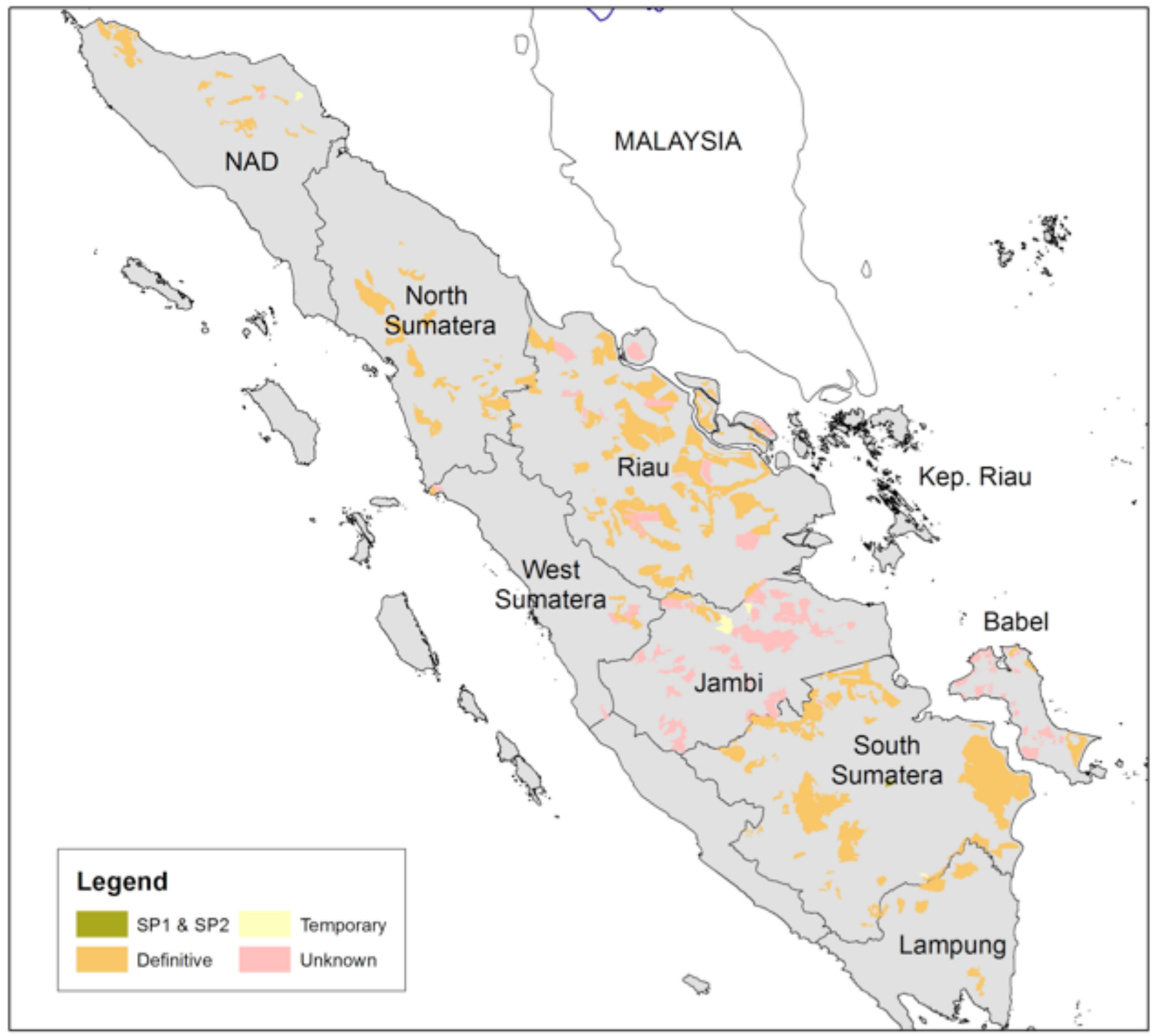

Note: SP1 refers to concessions that have reached the stage of preparing Environmental Impact Assessment (EIA) documents. SP2 are companies that have completed EIA and are preparing concession management plans.

Source: Authors 


\section{Appendix 8: Location of timber plantation licenses in Papua}

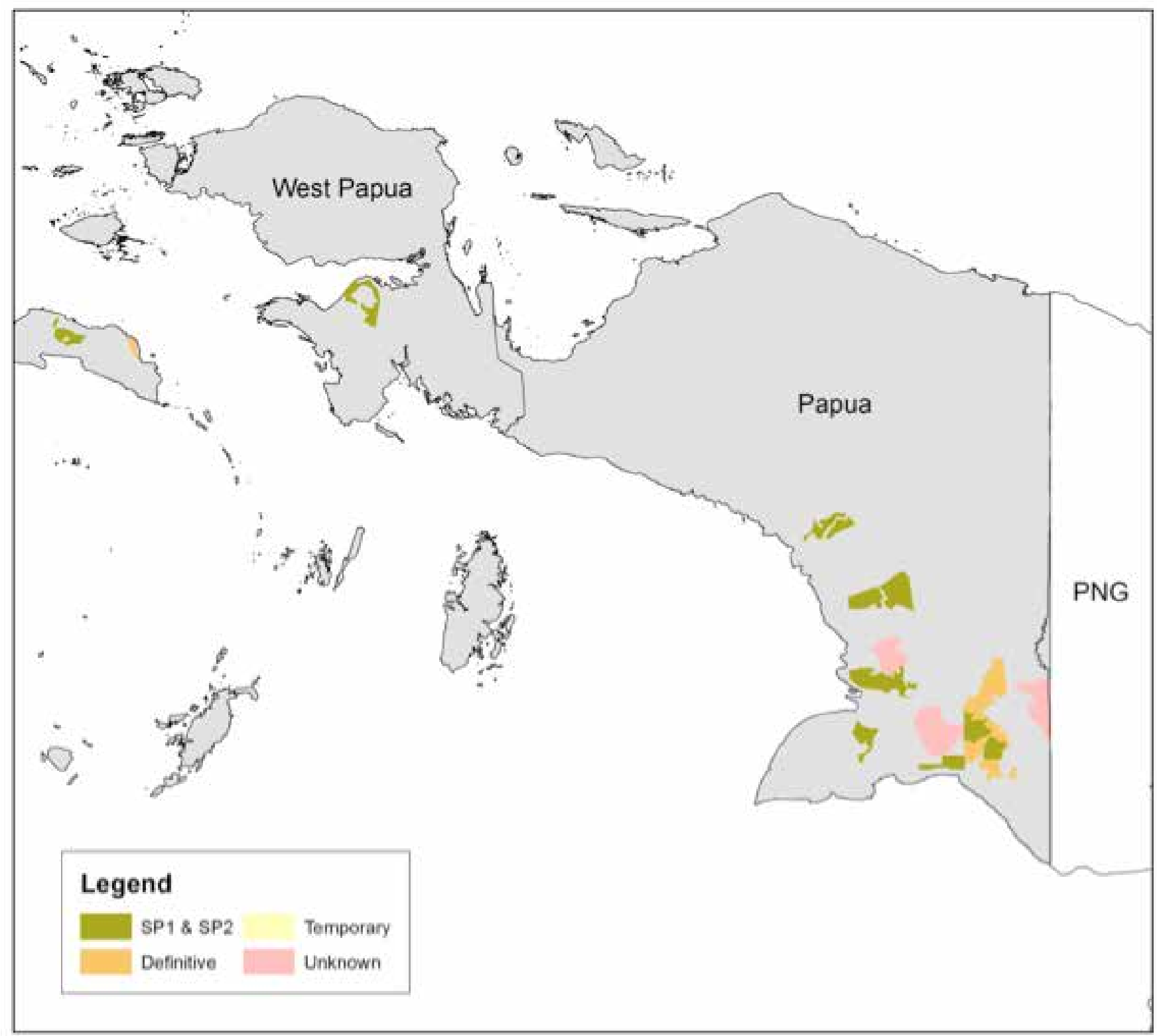

Note: SP1 refers to concessions that have reached the stage of preparing Environmental Impact Assessment (EIA) documents. SP2 are companies that have completed EIA and are preparing concession management plans.

Source: Authors 


\section{Appendix 9: Estimates of $\mathrm{CO}_{2}$ emissions related to drainage depth for different land use types}

\begin{tabular}{|c|c|c|c|c|c|c|}
\hline Authors & $\begin{array}{l}\text { Measurement } \\
\text { method }\end{array}$ & $\begin{array}{l}\text { Region } \\
\text { (country) }\end{array}$ & Land use & $\begin{array}{l}\text { Drainage } \\
\text { depth }(\mathrm{cm})\end{array}$ & $\begin{array}{l}\text { Drainage } \\
\text { duration }\end{array}$ & $\begin{array}{l}\mathrm{CO}_{2} \text { emissions } \\
\text { (tonnes/ha/year) }\end{array}$ \\
\hline \multirow[t]{3}{*}{$\begin{array}{l}\text { Agus et al. } \\
2010\end{array}$} & & \multirow[t]{3}{*}{$\begin{array}{l}\text { Nanggroe Aceh } \\
\text { Darussalam } \\
\text { (Indonesia) }\end{array}$} & $\begin{array}{l}\text { Oil palm } \\
\text { plantation } \\
\text { (1 year) }\end{array}$ & & & 40.9 \\
\hline & & & $\begin{array}{l}\text { Oil palm } \\
\text { plantation } \\
\text { (5 years) }\end{array}$ & & & 27.3 \\
\hline & & & $\begin{array}{l}\text { Oil palm } \\
\text { plantation } \\
\text { (10 years) }\end{array}$ & & & 32.9 \\
\hline \multirow{4}{*}{$\begin{array}{l}\text { Ali et al. } \\
2006\end{array}$} & \multirow{3}{*}{$\begin{array}{l}\text { Gas flux } \\
\text { measurement } \\
\text { with closed } \\
\text { chamber }\end{array}$} & \multirow{3}{*}{$\begin{array}{l}\text { Jambi } \\
\text { (Indonesia) }\end{array}$} & Logged forest & 25 & Variable & 36 \\
\hline & & & $\begin{array}{l}\text { Recently } \\
\text { burned and } \\
\text { cleared forest }\end{array}$ & 46 & Variable & 62 \\
\hline & & & $\begin{array}{l}\text { Settled } \\
\text { agriculture }\end{array}$ & 78 & Variable & 77 \\
\hline & $\begin{array}{l}\text { Gas flux } \\
\text { measurement } \\
\text { with closed } \\
\text { chamber }\end{array}$ & $\begin{array}{l}\text { Central } \\
\text { Kalimantan } \\
\text { (Indonesia) }\end{array}$ & $\begin{array}{l}\text { Rice fields at } 3 \\
\text { locations }\end{array}$ & 10 & & 4 \\
\hline \multirow{4}{*}{$\begin{array}{l}\text { Furukawa et } \\
\text { al. } 2005\end{array}$} & \multirow{4}{*}{$\begin{array}{l}\text { Gas flux } \\
\text { measurement } \\
\text { with closed } \\
\text { chamber }\end{array}$} & \multirow{4}{*}{$\begin{array}{l}\text { Jambi } \\
\text { (Indonesia) }\end{array}$} & Drained forest & 18 & Constant & 86 \\
\hline & & & Cassava field & 24 & Constant & 64 \\
\hline & & & $\begin{array}{l}\text { Upland paddy } \\
\text { field }\end{array}$ & 13 & Constant & 73 \\
\hline & & & $\begin{array}{l}\text { Lowland } \\
\text { paddy field }\end{array}$ & $\begin{array}{l}5 \text { above } \\
\text { ground } \\
\text { surface }\end{array}$ & & 10 \\
\hline \multirow[t]{5}{*}{$\begin{array}{l}\text { Hadi et al. } \\
2001\end{array}$} & \multirow{5}{*}{$\begin{array}{l}\text { Gas flux } \\
\text { measurement } \\
\text { with closed } \\
\text { chamber }\end{array}$} & \multirow{5}{*}{$\begin{array}{l}\text { South } \\
\text { Kalimantan } \\
\text { (Indonesia) }\end{array}$} & $\begin{array}{l}\text { Secondary } \\
\text { forest }\end{array}$ & 0 & Constant & 45 \\
\hline & & & Paddy field & 2 & Constant & 88 \\
\hline & & & $\begin{array}{l}\text { Secondary } \\
\text { forest }\end{array}$ & 38 & & 127 \\
\hline & & & Paddy field & 0 & & 51 \\
\hline & & & $\begin{array}{l}\text { Rice-soybean } \\
\text { rotation field }\end{array}$ & 0 & & 36 \\
\hline \multirow{3}{*}{$\begin{array}{l}\text { Inubushi } \\
\text { et al. 2003; } \\
\text { Inubushi et } \\
\text { al. } 2005\end{array}$} & \multirow{3}{*}{$\begin{array}{l}\text { Gas flux } \\
\text { measurement } \\
\text { with closed } \\
\text { chamber }\end{array}$} & \multirow[t]{3}{*}{$\begin{array}{l}\text { South } \\
\text { Kalimantan } \\
\text { (Indonesia) }\end{array}$} & $\begin{array}{l}\text { Abandoned } \\
\text { upland crops } \\
\text { field }\end{array}$ & 0 & & 36 \\
\hline & & & $\begin{array}{l}\text { Abandoned } \\
\text { paddy fields }\end{array}$ & 20 & & 56 \\
\hline & & & $\begin{array}{l}\text { Secondary } \\
\text { forest }\end{array}$ & 18 & & 44 \\
\hline
\end{tabular}


Appendix 9. Continued

\begin{tabular}{|c|c|c|c|c|c|c|}
\hline Authors & $\begin{array}{l}\text { Measurement } \\
\text { method }\end{array}$ & $\begin{array}{l}\text { Region } \\
\text { (country) }\end{array}$ & Land use & $\begin{array}{l}\text { Drainage } \\
\text { depth }(\mathrm{cm})\end{array}$ & $\begin{array}{l}\text { Drainage } \\
\text { duration }\end{array}$ & $\begin{array}{l}\mathrm{CO}_{2} \text { emissions } \\
\text { (tonnes/ha/year) }\end{array}$ \\
\hline \multirow{4}{*}{$\begin{array}{l}\text { Jauhiainen } \\
\text { et al. } 2005\end{array}$} & \multirow{4}{*}{$\begin{array}{l}\text { Gas flux } \\
\text { measurement } \\
\text { with closed } \\
\text { chamber } \\
\text { method }\end{array}$} & \multirow{4}{*}{$\begin{array}{l}\text { Sebangau River } \\
\text { catchment, } \\
\text { Kalimantan } \\
\text { (Indonesia) }\end{array}$} & \multirow{4}{*}{$\begin{array}{l}\text { Peat swamp } \\
\text { forest }\end{array}$} & Ave. 17 & \multirow[t]{4}{*}{ Variable } & \multirow[t]{4}{*}{35} \\
\hline & & & & Max. 24 & & \\
\hline & & & & Min. 75 & & \\
\hline & & & & Median 10 & & \\
\hline \multirow{17}{*}{$\begin{array}{l}\text { Jauhiainen } \\
\text { et al. } 2004\end{array}$} & \multirow{17}{*}{$\begin{array}{l}\text { Gas flux } \\
\text { measurement } \\
\text { with closed } \\
\text { chamber }\end{array}$} & \multirow{13}{*}{$\begin{array}{l}\text { Sebangau River } \\
\text { catchment, } \\
\text { Kalimantan } \\
\text { (Indonesia) }\end{array}$} & \multirow{4}{*}{$\begin{array}{l}\text { Selectively } \\
\text { logged forest }\end{array}$} & Ave. 21 & \multirow[t]{4}{*}{ Variable } & \multirow[t]{4}{*}{76} \\
\hline & & & & Max. 10 & & \\
\hline & & & & Min. 67 & & \\
\hline & & & & Median 15 & & \\
\hline & & & $\begin{array}{l}\text { Cleared } \\
\text { burned area } \\
\text { (high surface) }\end{array}$ & 19 & Variable & 23 \\
\hline & & & \multirow{4}{*}{$\begin{array}{l}\text { Cleared } \\
\text { burned area } \\
\text { (depression) }\end{array}$} & Ave. 1 & Variable & 28 \\
\hline & & & & Max. 46 & & \\
\hline & & & & Min. 49 & & \\
\hline & & & & Median 6 & & \\
\hline & & & \multirow{4}{*}{$\begin{array}{l}\text { Clear felled } \\
\text { but recovering } \\
\text { forest }\end{array}$} & Ave. 21 & Variable & 34 \\
\hline & & & & Max. 10 & & \\
\hline & & & & Min. 67 & & \\
\hline & & & & Median 15 & & \\
\hline & & \multirow{4}{*}{$\begin{array}{l}\text { Farm field, } \\
\text { Kalimantan } \\
\text { (Indonesia) }\end{array}$} & \multirow[t]{4}{*}{ Farm field } & Ave. 29 & & 19 \\
\hline & & & & Min. 72 & & \\
\hline & & & & Max. 5 & & \\
\hline & & & & Median 24 & & \\
\hline \multirow[t]{8}{*}{$\begin{array}{l}\text { Jauhiainen } \\
\text { et al. } 2001\end{array}$} & \multirow{8}{*}{$\begin{array}{l}\text { Gas flux } \\
\text { measurement } \\
\text { with closed } \\
\text { chamber }\end{array}$} & \multirow{8}{*}{$\begin{array}{l}\text { Central } \\
\text { Kalimantan } \\
\text { (Indonesia) }\end{array}$} & $\begin{array}{l}\text { Drained peat } \\
\text { and hollow }\end{array}$ & 0 & & 17 \\
\hline & & & Drained peat & 50 & & 26 \\
\hline & & & Hummock & 50 & & 43 \\
\hline & & & Hollow & 40 & & 52 \\
\hline & & & & 25 & & 25 \\
\hline & & & & 50 & & 35 \\
\hline & & & & 75 & & 36 \\
\hline & & & & 100 & & 29 \\
\hline $\begin{array}{l}\text { Jauhiainen } \\
\text { et al. } 2011\end{array}$ & $\begin{array}{l}\text { Gas flux } \\
\text { measurement } \\
\text { with closed } \\
\text { chamber }\end{array}$ & $\begin{array}{l}\text { Kampar } \\
\text { Peninsula, } \\
\text { Riau Province, } \\
\text { Sumatra } \\
\text { (Indonesia) }\end{array}$ & $\begin{array}{l}\text { Acacia } \\
\text { plantation } \\
\text { (8-10 years) }\end{array}$ & 80 & & 102.5 \\
\hline
\end{tabular}


Appendix 9. Continued

\begin{tabular}{|c|c|c|c|c|c|c|}
\hline Authors & $\begin{array}{l}\text { Measurement } \\
\text { method }\end{array}$ & $\begin{array}{l}\text { Region } \\
\text { (country) }\end{array}$ & Land use & $\begin{array}{l}\text { Drainage } \\
\text { depth }(\mathrm{cm})\end{array}$ & $\begin{array}{l}\text { Drainage } \\
\text { duration }\end{array}$ & $\begin{array}{l}\mathrm{CO}_{2} \text { emissions } \\
\text { (tonnes/ha/year) }\end{array}$ \\
\hline \multirow[t]{5}{*}{$\begin{array}{l}\text { Hooijer et al. } \\
2010\end{array}$} & \multirow{2}{*}{$\begin{array}{l}\text { 1] } \mathrm{CO}_{2} \text { emission } \\
=\mathrm{LU} \text { Area·D } \\
\text { Area·D } \\
\text { Depth·CO } 1 \mathrm{~m} \\
\text { [t/y] Where: } \\
\text { LU Area = } \\
\text { peatland area } \\
\text { with specific } \\
\text { land use [ha] }\end{array}$} & $\begin{array}{l}\text { Kalimantan, } \\
\text { Sumatra } \\
\text { and Papua } \\
\text { (Indonesia) }\end{array}$ & $\begin{array}{l}\text { Estate crop } \\
\text { plantations }\end{array}$ & $95 \mathrm{~cm}$ & & 86 \\
\hline & & $\begin{array}{l}\text { Kalimantan, } \\
\text { Sumatra } \\
\text { and Papua } \\
\text { (Indonesia) }\end{array}$ & $\begin{array}{l}\text { Small-scale } \\
\text { agriculture, } \\
\text { mixed } \\
\text { cropland and } \\
\text { shrub land }\end{array}$ & 60 & & 48 \\
\hline & $\begin{array}{l}\text { D Area = } \\
\text { drained area } \\
\text { within peatland } \\
\text { area with } \\
\text { specific land } \\
\text { use [fraction] }\end{array}$ & \multirow[t]{3}{*}{$\begin{array}{l}\text { Kalimantan, } \\
\text { Sumatra } \\
\text { and Papua } \\
\text { (Indonesia) }\end{array}$} & \multirow[t]{3}{*}{ Shrub land } & \multirow[t]{3}{*}{33} & & \multirow[t]{3}{*}{15} \\
\hline & $\begin{array}{l}\text { D Depth } \\
=\text { average } \\
\text { groundwater } \\
\text { depth in } \\
\text { drained } \\
\text { peatland area } \\
\text { with specific } \\
\text { land use [m] }\end{array}$ & & & & & \\
\hline & $\begin{array}{l}\mathrm{CO}_{2} 1 \mathrm{~m}=\mathrm{CO}_{2} \\
\text { emission at } \\
\text { an average } \\
\text { groundwater } \\
\text { depth of } 1 \mathrm{~m}= \\
91\left[\mathrm{tCO}_{2} \mathrm{ha}^{-1} \mathrm{y}^{-}\right]\end{array}$ & & & & & \\
\hline $\begin{array}{l}\text { Hooijer et al. } \\
2012\end{array}$ & & $\begin{array}{l}\text { Central } \\
\text { Kalimantan } \\
\text { (Indonesia) }\end{array}$ & Plantation & 70 & & $86-100$ \\
\hline \multirow{3}{*}{$\begin{array}{l}\text { Melling et al. } \\
2005\end{array}$} & \multirow{3}{*}{$\begin{array}{l}\text { Gas flux } \\
\text { measurement } \\
\text { with closed } \\
\text { chamber }\end{array}$} & \multirow{3}{*}{$\begin{array}{l}\text { Sarawak } \\
\text { (Malaysia) }\end{array}$} & Forest & 45 & Variable & 77 \\
\hline & & & Oil palm & 60 & Variable & 77 \\
\hline & & & Sago & 60 & Variable & 55 \\
\hline $\begin{array}{l}\text { Melling et al. } \\
2007\end{array}$ & $\begin{array}{l}\text { Gas flux } \\
\text { measurement } \\
\text { with closed } \\
\text { chamber }\end{array}$ & $\begin{array}{l}\text { Sarawak } \\
\text { (Malaysia) }\end{array}$ & $\begin{array}{l}\text { Oil palm } \\
\text { (5 years) }\end{array}$ & & & 56.5 \\
\hline \multirow{5}{*}{$\begin{array}{l}\text { Murayama } \\
\text { and Bakar } \\
1996\end{array}$} & \multirow{5}{*}{$\begin{array}{l}\text { Gas flux } \\
\text { measurement } \\
\text { with closed } \\
\text { chamber }\end{array}$} & \multirow{4}{*}{$\begin{array}{l}\text { Western Johore } \\
\text { (Malaysia) }\end{array}$} & Forest & 50 & & 39 \\
\hline & & & Oil palm & 80 & & 54 \\
\hline & & & $\begin{array}{l}\text { Pineapple } \\
\text { field }\end{array}$ & 40 & & 30 \\
\hline & & & Maize field & 40 & & 29 \\
\hline & & $\begin{array}{l}\text { Central Selangor } \\
\text { (Malaysia) }\end{array}$ & Fallow peat & 30 & & 22 \\
\hline \multirow{2}{*}{$\begin{array}{l}\text { Page et al. } \\
2011\end{array}$} & & \multirow[t]{2}{*}{ Indonesia } & \multirow{2}{*}{$\begin{array}{l}\text { Oil palm } \\
\text { plantation }\end{array}$} & \multirow[t]{2}{*}{$60-85$} & & 86 over 50 years \\
\hline & & & & & & 100 over 25 years \\
\hline
\end{tabular}


Appendix 9. Continued

\begin{tabular}{lllllll}
\hline Authors & $\begin{array}{l}\text { Measurement } \\
\text { method }\end{array}$ & $\begin{array}{l}\text { Region } \\
\text { (country) }\end{array}$ & Land use & $\begin{array}{l}\text { Drainage } \\
\text { depth }(\mathbf{c m})\end{array}$ & $\begin{array}{l}\text { Drainage } \\
\text { duration }\end{array}$ & $\begin{array}{l}\mathrm{CO}_{2} \text { emissions } \\
\text { (tonnes/ha/year) }\end{array}$ \\
\hline $\begin{array}{l}\text { Gas flux } \\
\text { measurement } \\
\text { with closed } \\
\text { chamber }\end{array}$ & $\begin{array}{l}\text { Central Selangor } \\
\text { (Malaysia) }\end{array}$ & Forest & 70 & 54 \\
\cline { 2 - 6 } (Thailand) & Forest & 70 & 54 \\
\hline $\begin{array}{l}\text { Wösten et al. } \\
1997\end{array}$ & $\begin{array}{l}\text { Measurements } \\
\text { of subsidence } \\
\text { and soil } \\
\text { characteristics }\end{array}$ & $\begin{array}{l}\text { Kalimantan } \\
\text { (Indonesia) }\end{array}$ & Plantation & 50 & 65 \\
\cline { 3 - 5 } & & 70 & 100 & 130 \\
\hline
\end{tabular}

Sources: Adapted from Hooijer et al. (2006) and Page et al. (2011). 


\section{Appendix 10: Companies certified by the Roundtable on Sustainable Palm Oil in Indonesia, 2012}

\begin{tabular}{|c|c|c|c|c|c|}
\hline Name of company & Certified units/facilities & Location & Group & $\begin{array}{l}\text { Area cert. } \\
\text { (ha) }\end{array}$ & $\begin{array}{l}\text { CPO ton } \\
\text { cert. }\end{array}$ \\
\hline PT Aek Tarum & 3 estates and 1 palm oil mill & $\begin{array}{l}\text { Kabupaten Ogan } \\
\text { Komering Ilir, South } \\
\text { Sumatra }\end{array}$ & $\begin{array}{l}\text { Sampoerna } \\
\text { Agro }\end{array}$ & 5,392 & 20,937 \\
\hline PT Agro Indomas & 3 estates and 1 palm oil mill & $\begin{array}{l}\text { Pangkalan Bun, } \\
\text { Central Kalimantan }\end{array}$ & GoodHope & 9,602 & 6,729 \\
\hline PT Agro Muko & $\begin{array}{l}8 \text { estates and } 8 \text { palm oil } \\
\text { mills }\end{array}$ & & Sipef & 18,280 & 79,000 \\
\hline PT Agrowiratama & 6 estates and 1 palm oil mill & $\begin{array}{l}\text { Pasaman Barat, West } \\
\text { Sumatra }\end{array}$ & Musim Mas & 7,512 & 4,538 \\
\hline $\begin{array}{l}\text { PT Bakrie Sumatera } \\
\text { Plantation Tbk }\end{array}$ & 5 estates and 1 palm oil mill & $\begin{array}{l}\text { Asahan, North } \\
\text { Sumatra }\end{array}$ & Bakrie & 7,197 & 36,438 \\
\hline PT Berkat Sawit Sejati & 2 estates and 1 palm oil mill & $\begin{array}{l}\text { Musi Banyuasin, } \\
\text { South Sumatra }\end{array}$ & Musim Mas & 10,862 & 54,166 \\
\hline $\begin{array}{l}\text { PT Bersama Sejahtera } \\
\text { Sakti }\end{array}$ & 4 estates and 1 palm oil mill & $\begin{array}{l}\text { Kota Baru, } \\
\text { Kalimantan }\end{array}$ & Sime Darby & 12,512 & 55,839 \\
\hline $\begin{array}{l}\text { PT Buana Wiralestari } \\
\text { Mas }\end{array}$ & 1 estate and 1 palm oil mill & Kampar, Riau & Sinar Mas & 8,148 & 20,726 \\
\hline $\begin{array}{l}\text { PT Bulu Cawang } \\
\text { Plantation }\end{array}$ & 2 estates and 1 palm oil mill & $\begin{array}{l}\text { Ogan Komering llir, } \\
\text { South Sumatra }\end{array}$ & Wilmar & 5,831 & 32,939 \\
\hline $\begin{array}{l}\text { PT First Mujur } \\
\text { Plantation and } \\
\text { Industry }\end{array}$ & 3 estates and 1 palm oil mill & $\begin{array}{l}\text { Kab. Padang } \\
\text { LawasUtara, North } \\
\text { Sumatra }\end{array}$ & & 13,193 & 61,107 \\
\hline PT Hindoli & smallholder estates & South Sumatra & Cargill & 17,594 & 51,344 \\
\hline PT Hindoli & estates and palm oil mill & South Sumatra & Cargill & & 135,548 \\
\hline PT Indrotruba Tengah & 2 estates and 1 palm oil mill & $\begin{array}{l}\text { Kotawaringin Barat, } \\
\text { Central Kalimantan }\end{array}$ & Gozco & 7,735 & 38,879 \\
\hline PT Inti Indosawit Subur & 1 estate and 1 palm oil mill & Tungkal Ulu, Jambi & Asian Agri & 4,396 & 60,635 \\
\hline PT Inti Indosawit Subur & smallholder estates & Pelalawan, Riau & Asian Agri & 13,536 & 54,282 \\
\hline PT Inti Indosawit Subur & 2 palm oil mills & $\begin{array}{l}\text { Tungkal Ulu and } \\
\text { Muara Bulian, Jambi }\end{array}$ & Asian Agri & & 127,301 \\
\hline $\begin{array}{l}\text { PT Kerry Sawit } \\
\text { Indonesia }\end{array}$ & 3 estates and 1 palm oil mill & $\begin{array}{l}\text { Kab. Seruyan, } \\
\text { Central }\end{array}$ & Wilmar & 15,614 & 51,656 \\
\hline PT Kridatama Lancar & 4 estates and 1 palm oil mill & $\begin{array}{l}\text { Kotawaringin Timur, } \\
\text { Central Kalimantan }\end{array}$ & Sime Darby & 13,307 & 50,286 \\
\hline
\end{tabular}


Appendix 10a. Continued

\begin{tabular}{|c|c|c|c|c|c|}
\hline Name of company & Certified units/facilities & Location & Group & $\begin{array}{l}\text { Area cert. } \\
\text { (ha) }\end{array}$ & $\begin{array}{l}\text { CPO ton } \\
\text { cert. }\end{array}$ \\
\hline $\begin{array}{l}\text { PT Ladang Rumpun } \\
\text { Suburabadi }\end{array}$ & 2 estates and 1 palm oil mill & $\begin{array}{l}\text { Tanah Bumbu, South } \\
\text { Kalimantan }\end{array}$ & Sime Darby & 5,604 & 25,789 \\
\hline PT Musim Mas & $\begin{array}{l}6 \text { estates and } 2 \text { palm oil } \\
\text { mills and Koperasi Kredit } \\
\text { Primer untuk Anggota } \\
\text { (KKPA) Desaa }\end{array}$ & Dumai, Riau & Musim Mas & 25,918 & 152,310 \\
\hline PT Mustika Sembuluh & estates and palm oil mill & South Sumatera & Wilmar & 5,831 & 32,838 \\
\hline PT Mustika Sembuluh & 3 estates and 1 palm oil mill & $\begin{array}{l}\text { Kotawaringin Timur } \\
\text { and Seruayan, } \\
\text { Central Kalimantan }\end{array}$ & Wilmar & 15,604 & 79,860 \\
\hline PT Perkebunan Milano & 3 estates and 1 palm oil mill & $\begin{array}{l}\text { Labuhan Batu, North } \\
\text { Sumatra }\end{array}$ & Wilmar & 4,943 & 27,554 \\
\hline $\begin{array}{l}\text { PT Perkebunan } \\
\text { Nusantara III (Persero) }\end{array}$ & estates and palm oil mill & North Sumatra & $\begin{array}{l}\text { state- } \\
\text { owned } \\
\text { company }\end{array}$ & 26,479 & 74,708 \\
\hline $\begin{array}{l}\text { PT Perkebunan } \\
\text { Nusantara IV (Persero) }\end{array}$ & 1 estate and 1 palm oil mill & $\begin{array}{l}\text { Simalungun, North } \\
\text { Sumatra }\end{array}$ & $\begin{array}{l}\text { state- } \\
\text { owned } \\
\text { company }\end{array}$ & 10,554 & 24,201 \\
\hline $\begin{array}{l}\text { PT PP London } \\
\text { Sumatera Indonesia } \\
\text { Tbk }\end{array}$ & $\begin{array}{l}12 \text { estates and } 4 \text { palm oil } \\
\text { mills }\end{array}$ & North Sumatra & Indoagri & 34,377 & 159,480 \\
\hline $\begin{array}{l}\text { PT PP London } \\
\text { Sumatera Indonesia } \\
\text { Tbk }\end{array}$ & 3 estates and 1 palm oil mill & $\begin{array}{l}\text { Musi Banyuasin, } \\
\text { South Sumatra }\end{array}$ & Indoagri & 10,031 & 32,164 \\
\hline PT Ramajaya Pramukti & 1 estate and 1 palm oil mill & Kampar, Riau & Sinar Mas & 10,614 & 30,744 \\
\hline $\begin{array}{l}\text { PT REA Kaltim } \\
\text { Plantation }\end{array}$ & $\begin{array}{l}6 \text { estates and } 2 \text { palm oil } \\
\text { mills }\end{array}$ & East Kalimantan & $\begin{array}{l}\text { R.E.A. } \\
\text { Holdings }\end{array}$ & 22,943 & 127,256 \\
\hline $\begin{array}{l}\text { PT Sahabat Mewah } \\
\text { dan Makmur }\end{array}$ & 5 estates and 1 palm oil mill & Bangka & ANJ Agri & 15,873 & 65,518 \\
\hline PT Sajang Heulang & 2 estates and 1 palm oil mill & $\begin{array}{l}\text { Tanah Bumbu, South } \\
\text { Kalimantan }\end{array}$ & Sime Darby & 6,510 & 22,227 \\
\hline $\begin{array}{l}\text { PT Salim Ivomas } \\
\text { Pratama Tbk }\end{array}$ & 2 estates and 1 palm oil mill & Rokan Hilir, Riau & Indoagri & 10,373 & 53,400 \\
\hline PT Smart Tbk & estates and palm oil mill & $\begin{array}{l}\text { Labuhan Batu, North } \\
\text { Sumatra }\end{array}$ & Sinar Mas & 14,955 & 83,759 \\
\hline PT Socfin Indonesia & 1 estate and 1 palm oil mill & $\begin{array}{l}\text { Serdang Bedagai, } \\
\text { North Sumatra }\end{array}$ & Socfinasia & 2,918 & 12,722 \\
\hline $\begin{array}{l}\text { PT Sukajadi Sawit } \\
\text { Mekar }\end{array}$ & 3 estates and 1 palm oil mill & $\begin{array}{l}\text { Kotawaringin Timur, } \\
\text { Central Kalimantan }\end{array}$ & Musim Mas & 16,111 & 99,109 \\
\hline PT Teguh Sempurna & 4 estates and 1 palm oil mill & $\begin{array}{l}\text { Kotawaringin Timur, } \\
\text { Central Kalimantan }\end{array}$ & Sime Darby & 13,816 & 41,974 \\
\hline PT Tolan Tiga Indonesia & 4 estates and 1 palm oil mill & North Sumatra & Sipef & 13,691 & 78,000 \\
\hline TOTAL & & & & $427,252,614$ & $2,154,696$ \\
\hline
\end{tabular}

a $\mathrm{KKPA}=$ Koperasi Kredit Primer Anggota, Prime Cooperative Credit for Members. 
Principles and criteria assessment notification

\begin{tabular}{|c|c|c|c|c|c|}
\hline Name of company & Certified units/facilities & Location & Group & $\begin{array}{l}\text { Area } \\
\text { certified }\end{array}$ & $\begin{array}{l}\text { CPO ton } \\
\text { cert. }\end{array}$ \\
\hline PT Adei Plantation & 7 estates and 1 palm oil mill & Bengkalis, Riau & $\begin{array}{l}\text { KL } \\
\text { Kepong }\end{array}$ & 7,563 & 47 \\
\hline PT AMP Plantation & 1 estates and 1 palm oil mill & Agam, West Sumatra & Wilmar & 7,517 & 37.002 \\
\hline PT Aneka Inti Perkasa & 3 estates and 1 palm oil mill & Siak, Riau & $\begin{array}{l}\text { Sime } \\
\text { Darby }\end{array}$ & 9,836 & 50.542 \\
\hline PT Bahari Gembira Ria & 2 estates and 1 palm oil mill & Muaro Jambi, Jambi & $\begin{array}{l}\text { Sime } \\
\text { Darby }\end{array}$ & 2.909 & 8.167 \\
\hline $\begin{array}{l}\text { PT Bhumireksa Nusa } \\
\text { Sejati }\end{array}$ & 5 estates and 1 palm oil mill & Indragiri Hilir, Riau & $\begin{array}{l}\text { Sime } \\
\text { Darby }\end{array}$ & 18.717 & 73.444 \\
\hline $\begin{array}{l}\text { PT Bina Sains } \\
\text { Cemerlang }\end{array}$ & 2 estates and 1 palm oil mill & $\begin{array}{l}\text { Musi Rawas, South } \\
\text { Sumatra }\end{array}$ & $\begin{array}{l}\text { Sime } \\
\text { Darby }\end{array}$ & 6.41 & 30.033 \\
\hline $\begin{array}{l}\text { PT Guthrie Pecconina } \\
\text { Indonesia }\end{array}$ & 5 estates and 1 palm oil mill & $\begin{array}{l}\text { Musi Banyuasin, } \\
\text { South Sumatra }\end{array}$ & $\begin{array}{l}\text { Sime } \\
\text { Darby }\end{array}$ & 10.539 & 27.163 \\
\hline PT Laguna Mandiri & 4 estates and 2 palm oil mills & $\begin{array}{l}\text { Kota Baru, South } \\
\text { Kalimantan }\end{array}$ & Wilmar & 12.875 & 41.343 \\
\hline PT Lahan Tani Sakti & 1 estate and 1 palm oil mill & Rokan Hilir, Riau & $\begin{array}{l}\text { Sime } \\
\text { Darby }\end{array}$ & 3.184 & 10.866 \\
\hline $\begin{array}{l}\text { PT Langgeng } \\
\text { Muaramakmur }\end{array}$ & 10 estates and 1 palm oil mill & $\begin{array}{l}\text { Kota Baru, South } \\
\text { Kalimantan }\end{array}$ & $\begin{array}{l}\text { Sime } \\
\text { Darby }\end{array}$ & 10.794 & 58.709 \\
\hline PT Maju Aneka Sawit & 2 estates and 1 palm oil mill & $\begin{array}{l}\text { Kotawaringin Timur, } \\
\text { Central Kalimantan }\end{array}$ & $\begin{array}{l}\text { Musim } \\
\text { Mas }\end{array}$ & 8.028 & 41.217 \\
\hline PT Mentari Pratama & 1 estates and 1 palm oil mill & $\begin{array}{l}\text { Ketapang, West } \\
\text { Kalimantan }\end{array}$ & $\begin{array}{l}\text { Musim } \\
\text { Mas }\end{array}$ & 3.954 & \\
\hline $\begin{array}{l}\text { PT Mitra Austral } \\
\text { Sejahtera }\end{array}$ & 3 estates and 1 palm oil mill & $\begin{array}{l}\text { Sanggau, West } \\
\text { Kalimantan }\end{array}$ & $\begin{array}{l}\text { Sime } \\
\text { Darby }\end{array}$ & 8.003 & 21.43 \\
\hline $\begin{array}{l}\text { PT Padang Palma } \\
\text { Permai }\end{array}$ & 2 estates and 1 palm oil mill & $\begin{array}{l}\text { Aceh Tamiang, } \\
\text { Nanggroe Aceh } \\
\text { Darussalam }\end{array}$ & $\begin{array}{l}\text { Sime } \\
\text { Darby }\end{array}$ & 2.063 & 6.189 \\
\hline PT Paripurna Swakarsa & 4 estates and 2 palm oil mills & $\begin{array}{l}\text { Kota Baru, South } \\
\text { Kalimantan }\end{array}$ & $\begin{array}{l}\text { Sime } \\
\text { Darby }\end{array}$ & 15.039 & 66.921 \\
\hline PT Perkasa Subur Sakti & 2 estates and 1 palm oil mill & $\begin{array}{l}\text { Aceh Timur, } \\
\text { Nanggroe Aceh } \\
\text { Darussalam }\end{array}$ & $\begin{array}{l}\text { Sime } \\
\text { Darby }\end{array}$ & 4.467 & 6.112 \\
\hline $\begin{array}{l}\text { PT Primatama Mulia } \\
\text { Jaya }\end{array}$ & & $\begin{array}{l}\text { Pasaman Barat, West } \\
\text { Sumatra }\end{array}$ & Wilmar & 1.391 & \\
\hline PT Sandika Natapalma & 5 estates and 1 palm oil mill & $\begin{array}{l}\text { Ketapang, West } \\
\text { Kalimantan }\end{array}$ & $\begin{array}{l}\text { Sime } \\
\text { Darby }\end{array}$ & 9.516 & 37.593 \\
\hline $\begin{array}{l}\text { PT Sarana Titian } \\
\text { Permata }\end{array}$ & 3 estates & $\begin{array}{l}\text { Seruyan, Central } \\
\text { Kalimantan }\end{array}$ & Wilmar & 19.979 & 44.671 \\
\hline $\begin{array}{l}\text { PT Sawit Sumbermas } \\
\text { Sarana }\end{array}$ & 8 estates and 1 palm oil mill & $\begin{array}{l}\text { Kotawaringin Barat, } \\
\text { Central Kalimantan }\end{array}$ & $\begin{array}{l}\text { Citra } \\
\text { Borneo } \\
\text { Indah }\end{array}$ & 19.027 & 116.09 \\
\hline PT Sime Indo Agro & $\begin{array}{l}3 \text { estates and smallholder } \\
\text { estates }\end{array}$ & $\begin{array}{l}\text { Sanggau, West } \\
\text { Kalimantan }\end{array}$ & $\begin{array}{l}\text { Sime } \\
\text { Darby }\end{array}$ & 7.154 & 33.609 \\
\hline PT Swadaya Andika & 4 estates and 1 palm oil mill & $\begin{array}{l}\text { Kota Baru, South } \\
\text { Kalimantan }\end{array}$ & $\begin{array}{l}\text { Sime } \\
\text { Darby }\end{array}$ & 14.48 & 29.724 \\
\hline
\end{tabular}


Appendix 10b. Continued

\begin{tabular}{|c|c|c|c|c|c|}
\hline Name of company & Certified units/facilities & Location & Group & $\begin{array}{l}\text { Area } \\
\text { certified }\end{array}$ & $\begin{array}{l}\text { CPO ton } \\
\text { cert. }\end{array}$ \\
\hline $\begin{array}{l}\text { PT Swakarsa Sinar } \\
\text { Sentosa }\end{array}$ & 4 estates and 1 palm oil mill & $\begin{array}{l}\text { Muara Wahau, East } \\
\text { Kalimantan }\end{array}$ & Swakarsa & 15.219 & 75 \\
\hline PT Tamaco Graha Krida & 1 estate and 1 palm oil mill & $\begin{array}{l}\text { Morowali, Central } \\
\text { Sulawesi }\end{array}$ & $\begin{array}{l}\text { Sime } \\
\text { Darby }\end{array}$ & 4.255 & 22.025 \\
\hline PT Tania Selatan & 2 estates and 1 palm oil mill & OKI, South Sumatra & Wilmar & 3.685 & 13.567 \\
\hline $\begin{array}{l}\text { PT Tunggal Mitra } \\
\text { Plantation }\end{array}$ & 3 estates and 1 palm oil mill & Rokan Hilir, Riau & $\begin{array}{l}\text { Sime } \\
\text { Darby }\end{array}$ & 10.849 & 54.89 \\
\hline PT Unggul Lestari & 2 estates and 1 palm oil mill & $\begin{array}{l}\text { Kotawaringin Timur, } \\
\text { Central Kalimantan }\end{array}$ & $\begin{array}{l}\text { Musim } \\
\text { Mas }\end{array}$ & 10.837 & 54.161 \\
\hline
\end{tabular}

Sources: RSPO (www.rspo.org); BSI Group Singapure Pte Ltd (www.bsigroup.com); PT SAI Global Indonesia (www.saiglobal.com); PT Mutuagung Lestari (www.mutucertification.com); PT TUV NORD Indonesia (www.tuv-nord.co.id). 


\section{Appendix 11: Roundtable on Sustainable Palm Oil principles and criteria}

Principle 1. Commitment to transparency

- Criterion 1.1: Growers and millers provide adequate information to relevant stakeholders on environmental, social and legal issues relevant to RSPO Criteria, in appropriate languages and forms to allow for effective participation in decision making.

- Criterion 1.2: Management documents are publicly available, except where this is prevented by commercial confidentiality or where disclosure of information would result in negative environmental or social outcomes.

- Criterion 1.3: Growers and millers commit to ethical conduct in all business operations and transactions.

\section{Principle 2. Compliance with applicable laws and regulations}

- Criterion 2.1: There is compliance with all applicable local, national and ratified international laws and regulations.

- Criterion 2.2: The right to use the land is demonstrated, and is not legitimately contested by local people who can demonstrate that they have legal, customary or user rights.

- Criterion 2.3: Use of the land for oil palm does not diminish the legal, customary or user rights of other users without their free, prior and informed consent.

Principle 3. Commitment to long-term economic and financial viability

- Criterion 3.1: There is an implemented management plan that aims to achieve longterm economic and financial viability.

\section{Principle 4. Use of appropriate best practices by growers and millers}

- Criterion 4.1: Operating procedures are appropriately documented, consistently implemented and monitored.

- Criterion 4.2: Practices maintain soil fertility at, or where possible improve soil fertility to, a level that ensures optimal and sustained yield.

- Criterion 4.3: Practices minimize and control erosion and degradation of soils.
- Criterion 4.4: Practices maintain the quality and availability of surface and ground water.

- Criterion 4.5: Pests, diseases, weeds and invasive introduced species are effectively managed using appropriate Integrated Pest Management techniques.

- Criterion 4.6: Pesticides are used in ways that do not endanger health or the environment.

- Criterion 4.7: An occupational health and safety plan is documented, effectively communicated and implemented.

- Criterion 4.8: All staff, workers, smallholders and contract workers are appropriately trained.

\section{Principle 5: Environmental responsibility and conservation of natural resources and} biodiversity

- Criterion 5.1: Aspects of plantation and mill management, including replanting, that have environmental impacts are identified, and plans to mitigate the negative impacts and promote the positive ones are made, implemented and monitored, to demonstrate continual improvement.

- Criterion 5.2: The status of rare, threatened or endangered species and other High Conservation Value habitats, if any, that exist in the plantation or that could be affected by plantation or mill management, shall be identified and operations managed to best ensure that they are maintained and/or enhanced.

- Criterion 5.3: Waste is reduced, recycled, reused and disposed of in an environmentally and socially responsible manner.

- Criterion 5.4: Efficiency of fossil fuel use and the use of renewable energy is optimized.

- Criterion 5.5: Use of fire for preparing land or replanting is avoided, except in specific situations as identified in the ASEAN guidelines or other regional best practice.

- Criterion 5.6: Plans to reduce pollution and emissions, including greenhouse gases, are developed, implemented and monitored. 


\section{Principle 6. Responsible consideration of employees and of individuals and communities affected by growers and mills}

- Criterion 6.1: Aspects of plantation and mill management that have social impacts, including replanting, are identified in a participatory way, and plans to mitigate the negative impacts and promote the positive ones are made, implemented and monitored, to demonstrate continual improvement.

- Criterion 6.2: There are open and transparent methods for communication and consultation between growers and/or millers, local communities and other affected or interested parties.

- Criterion 6.3: There is a mutually agreed and documented system for dealing with complaints and grievances, which is implemented and accepted by all affected parties.

- Criterion 6.4: Any negotiations concerning compensation for loss of legal, customary or user rights are dealt with through a documented system that enables indigenous peoples, local communities and other stakeholders to express their views through their own representative institutions.

- Criterion 6.5: Pay and conditions for employees and for contract workers always meet at least legal or industry minimum standards and are sufficient to provide decent living wages.

- Criterion 6.6: The employer respects the rights of all personnel to form and join trade unions of their choice and to bargain collectively. Where the right to freedom of association and collective bargaining are restricted under law, the employer facilitates parallel means of independent and free association and bargaining for all such personnel.

- Criterion 6.7: Children are not employed or exploited.

- Criterion 6.8: Any form of discrimination based on race, caste, national origin, religion, disability, gender, sexual orientation, union membership, political affiliation, or age, is prohibited.

- Criterion 6.9: There is no harassment or abuse in the work place, and reproductive rights are protected.

- Criterion 6.10: Growers and millers deal fairly and transparently with smallholders and other local businesses.

- Criterion 6.11: Growers and millers contribute to local sustainable development where appropriate.
- Criterion 6.12: No forms of forced or trafficked labor are used.

- Criterion 6.13: Growers and millers respect human rights.

\section{Principle 7. Responsible development of new plantings}

- Criterion 7.1: A comprehensive and participatory independent social and environmental impact assessment is undertaken prior to establishing new plantings or operations, or expanding existing ones, and the results incorporated into planning, management and operations.

- Criterion 7.2: Soil surveys and topographic information are used for site planning in the establishment of new plantings, and the results are incorporated into plans and operations.

- Criterion 7.3: New plantings since November 2005 have not replaced primary forest or any area required to maintain or enhance one or more High Conservation Values.

- Criterion 7.4: Extensive planting on steep terrain, and/or marginal and fragile soils, including peat, is avoided.

- Criterion 7.5: No new plantings are established on local peoples' land where it can be demonstrated that there are legal, customary or user rights, without their free, prior and informed consent. This is dealt with through a documented system that enables these and other stakeholders to express their views through their own representative institutions.

- Criterion 7.6: Where it can be demonstrated that local peoples have legal, customary or user rights, they are compensated for any agreed land acquisitions and relinquishment of rights, subject to their free, prior and informed consent and negotiated agreements.

- Criterion 7.7: No use of fire in the preparation of new plantings other than in specific situations, as identified in the ASEAN guidelines or other regional best practice.

- Criterion 7.8: New plantation developments are designed to minimize net greenhouse gas emissions.

\section{Principle 8: Commitment to continuous improvement in key areas of activity}

- Criterion 8.1: Growers and millers regularly monitor and review their activities, and develop and implement action plans that allow demonstrable continual improvement in key operations. 


\title{
Appendix 12: Roundtable on Sustainable Biomaterials principles and criteria
}

\author{
Version 2.0 November 2010
}

\author{
Principle 1. Biofuel operations shall follow all \\ applicable laws and regulations. \\ - Criterion 1a: Biofuel operations shall comply \\ with all applicable laws and regulations.
}

Principle 2. Sustainable biofuel operations shall be planned, implemented and continuously improved through an open, transparent, and consultative impact assessment and management process and an economic viability analysis.

- Criterion 2a: Biofuel operations shall undertake an impact assessment process to assess impacts and risks and ensure sustainability through the development of effective and efficient implementation, mitigation, monitoring and evaluation plans.

- Criterion 2b: Free, prior and informed consent (FPIC) shall form the basis for the process to be followed during all stakeholder consultations, which shall be gender sensitive and result in consensus driven negotiated agreements.

- Criterion 2c: Biofuel operators shall implement a business plan that reflects a commitment to long-term economic viability.

Principle 3. Biofuels shall contribute to climate change mitigation by significantly reducing lifecycle GHG emissions as compared to fossil fuels.

- Criterion 3a: In geographic areas with legislative biofuel policy or regulations in force, in which biofuel must meet GHG reduction requirements across its life cycle to comply with such policy or regulations and/or to qualify for certain initiatives, biofuel operations subject to such policy or regulations shall comply with such policy and regulations and/or qualify for the applicable incentives.

- Criterion 3b: Life-cycle GHG emissions of biofuel shall be calculated using the RSB lifecycle GHG emission calculation methodology, which incorporates methodological elements and input data from authoritative sources; is based on sound and accepted science; is updated periodically as new data become available; has system boundaries from Well to Wheel; includes GHG emissions from land use change, including, but not limited to above- and below-ground carbon stock changes; and incentivizes the use of coproducts, residues and waste in such a way that the life-cycle GHG emissions of the biofuel are reduced.

- Criterion 3c: Biofuel blends shall have on average 50\% lower life-cycle GHG emissions relative to the fossil fuel baseline. Each biofuel in the blend shall have lower life-cycle GHG emissions than the fossil fuel baseline.

Principle 4. Biofuel operations shall not violate human rights or labor rights, and shall promote decent work and the well-being of workers.

- Criterion 4a: Workers shall enjoy freedom of association, the right to organize, and the right to collectively bargain.

- Criterion 4b: No slave labor or forced labor shall occur.

- Criterion 4c: No child labor shall occur, except on family farms and then only when work does not interfere with the child's schooling and does not put his or her health at risk.

- Criterion 4d: Workers shall be free of discrimination of any kind, whether in employment or opportunity, with respect to gender, wages, working conditions and social benefits.

- Criterion 4e: Workers' wages and working conditions shall respect all applicable laws and international conventions, as well as all relevant collective agreements. Where a government regulated minimum wage is in place in a given country and applies to the specific industry sector, this shall be observed. Where a minimum wage is absent, the wage paid for a particular activity shall 
be negotiated and agreed on an annual basis with the worker. Men and women shall receive equal remuneration for work of equal value.

- Criterion 4f: Conditions of occupational safety and health for workers shall follow internationally recognized standards.

- Criterion 4g: Operators shall implement a mechanism to ensure the human rights and labor rights outlined in this principle apply equally when labor is contracted through third parties.

Principle 5. In regions of poverty, biofuel operations shall contribute to the social and economic development of land, rural and indigenous people and communities.

- Criterion 5a: In regions of poverty, the socioeconomic status of local stakeholders impacted by biofuel operations shall be improved.

- Criterion 5b: In regions of poverty, special measures that benefit and encourage the participation of women, youth, indigenous communities and the vulnerable in biofuel operations shall be designed and implemented.

Principle 6. Biofuel operations shall ensure the human right to adequate food and improve food security in food insecure regions.

- Criterion 6a: Biofuel operations shall assess risks to food security in the region and locality and shall mitigate any negative impacts that result from biofuel operations.

- Criterion 6b: In food insecure regions, biofuel operations shall enhance the local food security of the directly affected stakeholders.

Principle 7. Biofuel operations shall avoid negative impacts on biodiversity, ecosystems and conservation values.

- Criterion 7a: Conservation values of local, regional or global importance within the potential or existing area of operation shall be maintained or enhanced.

- Criterion 7b: Ecosystem functions and services that are directly affected by biofuel operations shall be maintained or enhanced.

- Criterion 7c: Biofuel operations shall protect, restore or create buffer zones.

- Criterion 7d: Ecological corridors shall be protected, restored or created to minimize fragmentation of habitats
- Criterion 7e: Biofuel operations shall prevent invasive species from invading areas outside the operation site.

Principle 8. Biofuel operations shall implement practices that seek to reverse soil degradation and/or maintain soil health.

- Criterion 8a: Operators shall implement practices to maintain or enhance soil physical, chemical and biological conditions.

Principle 9. Biofuel operations shall maintain or enhance the quality and quantity of surface and ground water resources, and respect prior formal or customary water rights.

- Criterion 9a: Biofuel operations shall respect the existing water rights of local and indigenous communities.

- Criterion 9b: Biofuel operations shall include a water management plan which aims to use water efficiently and to maintain or enhance the quality of the water resources that are used for biofuel operations.

- Criterion 9c: Biofuel operations shall not contribute to the depletion of surface or groundwater resources beyond replenishment capacities.

- Criterion 9d: Biofuel operations shall contribute to the enhancement or maintaining of the quality of the surface and groundwater resources.

Principle 10. Air pollution from biofuel operations shall be maintained along the supply chain.

- Criterion 10a: Air pollution emission sources from biofuel operations shall be identified, and air pollutant emissions minimized through an air management plan.

- Criterion 10b: Biofuel operations shall avoid and, where possible, eliminate open-air burning of residues, wastes or by-products, or open air burning to clear land.

Principle 11. The use of technologies in biofuel operations shall be fully available, unless limited by national law or international agreements on intellectual property.

- Criterion 11a: Information on the use of technologies in biofuel operations shall be fully available, unless limited by national law or international agreements on intellectual property.

- Criterion 11b: The technologies used in biofuel operations including genetically modified: 
plants, micro-organisms and algae, shall minimize the risk of damages to environment and people, and improve environmental and/or social performance over the long term.

- Criterion 11c: Micro-organisms used in biofuel operations which may represent a risk to the environment or people shall be adequately contained to prevent release into the environment.

- Criterion 11d: Good practices shall be implemented for the storage, handling, use, and disposal of biofuels and chemicals.

- Criterion 11e: Residues, wastes and by-products from feedstock processing and biofuel production units shall be managed such that soil, water and air physical, chemical and biological conditions are not damaged.

Principle 12. Biofuel operations shall respect land rights and land use rights.

- Criterion 12a: Existing land rights and land use rights, both formal and informal, shall be assessed, documented, and established. The right to use land for biofuel operations shall be established only when these rights are determined.

- Criterion 12b: Free, prior and informed consent shall form the basis for all negotiated agreements for any compensation, acquisition, or voluntary relinquishment of rights by land users or owners for biofuel operations. 

CIFOR Working Papers contain preliminary or advance research results on tropical forest issues that need to be published in a timely manner to inform and promote discussion. This content has been internally reviewed but has not undergone external peer review.

Indonesia's forests make up one of the world's most biologically diverse ecosystems. They have long been harvested by local people to meet their daily needs. Since the 1970s, a combination of demographic, economic and policy factors has driven forest exploitation at the industrial scale and resulted in growing deforestation. Key factors behind the forest loss and land use change in present-day Indonesia are the expansion of oil palm, plywood production and pulp and paper industries. Oil palm has been one of the fastest-growing sectors of the Indonesian economy, increasing from less than 1 million hectares in 1991 to 8.9 million hectares in 2011. The plywood and pulp and paper industries have also expanded significantly since the log export ban in 1985. All three sectors have contributed to deforestation. Several measures are being taken to reduce the loss of tropical forests in Indonesia. These measures are driven by growing global concern about the impact of deforestation on biodiversity and global warming and the Indonesian government's commitment to reduce greenhouse gas emissions. A major policy initiative revolves around developing renewable energy from biomass that can be sourced from oil palm, sugar, cassava, jatropha and timber plantations. This paper analyzes these measures and assesses the conditions under which they may be most effective.

Fund

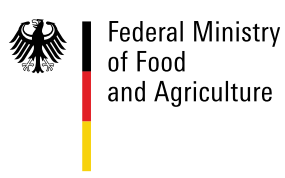

CGIAR 